\title{
f 1163
}

\section{Alloy Development for Irradiation Performance}

Quarterly Progress Report For Period Ending September 30, 1980 U.S. Department of Energy Office of Fusion Energy 


\section{DISCLAIMER}

This report was prepared as an account of work sponsored by an agency of the United States Government. Neither the United States Government nor any agency Thereof, nor any of their employees, makes any warranty, express or implied, or assumes any legal liability or responsibility for the accuracy, completeness, or usefulness of any information, apparatus, product, or process disclosed, or represents that its use would not infringe privately owned rights. Reference herein to any specific commercial product, process, or service by trade name, trademark, manufacturer, or otherwise does not necessarily constitute or imply its endorsement, recommendation, or favoring by the United States Government or any agency thereof. The views and opinions of authors expressed herein do not necessarily state or reflect those of the United States Government or any agency thereof. 


\section{DISCLAIMER}

Portions of this document may be illegible in electronic image products. Images are produced from the best available original document. 


\section{Printed in the United States of America. Available from National Technical Information Service U.S. Department of Commerce 5285 Port Royal Road, Springfield, Virginia 22161 NTIS price codes-Printed Copy: A11 Microfiche A01}

This report was prepared as an account of work sponsored by an agency of the United States Government. Neither the United States Government nor any agency thereof, nor any of their employees, makes any warranty, express or implied, or assumes any legal liability or responsibility for the accuracy, completeness, or usefulness of any information, apparatus, product, or process disclosed, or represents that its use would not infringe privately owned rights. Reference herein to any specific commercial product, process, or service by trade name, trademark, manufacturer, or otherwise, does not necessarily constitute or imply its endorsement, recommendation, or favoring by the United States Government or any agency thereof. The views and opinions of authors expressed herein do not necessarily state or reflect those of the United States Government or any agency thereof. 


\title{
ALLOY DEVELOPMENT FOR IRRADIATION PERFORMANCE QUARTERLY PROGRESS REPORT FOR PERIOD ENDING SEPTEMBER 30, 1980
}

\author{
ARGONNE NATIONAL LABORATORY \\ GENERAL ATOMIC COMPANY \\ HANFORD ENGINEERING DEVELOPMENT LABORATORY \\ MCDONNELL DOUGLAS ASTRONAUTICS COMPANY \\ MASSACHUSETTS INSTITUTE OF TECHNOLOGY \\ NAVAL RESEARCH LABORATORY \\ OAK RIDGE NATIONAL LABORATORY \\ SANDIA NATIONAL LABORATORIES \\ WESTINGHOUSE FUSION POWER SYSTEMS
}

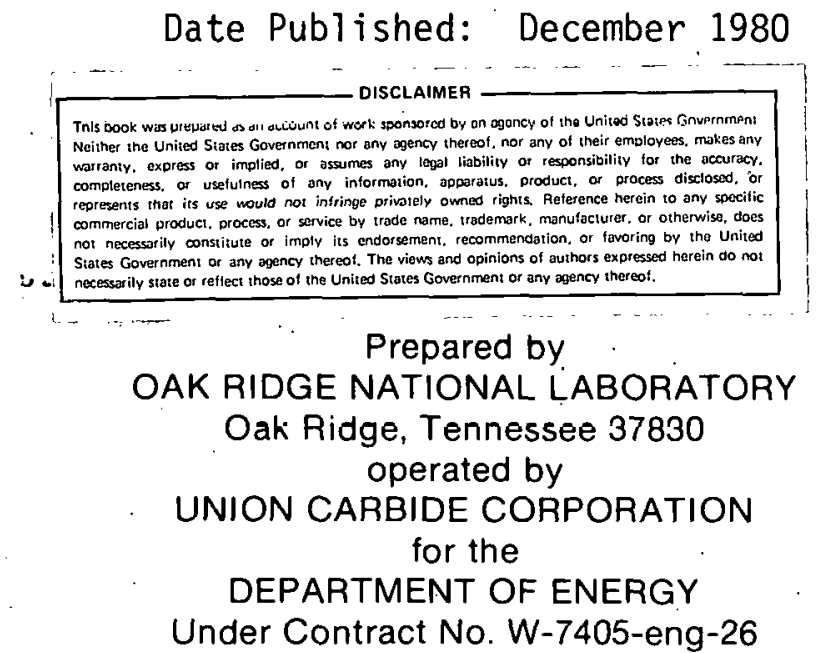




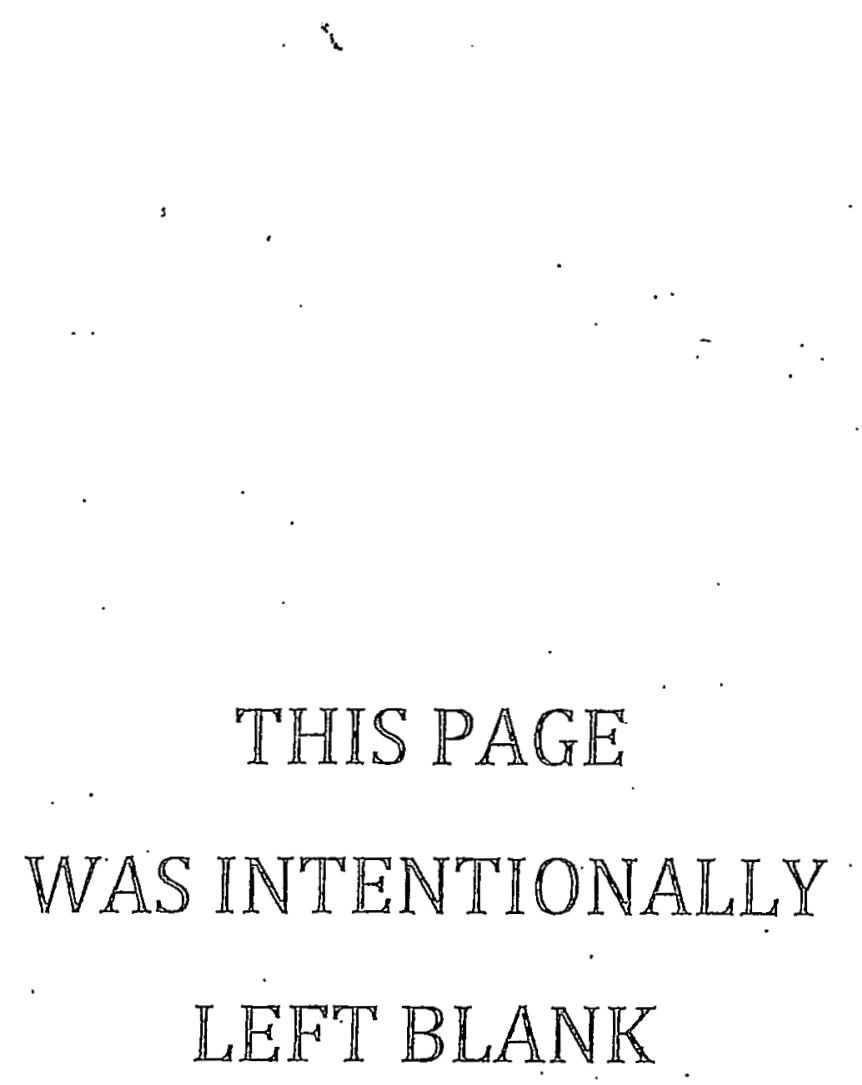


FOREWORD

This report is the tenth in a series of Quarterly Technical Progress Reports on "Alloy Development for Irradiation Performance" (ADIP), which is one element of the Fusion Reactor Materials Program, conducted in support of the Magnetic Fusion Energy Program of the U.S. Department of Energy. Other elements of the Materials Program are

- Damage Analysis and Fundamental Studies (DAFS)

- Plasma-Materials Interaction (PMI)

- Special-Purpose Materials (SPM)

The first seven reports in this series are numbered DOE/ET-0058/1 through 7. This report is the third in a new numbering sequence that begins with DOE/ER-0045/1.

The ADIP program element is a national effort composed of contributions from a number of National Laboratories and other government laboratories, universities, and industrial laboratories. It was organized by the Materials and Radiation Effects Branch, Office of Fusion Energy, DOE, and a Task Group on 4 ZZoy Development for Irradiation Performance, which operates under the auspices of that Branch. The purpose of this series of reports is to provide a working technical record of that effort for the use of the program participants, for the fusion energy prograin in general, and for the Department of Energy.

This report is organized along topical lines in parallel to a Program Plan of the same title so that activities and accomplishments may be followed readily relative to that Program Plan. Thus, the work of a given laboratory may appear throughout the report. Chapters 1, 2, 8 , and 9 review activities on analysis and evaluation, test methods development, status of irradiation experiments, and corrosion testing and hydrogen permeation studies, respectively. These activities relate to each of the alloy development paths. Chapters $3,4,5,6$, and 7 present the ongoing work on each alloy development path. The Table of contents is annotated fui the convenience of the reader.

This report has been compiled and edited under the guidance of the Chairman of the Task Group on AlZoy Development for Irradiation Performance. E. E. Bloom, Oak Ridge National Laboratory, and his efforts and those of the supporting staff of ORNL and the many persons who made technical contributions are gratefully acknowledged. T. C. Reuther, Materials and Radiation Effects Branch, is the Department of Energy Counterpart to the Task Group Chairman and has responsibility for the ADIP Program within DOE.

Klaus M. Zwilsky, Chief Materials and Radiation Effects Branch office of Fusion Energy 
THIS PAGE

\section{WAS INTENTIONALLY}

LEFT BLANK 
CONTENTS

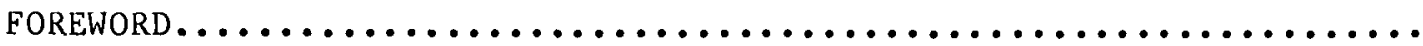

1. AnAlysis and evaluation studies $\ldots \ldots \ldots \ldots \ldots \ldots \ldots \ldots \ldots \ldots \ldots \ldots$

1.1 Materials Handbook for Fusion Energy Systems (McDonnell Douglas Astronautics Company and Hanford Engineering

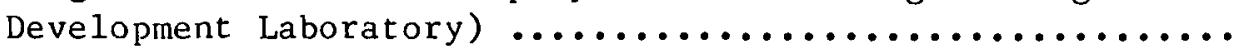

In mid-September a meeting was held by the austenitic stainless steel working group of ADIP. The purpose of this meeting was to review the prepared data sheets on $20 \% \mathrm{CW}$ type 316 stainless steel. The consensus of this group was that some minor modifications needed to be made prior to their release. The first of these data sheets which covers the effect of irradiation on the elevated temperature fatigue strength of $20 \%$ cold worked 316 stainless steel has been received by the MHFES and subsequently submitted to the Analysis and Evaluation task group for review and approval.

2. TEST HATRICES AND TEST METHODS DEVELOPHENT $\ldots \ldots \ldots \ldots \ldots \ldots \ldots$

2.1 Neutronic Calculations for the Conceptual Design of an In-Reactor Solid Breeder Experiment, TRIO-01 (Oak Ridge

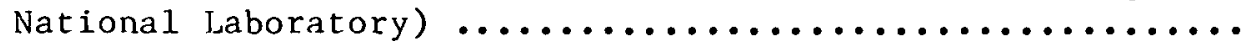

The cross sections that include the delayed fission gammas have been processed. Additional neutronic calculations using these cross sections have been carried out to determine the tritium production and heating rates within two fusion breeder materials, $\mathrm{Li}_{2} \mathrm{O}$ and $\mathrm{LiAlO}_{2}$. During the generation of the new cross-section set we detected an error in the thermal $23 b_{U}$ neutron cross section. correcting this error resulted in an increase in the tritium production and heating rates within the test assembly of about 30 and $10 \%$. respectively. for the $\mathrm{Li}_{2} \mathrm{O}$ breeder material.

Since the temperature gradient acroes the teet cell should be as small as possible, we have changed the original geometry. The original outer dimensions of the test cell have been reduced from 17.8 to 12.7 mon and the stainless steel can from 19.1 to $14.0 \mathrm{~mm}$. The aluminum core piecee inner matius liks redure.t. to $14.0 \mathrm{~mm}$ to filt. the void. Additional neutronic calculations using the above geronetry changes have been carried out to determine the changes in the tritium production and heating rates. The rates for the new geometric model are similar to those obtained for the original model. Preliminary bumup calculations of the $L i_{2} O$ breeder material indicate that one-half the ${ }^{6}{ }_{L i}$ will be consumed in about $70 \mathrm{~d}$ reactor operation. 
2.2 Neutronic Calculations in Support of the ORR-MFE-4A Spectral Tailoring Experiment (Oak Ridge National

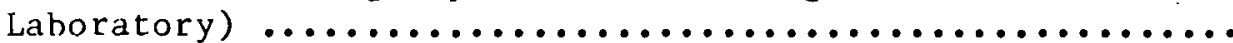

Three-dimensional neutronic calculations are being carried ont to follow the irradiation environment of the ORR-MFE-4A experiment. These calculations currently cover si $x$ ORR reactor cycles corresponding to $46,742 \mathrm{MW}$ hrs. This will result in a thermal fluence of $2.03 \times 10^{25}$ neutrons $/ \mathrm{m}^{2}$ and a total fluence of $4.31 \times 10^{25}$ neutrons $/ \mathrm{m}^{2}$. Thi.s fluence will produce 1.09 dpa and 3.31 at. ppm He in type 316 stainless steel (not including 2.0 at. ppm He from $10_{B}$ ). These data and previous calculations have been used to estimate the dates at which the core pieces should be changed and first. samples removed.

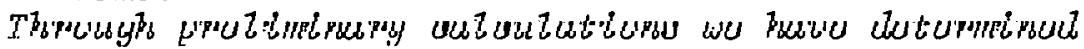
the approprtate staes of the tungsten core pleces as well as the heating rates within them and within the experimerlul cupsules. The reduction ir yumru heatirly resulting from the use of tungsten core pieces may require additional heating of the samples to maintain proper temperature. Calculations similar to those carried out for the tungsten core pieces are in progress for hafnium core pieces.

2.3 Operation of the ORR Spectral Tailoring Experiment ORR-MFL-4A (Oak Ridge National Laboratory) .............

This experiment consists of two test regions designed to irradiate type 316 stainless steel and Path A PCA at constant temperatures of 300 and $400^{\circ} \mathrm{C}$. The ORR-MEE-4A experiment was installed in the Oak Ridge Research Reactor (ORR) on e'uns 10, 1980, and as of Soptombor 30 has oporatod sucosesfully for an squivalont 99. d at $30 \mathrm{MW}$ roastor powor with maximum specimen temperatures in each region of 330 and $400^{\circ} \mathrm{C}$ respectively.

2.4 HFIR-MFE-T1, $-\mathrm{T} 2$, and -RB1: Experiments to Evaluate the Effects of Low-Temperature Irradiation on Ferritic Steels

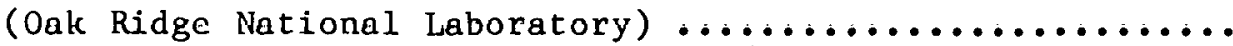

Three empriments for the irradiation of ferrittice steels in the HFIR have been outlined. All three experiments are to operate at about $50^{\circ} \mathrm{C}$. They will provide the first substantial data on the effects of helium and displacement production on several properties, including fatigue, tensile, Charpy impact, crack growth, and fracture toughness. The steels to be tested include $12 \mathrm{Cr}-1 \mathrm{MO}$ (HT9), nickel-doped $12 \mathrm{Cr}-1 \mathrm{MO}, 9 \mathrm{Cr}-1 \mathrm{MO}$, nickel-doped $9 \mathrm{Cr}-1 \mathrm{MO}, 2 \mathrm{1/4} \mathrm{Cr}-1 \mathrm{MO}$, and welds of some of these. Test results will complement elevated-temperature Experimental Breeder Reactor (EBR-II) irradiation experiments on the same alloys. Test matrices and fluence levels have been defined, and the experiments are expected to be ready for insertion in late 1980 or early 1981 . 
2.5 Experiments HFIR-CTK-30, -31 , and -32 for Irradiation of Transmission Electron Microscopy Disk Specimens (Oak Ridge

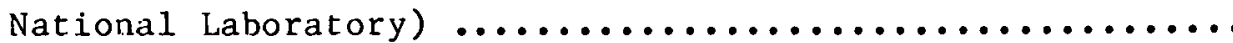

Three irradiation capsules containing exclusively transmission electron microscopy (TEM) disk specimens have been constructed for High Flux Isotope Reactor (HFIR) irradiation. Experiments HFIR-CTR-30 and -32 are now being irradiated, and HFIR-CTR-31 is scheduled for insertion on October 1, 1980. All capsules are being irradiated in peripheral target positions in the HFIR. The 12 groups of approximately 100 specimens each are arrayed along the capsule axis of each experiment. Each group is designed to be isothermal at an elevated temperature determined by a helium gas gap. Irradiation temperatures of 300, 400, 500 , and $600^{\circ} \mathrm{C}$ have been selected.

2.6 Measurements of the Fatigue Pre-Cracked Length of Fracture Toughness Specimens Using an Electropotential Technique (Hanford Engineering Development Laboratory) ............

HT-9 fracture toughness specimens were fatigue precracked using an electropotential technique to monitor the precrack length. A calibration curve was developed from optical crack measurements. Test results produced by this technique are shown to be as accurate as these obtained by optical methods. The technique will be used in the hot-cell to replace the tedious optical method.

2.7 Status of MFE-5 In-Reactor Fatigue Crack Growth Experiment (Hanford Engineering Development Laboratory) ............

Fabrication of the in-reactor fatigue machine to be used in MFE-5 is completed. The assembly has been delivered to ORNL as final preparations are underway for a November insertion. Modification of the prototypic fatigue machine, to be used in the thermal control test at HEDL, is in progress.

2.8 Specimen Matrix for the HFIR Irradiation of the Path $B$ Alloys (Hanford Engineering Development Laboratory) .......

specimens of the path $B$ alloys, in the form of TEM disks, have been included in the HFIR experiments designated HFIR-CTR-30, 31, and 32. These irradiations will provide the first data on the irradiation response of the path $B$ base researih alloys.

3. PATH A ALLOY DEVELOPHENT - AUSTENITIC STAINLESS STEELS ........

3.1 High-Temperature Fatigue Crack Propagation Testing of Type 316 Stainless Steel in Vacuum (Naval Research Laboratory) .................................

Lost in transit. 
3.2 Miniature Tensile Testing of 316 Stainless Steel (Hanford Engineering Development Laboratory) $\ldots \ldots \ldots \ldots \ldots \ldots \ldots \ldots$

Extensive tensile testing has been performed on two conditions of 316 SS to demonstrate the viability of this technology. Results from this baseline testing agree with published values in the literature. Miniature tensile specimens fabricated from $3165 S$ have been irradiated at RTNS-II and exhibit evidence of irradiation hardening at the peak fluence of $1.1 \times 10^{18} \mathrm{n} / \mathrm{cm}^{2}$.

3.3 The Effect of Annealing Temperature on the Grain Size of the Path A Prime Candidate Alloy (Oak Ridge National

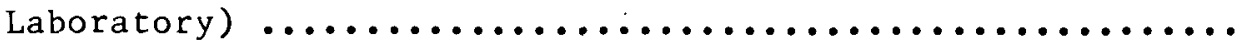

Troserving homogene.ily in Lhe PCA ulloy duming fabrication demands solution treatment in the range 1150 to $1175^{\circ} \mathrm{C}$. These temperatures result in grain si.res ranging from ASTM 1 to 4 . Often, however, a finer grain size is required. Therefore, litis study sought to decouplie. the final in-process anneal from the thermal-mechanical treatments to develop MC precipitate microstructures. Rapid to relatively slow heating rates and cold-work levels of 30 to $50 \%$ were used to recrystallize the material without precipitating appreciable MC or losing the homogeneity. The grain size was then simply a function of the annealing temperature. A grain size control anneal of $1100^{\circ} \mathrm{C}$ was selected to produce an intermediate grain size of ASTM 4 to 7. This allows the program to separate grain size and preirradiation microstructure effects on properties.

4. PATH B ALLOY DEVELOPIENT - HIGHER STRENGTH Fe-Ni-Cr ALLOYS .... No contributions.

5. PATH C ALLOY DEVELOPMENT - REACTIVE AND REFRACTORY ALLOYS .....

5.1 Tensile Properties and Microstructure of Helium-Injected and Reactor-Irradiated $\mathrm{V}-20 \% \mathrm{Ti}$ (Oak Kidge National

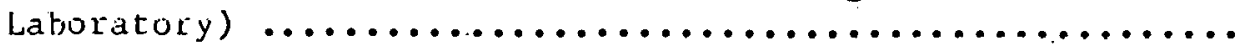

Sheet tensile samples of $V-20 \%$ Ti preinjected with 90 and 200 at. ppm He have been irradiated to about 20 dpa in the Exerimental Breeder Feactor (EBR-II) in the range 400 to $700^{\circ} \mathrm{C}$. Meohanical properties and mirenostmucture of tho irradiated specimen have been compared with those of control specimens. Helium embrittlement of $\mathrm{V}-20 \% \mathrm{Ti}$ becomes appreciable above test temperatures of $575^{\circ} \mathrm{C}$. Neutron irradiation enhanced the embrittlement of the helium-injected $\mathrm{V}-20 \% \mathrm{Ti}$. Helium injection also ussisted cavity formation in the reactor-irradiated $V-20 \% \mathrm{Ti}$. The size and concentration of cavities depended on the amount of injected helium. 
5.2 Fatigue Behavior of Unirradiated $\mathrm{V}-15 \% \mathrm{Cr}-5 \% \mathrm{Ti}$ (Oak Ridge

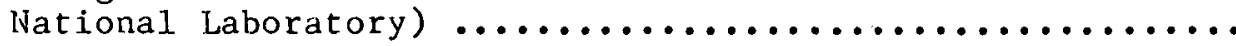

Eully reversed cyclic fatigue tests conducted on $V-15 \% \mathrm{Cr}-5 \%$ Ti (ADIP heat CAM-835 B-3) in the unirradiated condition at 25,550 , and $650^{\circ} \mathrm{C}$ indicated an apparent endurance limit at total strain ranges of about 0.7 and $0.6 \%$ at 550 and $650^{\circ} \mathrm{C}$, respectively.

5.3 The Effect of Hydrogen on Flaw Growth of Titanium Alloy Ti-6242S (McDonne11 Douglas Astronautics Company) ........

Initial fatigue crack growth rate tests. have been conducted at room and elevated temperatures with environment hydrogen pressures from 0 to $100 \mathrm{~Pa}(0.75$ torr) on Ti-6242S samples containing 50 and 500 wppm internal. hydrogen. These tests indicate that at room temperature there is an increase in the crack growth rate with the 500 wppm hydrogen content; no effect of environment hydrogen pressure was noted. Tests conducted at elevated temperatures indicate a decrease in crack growth rate with higher temperatures.

6. PATH D ALLOY DEVELOPIIENT - INNOVATIVE IIATERIAL CONCEPTS ......

6.1 The Effect of 4-MeV Nickel Ion Irradiation on the Microstructure of ( $\mathrm{Fe}, \mathrm{Ni})_{3} \mathrm{~V}$ Long-Range-Ordered Alloys

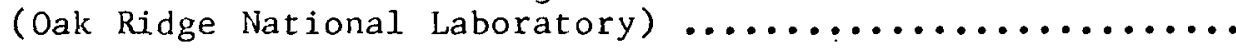

The (Fe, $\mathrm{Ni})_{3} \mathrm{~V}$ LRO alloys investigated are relatively resistant to swelling when irradiated with $4 \mathrm{HeV}(0.64-\mathrm{pJ})$ nickel ions to 70 dpa in the range 525 to $680^{\circ} \mathrm{C}$ and simultaneously injected with 8 at. ppm He and 28 at. ppm $D$ per dpa. Small titanium additions appear to improve the resistance to swelling, but it is not certain whether this effect depends strictiy on titanium or is related to the removal of sigma phase from the microstructure. AlZ the $L R O$ alloys retained their order for irradiation temperatures helow the critical ordering temperature of about $670^{\circ} \mathrm{C}$. However, long range order in itself did not appear to be the dominant factor determining swelling resistance.

7. PATH E ALLOY DEVELOPLIENT - FERRITIC STEELS ...............

7.1 Characterization of Fusion-Ferritic Steel Program $12 \mathrm{Cr}$ Heat and Metallurgical Studies on $12 \mathrm{Cr}-1$ Mo Steel

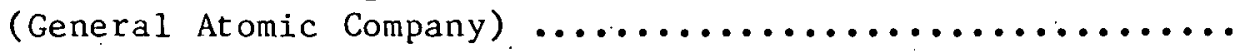

No contribution this quarter.

7.2 Fracture Toughness Testing of Alloy HT-9 (Naval Research

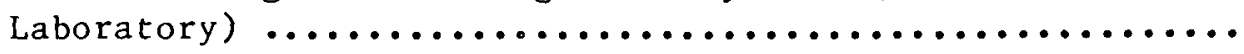

Lost in transit. 
7.3 Analysis of Laser Welds in HT9 (Sandia National

Laboratories ) .................................

Laser welds were made in $6.35 \mathrm{~mm}(0.25$ in) HT9 plate using a variety of travel speed/focal length combinations at a constant laser power level of $6 \mathrm{~kW}$. Welds performed at sharp focus with weld travel speeds ranging from 1.27 to $4.23 \mathrm{~mm} / \mathrm{sec}$ exhibited scattered porosity and occasional centerline cracking. Defocusing the laser beam relative to the plate resulted in welds containing severe porosity and centerline cracks. Microstmuctural and microhardness evaluation of the welds indicated that the region of highest hardness occurred in the heat-affected zone immediately adjacent to the fusion line. A mechanism for oonterline cratking in libib alloy has been proposed.

7.4 Environmental Effects on Properties of Ferritic Steels

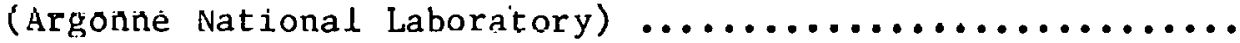

Several continuma-cycle fatiguo tosto have been conducted with 2.5-mm-diameter specimens of HT-.9 alloy at $755 \mathrm{~K}$ in flowing lithium. The results indicate a strong effect of corrosion on the fatigue life of HT-9 alloy in a liquid lithium environment. At a total strain range of $0.5 \%$, the fatigue life in lithium is a frotor of $\sim 5$ lower than that in a liquid sodium environment. The specimens tested in lithium show intergranular cracks along the entire gauge length. Fatigue tests at different strain rates and strain sequence are being conducted to establish the important parameters, viz.. stress/strain range, frequency, iithium purity, etr. Exposure of corrosion specimens of H'T-9 alloy, Type 316 stainless steel, and Inconel 625 with solid $\mathrm{Li}_{2} \mathrm{O}, \mathrm{LiAlO}_{2}$, and $\mathrm{Li}_{2} \mathrm{SiO}_{3}$ breeding materials at $873 \mathrm{~K}$ has been completed. Metallographic evaluation of the specimens is in progress. Preliminary results indicate that lithium oxide is the most reactive of the three breeding materials.

7.5 Calculations of Hydrogen Isotope Loading in HT9 First Wall Structures (Sandia Narional Laboratories) ..............

Calculations of the hydrogon lavol in finst wril. urbl blanket structures have been made using HTS as the material of constmution. Both directily injected deutervium and tritium profiles and. hijdrogen profilos from $(n, p)$ mexetions have been calculated over a temperature range from 473 to $638 \mathrm{~K}$. Two boundary conditions have been assumed: zero surface concentration and a concentration set by the surface recombination reaction of hydrogen ions to form hydrogen moleoules. Tho rooults indicate thal uruler the most severe conditions, peak hydrogen levels will not exeed 0.5 appm and will likely be far lower. 
8. STATUS OF IRRADIATION EXPERIMENTS AND ILATERIALS INVENTORY .....

8.1 Irradiation Experiment Status and Schedule .............

The following bar charts show the schedule for all ADIP reactor irradiation experiments. Experiments are presently under way in the Oak Ridge Research Reactor (ORR) and the High Flux Isotope Reactor (HFIR), which are mixed spectrum reactors, and in the Experimental Breeder Reactor (EBR-II), which is a fast reactor.

8.2 ETM Research Materials Inventory (Oak Ridge National Laboratory and McDonnell Douglas Astronautics Company) ....

The Office of Fusion Energy has assigned program responsibility to ORNL for the establishment and operation of a central inventory of research materials to be used in the Fusion Reactor Materials research and development programs. The objective is to provide a common supply of material for the Fusion Reactor Materials Program. This will minimize umintended materials variables and provide for economy in procurement and for centralized recordkeeping. Initially this inventory will focus on materials related to first-wall and stmuctural applications and related research, but various special purpose materials may be added in the future.

9. MATERIALS COMPATIBILITY AND hYDROGEN PERMEATION STUdIES $\ldots . . \ldots$

9.1 Hydrogen Dissolution and Permeation Studies of ADIP Program

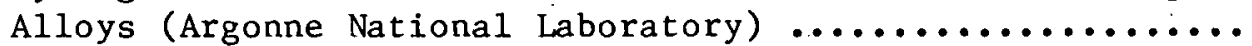

Studies of the hydrogen permeation characteristics of iron base (Path E) alloys have continued. An investigation of a $\mathrm{Cr}$ 14-AI 0.2 steel (405-SS) was completed and the measurements were compared to provious data for three other $\mathrm{Fe}-\mathrm{Cr}$ alloys having $\mathrm{O}, 2$, and $5 \mathrm{wt. \%} \mathrm{Al}$, respectively. The combined results indicate that the optimum aluminum content leading to minimum hydrogen permeability in a reducing environment is around 3 wt. $\%$. Howovar, tho ohromium content of alloys studied to date has only spanned the range from 14 to $18 \mathrm{wt. \%}$, and the location of an optimum at 2 wt.\% aluminum may not necessarily apply to other types of Path $E$ alloys.

9.2 Vanadium Alloy/Lithium Pumped-Loop Studies (Argonne

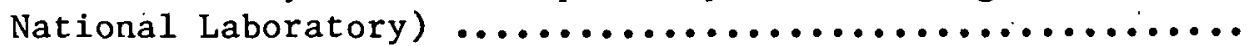

The stainless-steel-clad/V-15 Cr lithium loop has now operated for over $12,000 \mathrm{~h}$ and exposures of selected refractory alloys have continued. The DOE/Office of Fusion Energy guidance on this project for $F Y-1981$ has been to defer effort to solid breeder material development activities. The work presently in progress is being completed and a final reporting of results will be made in a subsequent ADIP progress report. 
9.3 Compatibility of Static Lithium with $\mathrm{Fe}-\mathrm{Ni}-\mathrm{V}$ and $\mathrm{Fe}-\mathrm{Cr}-\mathrm{Mo}$

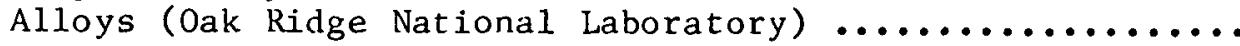

Specimens of $21 / 4 \mathrm{Cr}-1 \mathrm{HO}$ steel, HT9, and the longrange-ordered (LRO) alloy Fe-31.8 Ni-22.5 V-0.4 Ti (wt \%) were tested in static lithium. Carbon analysis of the lithium after 3000-h tests of $21 / 4 \mathrm{Cr}-1 \mathrm{MO}$ steel showed significant decarburization of the steel at 500 and $600^{\circ} \mathrm{C}$. The decarburization lovered the room temperature tensile strength of the alloy. Specimens of $21 / 4 \mathrm{Cr}-1 \mathrm{MO}$ steel exposed to $L i-5$ wt \% Al showed significant weight gains with an accompanying decrease in ductility. Also, the gage section of fractured tensile specimens contained a significant volume of cracks. Short-term (500-h) exposures of HT9 to static $500^{\circ} \mathrm{C}$ lithium resulted in negligible weight changes and no change in its tensile properties relative to specimens exposed to argon under othervise similar conditions. Surface depasit.s on the corrosion-resistant taRO alloy after exposure to lithium at 650 and $710^{\circ} \mathrm{C}$ for $2000 \mathrm{~h}$ were pure variadium or possibly a vanadium carbonitride.

9.4 Mass Transfer of Type 316 Stainless Steel in Lithium Thermal-Convection Loops (Oak Ridge National Laboratory) ..

The time dependence of metal dissolution in five type 316 stainlese steel loop experiments in lithium is discussed. In general, the five sets of measurements were satisfactorily reproducible. The predicted dissolution rate of type 316 stainless steel at $600^{\circ} \mathrm{C}$ in lithium under conditions typical of semistagnant tritium-breeding blankats is loes than $13 \mathrm{jm} /$ yoar $(0.5 \mathrm{mil} / \mathrm{year})$.

9.5 Compatibility of Solid Ceramic Breeder Materials with ADIP Prograin Alloys (Argonne National Laboratory) ............

An initial scoping experiment was carried out to investigate the interfacial compatibility of selected solid ceramic tritium breeder materials with typical ADIP Program alloys. Each of the solid breeder materials $\mathrm{Li}_{2} \mathrm{O}, \mathrm{LiAlO}_{2}$, and $\mathrm{Li}_{2} \mathrm{SiO}_{3}$ was exposed to 316-SS, HT-9, Incone 2 625, and Ti6848 at $873 \mathrm{~K}$ for $-1900 \mathrm{~h}$ in a high pupity holium environment using a reaction couple method. Examination of the alloy/ceramic interfaces by SEM, Auger, and X-ray diffraction analysis revealed that reaction scales comprised of elements from both the alloy and ceramic had formed in all ases. Thess sualos wore thiskest for the $\mathrm{Li}_{2} \mathrm{O} / \mathrm{all}$ y reaction couples. Temary phases of the type $\mathrm{Li}_{\mathrm{M}} \mathrm{O}_{z}$ have been identified at most of the interfaces for which analyses have been completed. Analytical procedures and improved strategies for future ceramic breeder corrosion tests have been developed. 
1. ANALYSis AND EVALUATION STUdies 
1.1 MATERIALS HANDBOOK FOR FUSION ENERGY SYSTEMS - J. W. Davis (McDonne11 Douglas Astronautics Company - St. Louis) and T. K. Bierlein (Hanford Engineering Development Laboratory)

\subsubsection{ADIP Task}

Task Number 1.A.1 - Define material property requirements and make structural life predictions.

\section{1 .2 Objective}

To provide an authoritative and consistent source of material property data for use by the fusion energy community in concept evaluation design, safety analysis, and performance/verification.

\section{1 .3 Summary}

In mid-September a meeting was held by the austenitic stainless steel working group of ADIP. The purpose of this meeting was to review the prepared data sheets on $20 \% \mathrm{CW}$ type 316 stainless steel. The consensus of this group was that some minor modifications needed to be made prior to their release. The first of these data sheets which covers the effect of irradiation on the elevated temperature fatigue strength of $20 \%$ cold worked 316 stainless steel has been received by the MHFES and subsequently submitted to the Analysis and Evaluation task group for review and approval.

\subsubsection{Progress and Status}

The Materials Handbook for Fusion Energy System is designed to meet the near term and tuture data needs of the fusion energy community. Since its creation last year, the handbook.has prompted considerable interest in the design community with the net result that there have been a number of requests by individuals to be included in the distribution. Currently we have distributed over 70 copies to 30 different organizations, consisting of national laboratories, universities and industry. The initial focus of the handbook has been to supply data sheets on the first wall structural materials and in particular type 316 stainless steel in support of ETF (now called FED). Because of the emphasis on structural materials, the 
handbook was made part of the Analysis and Evaluation Subtask group of ADIP. During the course of the year a number of requests were received from various design projects (e.g., Starfire, FED, and MFTF) seeking information and data on a variety of materials outside the first. wall and blanket region. Since, in some cases, the data requirements for FED and other systems (MFTF and Starfire), were broader than the expertise currently available in ADIP, additional assistance was needed to prepare data sheets: from other Task groups and from experts outside the Task group structure. As a result it was decided by OFE to elevate the Analysis and Evaluation sub-Task group to a Task group. The relationship of the Materials handbook to the Analysis and Evaluation Task group and the other Task groups is shown in Figure 1.1.1. The members of the Analysis and Evaluation Task group are J. J. Holmes (HEDL), who is the Chairman, W. Bauer (Sandia), R. Chianese (W-FPS), F. W. Clinard (LASL), B. A. Cramer (MDAC, ETF), J. W. Davis (MDAC), D. G. Doran (HEDL), R. E. Ny.gren (HEDL, ETF), N. Simon; (NBS), and T. C. Reuther (DOE). Two additional members, one from ANL and the other from G.A. will be added at a later date. The members of the Analysis and Evaluation Task group will be responsible for establishing priority and scheule for the preparation of data sheets, review data sheets prior to publication and to approve the handbook methods and procedures. The relationship of the MHFES to the Analysis and Evaluation Task group along with the program flow of data sheets is shown in Figure 1.1.2.

There are essentially three methods that will be used to develop handbook data sheets. The first, which will be the approach most frequently used, is where the projects such as FED, MFTFB, or DEMO communicate their data needs to the Analysis and Evaluation Task group. The A\&E Task group will then review these data needs, establish priorities based on the project needs and communicate the needs and schedule to the MHFES. The MHFES will then examine these data needs and request the appropriate Task to take lead in preparing the data sheets. This approach was used in requesting the austenitic stainless steel working group of ADIP to prepare data sheets on type 316 stainless steel for the FED (ETF) project. If expertise for the preparation of the data sheets does not reside within the Task group structure (ADIP, DAFS, PMI, or SPM) then a member of A\&E will be asked to take the lead in preparing the data sheets. 


\section{FIGURE 1.1.1 ORGANIZATIONAL RELATIONSHIP OF MHFES TO DOE}

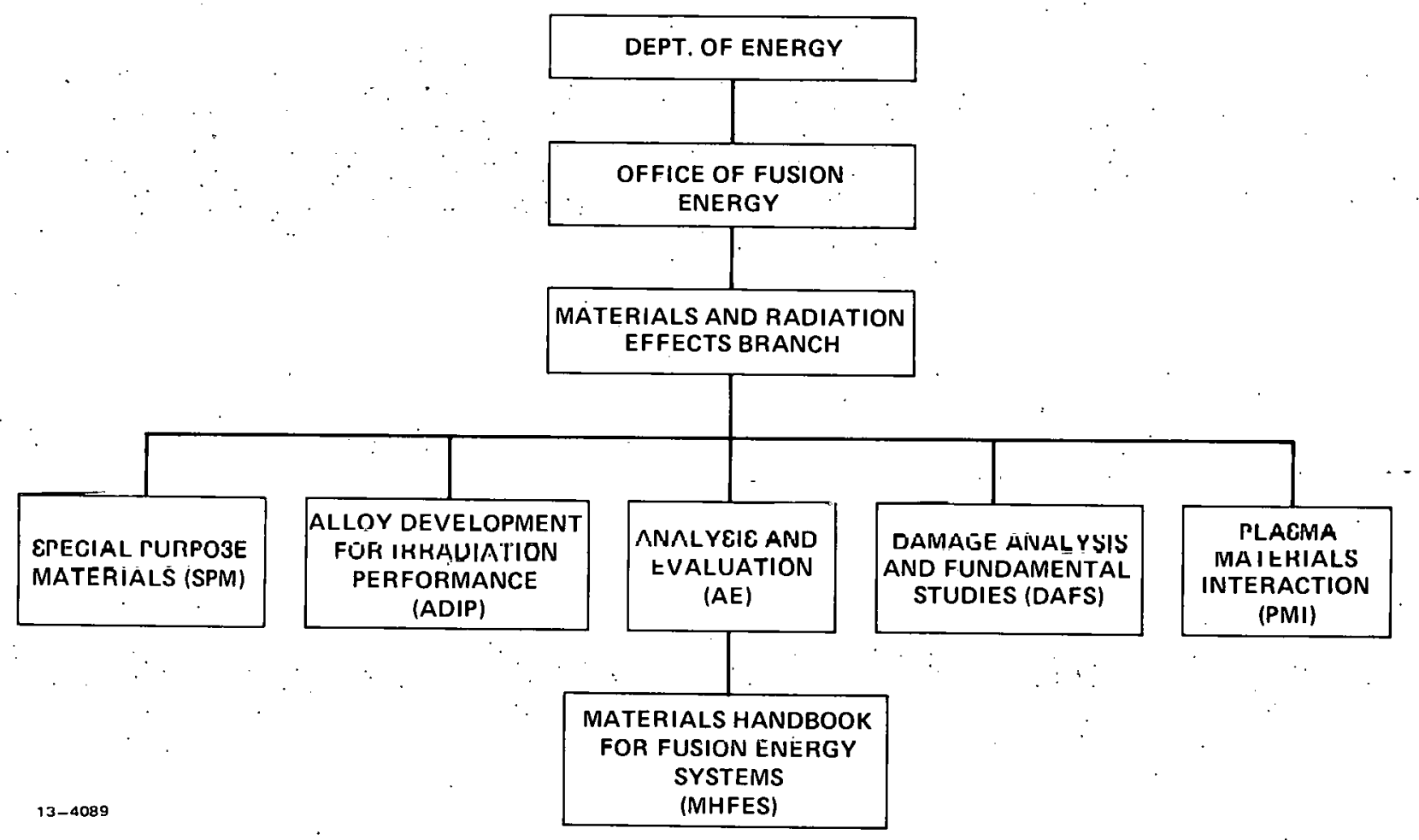

\section{FIGURE 1.1.2 MHFES - FUNCTIONAL ORGANIZATION}

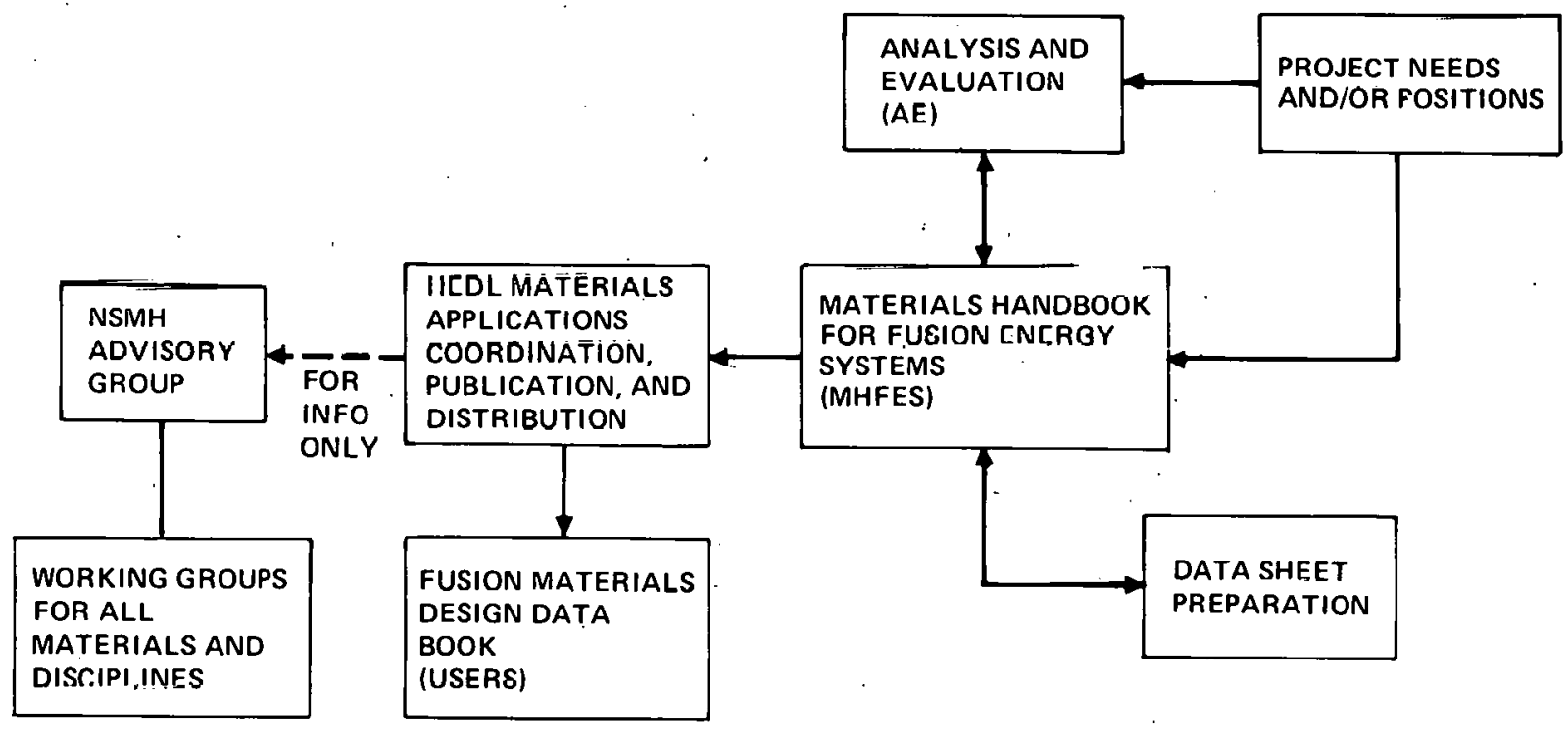


An example of this would be the need for information on superconducting magnet materials. Since the National Bureau of Standards has a large. volume of data, it would be more efficient to have Nancy Simons of NBS take the lead in preparing these data sheets.

The second method is essentially to use the same approach outlined in the first method but in cases where the projects are uncertain of their. data needs because the design is in a state of flux, the A\&E Task group will try to anticipate their future data requirements and have the appropriate data sheets prepared and available prior to the time the project would need them.

The third method will be used to cover emergency situations in which the design group requires the data faster than the handbook can respond. In this case the project materials representative would have to take the responsibility for preparing the data sheets. This data is still of value to the handbook and can be included in the MHFES provided it is prepared in a format compatible with the handbook and contains all the appropriate supporting documentation.

In all cases the prepared data sheets will be submitted by the MHFES handbook coordinator to the A\&E Task group for fianl review and approval. In this capacity the Task group will function much like the advisory group of the NSMH. The review will be accomplished by ballot and the review allowed two weeks to respond. Ballots not returned will be assumed to be affirmative notes. All disapprovals.will be resolved for general distribution and inclusion in the handbook.

Current1y the prinary fucus of the handbook is the preparation of data sheets on $20 \%$ cold worked type 316 stainless steel by the austenitic stainless steel working group of ADIP. A meeting was held in mid-September by this working group at ORNL to review the data sheets prior to submittal to the MHFES for final review. The consensus of the members of the group was that some minor modifications needed to be made to the data sheets prior to this release. It was tentatively agreed that one month would be necessary to make these changes after which time the sheets would be ready for review by the A\&E Task group. The first of these data sheets, which was prepared by M. L. Grossbeck of ORNL, covers the effect of irradiation 
on the elevated temperature fatigue strength of $20 \% \mathrm{CW}-316$ stainless stee1, has been received and has been submitted for review. The balance of the data sheets should be received in the near future. 
2. TEST MATRICES AND TEST METHODS DEVELOPIENT 
2.1 NEUTRONIC CALCULATIONS FOR THE CONCEPTUAL DESIGN OF AN IN-REACTOR

SOLID BREEDER EXPERIMENT, TRIO-01 - T. A. Gabriel, R. A. Lillie, and R. L: Childs (ORNL)

\section{1 .1 ADIP Task}

ADIP Task I.A.2, Define Test Matrices and Test Procedures.

\subsubsection{Objective}

The objective of these neutronic calculations is to provide tritium production and heat generation rates for the irradiation of solid tritium breeding materials in the Oak Ridge Research Reactor (ORR). These calculations will guide the design of the reactor irradiation experiment.

\section{1 .3 Summary}

The cross sections that include the delayed fission gammas have been processed. Additional neutronic calculations using these cross sections have been carried out to determine the tritium production and heating rates within two fusion breeder materials, $\mathrm{Li}_{2} \mathrm{O}$ and $\mathrm{LiAl}, \mathrm{O}_{2}$. During the generation of the new cross-section set we detected an error in the thermal $235 \mathrm{U}$ neutron cross section. Correcting this error resulted in an increase in the tritium production and heating rates within the test assembly of about 30 and $10 \%$, respectively, for Llie $\mathrm{LL}_{2} \mathrm{O}$ breeder material.

Sincc the temperature gradient across the test cell shnuld he as small as possible, we have changed the original geometry. The original outer dimensions of the test cell have been reduced from 17.8 to $12.7 \mathrm{~mm}$ and the stainless steel can from 19.1 to $14.0 \mathrm{~mm}$. The aluminum core piece Inner radlus was reduced to $14.0 \mathrm{~mm}$ to fill the void. Additional neutronic calculations using the above geometry changes have been carried out to determine the changes in the tritium production and hcating rates. The rates for the new geometric model arc olmilar to those obtained fur the original model. Preliminary burnup calculations of the $\mathrm{Li}_{2} \mathrm{O}$ breeder material indicate that one-half the $\sigma_{\mathrm{Li}}$ will be consumed in about $70 \mathrm{~d}$ reactor operation. 


\section{1 .4 Progress and Status}

The tritium production and heating rates for both potential breeder materials $\mathrm{Li}_{2} \mathrm{O}$ and $\mathrm{LiAlO}_{2}$ in the original experiment geometry are given, respectively, in Tables 2.1 .1 and 2.1.2. We used the revised crosssection set to calculate them. Between the materials the basic neutronic response differed only in the smaller breeding rate for $\mathrm{LiAlO}_{2}$. (The tritium breeding rate is calculated in atoms per second per cubic meter, and the lower rate for $\mathrm{LiAlO}_{2}$ simply reflects the lower density of ${ }^{6} \mathrm{Li}$ in this material.). The total heating rate for both materials is very similar. Even though the neutron heating rate is lower for the $\mathrm{LiAlO}_{2}$ because of less ${ }^{6} \mathrm{Li}$, the gamma heating is higher because of the aluminum.

The same type data for $\mathrm{LiAlO}_{2}$ in the modified core geometry is given in Tables 2.1.3 and 2.1.4. The data for $\mathrm{LiAlO}_{2}$ in both original and modified core geometries differ little. However, since the quantity of breeder material in the new geometry is smaller, the inventory of tritium produced will be smaller.

Even though the heating rates have been averaged by zone in all the tables, the variation is only 2 to $3 \%$ from front to back.

To compensate for an overestimate expected in the results obtained from the one-dimensional model used here, the data in Tables 2.1.1 through 2.1 .4 should be reduced by about $25 \%$.

The results of an approximate calculation to determine the burnup of ${ }^{6} \mathrm{Li}$ in the $\mathrm{Li}_{2} \mathrm{O}$ breeder material is presented in Fig. 2.1.1. The lower curve represents the anticipated burnup of the breeder material, using the data obtained directly from a series of one-dimensional calculations.1 The upper curve attempts to account for the overestimate of the burnup rate resulting from the use of the one-dimensional model. The ${ }^{6} \mathrm{Li}$ in the breeder for the core position considered is expected to be one-half burned out in about $70 \mathrm{~d}$ reactor operation time.

\subsubsection{Conclusions and Future Work}

Phase 1 neutronic calculations of the TRIO-01 breeder experiment have been completed. It has been decided recently that the first breeder material will be $\mathrm{LiAlO}_{2}$ and that the concentration of $6_{\mathrm{Li}}$ in the lithium 
Table 2.1.1. Tritium Production Rates in the $\mathrm{Li}_{2} \mathrm{O}$ and $\mathrm{LiAlO}_{2}$ Breeder Materials $a$

\begin{tabular}{lllll}
\hline \multirow{2}{*}{$\begin{array}{c}\text { Radial Position } b, c \\
(\mathrm{~mm})\end{array}$} & \multicolumn{3}{c}{ Tritium Production Rate, atoms $/\left(\mathrm{m}^{3} \cdot \mathrm{s}\right)$} \\
\cline { 2 - 5 } \cline { 5 - 6 } & \multicolumn{2}{c}{${ }^{6} \mathrm{Li}$} & $\mathrm{Li}_{2} \mathrm{O}$ & \multicolumn{2}{c}{$\mathrm{LiAlO}_{2}$} \\
\hline $2.82-5.82$ & $3.89 \times 10^{19}$ & $0.0252 \times 10^{19}$ & $1.93 \times 10^{19}$ & $0.0101 \times 10^{19}$ \\
$5.82-8.81$ & 3.93 & 0.0254 & 1.95 & 0.0102 \\
$8.81-11.8$ & 4.01 & 0.0255 & 1.97 & 0.0103 \\
$11.8-14.8$ & 4.15 & 0.0258 & 1.99 & 0.0104 \\
$14.8-17.8$ & 4.33 & 0.0261 & 2.02 & 0.0105 \\
\hline
\end{tabular}

$a_{\text {Density of }} \mathrm{LiNlO}_{2}$ has been taken to be $70 \%$ of $3.4 \mathrm{Mg} / \mathrm{m}^{3}$. Composition of the lithium is $0.5 \%{ }^{6} \mathrm{Li}$ and $99.5 \%{ }^{7} \mathrm{Li}$.

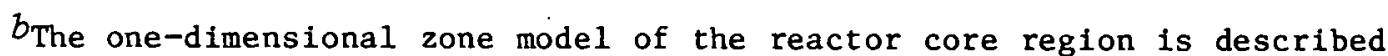
in detail in T. A. Gabriel, R. A. Lillie, and B. L. Bishop, "Neutronic Calculations for the Conceptual Design of an 'In-Pile' Solid Breeder Experiment IPSB-01," ADIP Quart. Prog. Rep. Mar. 31, 1980, DOE/ER-0045/2, pp. 16-18.

cAverage fuel loading of elements around capsule, $140 \mathrm{~g} 235_{\mathrm{U}}$.

Table 2.1.2. Heating. Rates in the $\mathrm{LiO}_{2}$ and $\mathrm{LiAlO}_{2}$ Breeder Materials $a$ and surrounding Strurture $b$

\begin{tabular}{|c|c|c|c|c|c|c|c|}
\hline \multirow{3}{*}{ Zone $^{c}$} & \multirow{3}{*}{$\begin{array}{c}\text { Zonee } \\
\text { Content }\end{array}$} & \multicolumn{6}{|c|}{ Hearing Rare, $M W / \mathrm{m}^{3}$} \\
\hline & & \multicolumn{3}{|c|}{$\mathrm{Li}_{2} \mathrm{O}$} & \multicolumn{3}{|c|}{$\mathrm{LAAlO}_{2}$} \\
\hline & & Neutron & Gamma & Total & Neutron & Gamma & Total \\
\hline 2 & SS & 0.64 & 92.7 & $93: 3$ & 0.67 & 91.3 & 92.0 \\
\hline 3 & Breeder & 24.8 & 13.4 & 38.2 & 12.8 & 23.5 & 36.3 \\
\hline 4 & 88 & 0.66 & 93.4 & 94.1 & 0.68 & 93.5 & 94.2 \\
\hline 3 & Al & 1.12 & 29.3 & 30.4 & 1.18 & 29.7 & 30.9 \\
\hline
\end{tabular}

$a_{\text {Density of }} \mathrm{LiAlO}_{2}$ has been taken to be $70 \%$ of $3.4 \mathrm{Mg} / \mathrm{m}^{3}$.

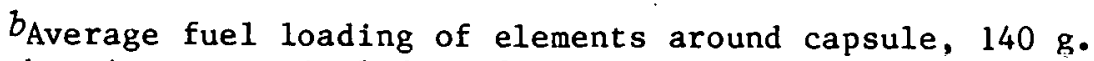
Gamma heating rates include reflected gammas. Composition of the lithium is $0.5 \% 6_{\mathrm{Li}}$ and $99.5 \% 7_{\mathrm{Li}}$.

$c^{c}$ The one-dimensional zone model of the reactor core region is described in detail in T. A. Gabriel, R. A. Lillie, and B. L. Bishop, "Neutronic Calculations for the Conceptual Design of an 'In-P1le' Solid Breeder Experiment IPSB-01," ADIP Quart. Prog. Rep. Mar. 31, 1980, DOE/ER-0045/2, pp. 16-18. 
Table 2.1.3. Tritium Production Rates in the $\mathrm{LiAlO}_{2}$ Breeder Maceriala for Modified Core Geometryc

\begin{tabular}{|c|c|c|}
\hline \multirow{2}{*}{$\underset{(\mathrm{mm})}{\operatorname{Radial} \text { Position }{ }^{c}}$} & \multicolumn{2}{|c|}{$\begin{array}{c}\text { Tritium Production Rate, } \\
\text { at } 2 \mathrm{~ms} /\left(\mathrm{m}^{3} \cdot \mathrm{s}\right)\end{array}$} \\
\hline & ${ }^{6} \mathrm{Li}$ & $7_{\mathrm{Li}}$ \\
\hline $2.82-4.80$ & $2.07 \times 10^{19}$ & $0.0103 \times 10^{19}$ \\
\hline $4.80-6.77$ & 2.09 & 0.0104 \\
\hline $6.77-8.75$ & 2.10 & 0.0104 \\
\hline $8.75-10.7$ & 2.11 & 0.0105 \\
\hline $10.7-12.7$ & 2.13 & 0.0105 \\
\hline
\end{tabular}

$a_{\text {Density of }} \mathrm{LiAlO}_{2}$ has been taken to be $70 \%$ of $3.4 \mathrm{Mg} / \mathrm{m}^{3}$. Composition of the lithium is $0.5 \% 6_{\mathrm{Li}}$ anc $99.5 \% 7_{\mathrm{Li}}$.

$b_{\text {The original one-dimensional zone model }}$ of the reactor core region is described in detail in T. A. Gabriel, R. A. Lillie, and B. L. Bishop, "Neutronic Calculations for the Conceptual Design of an 'In-Pile' Solid Breeder Experiment IPSB-01;" ADIP Quart. Prog. Rep. Mar. 31, 1980, DOE/ER-0045/2, pp. 16-18. The description of the changes are given in the text.

$c_{\text {Average fuel loading of elements around }}$ capsule, $140 \mathrm{~g} 235 \mathrm{U}$.
Table 2.1.4. Heating Rates in the $\mathrm{LiAlO}_{2}$ Breeder Material $a$ and Surrounding Structure $b$ for Modified Core Geometryc

\begin{tabular}{|c|c|c|c|c|}
\hline \multirow{2}{*}{$\begin{array}{c}\text { Zone } \\
-\end{array}$} & \multirow{2}{*}{$\begin{array}{l}\text { Zone } \\
\text { Content }\end{array}$} & \multicolumn{3}{|c|}{$\begin{array}{c}\text { Heating Rates, } \\
\mathrm{MW} / \mathrm{m}^{3}\end{array}$} \\
\hline & & Neutron & Gamma & Total \\
\hline 2 & SS & 0.68 & 92.3 & 93.0 \\
\hline 3 & Breeder & 13.4 & 23.6 & 37.0 \\
\hline 4 & SS & 0.69 & 93.7 & 94.4 \\
\hline 5 & $\mathrm{Al}$. & 1.21 & 29.9 & 31.1 \\
\hline
\end{tabular}

$a_{\text {Density of }} \mathrm{LiAlO}_{2}$ has been taken to be $70 \%$ of $3.4 \mathrm{Mg} / \mathrm{m}^{3}$.

$b_{\text {Average fuel loading of elements }}$ around capsule, $140 \mathrm{~g}$. Gamma heating rates include reflected gammas. Composition of the lithium is $0.5 \%{ }^{6} \mathrm{Li}$ and $99.5 \%{ }^{7} \mathrm{Li}$.

$c_{\text {The original one-dimensional zone }}$ model of the reactor core region is described in detail in T. A. Gabriel, R. A. Lillie, and B. L. Bishop, "Neutronic Calculations for the Conceptual Design of an 'In-Pile' Solid Breeder Experiment IPSB-01," ADIP Quart. Prog. Rep. Mar. 31, 1980, DOE/ER-0045/2, pp. 16-18. The description of the changes are given in the text. 


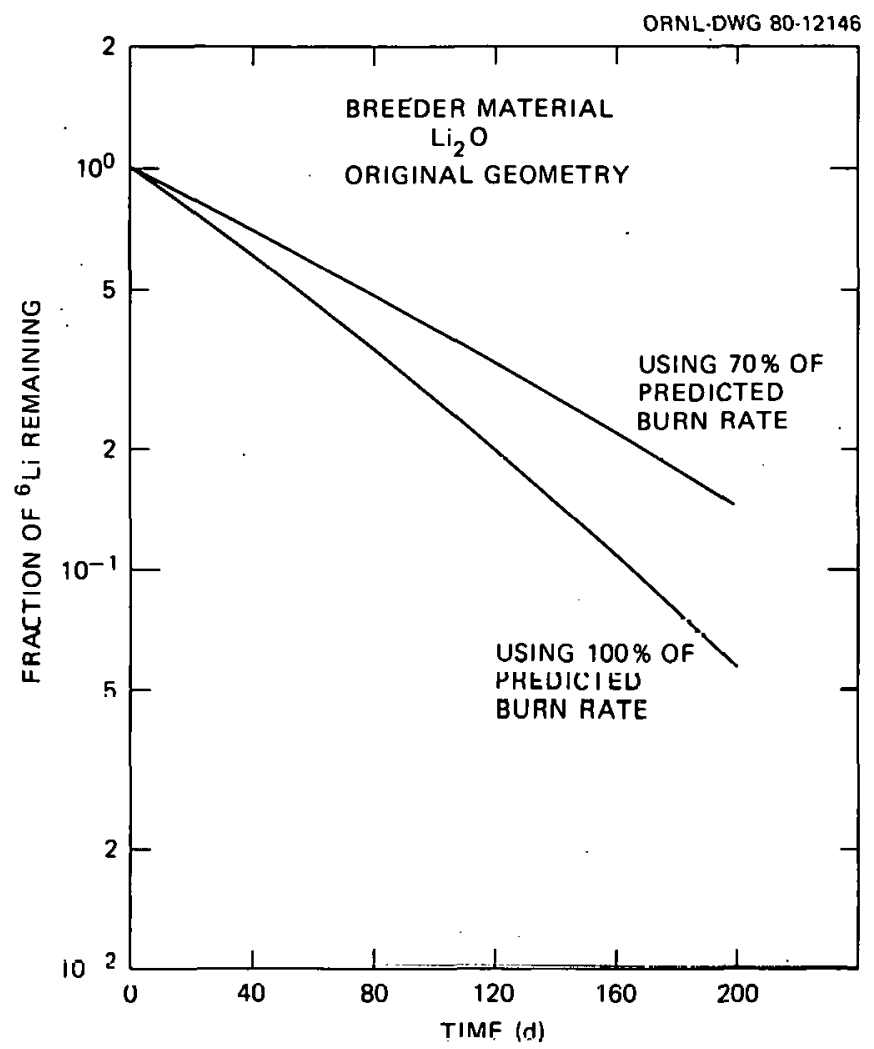

Fig. 2.1.1. Approximate Burnup of the ${ }^{6} \mathrm{Li}$ in the Breeder Material.

will be reduced from its natural levels to $0.5 \%$. Also, the diameter of the experimental capsule will be reduced trom $33.6 \mathrm{~mm}$ to about $25 \mathrm{~mm}$. l'he latter two decisions are based on neutronic considerations. The reduction of the ${ }^{6} \mathrm{Li}$ concentration yields a very uniform energy deposition profile within the breeder, while a reduction in the dimensions of the breeder section diameter will allow a lower temperature gradient $\left(\Delta T<50^{\circ} \mathrm{C}\right)$ across the breeder material.

Now that the core position $A 2$ in the ORR has been tentatively specified for the TRIO-01 breeder experiment, a detailed VENTURE calculation ${ }^{2}$ will be carricd out to obtain a realiotic neutron current source. Definitive one-dimensional calculations can then be obtained. In addition, two-dimensional calculations will be started to remove the overestimation with the one-dimensional analysis. The cross-section set will be updated to include fiseion producte that will act as a neutron poison, and this update will enable us to analyze the TRIO-0l experiment better. 


\subsubsection{References}

1. W. W. Engle, Jr., A User's Manual for ANISN, A One-Dimensional Discrete Ordinates Code with Anisotropic Scattering, K-1693 (1967).

2. D. R. Vondy, T. B. Fowler, and G. W. Cunningham, VENTURE, A Code Block for Solving Multigroup Neutron Problems Applying Fine-DiffusionTheory Approximations to Neutron Transport, ORNL-5062 (October 1975). 
2.2 NEUTRONIC CALCULATIONS IN SUPPORT OF THE ORR-MFE-4A SPECTRAL

TAILORING EXPERIMENT - T. A. Gabrie1, R. A. Lillie, B. L. Bishop, and R. L. Childs (ORNL)

\subsubsection{ADIP Task}

ADIP Task I.A.2, Define Test Matrices and Test Procedures.

\subsubsection{Objective}

The objective of this work is to provide the neutronic design for materials irradiation experiments in the Oak Ridge Research Reactor (ORR). Spectral tailoring to control the fast and thermal neutron fluxes is required to provide the desired displacement and helillm production ratico in alloys containing nickel.

\subsubsection{Summary}

l'hree-dimensional neutronic calculations 1,2 are being carried out to follow the irradiation environment of the ORR-MFE-4A experiment. These calculations currently cover six ORR reactor cycles corresponding to $46,742 \mathrm{MW}$ hrs. This will result in a thermal fluence of $2.03 \times 10^{25}$ neutrons $/ \mathrm{m}^{2}$ and a total fluence of $4.31 \times 10^{25}$ neutrons $/ \mathrm{m}^{2}$. This fluence will produce $1.09 \mathrm{dpa}$ and 3.31 at. ppm He in type 316 stainless steel (not including 2.0 at. ppm He from $10_{\mathrm{B}}$ ). These data and previous calculations have been used to estimate the dates at which the core pieces should be changed and first samples removed.

Through preliminary calculations ${ }^{2}, 3$ we have determined the appropriate sizes of the tungsten core pieres as we1.1. as the heating rateo within them and within the experimental capsules. The reduction in gamma heating resulting from the use of tungsten core pieces may require additional heating of the samples to maintain proper temperature. Calculations similar to those carried nut for the tungsten corc pieces are in progress for hafnium core pieces.

\subsubsection{Progress and Status}

The real-time projections of the helium production and displacement levels based on current calculated data are given in Fig. 2.2.1. The data 




Fig. 2.2.1. Current and Projected Helium-to-Displacement Levels Expected in the ORR-MFE-4A Experiment.

reflect refueling times but not extended shutdown times. By using these data, we conclude that the solid aluminum core piece need not be inserted until the end of August 1981. In addition, the first samples will be removed sometime around March 31, 1982, at approximately $10 \mathrm{dpa}$. After the first nickel test wire has been removed from the center of the experimental capsule and analyzed for helium content (sometime around the end of October 1980), the data in Fig. 2.1.1 can be revised, if necessary. The helium data will allow modification of the helium production equation, which was obtained from High Flux Isotope Reactor (HFIR) data. This equation is currently being used for nickel-bearing alloys to calculate the helium production level in the ORR thermal neutron fluence.

The heating rates calculated within both the tungsten core pieces and the experimental capsules are given in Table 2.2.1, and the geometric model used for calculations is shown in Fig. 2.2.2. The approximate sizes of the tungsten core pieces are given in Table 2.2.2, and the relative change of the thermal neutron flux resulting from the use of these core pieces is given in Fig. 2.2.3. 
Table 2.2:-. Energy Deposition Rates in the ORR-MFE-4A TEst Capsule and in the Tungsten and Water Surrounding the Capsile

\begin{tabular}{|c|c|c|c|c|c|c|c|c|}
\hline \multirow{2}{*}{$\begin{array}{l}\text { Spatial } \\
\text { Intervala } \\
(\mathrm{mm})\end{array}$} & \multirow{2}{*}{ Maier:a- } & \multicolumn{5}{|c|}{ Energy Ireposition Rate, $b \mathrm{kH} / \mathrm{kg}$, for Volume } & \multicolumn{2}{|c|}{ Fractions of Tungsten $x$} \\
\hline & & $\mathrm{C} \%$ & & $10 \%$ & & $20 \%$ & $50 \%$ & $67 \%$ \\
\hline $0-22.2$ & $S S-$ (lTaE) & $11.3^{c}(10.5)$ & 6.6 & $(6.6)$ & 4.9 & $(5.0)$ & $2.6(2.8)$ & $2.1(2.2)$ \\
\hline $22.2-24.2$ & Al & 11.4 & 6.7 & & 4.9 & & 2.6 & 2.1 \\
\hline $24.2-25.8$ & $\mathrm{~W}+\left(\mathrm{H}_{2}\right): \ddot{c}$ & & $10 \cdot 6$ & $6(12.0)$ & 7.5 & $(9.9)$ & $3.8(7.0)$ & $2.9(6.2)$ \\
\hline $25.8-27 . \hat{i}$ & & & 13.5 & $5(12.6)$ & 7.4 & & 3.6 & 2.7 \\
\hline $27.2-28 . \varepsilon$ & & & & & 8.2 & & 3.8 & 2.8 \\
\hline $28.8-30.2$ & & & & & 12.0 & $0(11.4)$ & 4.0 & 3.0 \\
\hline $30.2-32.1$ & & & & & & & $\dot{4} .4$ & 3.2 \\
\hline $32 \cdot 1-34.0$ & & & & & & & 5.1 & 3.5 \\
\hline $34.0-35.7$ & & & & & & & 6.0 & 4.0 \\
\hline $35.7-37.4$ & & & & . & & & $9.3(8.8)$ & 4.6 \\
\hline $37.4-39.2$ & & & & & & & & 5.5 \\
\hline $39.2-41.0$ & & & & & & & & $8.5(9.5)$ \\
\hline
\end{tabular}

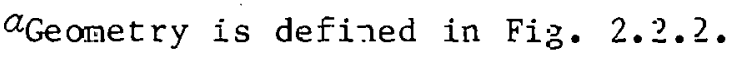

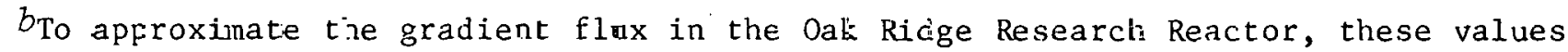
have been reduced by $25 \%$ from the results obtained from the one-dinensional AivISN calculations [W. W. Engle, Jr., A User's Manual for ANIiN, A One-Dimensionai Discrete Ordinates Code with Arisotrofic Scattering, K- -693 (1967)]. Numbers in parentheses are values for the materials in parentheses.

cAs discussed $-n$ zext, measired results indicate this heating rate to be 7 to $8 \mathrm{~kW} / \mathrm{kg}$. The calculated values 'Nill be renormalized.

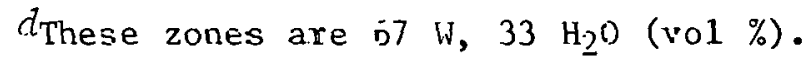




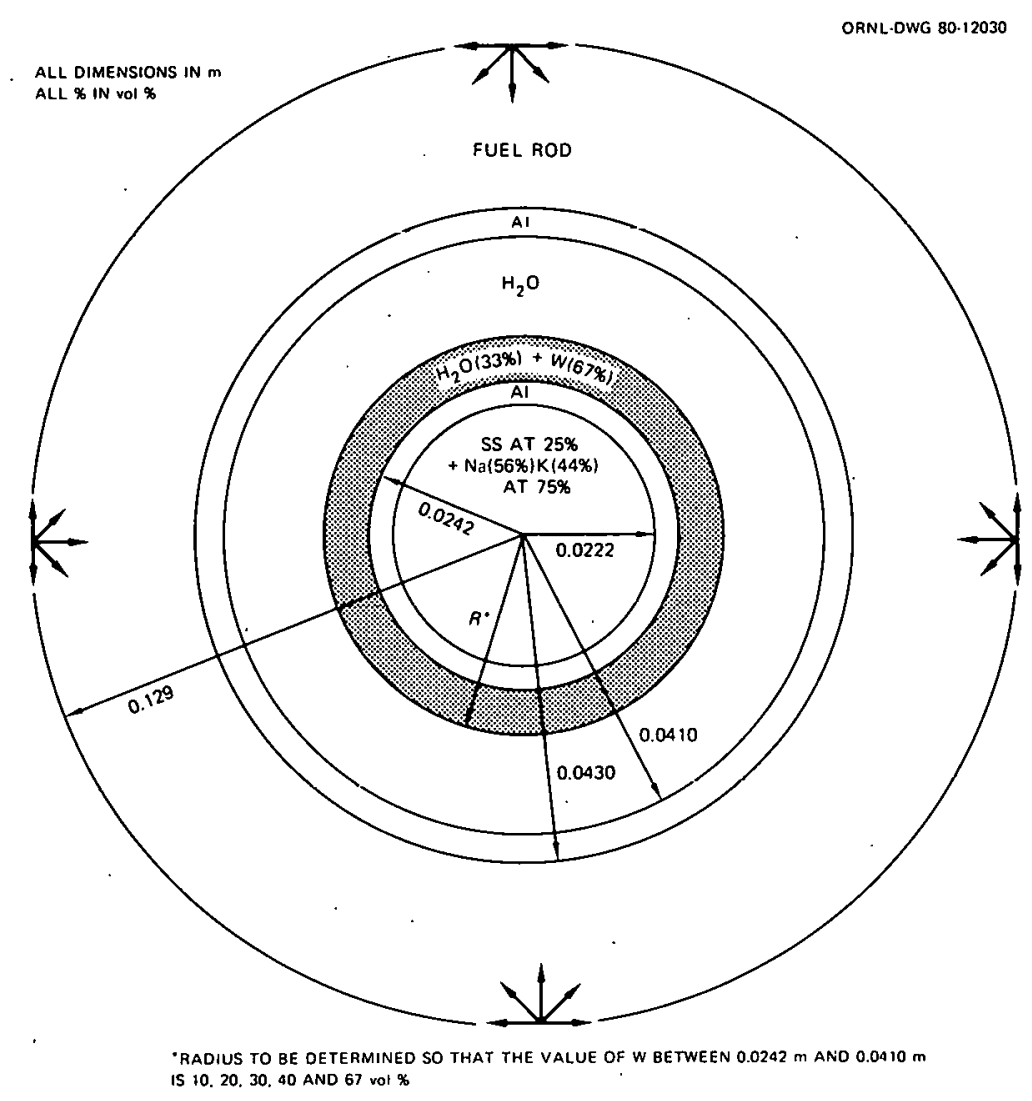

Fig. 2.2.2. One-Dimensional Model of the ORR-MFE-4A Experiment and Surrounding Oak Ridge Reactor Core Region. The tungsten core pieces are shaded. The outer circle is a distributed neutron source representing the reactor core beyond the experiment region.

Table 2.2.2. Approximate Sizes of the Tungsten Cylinders for the ORR-MFE-4A Experiment $a$

\begin{tabular}{|c|c|c|c|c|}
\hline \multirow{2}{*}{ Cylinder } & \multirow{2}{*}{$\begin{array}{l}\text { Tungsten } \\
\text { Surrounding } \\
\text { MFE-4A } \\
(\text { vol \%) }\end{array}$} & \multicolumn{2}{|c|}{$\underset{\mathrm{mm}}{\text { Cylinder Radii, }}$} & \multirow{2}{*}{$\begin{array}{c}\text { Cylinder Thickness, } \\
\Delta R \\
(\mathrm{~mm})\end{array}$} \\
\hline & & Inner & Outer & \\
\hline 1 & 5 & 26.2 & 27.4 & 1.2 \\
\hline 2 & 10 & 29.4 & 31.5 & 2.1 \\
\hline 3 & 10 & 33.5 & 35.4 & 1.9 \\
\hline 4 & 15 & 33.5 & 36.2 & 2.7 \\
\hline 5 & 25 & 33.5 & 37.9 & 4.4 \\
\hline
\end{tabular}

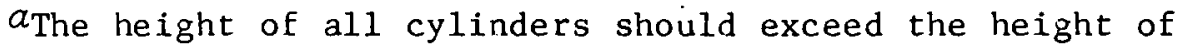
the active core, which $1 \mathrm{~s}$ about $0.6 \mathrm{~m}(24 \mathrm{in.})$ or more. 


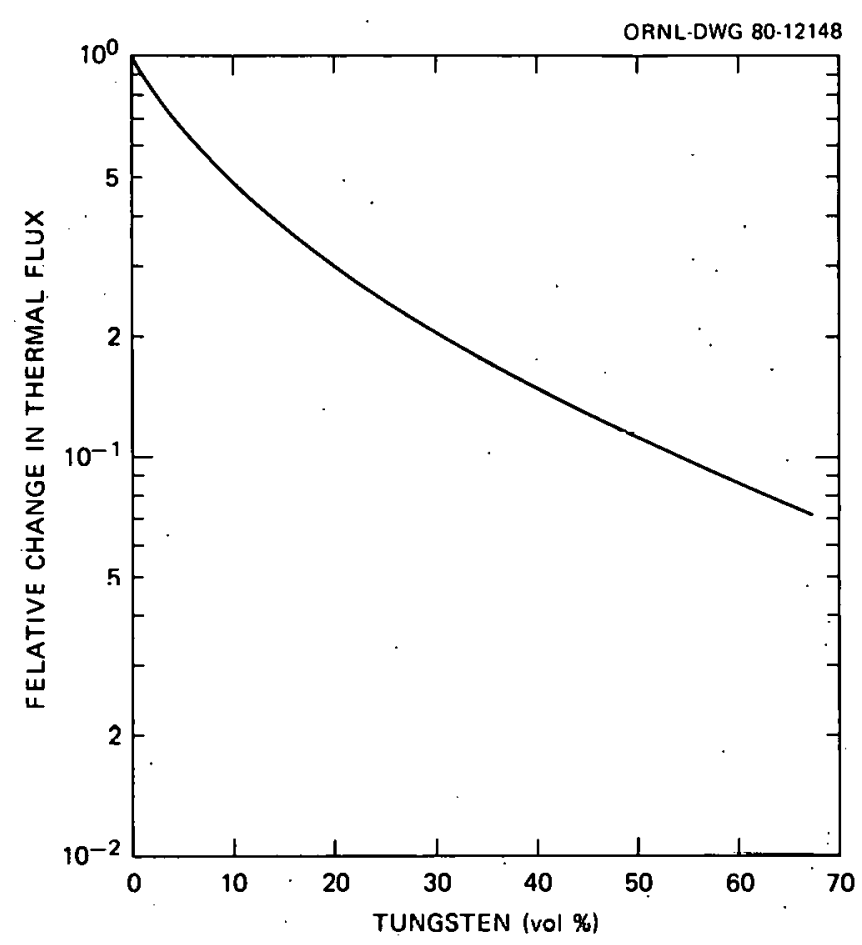

Fig. 2.2.3. Variation of the Thermal Flux as a Function of the Volume Percent of Tungsten Surrounding the ORR-MFE-4A Experiment.

Experimental heating rates obtained for stainless steel indicate our. calculated results lin Tuble 2.2 .1 to be about $35 \%$ too high. Since a nnedimensional model ${ }^{2}$ (Fig. 2.2.2) has been used for these calculations, this discrepancy is not unreasonable. For design purposes the data in Table 2.2 .1 will be renormalized to 7 to $8 \mathrm{~kW} / \mathrm{kg}$ Lelalive to stainlcoo steel. As can be seen from the data in Table 2.2.1, a rather large decrease in the heating rate in stainless steel (and in the NaK) results from the use of tungsten core pieces. Because of this reduction, additional heating of the samples to maintain proper temperature may be necessary.

By using various combinations of the cylindrical concentric tungsten core pieces (see shaded area of Fig. 2.2.2) described in Table 2.2.2, the percentage of tungsten surrounding the MFE-4A experiment can be varied from 5 to $40 \%$, mostly in increments of $5 \%$. By using cylinders 1, 2, and 5 , which would comprise $40 \%$ of the exterior volume, the thermal flux can be reduced by about $85 \%$ (see Fig. 2.2.2). Previous considerations and calculations show that this reduction in the thermal flux is the maximum that may be required. 
A 2-mm coolant water gap has been allowed between each cylinder. This gap may or may not be sufficient for proper cooling. When various tungsten pieces are not in place, aluminum cylinders of similar sizes will be used to prevent water from thermalizing the fast neutrons.

\subsubsection{Future Work}

The one-dimensional cylindrical model (Fig. 2.2.2) used to calculate heating rates and flux reductions for the tungsten core pieces will be used to generate similar data for hafnium core pieces, once hafnium transport cross sections have been obtained. Hafnium has several advantages over tungsten. Since hafnium has a thermal neutron capture cross section about 5 times larger than tungsten, the thickness of the hafnium core pieces can be made about $70 \%$ thinner. Since gamma attenuation is similar in the two materials, this results in less reduction in gamma heating within the stainless steel. In addition, fabrication of the hafnium core pieces may be easier and less costly than for tungsten. However, the major drawback is that the hafnium burnup may possibly require periodic replacement of these core pieces.

The three-dimensional neutronics calculations that monitor the radiation environment of the ORR-MFE-4A experiment will continue with each reactor cycle.

\subsubsection{References}

1. D. R. Vondy, T. B. Fowler, and G. W. Cunningham, VENTURE, A Code Block for Solving Multigroup Neutron Problems Applying Fine-DiffusionTheory Approximations to Neutron Transport, ORNL-5062 (October.1975).

2. T. A. Gabriel, R. A. Lillie, B. L. Bishop, and R. L. Childs, "Neutronic Calculations in Support of the ORR-MFE-4 Spectral Tailoring Experiment," ADIP Quart. Prog. Rep: June 30, 1980, DOE/ER-0045/3, pp. 7-9.

3. W. W. Engle, Jr., A User's Manual for ANISN, A One-Dimensional Discrete Ordinates Code with Anisotropic Scattering, K-1693 (1967). 
2.3 OPERATION OF THE ORR SPECTRAL TAILORING EXPERIMEINT ORR-MFE-4A K. R. Thorns and M. L. Grossbeck (ORIL)

\subsubsection{ADIP Task}

ADIP Task I.A.2, Define Test Matrices and Test Procedures.

\subsubsection{Objective}

Through neutron spectrum tailoring, this experiment will irradiate austenitic stainless steels to achieve the same helium-to-displacementper-atom (He/dpa) ratio as predicted for fusion reactor first-wall service. 'lhe experiment is irradiating type 316 stainless steel and Path A Prine Candidate Alloy (PCA) at temperatures near 300 and $400^{\circ} \mathrm{C}$.

\subsubsection{Summary}

This experiment consists of two test regions designed to irradiate type 316 stainless steel and Path A PCA at constant temperatures of 300 and $400^{\circ} \mathrm{C}$. The ORR-MFE-4A experiment was installed in the Oak Ridge Research Rcactor (ORR) on June 10, 1980, and as of September 30 has operated successfully for an equivalent $99 \mathrm{~d}$ at $30 \mathrm{NW}$ reactor power with maxinum specimen temperatures in each region of 330 and $400^{\circ} \mathrm{C}$ respectively.

\subsection{4 progress and Status}

The detajls of the ORR spectral talloring cxperinents have been described previously.1,2 The ORR-MFE-4A irradiation capsule was installed in the ORR on June 10, 1980, and as of September 30 has operated successfully for an equivalent $99 \mathrm{~d}$ at $30 \mathrm{NW}$ reactor power with the maximum specimen temperatures in the upper and lower test regions being controlled at 400 and $330^{\circ} \mathrm{C}$ respectively.

A schematic of the MFL-4 capsule destgn is shown in Fig. 2.3.1. Ihis ligure shows the location of the six thermocouples and two control gas annuli that are used to monitor and control the temperature of the test specimens in each region. Thermocouples 1,2 , and 3 and control gas annulus $\Lambda$ monitor and control the $400^{\circ} \mathrm{C}$ region, while thermocouples 4, 5, and 6 and control gas annulus $B$ perform the same function for the $300^{\circ} \mathrm{C}$ region. 


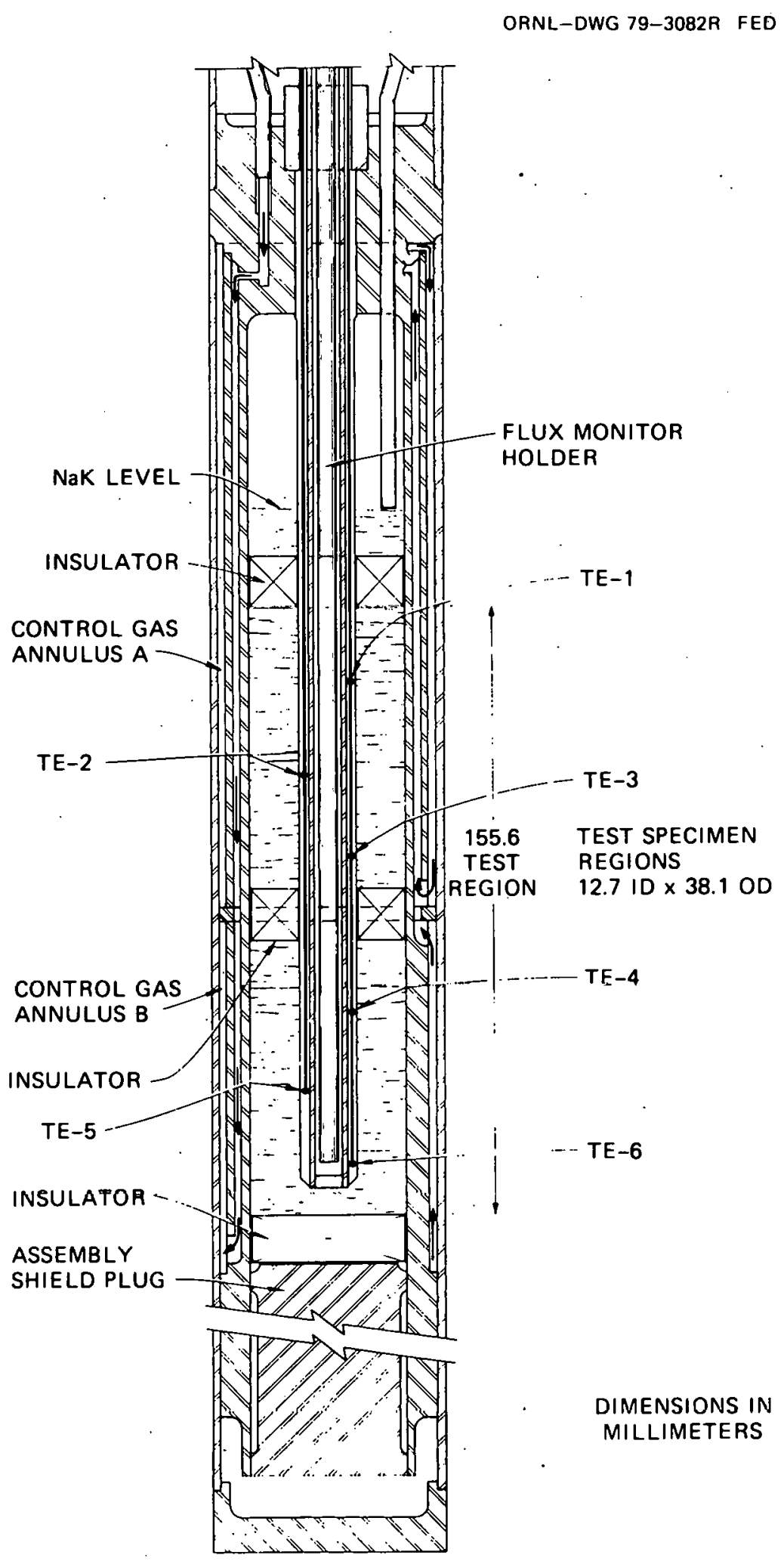

Fig. 2.3.1. Schematic of ORR-MFE-4A Irradiation Capsule Design. Thermocouple locations are indicated by $\mathrm{TE}$. 
During the design of the capsule, a one-dimensional heat transfer analysis using the GENGTC heat transfer $\operatorname{code}^{3}$ was performed to size the control gas gaps to allow enough flexibility to control the capsule temperature (with helium-neon gas mixtures) during the expected changes in gamma heating rates through the typical two- to three-week reactor fuel cycles. We chose $0.127-\mathrm{mm}\left(0.005-\mathrm{in}\right.$.) cold gas gaps for the $400^{\circ} \mathrm{C}$ region and $0.076-\mathrm{mm}\left(0.003-i n_{.}\right)$ones for the $300^{\circ} \mathrm{C}$ region.

The experiment was installed in the reactor on June 10,1980, and the reactor was started up on June 12 with $100 \%$ He in both control gas annuli. Figure 2.3.2 compares measured and calculated temperatures with $100 \%$ He, indicating fairly good agreement between them. This was reassuring and confirmed that our attempt to measure the gamma heat in the facility in

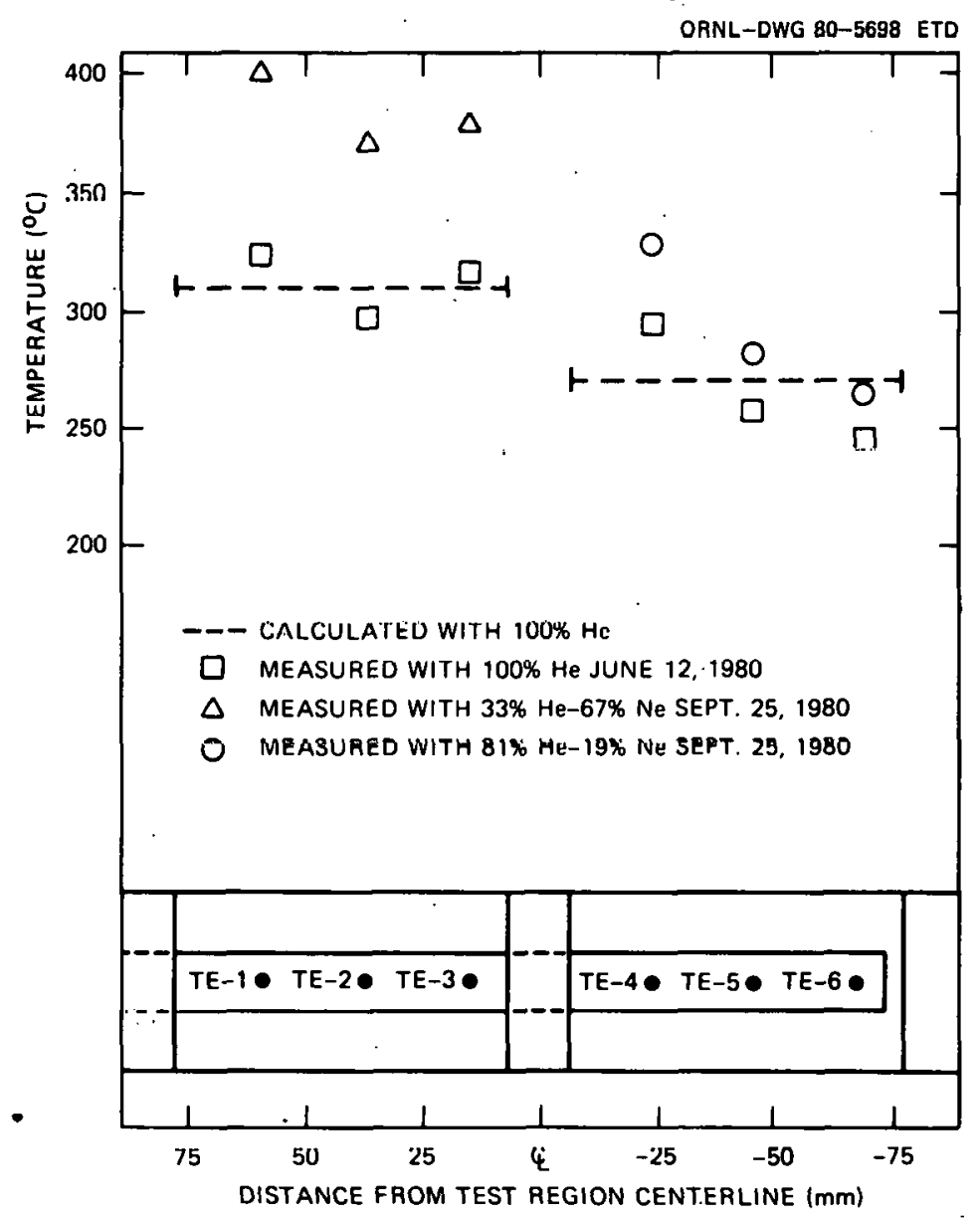

Fig. 2.3.2. Calculated and Measured lemperature Data in Irradiation Capsule ORR-MFE-4A. 
July 1979 was successful. The upper region of the capsule. (TE-1) was brought to a maximum of $400^{\circ} \mathrm{C}$, but since the highest reading thermocouple in the lower region was already very close to $300^{\circ} \mathrm{C}$, we decided to keep $100 \%$ He in the lower control gas region to observe how the temperatures would change during the reactor fuel cycle. After about one week of operation, the maximum temperature of the lower region (TE-4) had increased to $312^{\circ} \mathrm{C}$. Since it was necessary that we operate at a temperature with a gas mixture that would allow for control through an entire fuel cycle as well as for slightly varying fuel loadings, we decided to operate the lower cell at a maximum of $330^{\circ} \mathrm{C}$. We have been able to maintain control of the capsule, that is, TE-1 at $400^{\circ} \mathrm{C}$ and $\mathrm{TE}-4$ at $330^{\circ} \mathrm{C}$, with $\pm 5^{\circ} \mathrm{C}$ variation through the irradiation period to date.

Because of the relatively large gamma heating rate $(\sim 7 \mathrm{~kW} / \mathrm{kg})$ and large test region annulus ( $12.7 \mathrm{~mm}$ thick), there is a severe radial. temperature difference of about $80^{\circ} \mathrm{C}$ from the inner to the outer surfaces of the test region. At present, a two-dimensional heat transfer analysis is under way, using the HEATING5 computer program ${ }^{4}$ so that a complete axial and radial temperature profile can be obtained for each test region. During the loading of the MFE-4A experiment, care was taken to record the actual physical location of each test specimen. This information, along with the heat transfer analysis, should allow us to report fairly accurate irradiation temperatures for each specimen. The 2-D heat transfer analysis should also help us determine the cause of, and hopefully a means to correct, the fairly large axial temperature gradient in the lower test region.

Another effort presently under way for capsule MFE-4A is developing the technique to remove flux monitor wires from the center of the experiment. In Fig. 2.3.1, the flux monitor holder is shown. Inside this holder is a $3.2-\mathrm{mm}-0 \mathrm{D}(0.125-\mathrm{in.})$ stainless steel flux monitor tube, which contains nineteen $0.25-\mathrm{mm}-O D\left(0.010-i n_{\text {. }}\right)$ nickel wires and a 1-mm-OD (0.040-in.) stainless steel tube containing a 0.5 -mm (0.020-in.) vanadiumcobalt wire, a 0.25-mm (0.010-in.) titanium wire, and a 0.25-mm (0.010-in.) iron wire. Plans call for removing one nickel wire and the 1-mm stainless steel tube after about every $120 \mathrm{~d}$ of irradiation. This is to be done by 
removing the $3.2-\mathrm{mm}$ tube, which is about $7.6 \mathrm{~m}(25 \mathrm{ft}$ ) 1ong; taking it to the ORR hot cell; and removing the wires. A new $1-\mathrm{mm}$ tube with fresh vanadium-cobalt, titanium, and iron wires will be loaded into the flux monitor tube, which then will be reloaded into the capsule for another 120-d irradiation. We should point out that though these are not the reference flux monitors, they will be used to confirm the neutronics calculations being performed by T. A. Gabriel and co-workers to determine when core pieces need to be changed to change the flux spectrurn. The reference monitors were supplied by the Fusion Reactor Materials Dosimetry activity at Argonne National Laboratory and were loaded in the capsule with the rest specimens. These monitors will be removed after $10 \mathrm{dpa}$ along with several of the test specimens.

Present plans call for rewovilug the flux monitor tuhe during the next major shutdown of the ORR, scheduled for the week of November 10 through 14, 1980.

\subsubsection{Conclusions}

The first. ORR spectral tailoring capsule, ORR-MFE-4A, has operated successfully for an equivalent $99 \mathrm{~d}$ at $30 \mathrm{MW}$ reactor power with maximum specimen temperatures in the two test regione being controlled at 330 and $400^{n} \mathrm{C}$, respectively. A two-dimensional heat transfer analysis is under way lu glve a complete thermal picture of the test rcgions. The first attempt at removal of flux monitors to confirm neutronics calculations is being planned with the actual removal to take place during the second week of November 1980.

\subsubsection{References}

1. T. A. Gabriel, K. R. Thoms, and M. T., Frossbeck, "Dcoign of Materials Irradiation Experiments in the ORR Utilizing Spectral Tailoring and - Keencapsulatiui," ADIP Quart. Prog. Rep. Mar. 31, 1979, DOE/ET-0058/5, pp. 20-22.

2. T. A. Gabriel, K. R. Thoms, and J. W. Woods, "Design of Materials Irradiation Experiments Utilizing Speclcal Ta1loring," aDlP Quart. Prog. Rep. Dec. 31, 1978, DOE/ET-0058/4, Pp. 10-17. 
3. H. C. Roland, GENGTC: A One-Dimensional Computer Program for Capsule Temperature calculation in Cylindrical Geometry, ORNL/TM-1942 (December 1967).

4. W. D. Turner, D. C. Elrod, and I. I. Siman-Tov, HEATING5 - An IBM 360 Heat Conduction Program, ORNL/CSD/TM-15 (March 1977). 
2.4 HFIR-MFE-T1, -T2, AND -RB1: EXPERILENTS TO EVALUATE THE EFEECTS OF LOW-TEMPERATURE IRRADIATION ON FERRITLC STEELS - J. M. Vitek, R. L. Klueh, M. L. Grossbeck, and J. W. Woods (ORNL)

\subsubsection{ADIP Task}

ADIP Task I.A.2, Define Test Matrices and Test Procedures. .

\subsubsection{Objective}

The objective of these experiments is to acquire data on the effects of low-temperature irradiation on the properties of ferritic steels. The High Flux Isotope Reactor. (HFIR) irradiation will result in concurrent helium and displacement production. A broad range of sample lypes is lu be irradiated, including some larger specinens that cannot be accommodated in other HFLR target region irradiation experiments.

\subsubsection{Summary}

Three experinents for the irradiation of ferritic steels in the HFIR have been outlined. All three experiments are to operate at about $50^{\circ} \mathrm{C}$. They will provide the first substantial data on the effects of helium and displacement production on several properties, including fatigue, tensile, Charpy impact, crack growth, and fracture toughness. The steels to be tested include $12 \mathrm{Cr}-1$ Mo (HT9), nickel-doped $12 \mathrm{Cr}-1 \mathrm{Mo}$, $9 \mathrm{Cr}-1 \mathrm{Mo}$, nickel-doped $9 \mathrm{Cr}-1 \mathrm{Mo}, 21 / 4 \mathrm{Cr}-1 \mathrm{Mo}$, and welds of some of these. Test results will complement elevated-temperature Experimental Breeder Reactor (EBR-II) irradiation experiments on the same alloys. Test matrices and fluence levels have been defined, and the experiments are expected to be ready for insertion in late 1980 or early 1981.

\subsubsection{Progress and Status}

\subsubsection{Introduction}

The experiments $\mathrm{HFIR-MFE}-\mathrm{T} 1$ and $-\mathrm{T} 2$ ( $\mathrm{T}$ for target position in HFIR) and $H F I R-M F E-R B I$ ( $R B$ for beryllium reflector position) are planned to 
provide the first data for several properties of ferritic steels irradiated in a neutron environment producing both displacements and transmutation helium. Specimens from the T1 and T2 experiments will be the first to generate fatigue information under these conditions and will provide a basis for future elevated-temperature irradiation studies.

The RBI experiment is much broader in scope. In addition to specimens to supplement the fatigue results from experiments $\mathrm{T} 1$ and $\mathrm{T} 2$, many other types of samples will be irradiated. With the larger irradiation volume available in the reflector position, it will be possible to irradiate samples that do not fit in any other HFIR location. Moreover, the large volume will allow for an extensive set of tests on several different alloys. Many of the same alloys and samples are being irradiated in the EBR-II, $A D-2$ experiment. This will allow comparison of results at different irradiation temperatures and at different helium levels. Irradiation of the $\mathrm{T} 1$ and $\mathrm{T} 2$ capsules is expected to begin in late 1980, while irradiation of the RB1 capsule should begin in early 1981. Completion of the lower fluence irradiations is expected in mid to 1ate 1981.

\subsubsection{Experimental Design}

These experiments will be conducted at the reactor conlant temperature, $50^{\circ} \mathrm{C}$. To avoid excessive corrosion of the ferritic steels in the reactor coolant, the samples will be enclosed in thin-wall aluminum tubing. Size limitations to avoid excessive specimen heating have been calculated. Assuming conduction of heat within the ferritic steel to be the controlling factor, a cross-section thickness of less than $5 \mathrm{~mm}$ ( 0.2 in.) will ensure a temperature difference of less than $25^{\circ} \mathrm{C}$ within the sample.

Procedures have been developed for the encapsulation of samples in thin-wall aluminum tubing. Sheet samples will be stacked in sets of five or six hefore insertion. In the RBI experiment only similar samples will be put in any given tube, whereas rod tensile and rod fatigue samples will be combined in the same tube in each of the T1 and T2 experiments. These samples or stacks of samples stacks are inserted into tubes sealed at one end. The sample tubes are then evacuated and an external pressure 
of approxinately $9 \mathrm{MPa}(1300 \mathrm{psi})$ is applied. Collapse of the aluminum tubing is imnediate. The collapsed tubing follows the sample contours quite we11, as shown in Fig. 2.4.1.

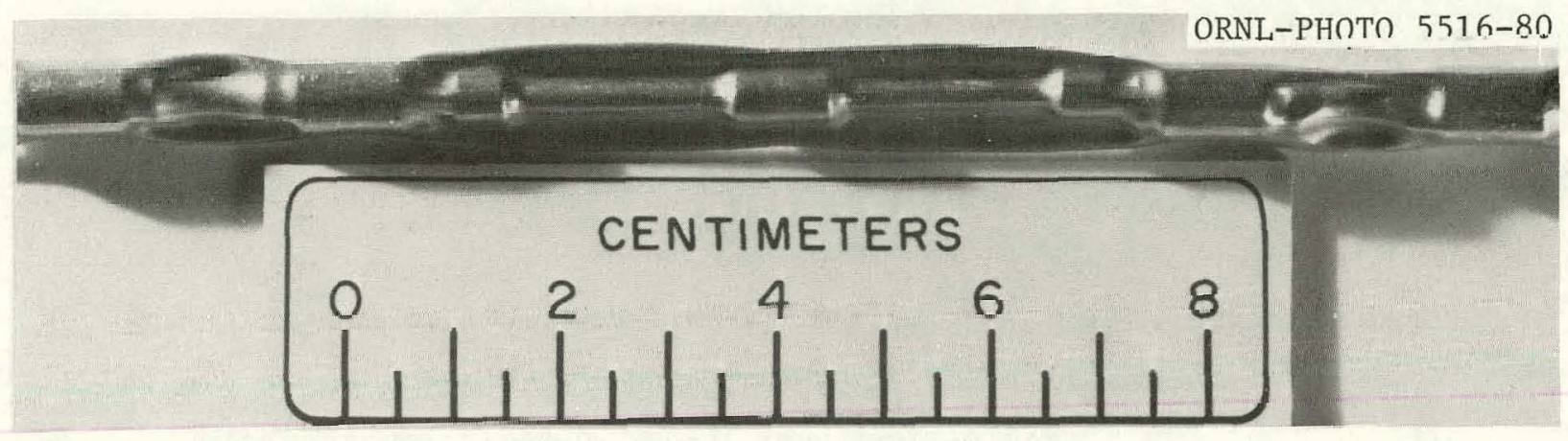

Fig. 2.4.1. T'ensile and Fatigue Samples Eucapsulated in I'hin-Wall Aluminum Tubing.

Eight different sample geometries will be included in the $\mathrm{T} 1$, $\mathrm{T} 2$, and RB1 experiments. Brief descriptions of these samples are given in Table 2.4.1. The sample geometries are essetially identical to those used in previous irradiation experiments. The only alteration will be on the rod tensile samples, illustrated in an earlier report. ${ }^{1}$ The spurs al the ends of the samples will be eliminated. Detailed drawings of the other specimens [except the transmission electron microscopy (TEM) disks] were in the last ADIP quarterly. ${ }^{2}$

\subsubsection{HFIR-MFE-T1 and -T2 Test Matrix and Irradiation Conditions}

The materials to be irradiated in these experiments will include the following alloy steels: $12 \mathrm{Cr}-1$ Mo (HT9 type), $12 \mathrm{Cr}-1 \mathrm{Mo}-1 \mathrm{Ni}$, $12 \mathrm{Cr}-1 \mathrm{Mo}-2 \mathrm{Ni}, 9 \mathrm{Cr}-1 \mathrm{Mo}, 9 \mathrm{Cr}-1 \mathrm{Mo}-2 \mathrm{Ni}$, and $21 / 4 \mathrm{Cr}-1 \mathrm{Mo}$. The 12 and $9 \mathrm{Cr}$ alloys are from Combustion Engineering ( $\mathrm{CE}$ ) heats and have been described previuusly. ${ }^{3}$ The $21 / 4 \mathrm{Cr}-1$ lo alloy is from the breeder program heat 38649. All alloys will be irradiated in the normalized and tempered conditions. The specific heat treatments are the same as those given to ferritic allnys in HFIR-CTR-30 through -33 and are summarized in Table 2.4.2.

The two capsules will be identical except for goal fluence levels, given in Table 2.4.3. These two experiments each contain 13 specimens 
Table 2.4.1. Description of Specimen Geometries to Be Used

\begin{tabular}{|c|c|c|c|c|c|c|c|}
\hline \multirow{2}{*}{ Specimen $a$} & \multirow{2}{*}{ Form } & \multicolumn{4}{|c|}{ Dimensions, mm } & \multicolumn{2}{|c|}{ Reference Drawing } \\
\hline & & Thickness & Length & Width & Diam & Source $b$ & No. \\
\hline Rod tensile - RT & Rod & & 30.2 & & 4.06 & ORNL & SK 270 \\
\hline Sheet tensile - ST & Sheet & 0.762 & 44.4 & 4.95 & & HEDL & $\mathrm{H}-3-37395$ \\
\hline $\begin{array}{l}\text { Fatigue initiation - FI } \\
\text { (hourglass fatigue) }\end{array}$ & Rod & & 45.2 & & 6.35 & ORNL & $M-11950-E M-003 C$ \\
\hline Grodzinski fatigue - GF & Sheet & 0.762 & 44.4 & 4.95 & & $\begin{array}{l}\text { McDonnell } \\
\text { Douglas }\end{array}$ & O0E057069A \\
\hline Miniature Charpy $-C$ & $\begin{array}{l}\text { Square } \\
\text { rod }\end{array}$ & & 23.6 & 5.0 & & HEDL & $\mathrm{H}-3-46299$ \\
\hline $\begin{array}{l}\text { Fracture toughness }-\mathrm{CT} \\
\text { (compact tension) }\end{array}$ & Disk & 2.54 & & & 16 & HEDL & $\mathrm{H}-3-46752$ \\
\hline $\begin{array}{l}\text { Crack growth - CG } \\
\text { (miniature CCT) }\end{array}$ & Sheet & 0.762 & 12.7 & 25.4 & & HEDL & $\mathrm{H}-3-46018(\mathrm{Pt} \quad \mathrm{A})$ \\
\hline $\begin{array}{l}\text { Transmission electron } \\
\text { microscopy - TEM }\end{array}$ & Disk & 0.25 & & & 3.0 & & \\
\hline
\end{tabular}

$a_{\mathrm{Alternative} \mathrm{names}}$ ir. parentheses; abbreviations are listed at end of names.

$b_{\text {OENL }}=$ Oak Ridge National Laboratory; HEDL = Hanford Engineering Development Laboratory. 
Table 2.4.2. Specimen Heat Treatments for Samples in HFIR-MFE-T1 and -T2

\begin{tabular}{|c|c|c|c|c|}
\hline \multirow[b]{2}{*}{ Alloy } & \multirow[b]{2}{*}{ Heat $a$} & \multirow{2}{*}{$\begin{array}{c}\text { Normalized } \\
\text { Temperature } \\
\left({ }^{\circ} \mathrm{C}\right)\end{array}$} & \multicolumn{2}{|c|}{ Tempered } \\
\hline & & & $\begin{array}{l}\text { Temperature } \\
\left({ }^{\circ} \mathrm{C}\right)\end{array}$ & $\begin{array}{l}\text { Time } \\
\text { (h) }\end{array}$ \\
\hline $12 \mathrm{Cr}-1$ Mo & CE 3587 & 1050 & 780 & 2.5 \\
\hline $12 \mathrm{Cr}-1 \mathrm{Mo}-1 \mathrm{Ni}$ & CE 3588 & 1050 & 780 & 2.5 \\
\hline $12 \mathrm{Cr}-1 \mathrm{Mo}-2 \mathrm{Ni}$ & CE 3589 & 1050 & 700 & 5 \\
\hline $9 \mathrm{Cr}-1 \mathrm{Mo}$ & CE 3590 & 1040 & 760 & 1 \\
\hline $9 \mathrm{Cl}_{i}-1 \mathrm{Hu}-2 \mathrm{Ni}$ & CE 3591 & 1040 & 700 & 5 \\
\hline $21 / 4 \quad \mathrm{Cr}=1$ WU & B 38649 & 900 & $700 \cdots$ & 1 \\
\hline
\end{tabular}

Table 2.4.3. Projected HFIR Irradiation Conditions at the Midplane of the Three Experiments

\begin{tabular}{|c|c|c|}
\hline Experiment & $\begin{array}{l}\text { Displacement Leve } 1 a \\
\text { (dpa) }\end{array}$ & Cycles $b$ \\
\hline HFIR-MFE-TI & 70 & 32 \\
\hline HFIR-MFE-T2 & 10 & 5 \\
\hline HFIR-MFE-RB $\perp^{c}$ & $\begin{array}{l}10 \\
20\end{array}$ & $\begin{array}{l}14 \\
28\end{array}$ \\
\hline \multicolumn{3}{|c|}{$\begin{array}{l}\text { aValues at capsule midplane. The speri } \\
\text { men at the end of the capsule will achieve } \\
\text { approximately one-half the midplane value. } \\
h_{A} \text { HFTR cycle is approximatcly } 23 \mathrm{~d} \text {. } \\
c_{\text {Two fluence levels are planned for this }} \\
\text { capsule. }\end{array}$} \\
\hline
\end{tabular}


of cylindrical geometry, consisting of hourglass fatigue and rod tensile samples. The experiments will be irradiated in the outermost HFIR target positions, adjacent to peripheral target positions. Flux monitors will be included in two locations in each capsule: near one end and near the center. The tentative specimen loading matrix is presented in Table 2.4.4.

Table 2.4.4. Specimen Loading Matrix for HFIR-MFE-T1 and $-\mathrm{T} 2$

\begin{tabular}{|c|c|c|}
\hline Position & Alloy & Sample Type \\
\hline 1 & $12 \mathrm{Cr}-1 \mathrm{Mo}$ & Fatigue initiation \\
\hline 2 & $12 \mathrm{Cr}-1 \mathrm{Mo}$ & Rod tensile \\
\hline 3 & $12 \mathrm{Cr}-1 \mathrm{Mo}-1 \mathrm{Ni}$ & Rod tensile \\
\hline 4 & $9 \mathrm{Cr}-1 \mathrm{Mo}$ & Rod tensile \\
\hline 5 & $12 \mathrm{Cr}-1 \mathrm{Mo}$ & Rod tensile \\
\hline 6 & $12 \mathrm{Cr}-1 \mathrm{Mo}-1 \mathrm{Ni}$ & Rod tensile \\
\hline 7 & $12 \mathrm{Cr}-1 \mathrm{Mo}-1 \mathrm{Ni}$. & Fatigue initiation \\
\hline 8 & $12 \mathrm{Cr}-1 \mathrm{Mo}-2 \mathrm{Ni}$ & Fatigue initiation \\
\hline 9 & $12 \mathrm{Cr}-1 \mathrm{Mo}-2 \mathrm{Ni}$ & Rod tensile \\
\hline 10 & $9 \mathrm{Cr}-1 \mathrm{Mo}$ & Rod tensile \\
\hline 11 & $9 \mathrm{Cr}-1 \mathrm{Mo}-2 \mathrm{Ni}$ & Rod tensile \\
\hline 12 & $21 / 4 \mathrm{Cr}-1 \mathrm{Mo}$ & Rod tensile \\
\hline 13 & $12 \mathrm{Cr}-1 \mathrm{Mo}$ & Fattigue initiation \\
\hline
\end{tabular}

\subsubsection{Test Matrix and Irradiation Conditions for HFIR-MFE-RB 1}

This experiment will contain primarily ferritic steels. A list of alloys planned for inclusion in HFIR-MFE-RBl is given in Table 2.4.5 along with the alloy conditions, when known. The $C E^{-}$alloys are the same as those included in HFIR-MFE-T1 and $-\mathrm{T} 2$ and have been described in detail earlier. ${ }^{3}$ Two fluence levels are planned, as shown in Table 2.4.3. The flux will be roughly half that in HFIR-MFE-T1 and $-\mathrm{T} 2$ as a result of the capsule being located in the reflector position of HFIR. 
Table 2.4.5. Alloys for HFIR-MFE-RBI

\begin{tabular}{|c|c|c|}
\hline Alloy & Heat $a$ & Heat Treatment $b$ \\
\hline $12 \mathrm{Cr}-1 \mathrm{Mo}{ }^{c}$ & B $91354^{d}$ & $1038^{\circ} \mathrm{C}, 4 \mathrm{~min}, \mathrm{AC}+760^{\circ} \mathrm{C}, 30 \mathrm{~min}, \mathrm{AC}^{e}$ \\
\hline $12 \mathrm{Cr}-1 \mathrm{Mo} c$ & CE 3587 & $1050^{\circ} \mathrm{C}, 30 \mathrm{~min}, \mathrm{AC}+780^{\circ} \mathrm{C}, 2.5 \mathrm{~h}, \mathrm{AC}$ \\
\hline $12 \mathrm{Cr}-1$ Mo weld & B 91354 & $f$ \\
\hline $12 \mathrm{Cr}-1 \mathrm{Mo}-1 \mathrm{Ni}$ & CE 3588 & $1050^{\circ} \mathrm{C}, 30 \mathrm{~min}, \mathrm{AC}+780^{\circ} \mathrm{C}, 2.5 \mathrm{~h}, \mathrm{AC}$ \\
\hline $12 \mathrm{Cr}-1 \mathrm{Mo}-2 \mathrm{NI}$ & CE 3589 & $1050^{\circ} \mathrm{C}, 30 \mathrm{~min}, \mathrm{AC}+700^{\circ} \mathrm{C}, 5 \mathrm{~h}, \mathrm{AC}$ \\
\hline $9 \mathrm{Cr}-1 \mathrm{Mo}$ & B 30182 & $1038^{\circ} \mathrm{C}, 1 \mathrm{~h}, \mathrm{AC}+760^{\circ} \mathrm{C}, 1 \mathrm{~h}, \mathrm{AC}$ \\
\hline $9 \mathrm{Cr}-1 \mathrm{Mo}$ & CE 3590 & $1040^{\circ} \mathrm{C}, 30 \mathrm{~min}, \mathrm{AC}+760^{\circ} \mathrm{C}, 1 \mathrm{~h}, \mathrm{AC}$ \\
\hline $9 \mathrm{Cr}-1$ Mo weld & B 30182 & $f$ \\
\hline $9 \mathrm{Cr}-1 \mathrm{Mo}-2 \mathrm{N1}$ & CE 3591 & $1040^{\circ} \mathrm{C}, 30 \mathrm{~min}, \mathrm{AC}+700^{\circ} \mathrm{C}, 5 \mathrm{~h}, \mathrm{AC}$ \\
\hline $21 / 4 \mathrm{Cr}-1 \mathrm{Mo}$ & $g$ & \\
\hline $21 / 4 \mathrm{Cr}-1$ Mo weld & $g$ & \\
\hline Type 316 SS & $g$ & \\
\hline
\end{tabular}

$a_{\mathrm{B}}=$ breeder; $C E=$ Combustion Engineering.

$b_{\mathrm{AC}}=$ air cooled.

cSome material from a third heat of HT9 (the Fusion Program heat) may be included if the material is avallable in time.

$d_{\text {Heat }} 91353$ for fatigue initiation samples.

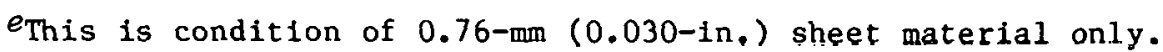
Heat treatment for thicker gage samples not yet determined.

$f_{\text {Not }}$ yet determined.

olat yet spectifed.

A tentative matrix for the samples to be irradiated to $10 \mathrm{dpa}$ is given in Table 2.4.6. The corresponding matrix of samples to renain for 20 dpa irradiation is presented in Table 2.4.7. The Charpy, crack growth, and compact tension specimens will be the first ferritic steel specimens of this type irradiated in HFIR and will correspond to sinilar irradiations in the EBR-II, $A D-2$ experiment.

According to the experimental design, some specimens will be removed after $10 \mathrm{dpa}$ irradiation. These will be replaced by additional samples intended for 10 dpa exposure during the second half of the experinent. The division of the matrix given in Table 2.4.6 into the first half and 
Table 2.4.6. Loading Matrix for the HFIR-MFE-RBI Specimens to Be Irradiated to $10 \mathrm{dpa}^{a}$

\begin{tabular}{|c|c|c|c|c|c|c|c|}
\hline \multirow{2}{*}{ Alloy } & \multirow{2}{*}{ Heat ${ }^{h}$} & \multicolumn{2}{|c|}{ Number of } & \multicolumn{2}{|c|}{ Specimens } & \multicolumn{2}{|c|}{ Each Type ${ }^{c}$} \\
\hline & & ST & FI & $\mathrm{CG}$. & $\mathrm{C}$ & $\mathrm{CT}$ & TEM \\
\hline $12 \mathrm{Cr}-1 \mathrm{Mo}$ & B 91354 & 4 & & 4 & 7 & 7 & 40 \\
\hline $12 \mathrm{Cr}-1 \mathrm{Mo}$ & CE 3587 & 4 & 3 & 3 & 4 & 4 & 25 \\
\hline $12 \mathrm{Cr}-1$ Mo weld & B $91354^{\circ}$ & & & 2 & 4 & 4 & \\
\hline $12 \mathrm{Cr}-1 \mathrm{Mo}-1 \mathrm{Ni}$ & CE 3588 & 4 & 3 & 3 & 4 & 4 . & 25 \\
\hline $12 \mathrm{Cr}-1 \mathrm{Mo}-2 \mathrm{Ni}$ & CE 3589 & 4 & 3 & 3 & 4 & 4 & 25 \\
\hline $9 \mathrm{Cr}-1 \mathrm{Mo}$ & В 30182 & 4 & & 3 & 7 & 7 & 40 \\
\hline $9 \mathrm{Cr}-1 \mathrm{Mo}$ & CE 3590 & 4 & 3 & 3 & 4 & 4 & 25 \\
\hline $9 \mathrm{Cr}-1$ Mo we $\mathrm{ld}$ & B 30182 & & & 2 & 4 & 4 & \\
\hline $9 \mathrm{Cr}-1 \mathrm{Mo}-2 \mathrm{Ni}$ & CE 3591 & 4 & 3 & 3 & 4 & 4 & 25 \\
\hline 2. $1 / 4 \mathrm{Cr}-1 \mathrm{Mo}$ & $d$ & 2 & & 3 & 4 & 4 & 40 \\
\hline $\begin{array}{l}21 / 4 \mathrm{Cr}-1 \text { Mo } \\
\text { weld }\end{array}$ & $d$ & & & 2 & 4 & 4 & \\
\hline Type 316. SS & $d$ & & & & 2 & 2 & . \\
\hline
\end{tabular}

$a_{\mathrm{A}}$ fluence producing $10 \mathrm{dpa}$ is the goal exposure for the experiment midplane.

$h_{\mathrm{B}}=$ breeder; $\mathrm{CE}=$ Combustion Engineering.

$c_{S T}=$ sheet tensile, $F I=$ fatigue initiation, $C G=$ crack growth, $\mathrm{C}=$ miniature Charpy, $\mathrm{CT}=$ fracture toughness, and $\mathrm{TEM}=$ transmission electron microscopy. Geometry in Table 2.4.1.

$d_{\text {Not }}$ yet specified.

second half 10-dpa irraditions is to be determined. The final breakdown will he affected by the packing efficiencies achieved. The matrix for the second half of the experiment may also be influenced by early results of the HFIR-MFE-T2 experiment. 
Table 2.4.7. Loading Matrix for the HFIR-MFE-RBl Specimens to be Irradiated to $20 \mathrm{dpa}^{a}$

\begin{tabular}{|c|c|c|c|c|c|c|c|}
\hline \multirow{2}{*}{ Alloy } & \multirow{2}{*}{ Heat $b$} & \multicolumn{2}{|c|}{ Number of } & \multicolumn{2}{|c|}{ Specimens of } & \multicolumn{2}{|c|}{ Each Type ${ }^{c}$} \\
\hline & & GF & FI & CG & $\mathrm{C}$ & $\mathrm{CT}$ & TEM \\
\hline $12 \mathrm{Cr}-1 \mathrm{Mo}$ & B $91354^{d}$ & 5 & 5 & 4 & 8 & 8 & 40 \\
\hline $12 \mathrm{Cr}-1 \mathrm{Mo}$ & CE 3587 & 3 & 3 & 3 & 4 & 4 & 25 \\
\hline $12 \mathrm{Cr}-1$ Mo weld & B 91354 & & & 2 & 4 & 4 & \\
\hline $12 \mathrm{Cr}-1 \mathrm{Mo}-1 \mathrm{Ni}$ & CE 3588 & 3 & 3 & 3 & 4 & 4 & 25 \\
\hline $12 \mathrm{Cr}-1 \mathrm{Mo}-2 \mathrm{Ni}$. & CE 3589 & 4 & 3 & 3 & 4 & 4 & 25 \\
\hline $9 \mathrm{Cr}-1$ Mo & B 30182 & 5 & 4 & 4 & 8 & 8 & 40 \\
\hline $9 \mathrm{Cr}-1 \mathrm{Mo}$ & CE 3590 & 3 & & 3 & 4 & 4 & 25 \\
\hline $9 \mathrm{Cr}-1$ Mo weld & B 30182 & & & 2 & 4 & 4 & \\
\hline $9 \mathrm{Cr}-1 \mathrm{Mo}-2 \mathrm{Ni}$ & CE 35991 & 3 & & 3 & 4 & 4 & 25 \\
\hline $21 / 4 \mathrm{Cr}-1$ Mo & $e$ & 4 & 3 & 3 & 4 & 4 & 40 \\
\hline $\begin{array}{l}21 / 4 \mathrm{Cr}-1 \text { Mo } \\
\text { weld }\end{array}$ & $e$ & & & 2 & 4 & 4 & \\
\hline Type 316 SS & $e$ & & & & 2 & 2 & \\
\hline
\end{tabular}

$a_{\mathrm{A}}$ fluence producing $20 \mathrm{dpa}$ is anticipated at the experiment midplane.

$b_{B}=$ breeder; $C E=$ Cumbustion Englneer1ng.

$c_{\mathrm{GF}}=$ Grodzinski. fatigue, $\mathrm{FI}=$ fatigue initiation, $\mathrm{CG}=$ crack growth, $\mathrm{C}=$ miniature Charpy, $\mathrm{CT}=$ fracture toughness, and $\mathrm{TEM}=$ transmission electron microscopy. Geometry in

Table 2.4.1.

$d_{\text {Hea }} 91353$ uōed for trl samples.

enot yet opceificd.

\subsubsection{Conclusions and Future Work}

Specimen preparation for HFIR-MFE-T1 and $-\mathrm{T} 2$ is currently under way. The test capsule is being constructed, and the experiments should be ready for insertion into $H H^{\prime} L \mathrm{~K}$ by December 1980. Preparation of materials for HFIR-MFE-RB1 is currently in progress and sample machining is expected to begin by November 1980. Insertion of the capsule into HFIR is expected in early 1981. 


\subsubsection{References}

1. M. L. Grossbeck and P. J. Maziasz, "Tensile Properties of HFIRIrradiated Types 316 and TiM 316 Stainless Steel at 200 to 1000 at. ppm He," ADIP Quart. Prog. Rep. Sept. 30, 1978, DOE/ET-0058/3, pp. 34-51.

2. R. J. Puigh and N. F. Panayotou, "Specimen Preparation and Loading for the AD-2 Ferritics Experiment," ADIP Quart. Prog. Rep. June 30, 1980, DOE/ER-0045/3, Pp. 278-79.

3. R. L. Klueh and J. M. Vitek, "Characterization of Ferritic Steels for HFIR Irradiation," ADIP Quart. Prog. Rep. June 30, 1980, DOE/ER-0045/3, pp. $294-308$. 
2.5 EXPERIMENTS HFIR-CTR-30; -31, AND -32 FOR IRRADIATION OF TRANSMISSION ELECTRON MICROSCOPY DISK SPECIMENS - M. L. Grossbeck, J. W. Woods, and G. A. Potter (ORNL)

\subsubsection{ADIP Task}

ADIP Task I.A.2, Define Test Matrices and Test Procedures.

\section{5 .2 Objective}

This experiment is designed to determine the effect of irradiation producing high helium contents with concurrent displacement damage $n$ the microstructure and ductility of several alloys in the ADIP program.

\subsubsection{Summary}

Three irradiation capsules containing exclusively transmission electron microscopy (TEM) disk specimens have been constructed for High Flux Isotope Reactor (HFIR) irradiation. Experiments HFIR-CTR-30 and -32 are now being irradiated, and HFIR-CTR-31 is scheduled for insertion on October 1, 1980. All capsules are being irradiated in peripheral target positions in the HFIR. The 12 groups of approximately 100 specimens each are arrayed along the capsule axis of each experiment. Each group is designed to be isothermal at an elevated temperature deterinined by a helium gas gap. Irradiation temperatures of 300,400 , 500 , and $600^{\circ} \mathrm{C}$ have been selected.

\subsubsection{Progress and Status}

Since the ADIP program must evaluate and compare alloys under condiclons of neutron irradiation producing both displacement damage and transmutation helium, an experiment was designed to investigate the microstructure and ductility of candidate fusion alloys. After irradiation, two typco of exaininatious will be lidde un the spccimens: microstructural determination and ductility measurement. Ductility will be measured with a punch and die apparatus developed by Huang, 1 which fits on a standard tensile testing machine. Such tests have been shown to give qualitative results and to work well on brittle materials. It is 
useful to scope developmental alloys when limited irradiation space dictates small specimens. Microstructural determination will be by TEM.

\subsubsection{Irradiation Conditions}

The irradiation is being conducted in peripheral target positions of the HFIR, which permits exposure to the highest fast flux possible for an experiment in the HFIR, $1.3 \times 10^{19}$ neutrons $/\left(\mathrm{m}^{2} \cdot \mathrm{s}\right)[>0.1 \mathrm{MeV}(0.016 \mathrm{pJ})]$. Exposure times, displacements per atom (dpa), and helium levels to be attained at the core midplane are given in Table 2.5.1.

Table 2.5.1. Irradiation Parameters for Type 316 Stainless Steel

\begin{tabular}{lccc}
\hline Experiment & $\begin{array}{c}\text { Exposure } \\
\text { Time } \\
\text { (months) }\end{array}$ & $\begin{array}{c}\text { Displacement } \\
\text { (dpa) }\end{array}$ & $\begin{array}{c}\text { He Level } \\
\text { (at. ppm) }\end{array}$ \\
\hline HFIR-CTR-30 & 16 & 40 & 2500 \\
HFIR-CTR-31 & 8 & 20 & 1200 \\
HFIR-CTR-32 & 4 & 10 & 500 \\
\hline
\end{tabular}

Irradiation temperature was determined with the HEATING5 twodimensional heat transfer computer $\operatorname{code}^{2}$ used in previous HFIR capsule designs. The design was iterated until the specimen temperature in each specimen holder was within $\pm 20^{\circ} \mathrm{C}$ of the desired value throughout. Typical temperature contour plots are shown in Fig. 2.5.1. Silicon carbide disks and low-melting alloys were used to monitor temperature. The placement of the temperature monitors is shown in Table 2.5.2. Since SiC has a much lower density than the alloys, its nuclear heating value is significantly lower, resulting in a drop in temperature adjacent to the monitors. This drop is usually small and can be accounted for in computing the actual irradiation temperatures. 


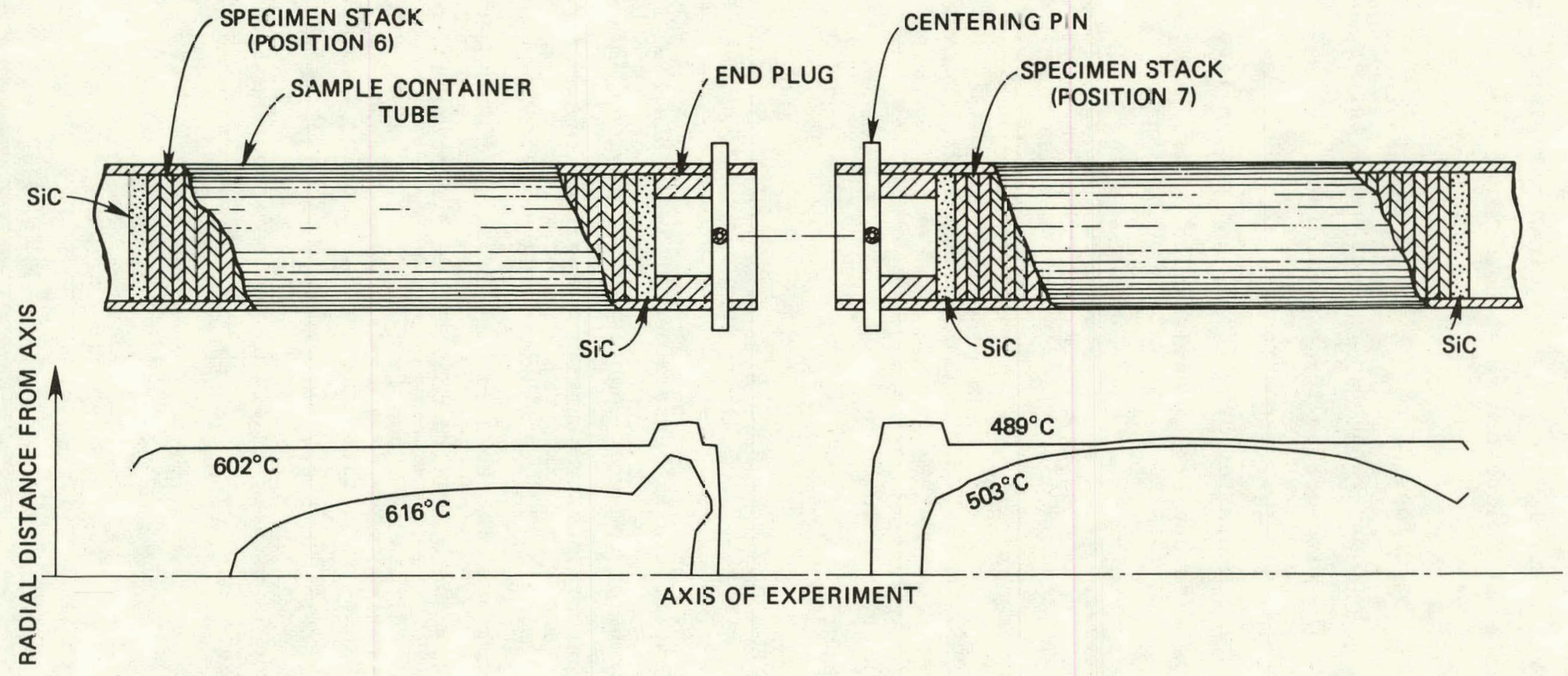

Fig. 2.5.1. Temperature Contours for Positions 6 and $7\left(600\right.$ and $\left.550^{\circ} \mathrm{C}\right)$. The top half of the figure shows the schematic loading of the adjacent halves of the two positions. Shown below are the temperature contours near the design temperatures. 
Table 2.5.2. Placement of Temperature Monitors in HFIR-CTR-30

\begin{tabular}{|c|c|c|c|}
\hline $\begin{array}{l}\text { Specimen } \\
\text { Holder }\end{array}$ & $\begin{array}{c}\text { Design } \\
\text { Temperature } \\
\left({ }^{\circ} \mathrm{C}\right)\end{array}$ & $\begin{array}{l}\text { Monitor } \\
\text { Alloy }\end{array}$ & $\begin{array}{l}\text { Monitor Melting } \\
\text { Temperature } \\
\left({ }^{\circ} \mathrm{C}\right)\end{array}$ \\
\hline 1 & 400 & $\begin{array}{l}\mathrm{SiC} \quad(2) \\
\mathrm{Zn}-\mathrm{Al} \\
\mathrm{Zn}\end{array}$ & $\begin{array}{l}382 \\
420\end{array}$ \\
\hline 2 & 600 & $\mathrm{SiC}$ (3) & \\
\hline 3 & 400 & $\begin{array}{l}\mathrm{Zn}-\mathrm{Al} \\
\mathrm{SiC}(3)\end{array}$ & 382 \\
\hline 4 & 600 & $\mathrm{SiC}$ (4) & \\
\hline 5 & 400 & $\begin{array}{l}\mathrm{SiC} \\
\mathrm{Zn}-\mathrm{A} 1 \\
\mathrm{Zn}\end{array}$ & $\begin{array}{l}382 \\
420\end{array}$ \\
\hline 6 & 600 & $\mathrm{SiC}$ & \\
\hline 7 & 500 & $\begin{array}{l}\mathrm{SiC} \\
\mathrm{Ni}-\mathrm{Mg} \\
\mathrm{Cu}-\mathrm{Al}\end{array}$ & $\begin{array}{l}507 \\
548\end{array}$ \\
\hline 8 & 300 & $\begin{array}{l}\mathrm{SiC} \\
\mathrm{Pb} \\
\mathrm{Pb}-\mathrm{Pt}\end{array}$ & $\begin{array}{l}327 \\
290\end{array}$ \\
\hline 9 & 500 & $\begin{array}{l}\mathrm{SiC}(4) \\
\mathrm{Ni}-\mathrm{Mg} \\
\mathrm{Cu}-\mathrm{Al}\end{array}$ & $\begin{array}{l}507 \\
548\end{array}$ \\
\hline 10 & 300 & $\begin{array}{l}\mathrm{Pb}-\mathrm{Pt} \\
\mathrm{Pb} \\
\mathrm{SiC} \quad(4)\end{array}$ & $\begin{array}{l}290 \\
327\end{array}$ \\
\hline 11 & 500 & $\begin{array}{l}\mathrm{SiC} \\
\mathrm{Ni}-\mathrm{Mg} \\
\mathrm{Cu}-\mathrm{Al} \\
\mathrm{Cu}-\mathrm{Mg}\end{array}$ & $\begin{array}{l}507 \\
548 \\
485\end{array}$ \\
\hline 12 & 300 & $\operatorname{SiC}(4)$ & \\
\hline
\end{tabular}

a Position 1 is top of the experiment.

$b_{\text {Number }}$ in parentheses indicates number of SiC disks in the specimen holder. 


\subsubsection{Capsule Design}

The external capsule is the same as used for previous HFIR irradiations. ${ }^{3}$ The internal structure consists of 12 specimen holders arrayed in tandem along the capsule axis. These holders consist of a thin tube containing the specimens, with hollow pins retaining the specimens and centering the tube within the outer aluminum holder (Fig. 2.5.2). The gas gap between the specimen tube and the holder sets the temperature gradient that achieves the irradiation temperature.

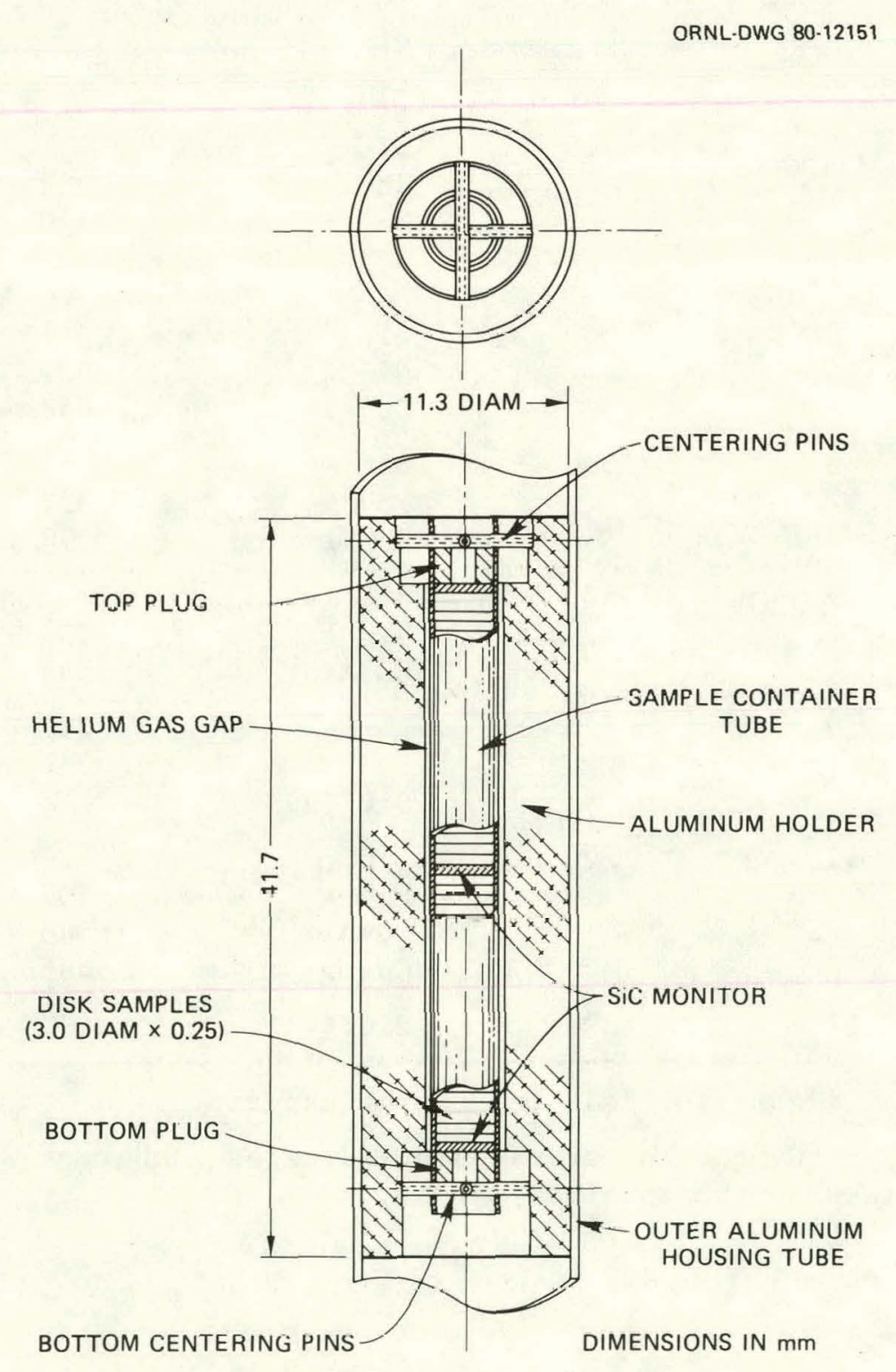

Fig. 2.5.2. Specimen Holder. 


\subsubsection{Specimen Loading}

For specimen loading, the capsule was divided into three regions by neutron flux. The general plan was to place low-nickel and Path A alloys in the central four positions. Path B alloys with less than $40 \% \mathrm{Ni}$ are in the next four positions moving outward from the midplane in both directions, and those with at least $40 \% \mathrm{Ni}$ are placed in the end four positions. Space considerations dictated some exceptions to this placement. The actual alloy placement is shown in Fig. 2.5.3, and numbers of specimens of each alloy are shown in Tables 2.5.3 through 2.5.5. Variations in heat treatment and composition are not distinguished in this report. Tables 2.5.3 through 2.5 .5 are specifically for HFIR-CTR-30; however, HFIR-CTR-31 and -32 differ only slightly because of availability of specimens and temperature monitors.

ORNL-DWG 80.12153
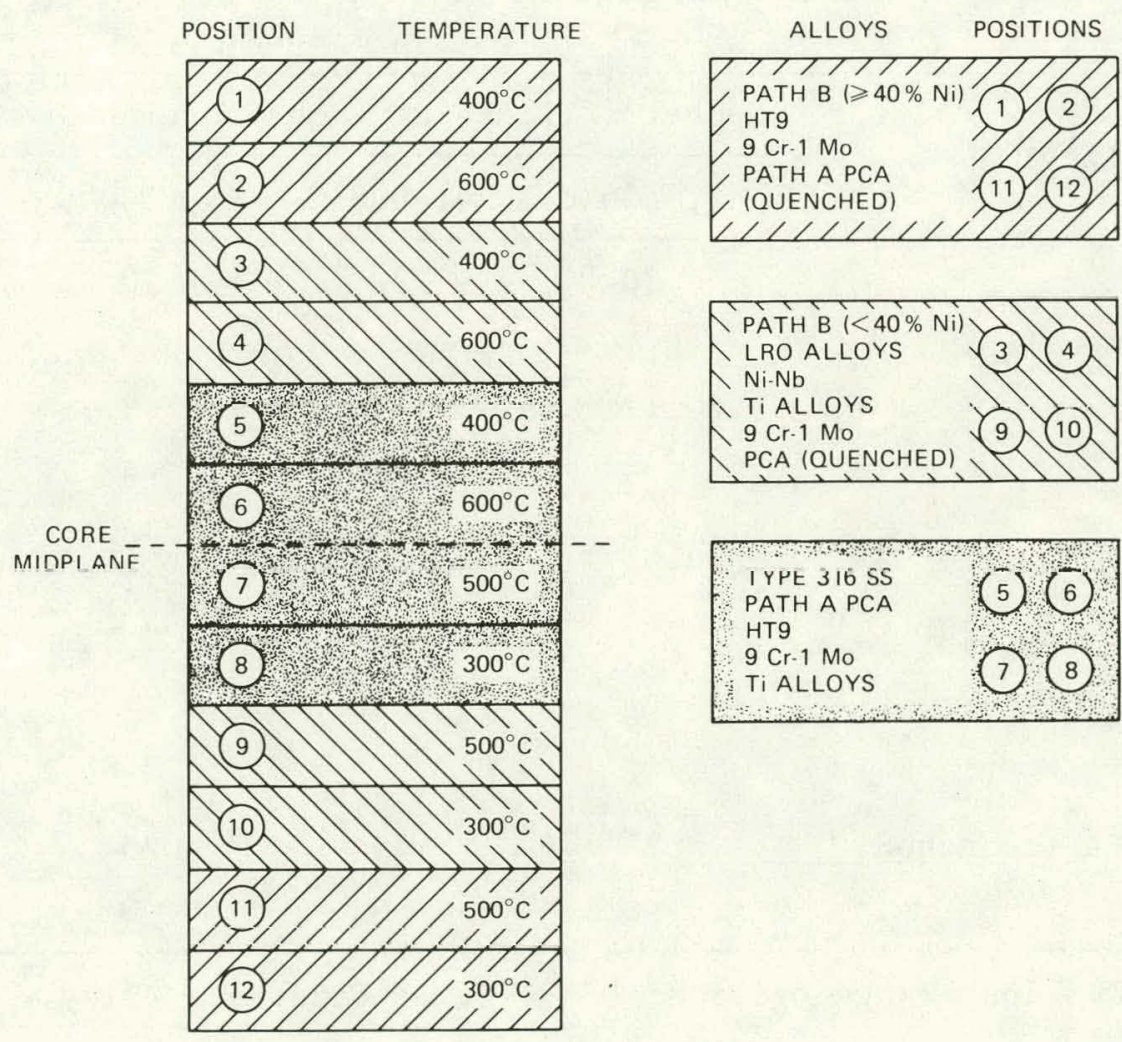
Capsule.

Fig. 2.5.3. Temperature and Alloy Distribution in the Irradiation 
Table 2.5.3. Number of Disks of Each Alloy in the Low-Flux Regions of HFIR-CTR-30

\begin{tabular}{lccccc}
\hline & & \multicolumn{2}{c}{ Nunber of Disks at Each Position and Temperature } \\
\cline { 2 - 5 } & $1,400^{\circ} \mathrm{C}$ & $2,600^{\circ} \mathrm{C}$ & $11,500^{\circ} \mathrm{C}$ & $12,300^{\circ} \mathrm{C}$ \\
\hline B2 & 16 & 16 & 16 & 16 \\
B4 & 16 & 16 & 16 & 16 \\
B6 & 12 & 12 & 12 & 12 \\
HT9 & 20 & 20 & 20 & 20 \\
9 Cr-1 Mo & 20 & 20 & 20 & 20 \\
Path A PCAa (quencher) & 4 & 23 & 0 & 23 \\
\hline
\end{tabular}

arime Candidate Alloy.

Table 2.5.4. Number of Disks of Each Alloy in the Medium-Flux Regions of HFIR-CTR-30

\begin{tabular}{lccccc}
\hline & \multicolumn{2}{c}{ Number of Disks at Each } & Position and Temperature \\
\cline { 2 - 5 } & $3,400^{\circ} \mathrm{C}$ & $4,600^{\circ} \mathrm{C}$ & $9,500^{\circ} \mathrm{C}$ & $10,300^{\circ} \mathrm{C}$ \\
\hline B1 & 20 & 20 & 20 & 19 \\
B2 & 5 & 1 & 5 & 5 \\
B3 & 19 & 19 & 19 & 19 \\
LRO 16 & 4 & 4 & 4 & 4 \\
LRO 20 & 4 & 4 & 4 & 4 \\
LKU 35 & 4 & 4 & 4 & 4 \\
LRO 37 & 4 & 4 & 4 & 4 \\
Ti-6 Al-4 V & 6 & 6 & 6 & 6 \\
Ni-Nb & 4 & 3 & 3 & 3 \\
Path A PCA (quenched) & 25 & 25 & 25 & 25 \\
9 Cr-1 Mo & 6 & 0 & 0 & 0 \\
\hline
\end{tabular}


Table 2.5.5. Number of Disks of Each Alloy in the High-Flux Regions of HFIR-CTR-30

\begin{tabular}{lccccc}
\hline \multirow{2}{*}{ Alloy } & Number of & Disks at Each & Position and & Temperature \\
\cline { 2 - 5 } & $5,400^{\circ} \mathrm{C}$ & $6,600^{\circ} \mathrm{C}$ & $7,500^{\circ} \mathrm{C}$ & $8,300^{\circ} \mathrm{C}$ \\
\hline Type $316 \mathrm{SS}$ & 12 & 12 & 12 & 12 \\
Path A PCA $a$ & 24 & 24 & 24 & 24 \\
HT9 & 20 & 20 & 20 & 20 \\
9 Cr-1 Mo & 18 & 18 & 18 & 18 \\
Ti $5621 \mathrm{~S}$ & 2 & 2 & 2 & 2 \\
Ti $6242 \mathrm{~S}$ & 2 & 2 & 2 & 2 \\
Ti 38644 & 2 & 2 & 2 & 2 \\
Ti $38644 \mathrm{Ni}$ & 2 & 2 & 2 & 2 \\
\hline
\end{tabular}

arime Candidate Alloy.

The materials are almost entirely standard alloys of the ADIP program. Chemical compositions may be obtained from the ADIP Materials Inventory records or from the final progress report 4 on ORR-MFE-4.

\subsubsection{Conclusions}

Three neutron irradiation experiments encompassing specimens from all ADIP alloy paths have been prepared to determine microstructure and ductility. The HFIR was selected to study. the effects of both displacement damage and large quantities of transmutation-induced helium. Two capsules, HFIR-CTR-30 and -32 , are now in the reactor; HFIR-CTR-31 is scheduled for insertion on October $1,1980$.

\subsubsection{References}

1. Private communication, F. F. Huang, Hanford Engineering Development Laboratory, to M. L. Crosobcck, ORNL, 1979.

2. W. D. Turner, D. C. Elrod, and I. I. Siman-Tov, HEATING5 - An IBM 360 Heat Conduction Program, ORNL/CSD/TM-15 (March 1977). 
3. M. L. Grossbeck and M. J. Kania, "HFIR Irradiation of Hourglass Fatigue Specimens," ADIP Quart. Prog. Rep. Jan.Mar. 1978, DOE/ET-0058/2, pp. 20-35.

4. M. L. Grossbeck and K. R. Thoms, "ORR-MFE-4: A Spectral Tailoring Experiment to Simulate the He/dpa Ratio of a Fusion Reactor in Austenitic Stainless Steels," ADIP Quart. Prog. Rep. June 30, 1980, DOE/ER-0045/3, pp. 10-23. 
2.6 MEASUREMENTS OF THE FATIGUE PRE-CRACKED LENGTH OF FRACTURE TOUGHNESS SPECIMENS USING AN ELECTROPOTENTIAL TECHNIQUE - F. H. Huang, G. L. Wire (Hanford Engineering Development Laboratory).

\subsubsection{ADIP Task}

ADIP Task 1.B.5.1 "Development Specimens and Test Methods."

\subsubsection{Objective}

The objective of this work is to develop a single specimen method, using electropotential techniques for fracture toughness measurements on miniature specimens of HT-9. The techniques are used to study the fracture behavior of fusion first wall materials.

\subsubsection{Summary}

HT-9 fracture toughness specimens were fatigue precracked using an electropotential technique to monitor the precrack length. A calibration curve was developed from optical crack measurements. Test results produced by this technique are shown to be as accurate as these obtained by optical methods.' The technique will be used in the hot-cell to replace the tedious optical method.

\subsubsection{Progress and Status}

Elastic/plastic fracture mechanics has been used to study the uppershelf ductile fracture behavior of ferritic steels. Because of limited irradiation space, efforts have been made to develop a single specimen method for fracture toughness testing. ${ }^{1}$ The basic requirement for a single specimen method is the capability of measuring crack extension continuously so that $J_{C}$ can be determined from a single specimen.

All fracture toughness test specimens were fatigue precracked to ublain a sharp crack t1p. In the previous tests, the precrack length was measured by a traveling microscope. The method is tedious and time consuming when used in hot-cells.

In this work, the electropotential technique developed for fracture toughness testing was applied to the precracking of the fracture toughness 
specimens. A schematic diagram of the HT-9 specimen (2.54 mm thick) is shown in Figure $1(a)$ and the position of the current input and potential measurement leads are shown in Figure 1(b). Specimens were precracked below a stress intensity factor of $28 \mathrm{MPa} \sqrt{\mathrm{m}}$ using a servo-hydraulic system at room temperature. The potential changes and their corresponding crack lengths were measured simultaneously. The measurements are shown in Figure 2 and Figure 3 in the forms of $V / V_{0}$ versus $a / a_{0}$ and $V / V_{0}$ versus $a / w$ where $V_{0}$ is the initial potential drop across the initial crack length $a_{0}$ and $w$ is the width of the specimen referenced to the load line center. The consistency of the data indicates that the precrack length can be measured accurately from the potential drop across the crack length. Al though the slope of the calibration curve is a function of current lead and potential probe positions, the overall shapes of the calibration curve shown in Figure 2 are consistent with those calculated by finite element analysis for compact tension specimens. ${ }^{2}$

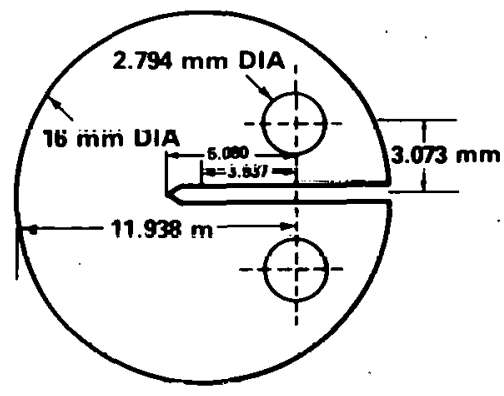

(a)

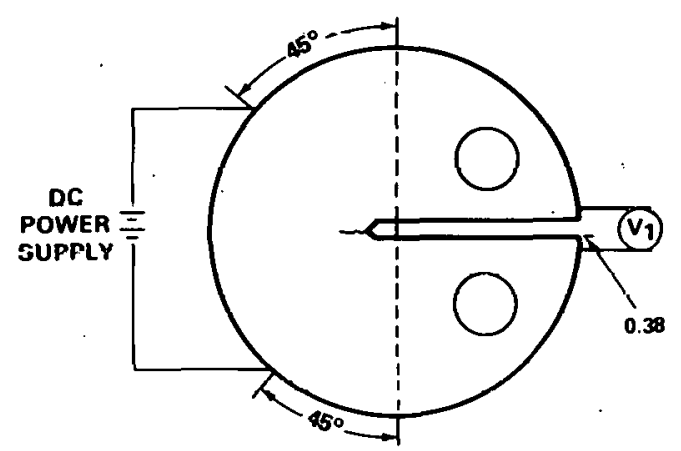

(b)

FIGURE 1(a) Circular Compact l'est Specimens of HT-9. FIGURE 1(b) Schematic Drawing of Electropotential Technique.

As discussed previously, (1) the calibration curve of fatigue cracked specimens whose crack fronts are nearly straight differs from that obtained from interrupted test specimens which have curved crack fronts, except in the blunting portion. As can be seen from Figure 3, the slope of the calibration curve for specimens with curved crack fronts is smaller than that for fatigue precracked specimens. This is due to a larger potential change 


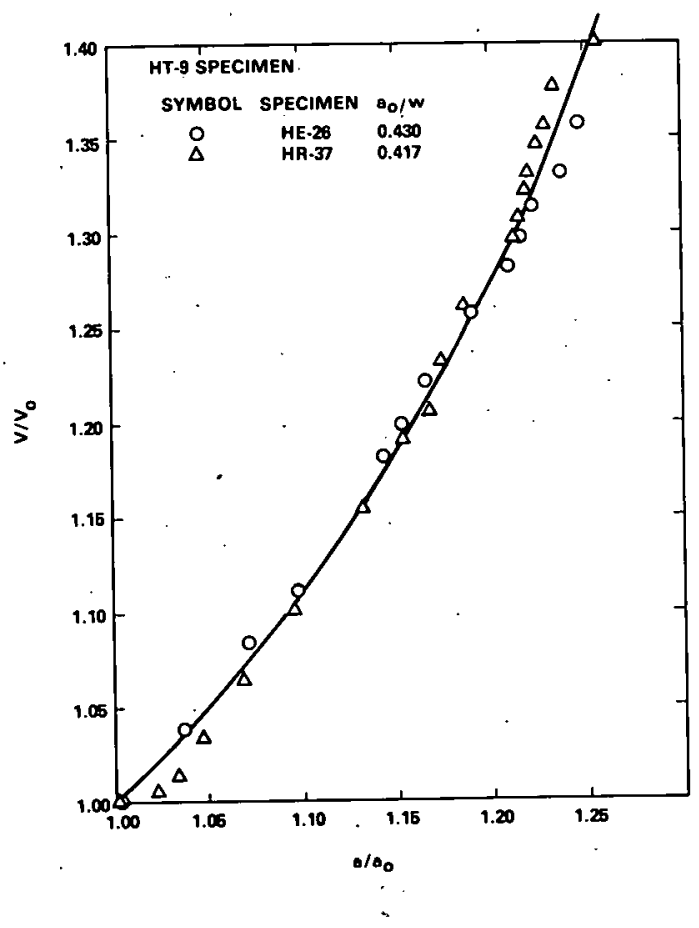

FIGURE 2. Electropotential Calibration Curve $V / V$ Versus $a / a_{0}$ for the Fatigue Precracking of HT-9 Specimen at $25^{\circ} \mathrm{C}$.

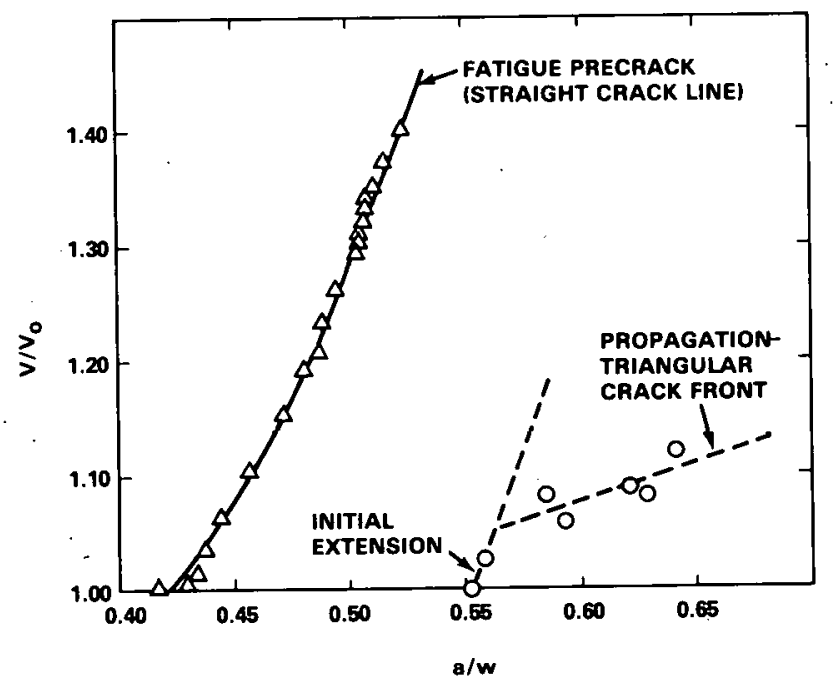

FIGURE 3. Electropotential Calibration Curve $V / V$ versus a/w for the Fat.igue Precracking and Interrupted Testing of HT-9 Specimens at $25^{\circ} \mathrm{C}$. 
resulting from a larger crack area advanced for fatigue pre-cracked specimens. In the blunting region, the crack front is believed to be straight and the material fractures in a manner similar to the later portion of fatigue precracking. As soon as the crack initiation occurs, the crack front becomes curved and the rate of potential change with respect to the crack extension is reduced. This significant observation explains the two slope calibration curve observed in previous work. In Figure 4, the calibration curves of $\mathrm{V} / \mathrm{V}_{\mathrm{O}}$ versus $\mathrm{A} / \mathrm{A}_{\mathrm{O}}$ for fatigue precracking and fracture toughness, where A is crack extension arèa, are plotted for comparison.

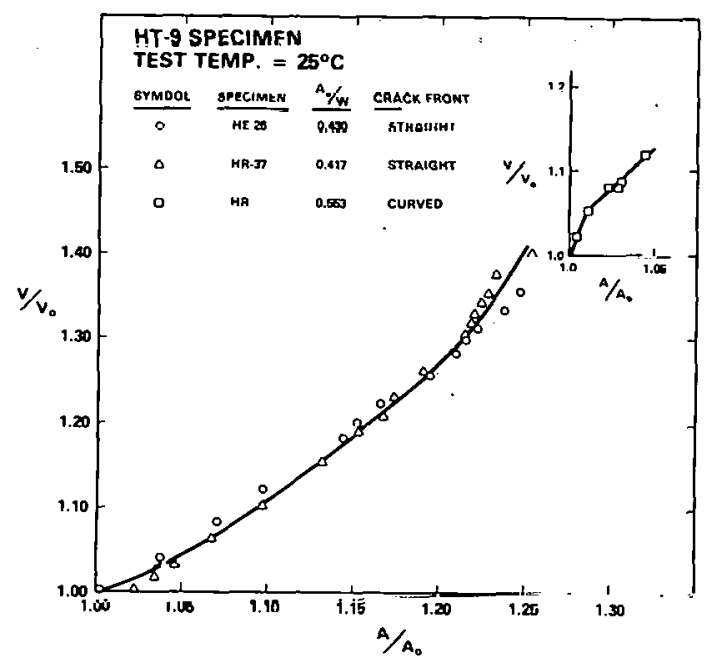

FIGURE 4. Electropotential Calibration Curve V/V. Versus A/A for Fiti.icur Precracking and fracturc toughness of $\mathrm{HT}-9$ Specimens at $25^{\circ} \mathrm{C}$.

\subsubsection{Conclusions}

The monitoring of the prccrack letiyll of fracturc toughness specimens using an electropotential technique has heen proven fcaoiblc. The Lecliw nique is particularly useful for in-cell testing, for it eliminates the need for the tedious optical precracking measurements. In addition, both precracking and testing of fracture toughness specimens can be conducted on one hydraulic testing system using electropotential techniques. 


\subsubsection{References}

1. F. H. Huang and G. L.' Wire, "Analysis of Single Specimen Tests on HT-9 for J $1 c$ Determination," ADIP Quarterly Progress Report, AprilJune, 1980 .

2. G. H. Aronson and R. O. Ritchie, "Optimization of the Electrical Potential Technique for Crack Growth Monitoring in Compact Test Pieces Using Finite Element Analysis," ASTM, J. of Testing and Evaluation, Vol. 7, No. 4, p. 208, 1979. 
2.7 STATUS OF MFE-5 IN-REACTOR FATIGUE CRACK GROWTH EXPERIMENT A. M. Ermi (Hanford Engineering Development Laboratory)

\subsubsection{ADIP Task}

ADIP Task I.B.1, "Fatigue Crack Growth in Austenitic Alloys" (Path A).

\subsubsection{Objectives}

An apparatus has been developed to perform in-reactor fatigue crack propagation tests on the Path A Reference Alloy. Effects of dynamic irradiation on crack growth behavior will be evaluated by comparing the results with those of unirradiated and postirradiated tests.

\section{7 .3 Summary}

Fabrication of the in-reactor fatigue machine to be used in MFE-5 is completed. The assembly has been delivered to ORNL as final preparations are underway for a November insertion. Modification of the prototypic fatigue machine, to be used in the thermal control test at HEDL, is in progress.

\subsubsection{Progress and Status}

\subsubsection{Introduction}

Fatigue crack propagation (FCP) in the first wall of a magnetic fusion reactor may be a limiting quantity governing reactor lifetimes. Previous studies of irradiation effects on FCP have all been conducted out of reactor on materials preirradiated in the unstressed condition. The ORR-MFE-5 experiment will investigate FCP during irradiation, where dynamic irradiation may effect crack growth characteristics.

\subsubsection{In-Reactor FCP Test at ORNL}

The pneumatic actuated fatigue machine designed to perform inreactor FCP tests was described previously. $(1,2)$ Briefly, it is 
designed to perform tension-tension cycling on a chain of up to eight miniature center-cracked-tension (CCT) specimens. The test will be conducted in sodium to maintain a temperature of $425^{\circ} \mathrm{C}$, and will be cycled at a frequency of $1 \mathrm{cpm}$.

At a preliminary review in July, the ORNL Reactor Experiments Review Committee accepted the containment design for MFE-5. Their acceptance was contingent on the issuance of final drawings which correspond to the design analysis. In September, fabrication of the test assembly was completed and the hardware and drawings were delivered to the ORR. Installation of the experiment support equipment and safety instruments are underway in preparation for insertion during the November reactor shutdown period.

\subsubsection{Thermal Control Test at HEDL}

Shortly after the in-reactor test is started at ORNL, a thermal control test will be initiated at HEDL. This test will duplicate the load-temperature history of the in-reactor experiment. The thermal control test will be conducted on the prototypic fatigue machine which was earlier used to demonstrate the viability of a pneumatically operated tester. $(3,4)$

The final test matrix for both the in-reactor and thermal control tests is outlined in Table 2.7.1. Based on the individual starting crack length values, the initial stress intensity factor range $\left(\Delta \mathrm{K}_{i}\right)$ for each specimen was computed by: (5)

$$
\begin{aligned}
\Delta K & =(1-R)(P \sqrt{\pi a} \cdot / t W)\left[1-0.025(2 a / W)^{2}\right. \\
& \left.+0.06(2 a / W)^{4}\right][\sec (\pi a / W)]^{1 / 2}
\end{aligned}
$$

where

$$
\begin{aligned}
& \mathrm{R}=\text { stress ratio } \\
& \mathrm{P}=\text { maximum load } \\
& \mathrm{a}=\text { half-crack length } \\
& \mathrm{t}=\text { specimen thickness } \\
& \mathrm{W}=\text { specimen width }
\end{aligned}
$$


TABLE 2.7 .1

TEST MATRIX FOR THE ORR-MFE-5 EXPERIMENT

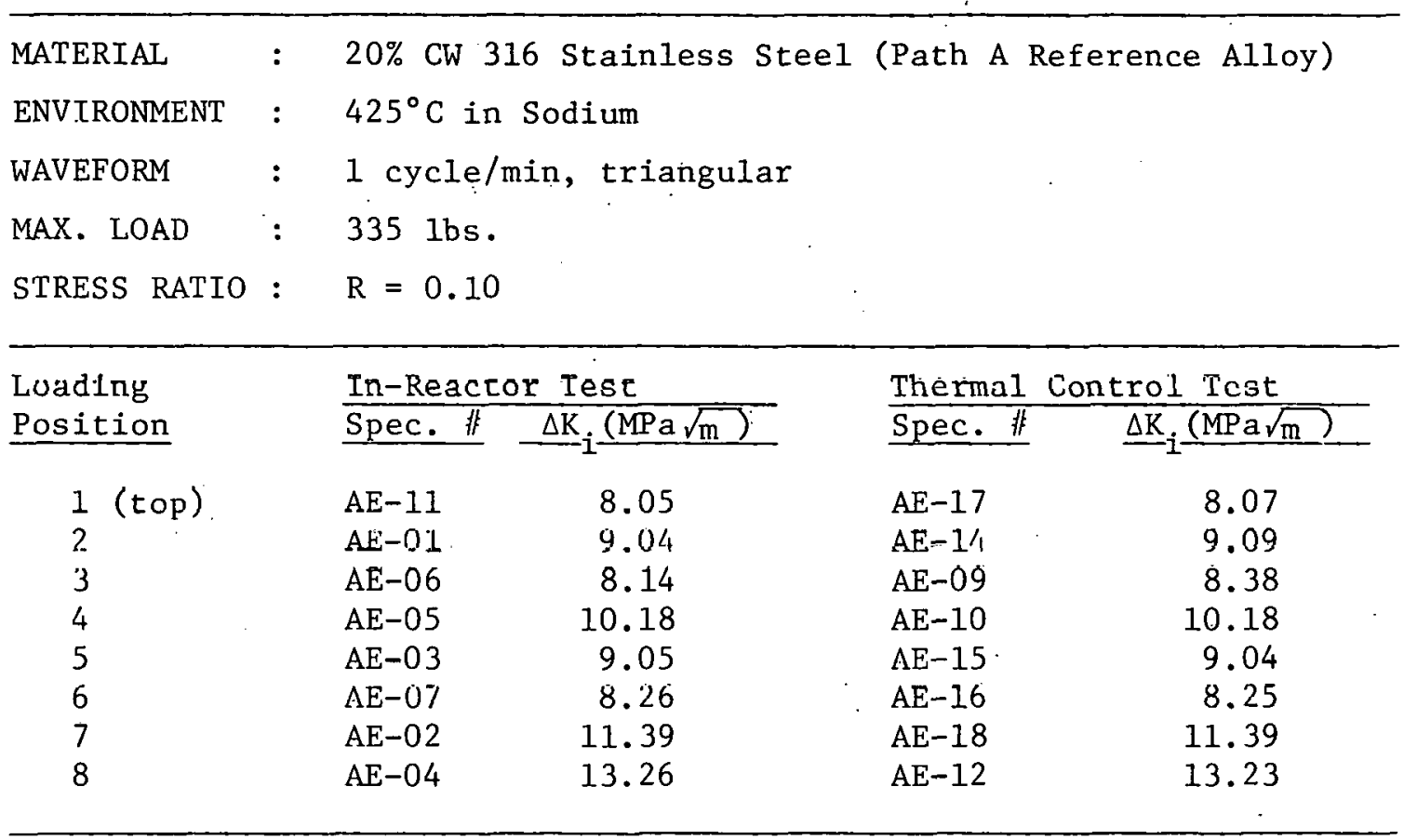

The test will be run until either: (a) the specimen in loading position 8 in one of the chains completely separates; or (b) the test has accumulated $\sim 200,000$ cycles (approximately six months).

\subsubsection{Conclusions}

(a) 'lhe in core hardware for $\mathrm{MEE}-5$ has been approved by ORNL reactor safety committee.

(b) The test assembly and experiment support equipment have been delivered to ORNL and are undergoing installation and check-out. (c) 'l'he prototype fatigue machine is being modified in preparation for the thermal control test at HEDL.

\subsubsection{Future Work}

Insertion and startup of MFE-5 is scheduled for the November, 1980 reactor shutdown period. The thermal control test will be started two to four weeks later at HEDL. 


\subsubsection{References}

1. A. M. Ermi, "Status of an In-Reactor Fatigue Crack Growth Experiment", ADIP Quarterly Progress Report, June 30, 1979, DOE/ ET-0058/6, pp. 28-34.

2. A. M. Ermi, "Results of Prototypic Testing for the MFE-5 InReactor Fatigue Crack Propagation Experiment", ADIP Quarterly Progress Report, September 30, 1979, DOE/ET-0058/7, pp. 50-65.

3. A. M. Ermi, "Prototype Testing of MFE-5 In-Reactor Fatigue Crack Growth Experiment", ADIP Quarterly Progress Report, March 31, 1980, DOE/ER-0045/2, pp. 6-13.

4. A. M. Ermi, "Fatigue Crack Growth Testing of 316 SS for MFE-5", ADIP Quar.terly Progress Report, June 30, 1980, DOE/ER-0045/3.

5. H. Tada, P. Paris, G. Irwin, "The Stress Analysis of Cracks Handbook", Del Research Corporation, Hellertown, Pennsylvania (1973). 
2.8 SPECIMEN MATRIX FOR THE HFIR IRRADIATION OF THE PATH B ALLOYS D. T. Peterson (Hanford Engineering Development Laboratory)

\subsubsection{ADIP Task}

ADIP Task I.C.3, Microstructure and Swelling in High Strength/High Temperature Fe-Ni-Cr Alloys (Path B).

\subsubsection{Objective}

The objective of this work is to assess the irradiation response of the path $\mathrm{B}$ base research alloys in a high helium environment.

\section{8 .3 Summary}

Specimens of the path B alloys, in the form of TEM disks, have been included in the HFIR experiments designated HFIR-CTR-30, 31, and 32 . These irradiations will provide the first data on the irradiation response of the path B base research alloys.

\section{8 .4 Progress and Status}

\subsubsection{Introduction}

The Fe-Ni-Cr superalloys were developed as high strength materials for high temperature applications such as gas turbine components. The precipitation reactions in these alloys provide them with mechanical properties superior to the austenitic stainless steels. In recent years several alloys in this class have been found to be very swelling resistant during fast reactor irradiations. Their superior mechanical. properties and swelling resistance have led to the consideration of these alloys for fusion reactor first wall applications.

The path $B$ base research alloys (B1, B2, B3, B4, and B6) were developed to scope several subclasses of the Fe-Ni-Cr superalloys. Alloys B1 and B2 are molybdenum-modified, $\gamma^{\prime}$-strengthened alloys, with B2 being similar to Nimonic PE16; alloy B3 is a niobium-modified, $\gamma^{\prime}$-strengthened alloy; alloy $B 4$ is a $\gamma^{\prime} / \gamma^{\prime \prime}$-strengthened alloy similar to Inconel 706; and alloy $\mathrm{B} 6$ is a high nickel, $\gamma^{\prime}$-strengthened alloy similar to Inconel $\mathrm{X}-750$. 


\subsubsection{Materials}

The path $B$ alloys used in this work are from the MFE heats listed in Table 2:8.1. The materials were received from ORNL in the form of $0.6 \mathrm{~mm}$ thick sheet stock in the $50 \%$ cold worked condition. The fabrication history of this material is detailed in reference 1.

TABLE 2.8 .1

MFE HEAT NUMBERS

Alloy $\quad$ Heat Number

$\begin{array}{ll}\text { B1 } & \mathrm{J}-271-1 \\ \text { B2 } & \mathrm{J}-268-2 \\ \text { B3 } & \mathrm{J}-267-1 \\ \text { B4 } & \mathrm{J}-264-1 \\ \text { B6 } & \mathrm{J}-262-1\end{array}$

Sections of the as-received sheets were given an anneal of $1025^{\circ} \mathrm{C} /$ $5 \mathrm{~min} / \mathrm{AC}$ and cold rolled in two stages to $0.25 \mathrm{~mm}$. An intermediate anneal of $1025^{\circ} \mathrm{C} / 5 \mathrm{~min} / \mathrm{AC}$ was used between the two reduction steps. TEM disks were punched from the as-rolled sheet. For heat treatment the specimens were encapsulated with a piece of tantalum foil in an evacuated quartz ampule backfilled with one-quarter atmosphere of argon.

\subsubsection{Tesl Matrix}

A set of three irradation assemblies, designated HFIR-CTR-30; 31 , and 32, recently began irradiation in HFIR. These assemblies will be irradiated to goal fluences of 10, 20, and $40 \mathrm{dpa}$, respectively. Each assembly conta1ns specimens at irradiation temperatures of $300,400,500$, and $600^{\circ} \mathrm{C}$.

The specimens included in these assemblies are TEM disks present with a multiplicity of five. Each of the five path $B$ alloy is being irradiated in three thermomechanical treatments. Also included in these irradiations are specimens, provided by the DAFS program, of the path $B$ alloys in solution treated and aged conditions. ${ }^{2}$ 


\subsubsection{Future Work}

The discharge of HFIR-CTR-30, at a fluence of $10 \mathrm{dpa}$, is expected to occur early in 1981. At that time a critical assessment of the irradiation response of the path $B$ alloys will be performed to determine if they warrant further developmental effort.

\subsubsection{References}

1. T. K. Roche, "Status of Path B Base Research Alloy Procurement and Fabrication," ADIP Quarterly Progress Report, January-March, 1979.

2. D. T. Peterson and R. W. Powell, "HFIR Irradiation of Representative Path B Alloys," DAFS Quarterly Progress Report, Apri1-June, 1,980. 


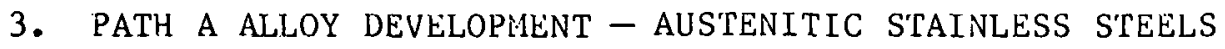


3.1 HIGH-TEMPERATURE FATIGUE CRACK PROPAGATION TESTING OF TYPE 316 STAINLESS STEEL IN VACUUM - H. H. Smith and D. J. Miche1 (Naval Research Laboratory)

Lost in transit. 
3.2 MINIATURE TENSILE TESTING OF 316 STAINLESS STEEL - R. J. Puigh and E. K. Opperman (Hanford Engineering Development Laboratory)

\subsubsection{ADIP Task}

The Department of Energy (DOE), Office of Fusion Energy (OFE) has cited the need for these data under the ADIP Program Task I.B.13, "Tensile Properties of Austenitic Alloys".

\subsubsection{Objective}

The objective of this work is to develop a miniature tensile specimen technology in support of high energy neutron irradiated material testing. This work includes the development of specimen fabrication techniques and both baseline and irradiated tensile testing of these specimens.

\subsubsection{Summary}

Extensive tensile testing has been performed on two conditions of 316ss to demonstrate the viability of this technology. Results from this baseline testing agree with published values in the literature. Miniature tensile specimens fabricated from $316 \mathrm{SS}$ have been irradiated at RTNS-II and exhibit evidence of irradiation hardening at the peak f1uence of $1.1 \times 10^{18} \mathrm{n} / \mathrm{cm}^{2}$.

\subsubsection{Progress and Status}

\subsubsection{Introduction}

Radiation damage of structural materials due to their exposure to high energy neutrons is an important consideration in the design of fusion power plants. Our current understanding of radiation damage is not sufficient to extrapolate the broad base of fission reactor irradiated data to the effects of high energy neutron irradiations upon structural materials. Therefore, data involving high energy neutron irradiations is required. Currently the only sources of high energy neutrons for materials testing have relatively small irradiation 
volumes and large flux gradients within this volume. To irradiate a statistically meaningful number of specimens in this limited volume, miniaturized specimens become necessary.

\subsubsection{Experimental Procedure}

Miniature tensile specimens have been fabricated from $0.76 \mathrm{~mm}$ diameter $20 \%$ cold worked (CW) $316 \mathrm{SS}$, heat number V87210. The chemical composition of this wire is given in Table 3.2.1. The gage sections were chemically milled using an $80 \% \mathrm{FeCl}$ plus $20 \% \mathrm{HCl}$ solution. The temperature of the solution was maintained at $38^{\circ} \mathrm{C}$. After chemically milling the gage section of a specimen to a diameter of approximately $0.28 \mathrm{~mm}$ each specimen was then electropolished.using a $10 \%$ perchloric $\left(\mathrm{HClO}_{4}\right)$ plus $90 \%$ acetic $\left(\mathrm{CH}_{3} \mathrm{COOH}\right)$ acid solution.

TABLE 3.2 .1

CHEMICAL COMPOSITION OF 316SS

(Heat No. V87210) Specimens (wt\%)

\begin{tabular}{|c|c|c|c|c|c|c|c|c|c|c|c|c|c|c|}
\hline $\mathrm{N}$ & $\mathrm{Al}$ & $\mathrm{C}$ & $\mathrm{Mn}$ & $\mathrm{P}$ & $\mathrm{S}$ & $\mathrm{Si}$ & $\mathrm{Ni}$ & $\mathrm{Cr}$ & $\mathrm{Mo}$ & $\mathrm{Nb}$ & $\mathrm{Ti}$ & $\mathrm{Cu}$ & $\mathrm{B}$ & $\mathrm{Fe}$ \\
\hline 0.006 & 0.01 & 0.05 & 1.5 & 0.01 & 0.009 & 0.5 & 13.5 & 16.6 & 2.4 & 0.03 & 0.002 & 0.08 & 0.001 & $\mathrm{BAL}$ \\
\hline
\end{tabular}

A photograph of eeveral miniature tensile specimens is shown in Figure 3.2.1 in perspective with other specimens which have been miniaturized for neutron irradiations. The reduced gage section has a minimum diameter of $U .21$ to $0.30 \mathrm{~mm}$ and a "plastir gage length" of 2.0 to $4.0 \mathrm{~mm}$. A non-contacting laser telemetrix system is used to measure the diameter of the specimen as a function of distance along the specimen's axis. The plastic gage length was then rhnsen to be the distance along the specimen's axis for which the specimen's diameter is less than a factor of 1.03 times the specimen's minimum diameter. 


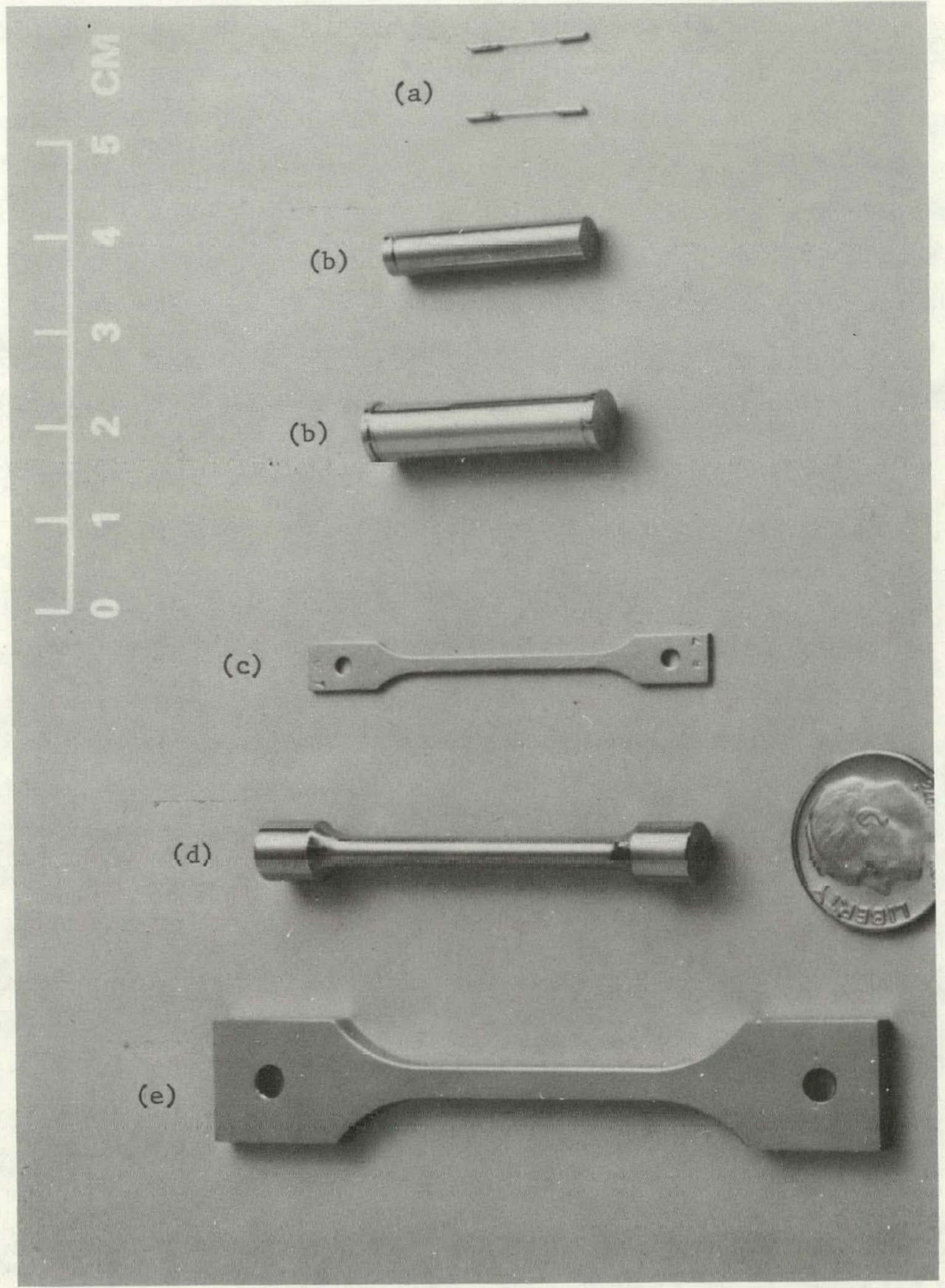

Fig. 3.2.1 (a) Miniature tensile specimens; (b) pressurized tube creep specimens;

(c) flat tensile specimens; (d) Fermi tensile specimen; and (e) flat tensile specimen. 
The factor of 1.03 was chosen as a result of an investigation of the values of yield stress and total elongation as a function of plastic gage length for each specimen. In particular, the average yield stress and total elongation values were calculated for the $20 \% \mathrm{CW}$ specimens as a function of their plastic gage length which was defined as the distance along the specimen's axis for which the specimen's diameter is less than a factor of $1.01,1.02,1.03$, and 1.04 times the specimen's minimum diameter. We found the standard deviation of the average values for yield stress and total elongation decreased as the factor defining the maximum diameter in the gage length increased. Since there was essentially no change in the average values of the yield stress as the factor was increased from 1.03 to 1.04 , the factor of 1.03 was chosen for the definition of the plastic gage length.

Micrographs of the gage sections for two conditions of 316 SS are shown in Figure 3.2.2. A transverse view of the gage section of a specimen fabricated from $20 \% \mathrm{CW} 316 \mathrm{SS}$ is shown in Figure 3.2.2(a). The cross section is approximately circular and the grain size is estimated to be ASTM 非. A longitudinal view of the gage section of a specimen made from annealed $\left(975^{\circ} \mathrm{C} / 15 \mathrm{~min} / \mathrm{AC}\right) 316 \mathrm{SS}$ is shown in Figure 3.2.2(b). The grain size for the annealed $316 \mathrm{SS}$ is also estimated to be ASTM \#7. Microhardness measurements were performed on the gage sections of miniature tensile specimens fabricated from both conditions of 316.S. The microhardness of the $20 \%$ CW specimen was found to be $230 \pm 8 \mathrm{DPH}$ $(500 \mathrm{gm})$ and the microhardness of the annealed specimen was found to be $138 \pm 3 \mathrm{DPH}(500 \mathrm{gm})$.

The tensile marhine for performing specimen testing has been described previously. ${ }^{1}$ The data was recorded on an $x-y$ chart recorder. A total of 17 specimens in the $20 \%$ CW condition and 25 specimens in the annealed condition were tested to provide baseline tensile properties data and to give an estimate of the uncertainty this miniature tensile technology has in the extraction of tensile properties for 316SS. Al1 tests were performed at room temperature. 

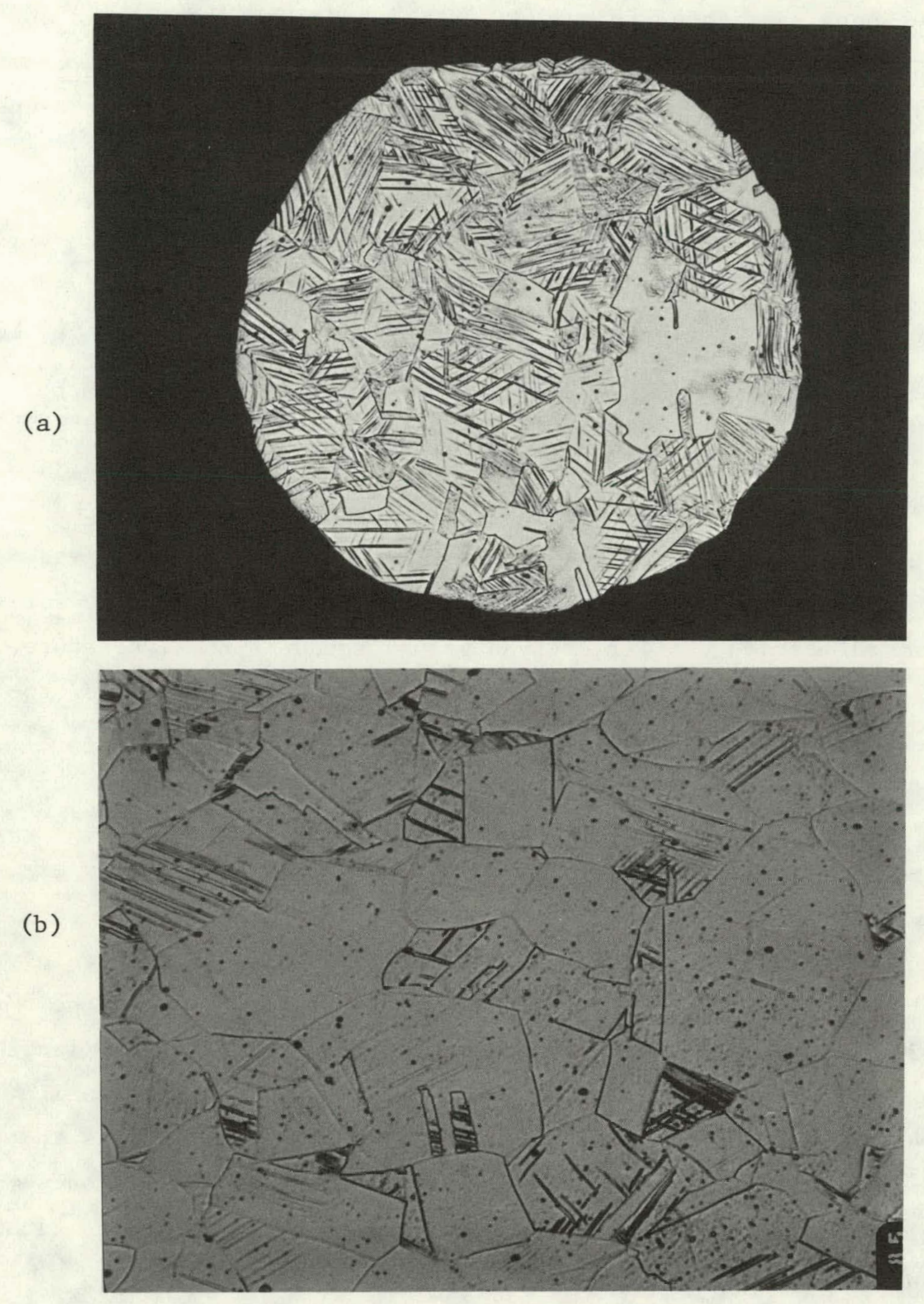

Fig. 3.2.2 Micrographs of the gage sections of miniature tensile specimens: (a) transverse section at $300 \mathrm{x}$ for $20 \% \mathrm{CW}$ 316SS specimen; and (b) longitudinal section at $400 \mathrm{x}$ for annealed $316 \mathrm{SS}$ specimen. 
Specimens fabricated from $316 \mathrm{SS}$ and $\mathrm{Ni}$ have been irradiated at the Lawrence Livermore Laboratory (LLL) Rotating Target Neutron Source RTNS-II. The details of the irradiation have been reported elsewhere. ${ }^{2}$ The miniature tensile specimens were irradiated at room temperature with $14 \mathrm{MeV}$ neutrons to a peak fluence of $1.1 \times 10^{18} \mathrm{n} / \mathrm{cm}^{2}$.

\subsubsection{Results}

The results of the baseline testing of the two conditions of 316SS are shown in Tables 3.2 .2 and 3.2.3. In particular, for the $20 \% \mathrm{CW}$ 316SS results which are shown in Table 3.2 .2 , we found that the average value for the yield stress is in good agreement with published values for these tensile properties. ${ }^{3}$ The average value for the ultimate Lensile strength from the miniature tensile specimens was lower than values found in the literature and the average value for the total elongation was larger than values found in the literature. The uncertainty in each of the average values for these tensile properties corresponds to the standard deviation in the average value. This standard deviation in the average value reflects the uncertainty which one could expect for the tensile property extracted from a single tensile test. In particular, for the tensile properties extracted in this study we have a $2 \%$ uncertainty in the $11+$ imate tensile strength, a $3 \%$ uncertainty in the yield stress and a $25 \%$ uncertainty in the total elongation. The relatively large uncertainty in the total elongation arises from the profile variation in the gage length from specimen to specimen. The uncertainty in the ultimate tensile strength and yield stress principally arises from uncertainties in the determination of the minimum crnss sertional area for a specimen.

The results from the miniature tensile testing of annealed 316SS are shown in Table 3.2.3. The measured va1ups for yield stress and ultimate tensile strength are in good agreement with published results. 4

The results from the testing of the $316 \mathrm{SS}$ specimens irradiated in RTNS-II are shown in Figures 3.2.2 and 3.2.4 and are summarized in Table 3.2.4. The values for the tensile properties for a given 
TABLE 3.2.2

TENSILE RESULTS ON UNIRRADIATED $20 \% \mathrm{CW} 316 \mathrm{SS}$

\begin{tabular}{|c|c|c|c|c|c|c|}
\hline $\begin{array}{c}\text { Specimen } \\
\text { No. }\end{array}$ & $\begin{array}{l}\text { Minimum } \\
\text { Diameter (mm) }\end{array}$ & $\begin{array}{l}\text { Plastic Gage } \\
\text { Length (mm) }\end{array}$ & $\begin{array}{l}\text { Yield Stress } \\
(\mathrm{MPa})\end{array}$ & $\begin{array}{l}\text { Ultimate Tensile } \\
\text { Strength (MPa) }\end{array}$ & Total & $\begin{array}{l}\text { Elongation } \\
(\%)\end{array}$ \\
\hline $\mathrm{S} 01$ & 0.253 & 5.25 & 656 & 701 & & 21 \\
\hline $\mathrm{s} 02$ & 0.278 & 2.86 & 639 & 712 & & 32 \\
\hline S03 & 0.226 & 2.00 & 644 & 706 & & 25 \\
\hline S04 & 0.232 & 4.15 & 656 & 725 & & 26 \\
\hline S05 & 0.197 & 2.65 & 597 & 697 & & 25 \\
\hline S06 & 0.263 & 2.17 & 604 & 711 & & 28 \\
\hline S07 & 0.253 & 2.43 & 667 & 743 & & 50 \\
\hline S08 & 0.262 & 3.49 & 630 & 699 & & 28 \\
\hline S09 & 0.279 & 3.03 & 639 & 718 & & 30 \\
\hline $\mathrm{S} 10$ & 0.267 & 2.91 & 625 & 707 & & 36 \\
\hline S11 & 0.267 & 4.20 & 612 & 703 & & 33 \\
\hline $\mathrm{S} 12$ & 0.274 & 2.32 & 637 & 722 & & 31 \\
\hline $\mathrm{S} 13$ & 0.287 & 2.33 & 621 & 710 & & 51 \\
\hline S14 & 0.267 & 3.31 & 644 & 718 & & 36 \\
\hline $\mathrm{S} 15$ & 0.263 & 4.07 & 632 & 700 & & 31 \\
\hline S16 & 0.247 & 3.21 & 615 & 714 & & 35 \\
\hline S17 & 0.246 & 2.78 & 647 & 727 & & 37 \\
\hline \multirow{2}{*}{\multicolumn{2}{|c|}{$\begin{array}{l}\text { Average and Standard Dev. } \\
\text { Literature Values }{ }^{3}\end{array}$}} & & $633 \pm 19(3 \%)$ & $713 \pm 12(2 \%)$ & & $33 \pm 8(25 \%)$ \\
\hline & & & $634 \pm 27$ & $817 \pm 28$ & & $14 \pm 3$ \\
\hline
\end{tabular}


TABLE 3.2 .3

TENSILE RESULTS ON UNIRRADIATED ANNEALED 316SS

\begin{tabular}{|c|c|c|c|c|c|c|c|}
\hline $\begin{array}{l}\text { Specimen } \\
\text { No. } \\
\end{array}$ & $\begin{array}{l}\text { Minimum } \\
\text { Diameter (mn) }\end{array}$ & $\begin{array}{l}\text { Plastic Gage } \\
\text { Length (mm) }\end{array}$ & $\begin{array}{c}\text { Yield Stress } \\
\text { (MPa) }\end{array}$ & $\begin{array}{l}\text { Ultimate } \\
\text { Strergth } \\
\end{array}$ & $\begin{array}{l}\text { Tensile } \\
(\mathrm{MPa})\end{array}$ & Total & $\begin{array}{c}\text { Elongation } \\
(\%)\end{array}$ \\
\hline SA01 & (1.229 & 4.09 & 304 & 599 & & & 53 \\
\hline $\mathrm{SAO} 2$ & 0.267. & 2.92 & $269^{\circ}$ & 590 & & & 87 \\
\hline $\mathrm{SAO} 3$ & (1. $2 \dot{4} 5$ & 2.71 & 265 & 588 & & & 75 \\
\hline SA04 & $0.2 \dot{4} 0$ & 2.31 & 321 & 596 & & & 67 \\
\hline SA0 5 & 0.206 & 4.15 & 280 & 575 & & & 43 \\
\hline SA06 & 0.249 & 4.35 & 309 & 603 & & & 60 \\
\hline SAO 7 & (1. 239 & 3.04 & 296 & 611 & & & 67 \\
\hline SA08 & 0.272 & 3.70 & 294 & 577 & & & 49 \\
\hline SAO9 & $(1.2 \dot{4} 0$ & 2.69 & 301 & 592 & & & 79 \\
\hline SA10 & 0.257 & 2.40 & 273 & 595 & & & 80 \\
\hline SAl1 & 0.267 & 3.81 & 274 & 593 & & & 55 \\
\hline $\mathrm{SA} 12$ & 0.236 & 3.75 & 273 & 587 & & & 54 \\
\hline SA13 & 0.291 & 2.45 & 273 & 591 & & & 88 \\
\hline $\mathrm{SAl} 4$ & 0.305 & 3.05 & 253 & 578 & & & 64 \\
\hline SAl5 & 0.274 & 3.35 & 257 & 591. & & & 62 \\
\hline SA16 & 0.272 & 3.0 .5 & 271 & 613 & & & 64 \\
\hline SAl 8 & 0.252 & 2.36 & 311 & 619 & & & 83 \\
\hline SA19 & $0.2 \dot{4} 9$ & 3.013 & 263 & 584 & & & 66 \\
\hline SA20 & 0.290 & 4.06 & 265 & 586 & & . & 59 \\
\hline SA21 & 0.254 & 3.02 & 267 & 603 & & & 67 \\
\hline $\mathrm{SA} 22$ & 0.215 & 2.83 & 276 & 593 & & & 63 \\
\hline SA23. & 0.255 & 3.77 & 277 & 591 & & & 54 \\
\hline SS01 & 0.277 & 3.88 & 299 & 601 & & & 67 \\
\hline $\mathrm{SSO} 2$ & 0.277 & 3.34 & 297 & 588 & & & 74 \\
\hline $\mathrm{SSO} 3$ & 0.259 & 2.76 & 324 & 613 & & & 87 \\
\hline \multirow{2}{*}{\multicolumn{2}{|c|}{$\begin{array}{l}\text { Average and Standard Dev. } \\
\text { Literature Values }{ }^{L}\end{array}$}} & \multirow{2}{*}{ - } & $284 \pm 21(7 \%)$ & \multicolumn{2}{|c|}{$594 \pm 12(2 \%)$} & . & $67 \pm 12(18 \%)$ \\
\hline & & & $262 \pm 44$ & \multicolumn{2}{|c|}{$574 \pm 44^{\circ}$} & & \\
\hline
\end{tabular}




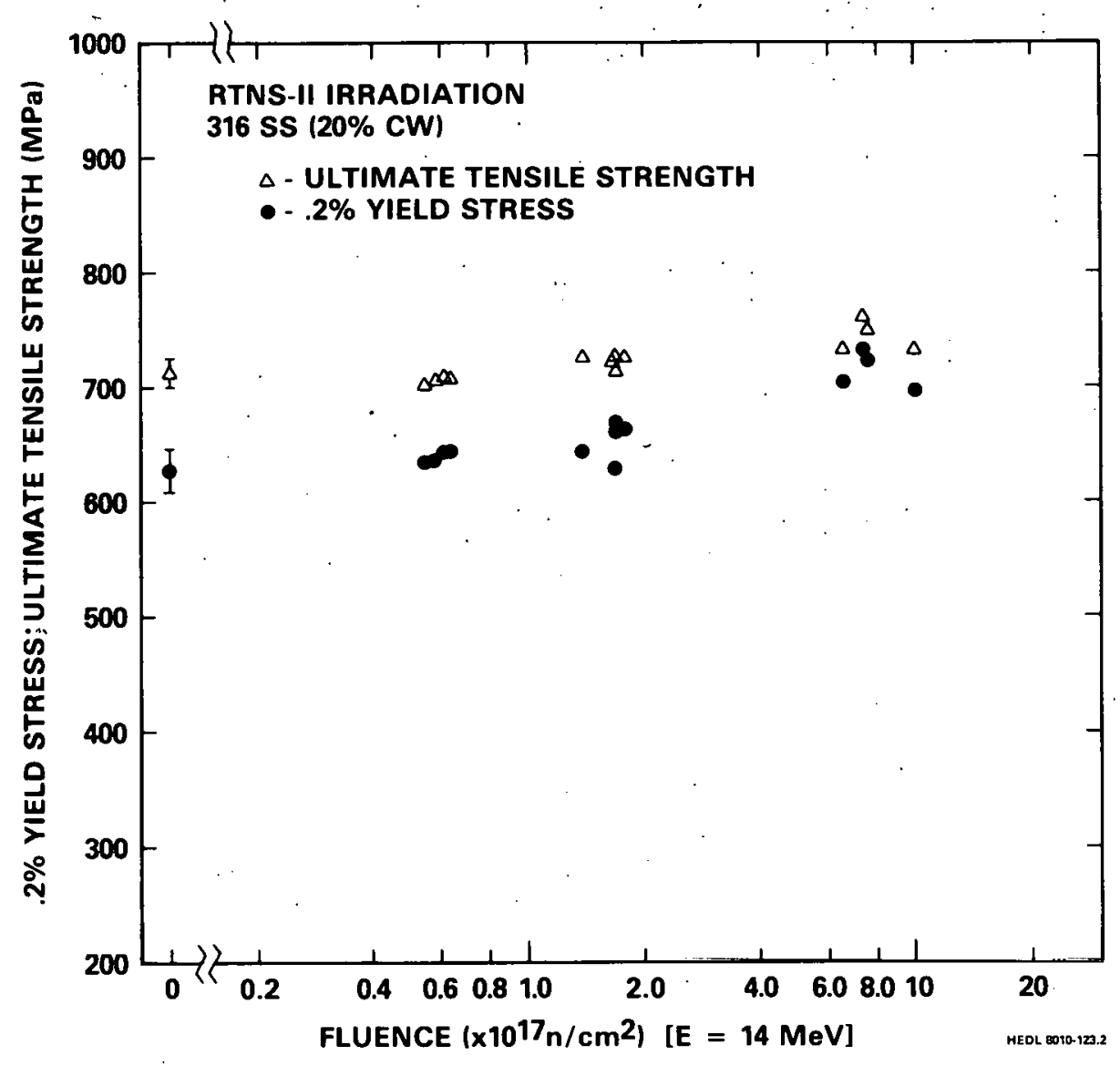

Fig. 3.2.3 Yield stress and ultimate tensile strength as a function of fluence for $20 \%$ CW 316 SS. 


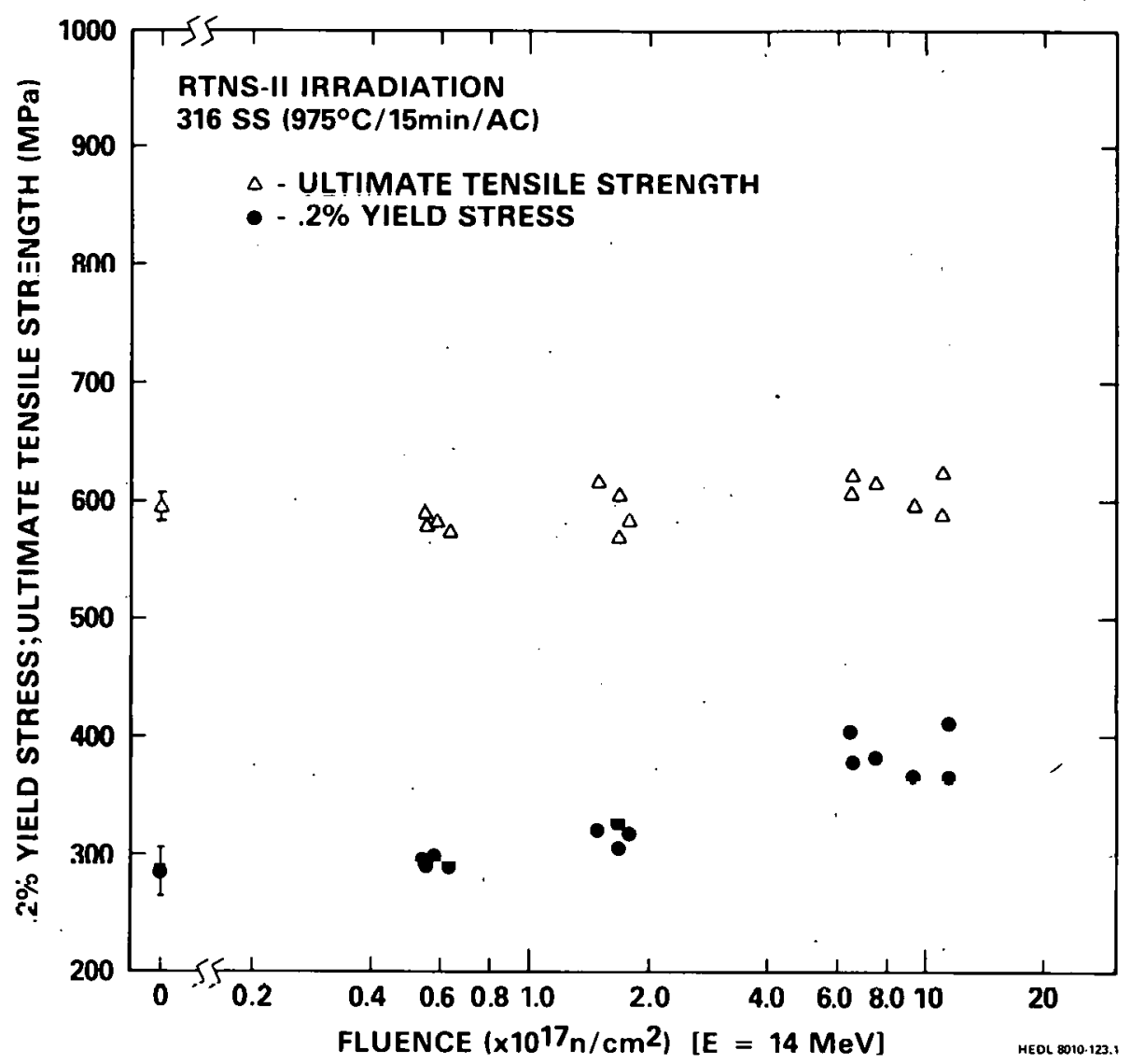

Fig. 3.2.4. Yield stress and ultillde tensile strength as a function of fluence for annealed 316ss. 
TABLE 3.2 .4

SUMMARY OF THE TENSILE PROPERTIES OF $T(d, n)$ IRRADIATED 316 SS

\begin{tabular}{|c|c|c|c|c|c|c|c|}
\hline \multirow[b]{2}{*}{$\begin{array}{c}\text { Fluence } \\
\left(\times 10^{17} \mathrm{n} ! \mathrm{cm}^{2}\right)\end{array}$} & \multicolumn{2}{|c|}{$20 \%$ Cold Work } & \multirow[b]{2}{*}{$\begin{array}{c}\text { Total El. } \\
(\%)\end{array}$} & \multicolumn{3}{|c|}{ Anneạled $\left(975^{\circ} \mathrm{C} / 15 \mathrm{~min} / \mathrm{AC}\right)$} & \multirow[b]{2}{*}{$\begin{array}{c}\text { Total EI } \\
(\%:\end{array}$} \\
\hline & $\begin{array}{c}0.2 \% \text { YS } \\
(\mathrm{MPa})\end{array}$ & $\begin{array}{c}\text { UTS } \\
\text { (MPa) }\end{array}$ & & $\begin{array}{l}\text { Fluence } \\
\left(\times 10^{17} \mathrm{n} / \mathrm{cm}^{2}\right)\end{array}$ & $\begin{array}{c}0.2 \% \text { YS } \\
(\mathrm{MPa})\end{array}$ & $\begin{array}{l}\text { UTS } \\
\text { (MPa) }\end{array}$ & \\
\hline 0 & $633 \pm 19(3 \%)$ & $713 \pm 12(2 \%)$ & $33 \pm 8(25 \%)$ & 0 & $284 \pm 21(7 \%)$ & $594 \pm 12(2 \%)$ & $67 \pm 12(18 \%)$ \\
\hline 0.55 & 635 & 700 & 32 & 0.55 & 296 & 590 & 78 \\
\hline 0.59 & 636 & 708 & 29 & 0.55 & 288 & 578 & 60 \\
\hline 0.62 & 644 & 711 & 23 & 0.59 & 299 & 580 & 63 \\
\hline 0.64 & 645 & 709. & 26 & 0.64 & 290 & 571 & 108 \\
\hline 1.4 & 644 & 727 & 30 & 1.5 & 320 & 604 & 59 \\
\hline 1.7 & 628 & 712 & 29 & 1.7 & 305 & 568 & 51 \\
\hline 1.7 & 667 & 725 & 19 & 1.7 & 324 & 604 & 50 \\
\hline 1.7 & 660 & 721 & 29 & 1.8 & 318 & 581 & 57 \\
\hline 1.8 & 663 & 724 & 28 & 6.5 & 406 & 605 & 50 \\
\hline 6.6 & 702 & 732 & 18 & 6.6 & 379. & 620 & 44 \\
\hline 7.4 & 735 & 760 & 24 & 7.5 & 382 & 614 & 58 \\
\hline 7.6 & 723 & 749 & .18 & 9.4 & 366 & 594 & 50 \\
\hline 10.2 & 696 & 731 & 17 & 11.5 & 412 & 623 & 55 \\
\hline
\end{tabular}

YS - Yield Stress: UTS = Ultimate Tensile Strength: Total El - Total Elongation. 
fluence are based upon a single tensile specimen test and the uncertainty for a specific tensile property is estimated to be equivalent to the percentage uncertainty for this property which is given for zero fluence. Figure 3.2.3 shows the effect of irradiation upon the yield stress and ultimate tensile strength for $20 \% \mathrm{CW} 316 \mathrm{SS}$. The ul- timate tensile strength increases slightly as a function of increasing neutron fluence and the yield stress increases by approximately $13 \%$ at the highest fluence. Also, at the fluence of $0.6 \times 10^{17} \mathrm{n} / \mathrm{cm}^{2}$ no change in either the yield stress or the ultimate tensile strength is observed for $20 \%$ CW 316SS. The changes in the yield stress and ultimate tensile strength as a function of fluence for the annealed $316 \mathrm{SS}$ are shown in Figure 3.2.4. The ultimate tensile strength tends to increase slightly as a function of increasing fluence and the yield stress increases by approximately $37 \%$ at the highest fluence. Again, at the fluence of $0.6 \times 10^{17} \mathrm{n} / \mathrm{cm}^{2}$ no change in these tensile properties is observed.

The results of measurements of the total elongation of these specimens are given in Table 3.2.4. The percentage uncertainty in these measurements is estimated to be $25 \%$ for the cold worked and $18 \%$ for the annealed material. Because of these large uncertainties we can only say that the total elongation shows a general decrease in its value as a function of increasing fluence for the two conditions of 31633 examined.

Jones, et $a 1^{5}$ have investigated the tensile properties of annealed 316 SS irradiated with neutrons from the $B e(d, n)$ reaction. They observe no changes in the ultimate tensile strength up to the peak fluence of $1 \times 10^{18} \mathrm{n} / \mathrm{cm}^{2}$. However, the yield stress increased by $16 \%$ and the total elongation decreased by $26 \%$. Our results are qualitatively consistent with theirs; however, we observe a significantly larger increase of $37 \%$ in the yield stress.

\subsubsection{Conclusions and Future Work}

A fabrication technique has been developed for miniature tensile specimens and a tensile machine capable of testing these specimens has built. The miniature tensile specimen's geometry represents a significant 
reduction in the size of the tensile specimen currently being used in irradiation experiments. A comparison of baseline testing results from using these miniature tensile specimens with published tensile properties data indicates that this technology may be employed to provide tensile property data on 316SS. In particular the uncertainties in our results for the yield stress and ultimate tensile strength are much less than either the microhardness or disc bend techniques which are currently being employed to obtain tensile properties data on $14 \mathrm{MeV}$ neutron irradiated materials.

The small specimen size has allowed for the irradiation of a statistically meaningful number of specimens in RTNS-II. In testing the miniature tensile specimens irradiated at RTNS-II, evidence for the irradiation hardening of the two conditions of $316 \mathrm{SS}$ was found at fluences of $1 \times 10^{18} \mathrm{n} / \mathrm{cm}^{2}$. No change in the tensile properties was found for the lowest fluence, $0.6 \times 10^{17} \mathrm{n} / \mathrm{cm}^{2}$, examined.

The fabrication technique for miniature tensile specimens has been extended to the fabrication of Ni, Ti alloy, and HT-9 specimens and baseline testing of these specimens is continuing. Reduction in area measurements are now being made on both the unirradiated and irradiated specimens. Microhardness testing is being performed to provide a correlation of hardness and the tensile data. Also, specimens have been fabricated from MFE heat 316 and HT-9, and these specimens are currently being irradiated at RTNS-II as part of the HEDL-5 experiment. 6

\section{2 .6 References}

1. E. K. Opperman, "Miniature Tensile Testing", ADIP Quarterly Progress Report, September 30, 1979, DOE/ET-0058/7, pp. 66-78.

2. R. J. Puigh and N. F. Panayotou, Tensile Properties Data on 316SS Irradiated at RTNS-II, DAFS Quarterly Progress Report, July - September, 1980, DOE/ER-0046/3, U. S. Department of Energy, in press.

3. Hanford Engineering Development Laboratory, Nuclear Systems Materials Handbook, Vol. 1, Revision 6, (June 1, 1978).

4. G. V. Smith, "An Evaluation of the Yield, Tensile, Creep and 
Rupture Strengths of Wrought $304,316,321$, and 347 Stainless Steels at Elevated Temperatures", ASTM Data Series DS 5S2, American Society for Testing and Materials, Philadelphis, PA (1969).

5. R. H. Jones, D. L. Styris, E. R. Bradley, L. R. Greenwood, and R. R. Heinrich, 'Microstructure and Tensile Properties of $T(d, n)$ and $\mathrm{Be}(\mathrm{d}, \mathrm{n})$ Neutron Irradiated Nickel, Niobrium and 316SS", Proceedings of the First Topical Meeting on Fusion Reactor Materials, Miami Beach, FL, January 29-31, 1979.

6. N. F. Panyotou, "RTNS-II Irradiation Program", DAFS Quarterly Progress Report, January - March, 1980, DOE/ER-0046/1, U. S. Department of Energy. 
3.3 THE EFFECT OF ANNEALING TEMPERATURE ON THE GRAIN SIZE OF THE PATH A PRIME CANDIDATE ALLOY - T. K. Roche and P. J. Maziasz (ORNL)

\subsubsection{ADIP Tasks}

ADIP Task I.A.5, Perform Fabrication Analysis.

\subsubsection{Objective}

The objective of this work is to vary the grain size of the Prime Candidate Alloy (PCA) over a wide range, independent of the variable MC precipitate particle distribution and dislocation microstructure developed during subsequent thermal-mechanical treatment.

\subsubsection{Summary}

Preserving homogeneity in the PCA alloy during fabrication demands solution treatment in the range 1150 to $1175^{\circ} \mathrm{C}$. These temperatures result in grain sizes ranging from ASTM 1 to 4 . Often, however, a finer grain size is required. Therefore, this study sought to decouple the final in-process anneal from the thernal-mechanical treatments to develop MC precipitate microstructures. Rapid to relatively slow heating rates and cold-work levels of 30 to $50 \%$ were used to recrystallize the material without precipitating appreciable MC or losing the homogeneity. The grain size was then simply a function of the annealing temperature. A grain size control anneal of $1100^{\circ} \mathrm{C}$ was seler.ted to produce an intermediate grain size of ASTM 4 to 7 . This allows the program to separate grain size and preirradiation microstructure effects on properties.

\subsubsection{Progress and Status}

All thermal-mechanical treatments studied to date for producing desired microstructures in the PCA use an in-process solution annealing temperature of $1175^{\circ} \mathrm{C}$. This results in grain sizes ranging from ASTM 1 to 4. During the past quarter we studied the effect of annealing temperature on the recrystallized grain size of the cold-worked alloy. This study is expected to identify a final in-process annealing temperature 
that will result in finer grain material, yet permit the generation of the various microstructures. The desired dislocation substructure and titanium-rich MC precipitate particle distribution are produced by various cold working and/or aging treatments after the final in-process anneal.

Sheet samples were annealed at $1150^{\circ} \mathrm{C}$, resulting in grain sizes ranging from ASTM 2 to 4, then cold rolled 30 and 50\% to final thicknesses of 0.7 and $0.5 \mathrm{~mm}(0.028$ and $0.020 \mathrm{in.})$, respectively. The specimens were then recrystallized in argon at $25^{\circ} \mathrm{C}$ temperature intervals in the range 1050 through $1175^{\circ} \mathrm{C}$. Anneal times were 15 and 30 min. The recrystallization heat treatments were carried out in two furnaces providing variable heating rates, particularly through the temporature range 500 to $900^{\circ} \mathrm{C}$, where carbide precipitation can be fairly rapid. Two heating rates were used in furnace $A$ : one rate was slow (Fig. 3.3.1) from room temperature to the annealing temperature, and the second rate (Fig. 3.3.2) was rapid between 500 and $900^{\circ} \mathrm{C}$. The one heating rate used in furnace $B$ (Fig. 3.3.3) was rapid from room temperature to the annealing temperature.

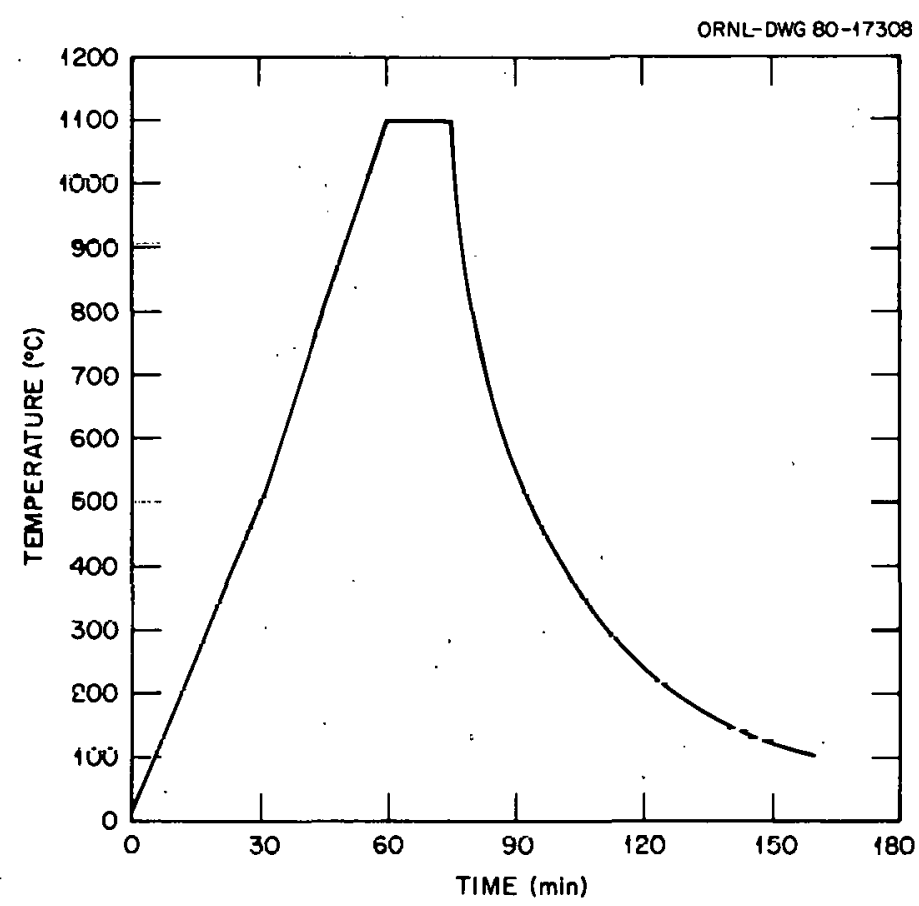

Fig. 3.3.1. Typical Heating-Cooling Cycle for Recrystallization of the Prime Candidate Alloy in Furnace A. Slow heatup from room temperature to annealing temperature. 


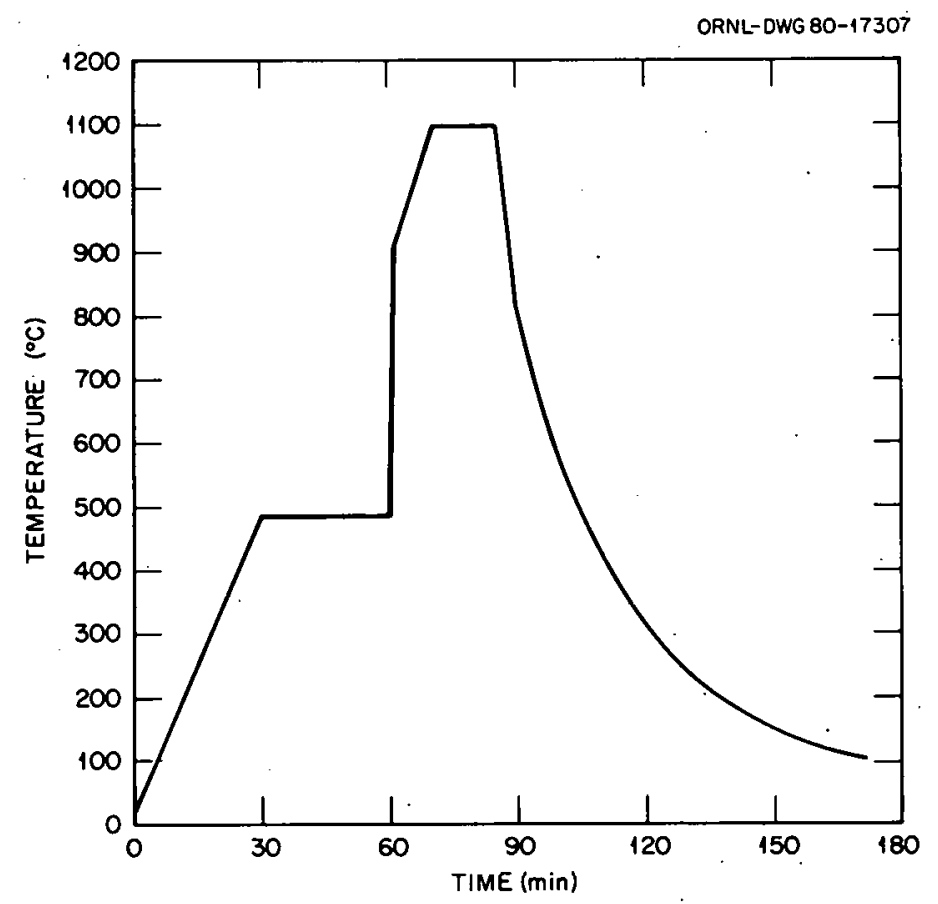

Fig. 3.3.2. Typical Heating-Cooling Cycle for Recrystallization of Prime Candidate Alloy in Furnace A. Fast heatup between 500 and $900^{\circ} \mathrm{C}$.

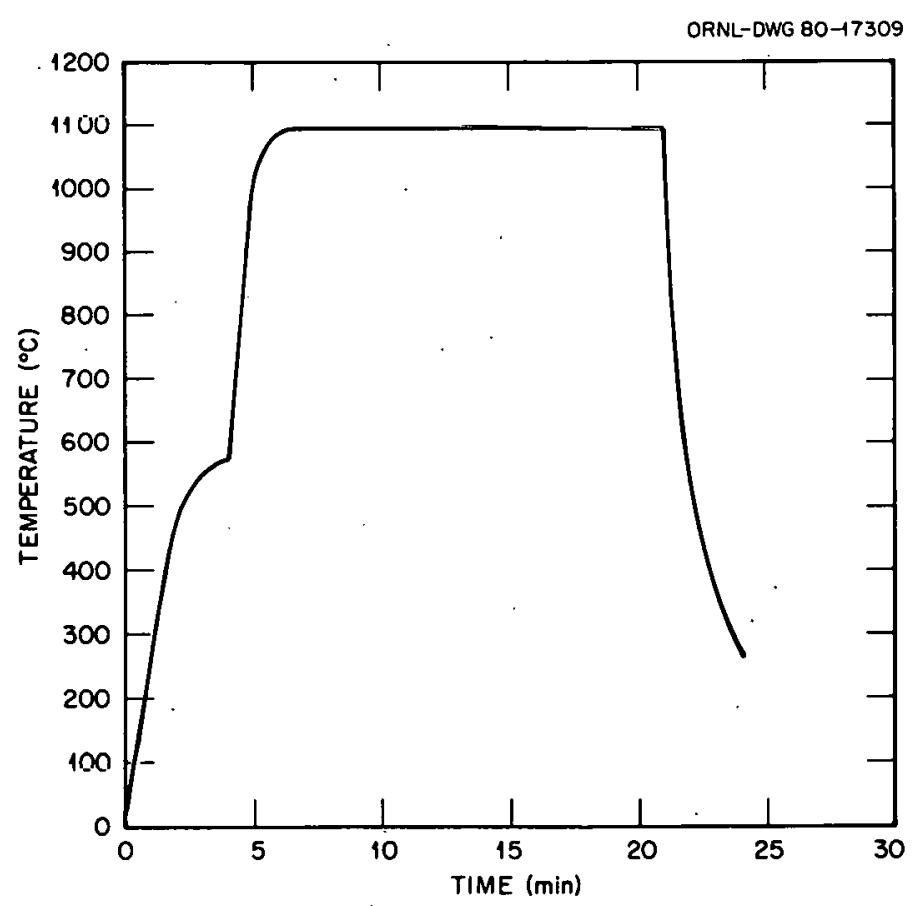

Fig. 3.3.3. Typical Heating-Cooling Cycle for Recrystallization of Prime Candidate Alloy in Furnace B. Fast heatup from room temperature to aluteding tempcrature. 
The results of grain size measurements on the recrystallized samples for the three heating rates are presented in Tables 3.3.1, 3.3.2, and 3.3.3. Within the limits of the experimental conditions, there is good agreement: in the grain size, which can be expected for these annealing temperatures. In addition, for the three heating rates used, the degree of carbide precipitation visible by optical metallography does not differ appreciably. Microstructures of the recrystallized alloy (Fig. 3.3.4) are considered typical.

These results lead to the specification of a $1100^{\circ} \mathrm{C}$ recrystallization treatment as the final in-process anneal for developing a finer grain size in the PCA. The grain size can be varied independent of the thermalmechanical treatments used to produce variable MC microstructures. Fabrlcarion of sperimen stock incorporatilig luls change is under way for future radiation effects evaluation.

Table 3.3.1. Grain Size of Path A Prime Candidate Alloy Recrystallized in the Temperature Range 1050 to $1175^{\circ} \mathrm{C}$ after a Slow Heating Rate $^{\alpha}$ in Furnace A

\begin{tabular}{cll}
\hline \multirow{2}{*}{$\begin{array}{c}\text { Tèmperature } \\
\left({ }^{\circ} \mathrm{C}\right)\end{array}$} & \multicolumn{2}{c}{ Kecrystallized Grain Size (ASTM) } \\
\cline { 2 - 3 } & $30 \%$ Cold Worke.d & $50 \%$ Cold Worked \\
\hline 1050 & No test & No test \\
1075 & $7-8$ & 8 \\
1100 & $4-6$ & $5-7$ \\
1125 & No test & No test \\
1150 & $3-4$ & $3-4$ \\
1175 & No test & No test \\
\hline
\end{tabular}

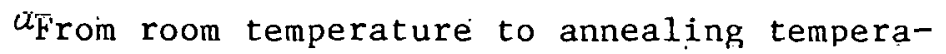
Lure (oce rig. J.j.1).

$b_{\text {Annealed }} 15 \mathrm{~min}$ at temperature. 
Table 3.3.2. Grain Size of Path A Prime Candidate

Alloy Recrystallized in the Temperature Range 1050 to $1175^{\circ} \mathrm{C}$ after a Rapid Heating Rate $^{\alpha}$ in Furnace A

\begin{tabular}{cll}
\hline \multirow{2}{*}{$\begin{array}{c}\text { Temperature } \\
\left({ }^{\circ} \mathrm{C}\right)\end{array}$} & \multicolumn{2}{c}{ Recrystallized Grain Size (ASTM) } \\
\cline { 2 - 3 } & $30 \%$ Cold Worked $b$ & $50 \%$ Cold Worked $b$ \\
\hline 1050 & No test & No test \\
1075 & $7-8$ & $7-8$ \\
1100 & $5-7$ & $5-7$ \\
1125 & No test & No test \\
1170 & $2-4$ & $2-4$ \\
\hline
\end{tabular}

$\alpha_{\text {Between }} 500$ and $900^{\circ} \mathrm{C}$ (see Fig. 3.3.2).

$b_{\text {Annealed }} 15 \mathrm{~min}$ at temperature.

Table 3.3.3. Grain Size of Path A Prime Candidate Alloy Recrystallized in the Temperature Range 1050 to $1175^{\circ} \mathrm{C}$ after a Rapid Heating Rate $^{a}$ in Furnace $B$

\begin{tabular}{|c|c|c|c|c|}
\hline \multirow{3}{*}{$\begin{array}{c}\text { Temperature } \\
\left({ }^{\circ} \mathrm{C}\right)\end{array}$} & \multicolumn{4}{|c|}{ Recrystallized Grain Size (ASTM) } \\
\hline & $30 \% \operatorname{Cold}$ & Worked & $50 \%$ Cold & Worked \\
\hline & $15 \min b$ & $30 \min ^{b}$ & $15 \min ^{b}$ & $30 \min b$ \\
\hline 1050 & No test & No test & 8 & 8 \\
\hline 1075 & $7-8$ & $7-8$ & 7 & 7 \\
\hline 1100 & $5-7$ & $5-7$ & $5-6$ & $4-5$ \\
\hline 1125 & No test & No test & $3-4$ & 3 \\
\hline 1150 & No test & No test & $3-4$ & $2-4$ \\
\hline 1175 & No test & No test & $1-4$ & $1-4$ \\
\hline
\end{tabular}

$a_{\text {From room temperature to annealing tempera- }}$

ture (see Fig. 3.3.3).

$b_{\text {Annealing times at temperature. }}$ 

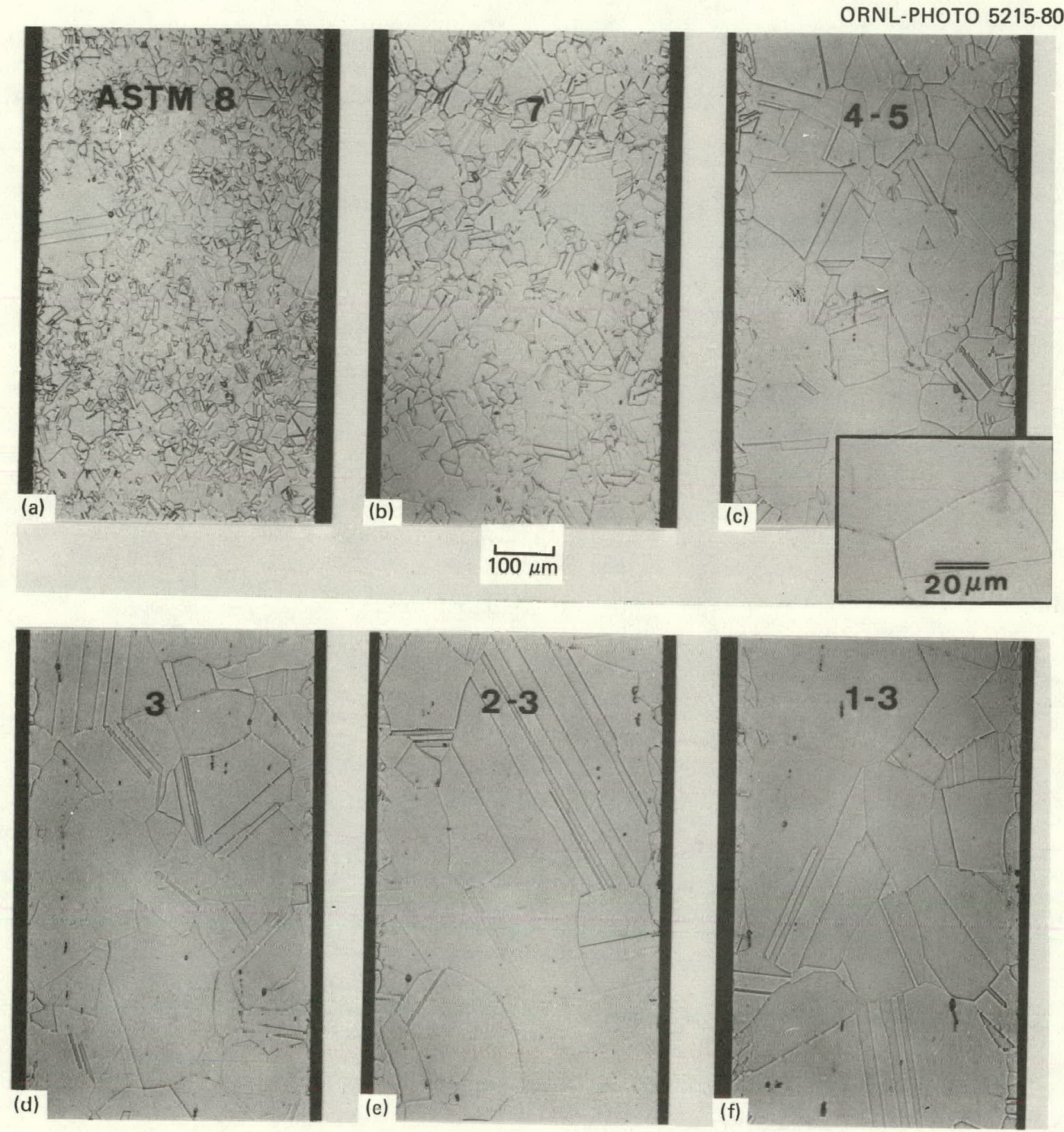

Fig. 3.3.4. Typical Microstructures of Prime Candidate Alloy Cold Worked $50 \%$ and Recrystallized for $30 \mathrm{~min}$ Within the Temperature Range 1050 to $1175^{\circ} \mathrm{C}$. 
4. PATH B ALlOY DEVELOPMENT - higher STRENGTH Fe-Ni-Cr ALLOYS 
Blank

80 
5. PATH C ALLOY DEVELOPMENT - REACTIVE AND REFRACTORY ALLOYS 
5.1 TENSILE PROPERTIES AND MICROSTRUCTURE OF HELIUM-INJECTED AND

REACTOR-IRRADIATED V-20\% Ti - M. P. Tanaka, * E. E. Bloom, and J. A. Horak (OKNL)

\subsubsection{ADIP Task}

ADIP Tasks I.B.15, Tensile Properties of Reactive and Refractory Alloys, and I.C.4, Microstructures and Swelling in Reactive and Refractory Alloys.

\section{1 .2 Objective}

The objective of this work was to determine the effect of injected helium followed by neutron irradiation on the mechanical properties and microstructures of $\mathrm{V}-20 \% \mathrm{Ti}$. These results will be used to determine the potential use of $\mathrm{V}-20 \% \mathrm{Ti}$ in fusion reactor service.

\section{1 .3 Summary}

Sheet tensile samples of $\mathrm{V}-20 \% \mathrm{Ti}$ preinjected with 90 and 200 at. ppm He have been irradiated to about $20 \mathrm{dpa}$ in the Experimental Breeder Reactor (EBR-II) in the range 400 to $700^{\circ} \mathrm{C}$. Mechanical properties and microstructure of the irradiated specimen have been compared with those of control specimens. Helium embrittlement of $\mathrm{V}-20 \% \mathrm{~T} i$ becomes appreciable above test temperatures of $575^{\circ} \mathrm{C}$. Neutron irradiation enhaneed the cmbrittlement of the helium-injected $\mathfrak{V} 20 \% \mathrm{Ti}$. Ilelium injection also assisted cavity formation in the reactor-irradiated $\mathrm{V}-20 \% \mathrm{Ti}$. The size and concentration of cavities depended on the amount of injected helium.

\section{1 .4 Progress and Status}

The details of helium injection, neutron irradiation, and postirradiation testing were reported previously,1,2 Sheet specimens of $\mathrm{V}-20 \% \mathrm{Ti}$ (chemical composition $19.7 \% \mathrm{Ti}, 130$ wt ppm C, 830 wt ppm 0, and 830 wt ppm $\mathrm{N}$, annealed $0.5 \mathrm{~h}$ in vacuum at $900^{\circ} \mathrm{C}$ ) were injected to 90 and 200 at. ppm He. The helium-injected tensile specimens were irradiated in

\footnotetext{
*On leave from Japanese Atomic Energy Research Institute (JAERI) for one-year assignment to ORNL.
} 
row 7 of EBR-II to a neutron fluence of about $3 \times 10^{26}$ neutrons $/ \mathrm{m}^{2}$ [>0.1 $\mathrm{MeV}(0.016 \mathrm{pJ})]$, corresponding to about $20 \mathrm{dpa}$. Irradiation temperatures were about $400,575,625$, and $700^{\circ} \mathrm{C}$ for samples contained in either static sodium or helium. After neutron irradiation the microstructures were characterized by transmission electron microscopy, tensile tests were conducted at the respective irradiation temperatures, and fracture surfaces were examined by scanning-electron microscopy.

Tensile results on control, helium-injected, and neutron-irradiated specimens are tabulated in Table 5.1.1. The data are also shown graphically in the first nine figures of this report.

Stress-strain curves for the specimens preinjected with 0,90 , and 200 at. ppm He and tested at 400 and $700^{\circ} \mathrm{C}$ are plotted in Figs. 5.1 .1 and 5.1.2. The yield stress, ultimate stress, and total elongation of the specimens before neutron irradiation are shown as a function of test temperature in Figs. 5.1.3 through 5.1.5. The injected helium has increased the yield stress, the ultimate stress, and the total elongation of the alloy for test temperatures of $525^{\circ} \mathrm{C}$ and lower. The increases in strength and elongation depended on the amount of injected helium. Above $575^{\circ} \mathrm{C}$ the injected helium did not greatly affect strength but did affect elongation. The reduction of the total elongation depended on the amounts of preinjected helium. The higher the test temperature, the larger was the reduction of elongation. Elongation at $700^{\circ} \mathrm{C}$ was 13.3 and $8.7 \%$, respectively, in the material injected with 90 and 200 at. ppm He. These values are 69 and $45 \%$ of the elongation of the helium-free material, as shown in Fig. 5.1.5. The fracture surfaces of specimens preinjected with 0,90 , and 200 at. ppm He and tested at $700^{\circ} \mathrm{C}$ are shown in Fig. 5.1.6. With no injected helium the failure mode was clearly ductile, and grain boundary failure was not evident. With injected helium the failures became mixed ductile and grain boundary separation modes. Grain boundary facets are visible on the fracture surface and grain boundary cracks on the specimen surface. The fraction of the grain boundary fracture increased as the helium content increased from 90 to 200 at. ppm He. 
Table 5.1.1. Helium Contents, Irradiation Conditions, and Tensile Properties of $\mathfrak{K} 20 \% \mathrm{Ti}$

\begin{tabular}{|c|c|c|c|c|c|c|c|c|}
\hline \multirow{3}{*}{$\begin{array}{c}\text { Pre- } \\
\text { 1njected } \\
\text { Heliuma } \\
(\text { at.. ppm) }\end{array}$} & \multicolumn{3}{|c|}{ Irradiation Conditions $b$} & \multirow{3}{*}{$\begin{array}{l}\text { Test } \\
\text { Temper- } \\
\text { ature } \\
\left({ }^{\circ} \mathrm{C}\right)\end{array}$} & \multicolumn{4}{|c|}{ Tensile Properties $e$} \\
\hline & \multirow{2}{*}{$\begin{array}{l}\text { Temper- } \\
\text { ature }{ }^{c} \\
\left({ }^{\circ} \mathrm{C}\right)\end{array}$} & \multirow{2}{*}{$\begin{array}{l}\text { Fluenced } \\
(>0.1 \mathrm{MeV}) \\
\left.\text { (neutrons } / \mathrm{m}^{2}\right)\end{array}$} & \multirow{2}{*}{$\begin{array}{l}\text { Environ- } \\
\text { ment }\end{array}$} & & \multicolumn{2}{|c|}{ Strength, MPa } & \multicolumn{2}{|c|}{ Elongation, $\%$} \\
\hline & & & & & $\begin{array}{l}0.2 \% \\
\text { Yield }\end{array}$ & Ultimate & Uniform & Total \\
\hline $\begin{array}{l}0 \\
0 \\
0 \\
0 \\
0 \\
0\end{array}$ & & & & $\begin{array}{r}25 \\
400 \\
525 \\
575 \\
625 \\
700\end{array}$ & $\begin{array}{l}546 \\
387 \\
400 \\
407 \\
384 \\
345\end{array}$ & $\begin{array}{l}661 \\
588 \\
668 \\
681 \\
619 \\
49 y\end{array}$ & $\begin{array}{l}12.0 \\
11.4 \\
13.0 \\
14.1 \\
12.3 \\
13.4\end{array}$ & $\begin{array}{l}19.6 \\
13.3 \\
14.7 \\
19.0 \\
19.9 \\
19.2\end{array}$ \\
\hline $\begin{array}{l}90 \\
90 \\
90 \\
90 \\
90\end{array}$ & . & & . & $\begin{array}{l}400 \\
325 \\
575 \\
625 \\
700\end{array}$ & $\begin{array}{l}477 \\
443 \\
405 \\
387 \\
330\end{array}$ & $\begin{array}{l}647 \\
701 \\
658 \\
597 \\
531\end{array}$ & $\begin{array}{l}11.3 \\
16.6 \\
13.0 \\
10.3 \\
10.9\end{array}$ & $\begin{array}{l}14.0 \\
1.8 .2 \\
21.5 \\
18.1 \\
13.3\end{array}$ \\
\hline $\begin{array}{l}200 \\
200 \\
200 \\
200 \\
200\end{array}$ & & $\cdot$ & & $\begin{array}{l}400 \\
525 \\
575 \\
625 \\
700\end{array}$ & $\begin{array}{l}515 \\
468 \\
433 \\
410 \\
362\end{array}$ & $\begin{array}{l}649 \\
708 \\
653 \\
644 \\
455\end{array}$ & $\begin{array}{r}12.8 \\
16.7 \\
15.1 \\
14.1 \\
8.3\end{array}$ & $\begin{array}{r}15.1 \\
18.2 \\
17.3 \\
15.6 \\
8.7\end{array}$ \\
\hline $\begin{array}{l}0 \\
0 \\
0\end{array}$ & $\begin{array}{l}575 \\
625 \\
700\end{array}$ & $\begin{array}{l}2-4 \times 10^{26} \\
2-4 \\
2-4\end{array}$ & $\begin{array}{l}\mathrm{Na} \\
\mathrm{Na} \\
\mathrm{Na}\end{array}$ & $\begin{array}{l}575 \\
625 \\
700\end{array}$ & $\begin{array}{l}376 \\
361 \\
399\end{array}$ & $\begin{array}{l}603 \\
475 \\
453\end{array}$ & $\begin{array}{r}10.6 \\
1.8 \\
3.0\end{array}$ & $\begin{array}{r}13.3 \\
3.1 \\
4.9\end{array}$ \\
\hline $\begin{array}{l}90 \\
90\end{array}$ & $\begin{array}{l}400 \\
575\end{array}$ & $\begin{array}{l}2-4 \\
2-4\end{array}$ & $\begin{array}{l}\text { Na } \\
\text { l. }\end{array}$ & $\begin{array}{l}400 \\
575\end{array}$ & $\begin{array}{l}629 \\
389\end{array}$ & $\begin{array}{l}777 \\
581\end{array}$ & $\begin{array}{r}4.9 \\
12.5\end{array}$ & $\begin{array}{r}7.0 \\
15.6\end{array}$ \\
\hline $\begin{array}{l}2000 \\
200 \\
200\end{array}$ & $\begin{array}{l}400 \\
575 \\
625\end{array}$ & $\begin{array}{l}2-4 \\
2-4 \\
2-4\end{array}$ & $\begin{array}{l}\mathrm{Na} \\
\mathrm{Na} \\
\mathrm{Na}\end{array}$ & $\begin{array}{l}100 \\
575 \\
625\end{array}$ & $\begin{array}{l}656 \\
382 \\
386\end{array}$ & $\begin{array}{l}814 \\
567 \\
575\end{array}$ & $\begin{array}{r}6.7 \\
12.7 \\
4.9\end{array}$ & $\begin{array}{r}8.2 \\
14.0 \\
5 . ?\end{array}$ \\
\hline $\begin{array}{l}0 \\
0 \\
0\end{array}$ & $\begin{array}{l}400 \\
700 \\
700\end{array}$ & $\begin{array}{l}2-4 \\
2-4 \\
2-4\end{array}$ & $\begin{array}{l}\mathrm{He} \\
\mathrm{He} \\
\mathrm{He}\end{array}$ & $\begin{array}{l}400 \\
400 \\
700\end{array}$ & $\begin{array}{l}677 \\
439 \\
385\end{array}$ & $\begin{array}{l}812 \\
606 \\
468\end{array}$ & $\begin{array}{r}4.8 \\
11.3 \\
14.1\end{array}$ & $\begin{array}{r}6.6 \\
13.3 \\
20.4\end{array}$ \\
\hline 90 & 700 & $2-4$ & $\mathrm{He}$ & 700 & 354. & 424 & 4.9 & 6.0 \\
\hline 200 & 7000 & $2=4$ & Ho & 700 & .354 & 499 & 2.9 & 3.2 \\
\hline $\begin{array}{l}u_{\text {Nomi }} \\
b_{\text {Blan }} \\
c_{\text {Desi }} \\
d_{\text {Esti }} \\
\text { estra }\end{array}$ & $\begin{array}{l}1 \text { value. } \\
\text { spares i } \\
\text { tempera } \\
\text { ted valu } \\
\text { race is }\end{array}$ & $\begin{array}{l}\text { icate control } \\
\text { re. lieasureme } \\
\text { Measurement } \\
.67 \times 10^{-4 / 3}\end{array}$ & $\begin{array}{l}\text { erimen. } \\
\text { on tempe } \\
\text { fluetice } \\
\left.U_{t} / \min \right) \text {. }\end{array}$ & $\begin{array}{l}\text { are mo } \\
\text { aitor }\end{array}$ & or is & $\begin{array}{l}\text { lanned. } \\
\text { ess. }\end{array}$ & & \\
\hline
\end{tabular}




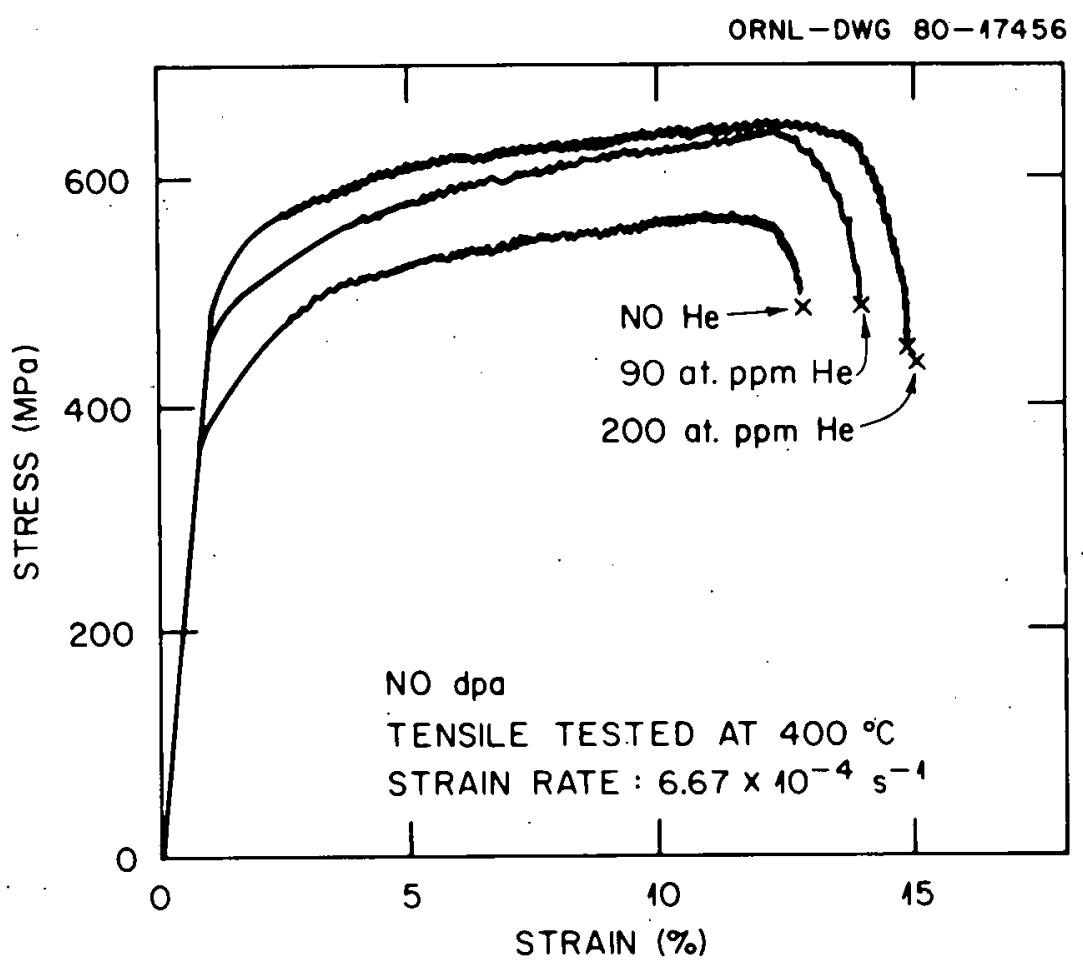

Fig. 5.1.1. Effect of Injected Helium on the Stress-Strain Behavior of Annealed, Unirradiated $\mathrm{V}-20 \% \mathrm{Ti}$ at a Test Temperature of $400^{\circ} \mathrm{C}$.

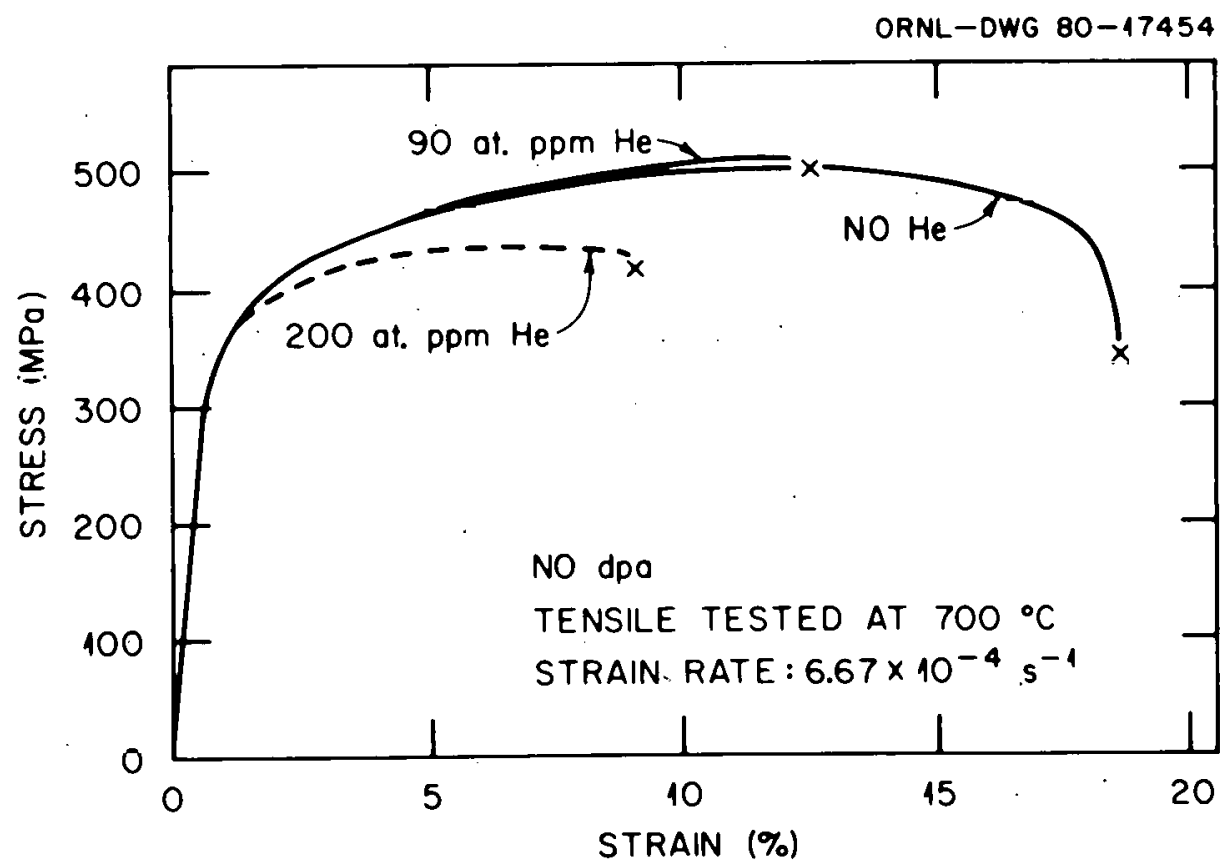

Fig. 5.1.2. Effect of Injected Helium on the Stress-Strain Behavior of Annealed, Unirradiated $\mathrm{V}-20 \% \mathrm{Ti}$ at a Test Temperature of $700^{\circ} \mathrm{C}$. 


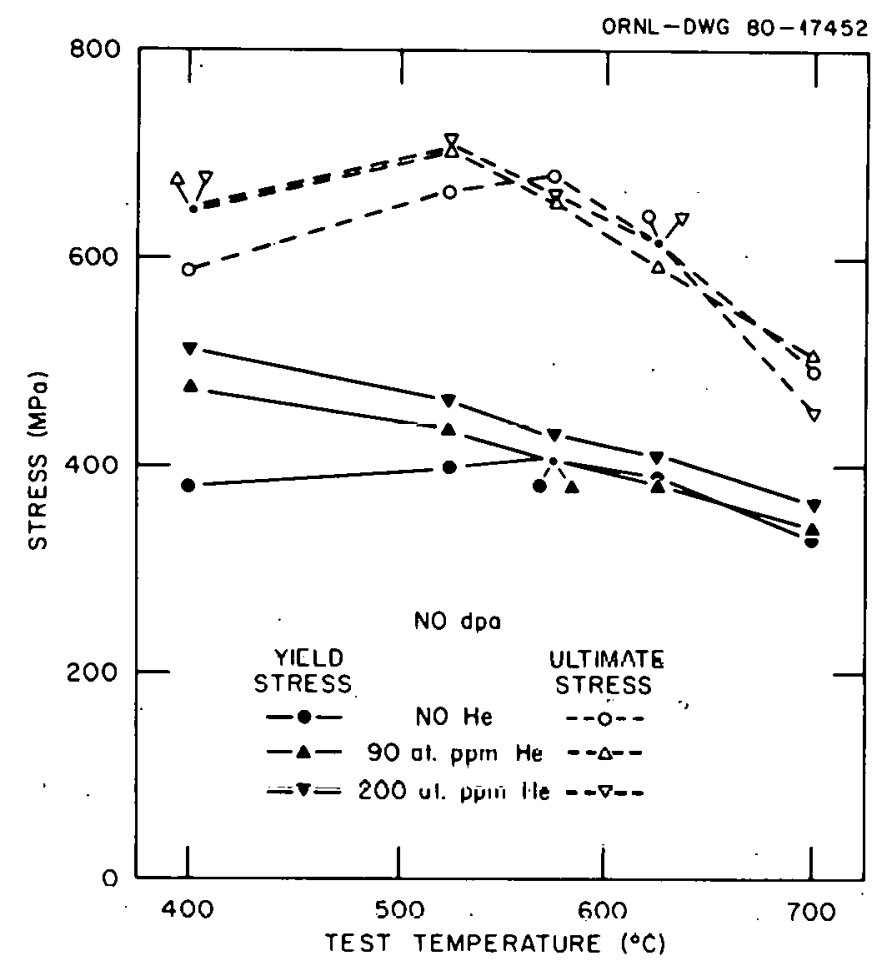

Fig. 5.1:3. Effect of Injected Helium on the Yield and Ultimate Stress of Unirradiated $\mathrm{V}-20 \% \mathrm{~T} i$ as a Function of Temperature.

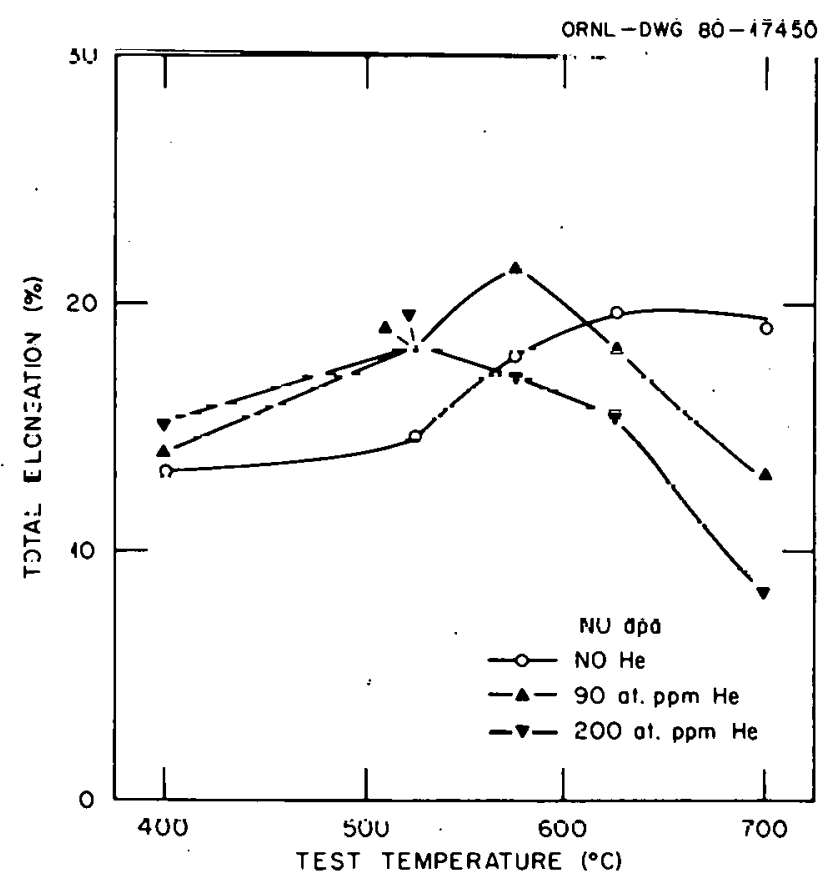

Fig. 5.1.4. Effect of Injected Helium on the Total Elongation of Unirradiated $\mathrm{V}-20 \% \mathrm{Ti}$ as a Function of Temperature. 


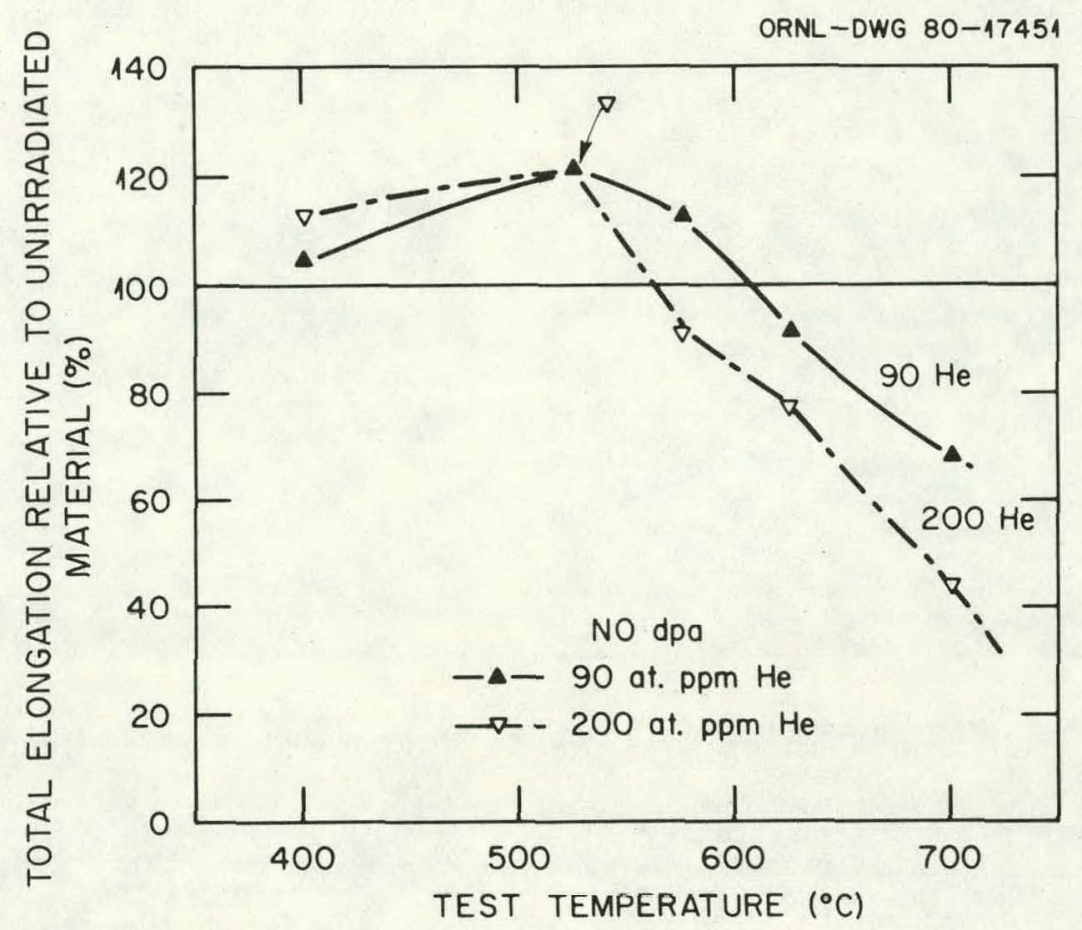

Fig. 5.1.5. Percentage Change in the Total Elongation of $\mathrm{V}-20 \% \mathrm{Ti}$ Produced by Two Levels of Injected Helium as a Function of Test Temperature.

Stress-strain curves of neutron-irradiated material preinjected with 0 , 90, and 200 at. ppm He and tested at 400 and $700^{\circ} \mathrm{C}$ are plotted, respectively, in Figs. 5.1.7 and 5.1.8. The yield stress, ultimate stress, and total elongation of the neutron-irradiated specimens are shown as a function of test temperature in Figs. 5.1.9 and 5.1.10. The test temperatures were near the neutron irradiation temperature. Neutron irradiation at $400^{\circ} \mathrm{C}$ has increased the yield stress and ultimate stress of the specimen, especially for the one containing no injected helium (compare Figs. 5.1.3 and 5.1.9). On the other hand, neutron irradiation above $575^{\circ} \mathrm{C}$ did not significantly affect the yield or ultimate stress. The level of preinjected helium did not appreciably affect the material strength following neutron irradiation. The total elongation of the irradiated material was lower at all test temperatures (except the helium free material at $700^{\circ} \mathrm{C}$ ). With no preinjected helium the elongation increased as the irradiation and test temperature increased. At $700^{\circ} \mathrm{C}$ neutron irradiation seemingly did not affect the elongation of helium free material (compare Figs. 5.1.4 and 5.1.10). The total elongation of the helium-containing material significantly decreased above $575^{\circ} \mathrm{C}$. At $700^{\circ} \mathrm{C}$ 

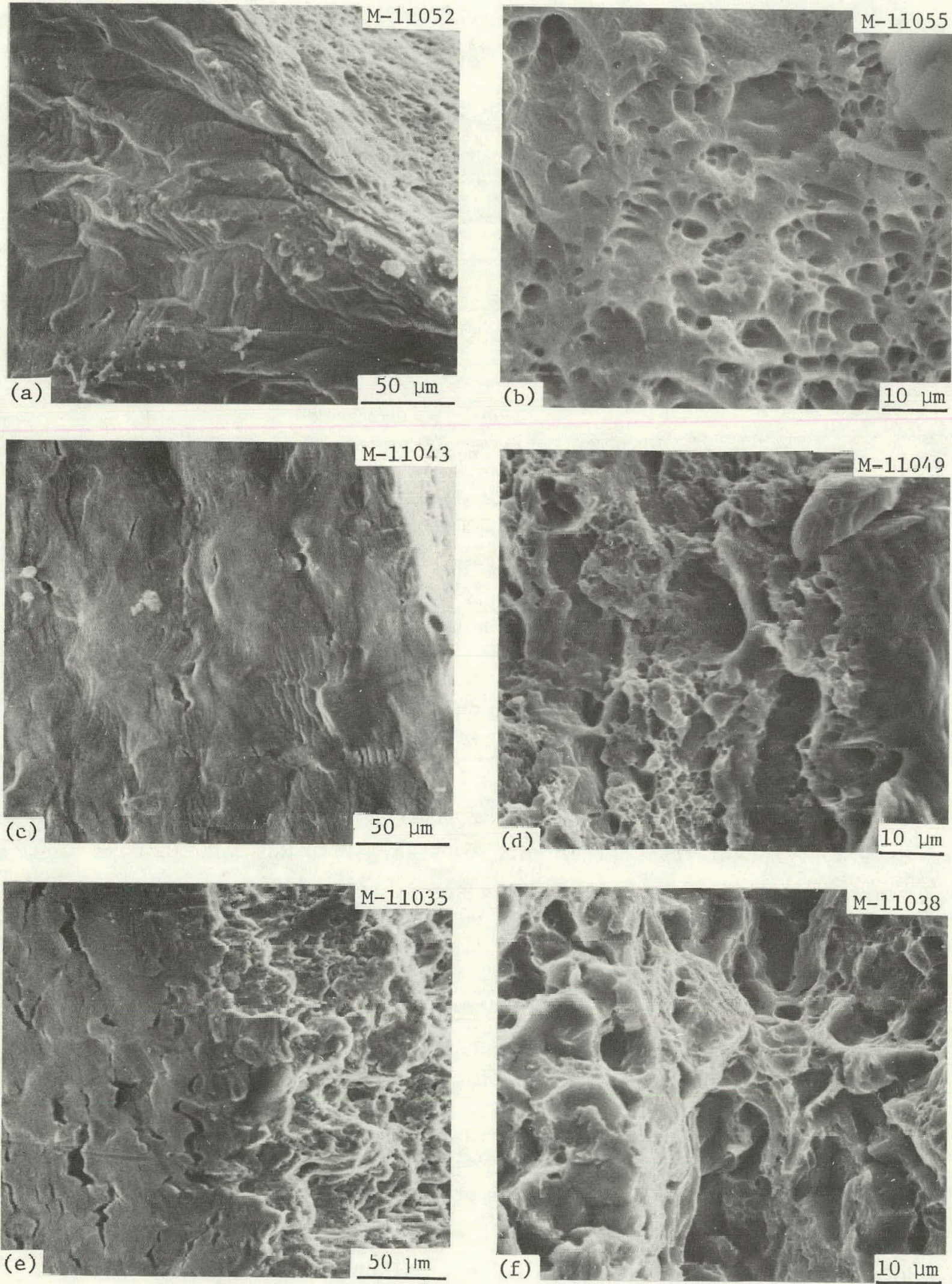

Fig. 5.1.6. Sample Edges Near Fracture (Left) and Surfaces (Right) of $\mathrm{V}-20 \% \mathrm{Ti}$ Specimens Tensile Tested at $700^{\circ} \mathrm{C}$. The specimens were not neutron irradiated. (a) and (b) No helium preinjection. (c) and (d) 90 at. ppm He. (e) and (f) 200 at. ppm He. 


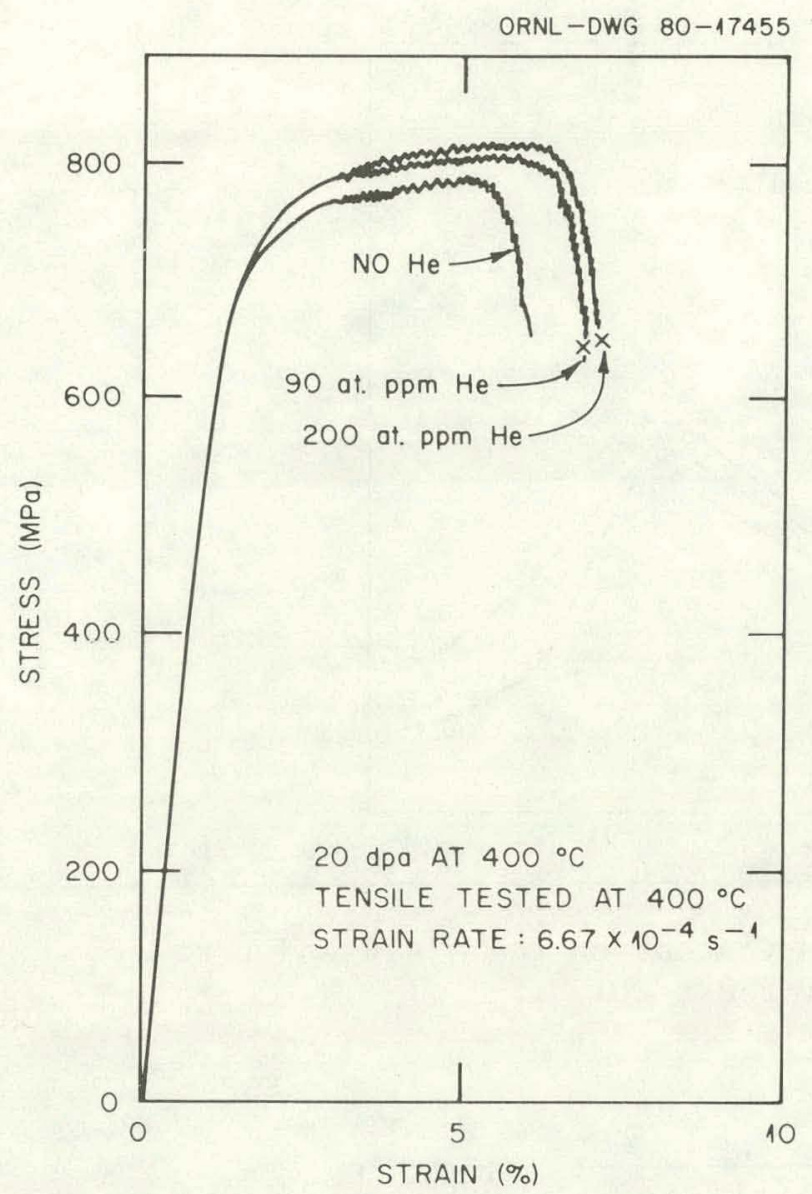

Fig. 5.1.7. Stress-Strain Behavior of Helium-Injected Samples of $\mathrm{V}-20 \% \mathrm{Ti}$ at $400^{\circ} \mathrm{C}$, Following Neutron Irradiation at $400^{\circ} \mathrm{C}$. Tests conducted in vacuum.

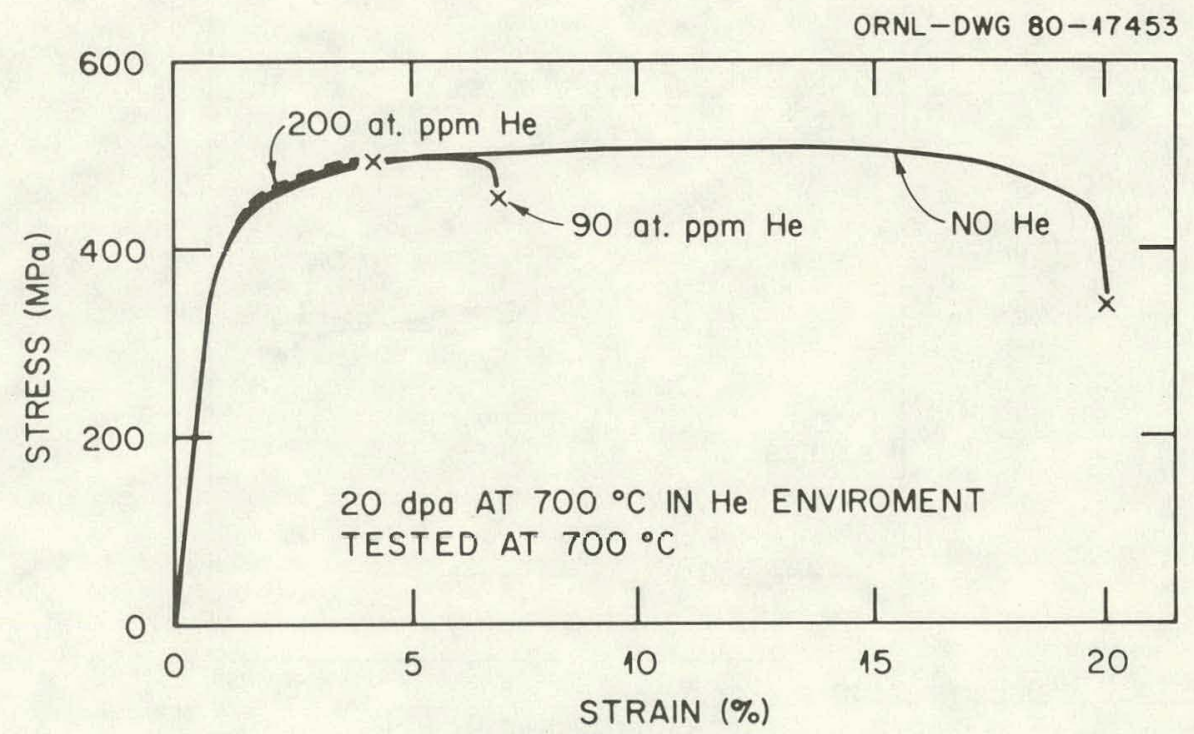

Fig. 5.1.8. Stress-Strain Behavior of Helium-Injected Samples of $\mathrm{V}-20 \% \mathrm{Ti}$ at $700^{\circ} \mathrm{C}$, Following Neutron Irradiation at $700^{\circ} \mathrm{C}$. Tests conducted in vacuum. 


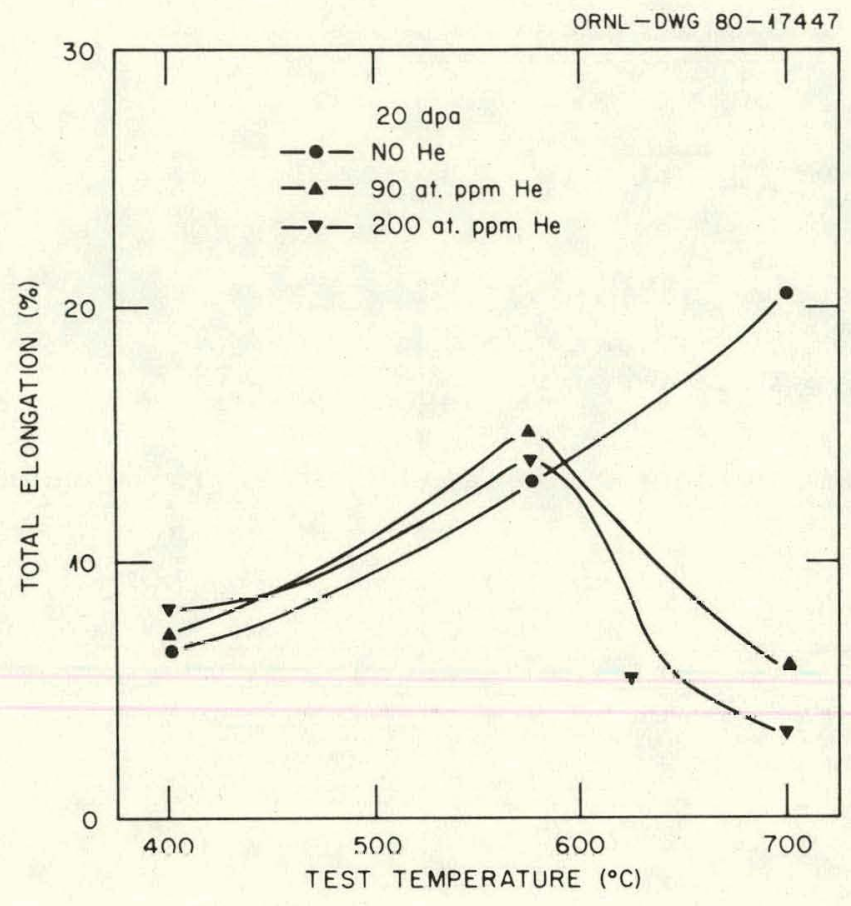

Fig. 5.1.9. Effect of Helium Content on the Yield and Ultimate Tensile Strength of Neutron Irradiated V-20\% Ti.

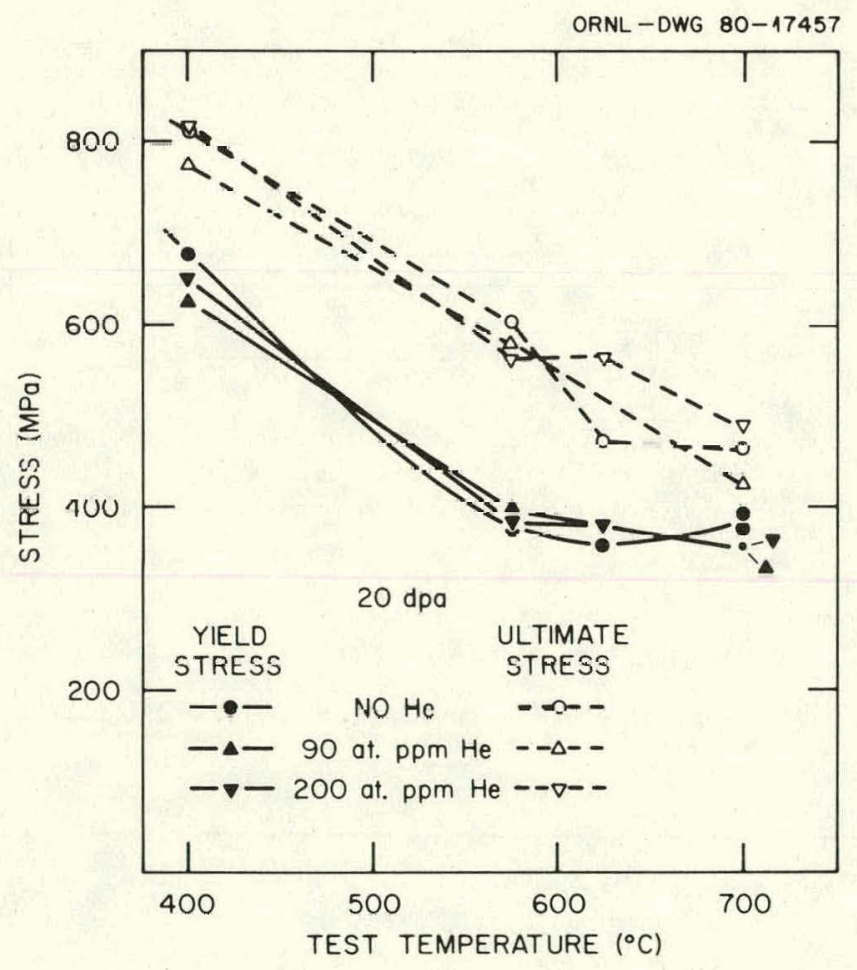

Fig. 5.1.10. Effect of Helium Content on the Total Elongation of Neutron Irradiated V-20\% Ti. 
the total elongations of material injected with 90 and 200 at. ppm He were 6.2 and $3.2 \%$, respectively, which were 29 and $16 \%$ of the helium-free, neutron-irradiated material.

Figure 5.1.11 shows the fracture surfaces of the specimens preinjected with 0, 90, and 200 at. ppm He, following neutron irradiation to approximately $20 \mathrm{dpa}$ and tensile testing at $700^{\circ} \mathrm{C}$. With no preinjection the fracture remained ductile, while with preinjection grain boundary separation became evident. The amount of grain boundary separation increased with helium content and was much greater after neutron irradiation than for samples containing preinjected helium but not neutron irradiated (Fig. 5.1.6). The fracture surface of the specimen injected with 200 at. ppm He shows complete grain boundary separation.

Matrix and grain boundary cavity parameters for both helium-free and helium-preinjected $\mathrm{V}-20 \% \mathrm{Ti}$ specimens after EBR-II irradiation are summarized, respectively, in Tables 5.1.2 and 5.1.3. In the uninjected specimen, cavities developed only at the $400^{\circ} \mathrm{C}$ irradiation temperature, while in preinjected specimens they formed at all irradiation temperatures. The diameter and number density of cavities (Fig. 5.1.12) increased, depending on the amount of preinjected helium.

The microstructures after neutron irradiation at $400^{\circ} \mathrm{C}$ (in static sodium) are shown in Fig. 5.1.13. Rod-shaped precipitate particles (30 $\mathrm{nm}$ long and $3 \mathrm{~nm}$ in diameter), dislocation lines, dislocation loops, and cavities are discernible. The size distribution of cavities in the specimen injected with 200 at. ppm He is clearly bimodal [Fig. 5.1.13(e)]. Large cavities elongated in the $\langle 110\rangle$ direction and attached to the rodshaped precipitate particles are present. The microstructures of the specimens irradiated at $575^{\circ} \mathrm{C}$ in static sodium are shown in Fig. 5.1.14. Dislocation lines and cavities are discernible. The diameter of the cavities on grain boundaries is larger than those in the matrix. Few rodshaped precipitate particles were found. The microstructures of specimens preinjected with 0 and 200 at. ppm He and irradiated at $625^{\circ} \mathrm{C}$ in static sodium are shown in Fig. 5.1.15. Plate-shaped precipitate particles were formed during the neutron irradiation at $625^{\circ} \mathrm{C}$. The composition of these particles has not been fully analyzed but, judging from the diffraction 

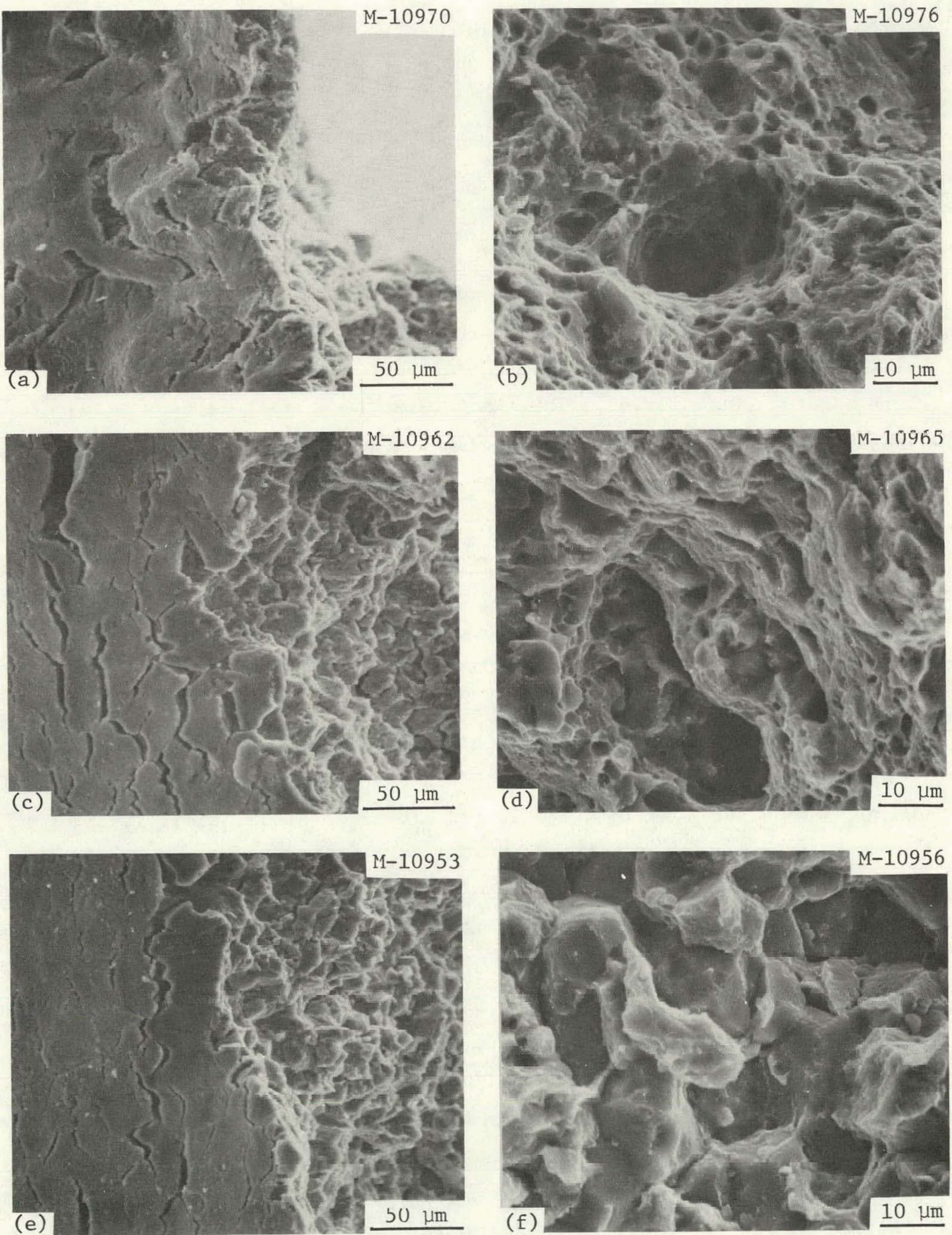

Fig. 5.1.11. Edges of Specimens Near Fracture (Left) and Fracture Surfaces (Right) of V-20\% Ti Tensile Samples Irradiated and Tested at $700^{\circ} \mathrm{C}$. The samples were neutron irradiated in EBR-II (subassembly X-287) to approximately $20 \mathrm{dpa}$. (a) and (b) No helium preinjection. (c) and (d) 90 at. ppm He. (e) and (f) 200 at. ppm He. 
Table 5.1.2. Matrix Cavity Parameters for V-20\% Ti Irradiated in EBR-II to Approximately $20 \mathrm{dpa}$

\begin{tabular}{|c|c|c|c|c|c|c|}
\hline \multirow{3}{*}{$\begin{array}{l}\text { Irradiation } \\
\text { Temperature } \\
\quad\left({ }^{\circ} \mathrm{C}\right)\end{array}$} & \multicolumn{6}{|c|}{$\begin{array}{l}\text { Cavity Parameters for Levels of } \\
\text { Preinjected Helium, at. ppm }\end{array}$} \\
\hline & \multicolumn{3}{|c|}{ Concentration, cavities $/ \mathrm{m}^{3}$} & \multicolumn{3}{|c|}{ Average Diameter, ${ }^{a} \mathrm{~nm}$} \\
\hline & 0 & 90 & 200 & 0 & 90 & 200 \\
\hline 400 & $<1 \times 10^{19}$ & $8.5 \times 10^{20}$ & $1.6 \times 10^{21}$ & $\begin{array}{l}2.7 \\
(2.4-5.4)\end{array}$ & $\begin{array}{l}3.2 \\
(1.6-4.1)\end{array}$ & $\begin{array}{l}7.7 \\
(2.1-16.2)\end{array}$ \\
\hline 575 & $b$ & $1.5 \times 10^{21}$ & $6.1 \times 10^{21}$ & & $\begin{array}{l}3.8 \\
(2.8-4.4)\end{array}$ & $\begin{array}{l}4.9 \\
(3.8-7.6)\end{array}$ \\
\hline 625 & $b$ & $c$ & $5.3 \times 10^{21}$ & & & $\begin{array}{l}5.4 \\
(2.0-6.8)\end{array}$ \\
\hline 700 & $b$ & $8.1 \times 10^{20}$ & $1.7 \times 10^{21}$ & & $\begin{array}{l}6.0 \\
(4.4-8.2)\end{array}$ & $\stackrel{8.2}{(3.8-9.8)}$ \\
\hline
\end{tabular}

$a_{\text {Numbers }}$ in parentheses are range of sizes.

$b_{\text {No }}$ cavities detected.

$c_{\text {No }}$ sample available.

Table 5.1.3. Grain Boundary Cavity Diameters for $\mathrm{V}-20 \% \mathrm{Ti}$ Irradiated in EBR-II to Approximately $20 \mathrm{dpa}$

\begin{tabular}{ccc}
$\begin{array}{c}\text { Irradiation } \\
\text { Temperature } \\
\left({ }^{\circ} \mathrm{C}\right)\end{array}$ & $\begin{array}{c}\text { Average Diameter, } \alpha \mathrm{nm} \text { tor Levels of } \\
\text { Preinjected Helium, at. ppm }\end{array}$ \\
\cline { 2 - 3 } 400 & $b$ & 200 \\
575 & 5.4 & $b$ \\
625 & $(4.4-10.9)$ & $\begin{array}{c}6.0 \\
(3.8-7.6)\end{array}$ \\
700 & $c$ & $\begin{array}{c}6.4 \\
(3.8-7.0)\end{array}$ \\
& 6.0 & 3.2 \\
& $(4.4-8.7)$ & $(2.7-5.4)$ \\
\hline
\end{tabular}

$a_{\text {Numbers }}$ in parentheses are range of sizes.

$b_{\text {No }}$ grain boundary cavities detected.

$c_{\text {No }}$ sample available. 


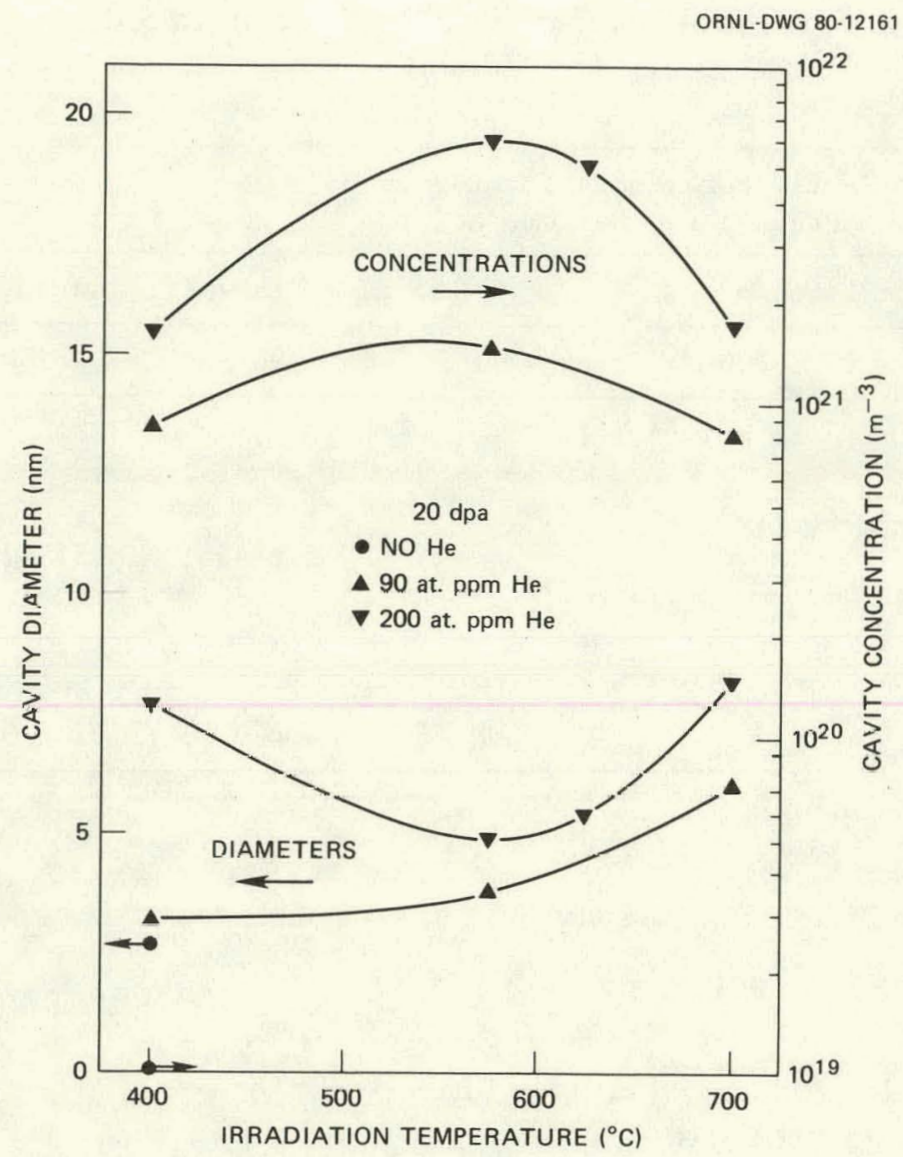

Fig. 5.1.12. The Diameter and Concentration of Matrix Cavities in Neutron-Irradiated V-20\% Ti as a Function of Irradiation Temperature.

pattern, may be $\mathrm{TiO}_{2}$. Cavities formed in the matrix and on grain boundaries in the specimen injected with 200 at. ppm He. The microstructures of the specimens irradiated at $700^{\circ} \mathrm{C}$ in static helium are shown in Fig. 5.1.16. No appreciable precipitates formed during neutron irradiation at $700^{\circ} \mathrm{C}$ and cavities developed only in the helium-injected specimens. Some aligned cavities in the matrix are believed to mark the previous location of a grain boundary, which has since migrated.

\subsubsection{Future Work}

Scanning electron microscopy examination of the rest of the specimens is now in progress. The experimental results presented here will be discussed in more detail next quarter. 

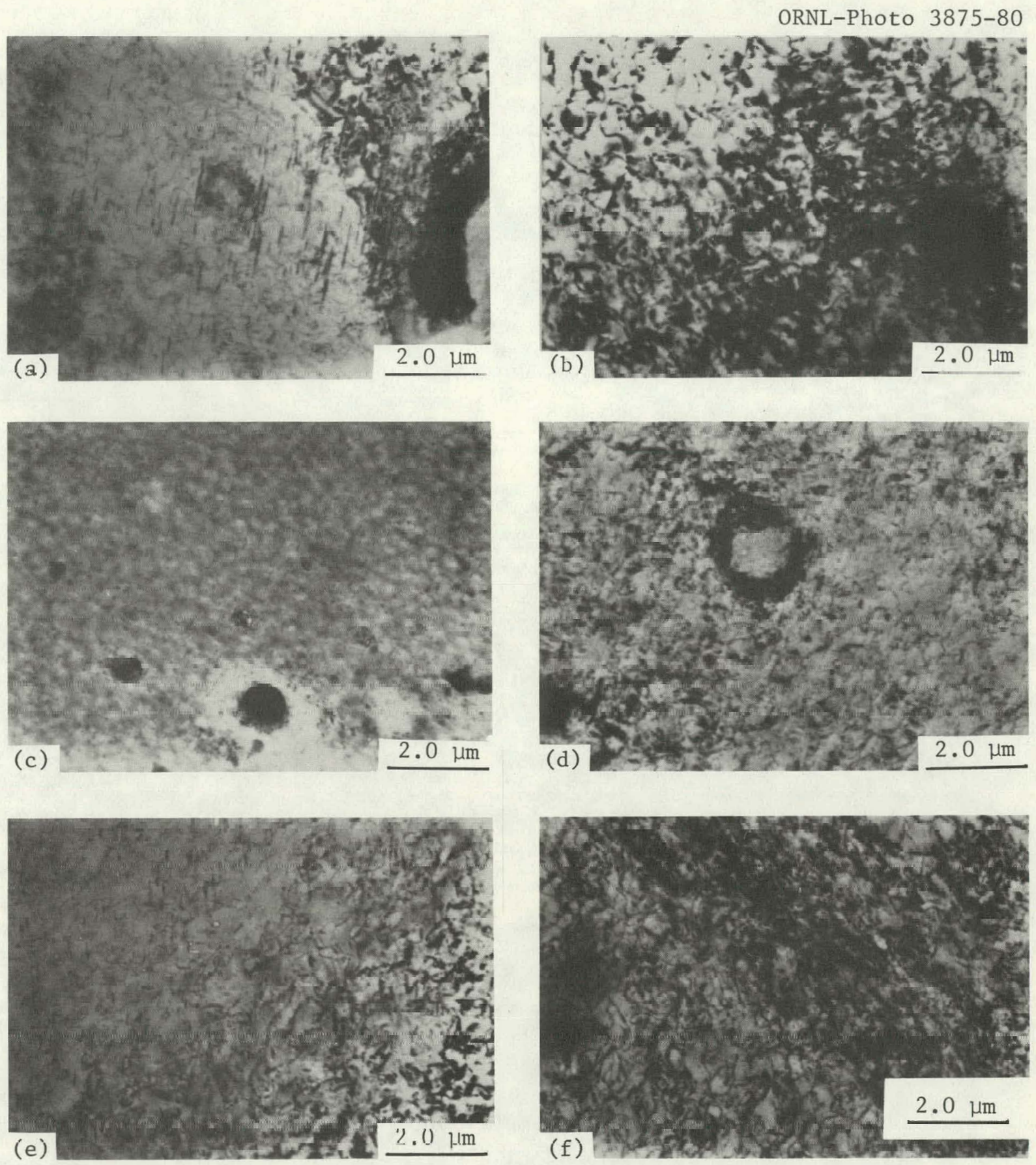

Fig. 5.1.13. The Microstructure of $\mathrm{V}-20 \%$ Ti Irradiated in EBR-II at $400^{\circ} \mathrm{C}$ to $20 \mathrm{dpa}$. (a) and (b) No helium preinjection. (c) and (d) 90 at. ppm He. (c) and (f) 200 at. ppm He. Rod-shaped precipitate particles, dislocation lines, dislocation loops, and cavities are discernible. 
ORNL-Photo $5260-80$
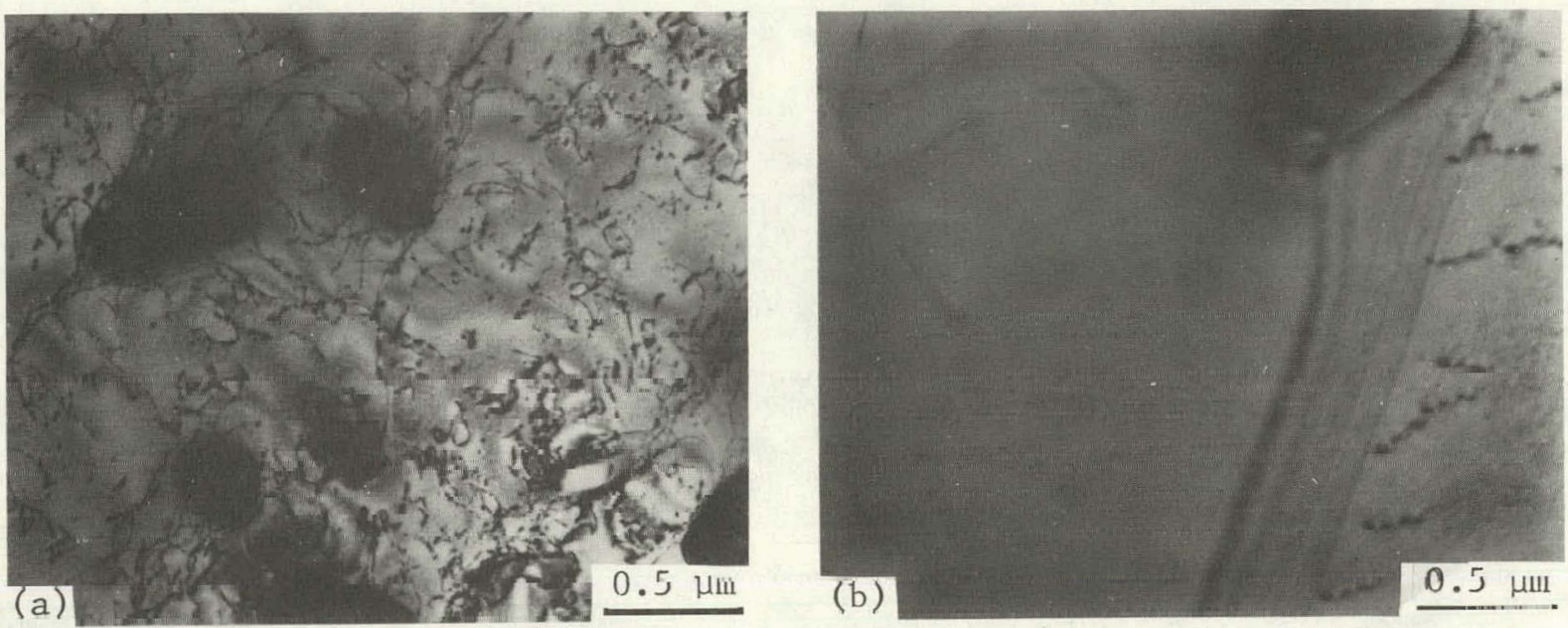

(b)

$0.5 \mu \mathrm{III}$
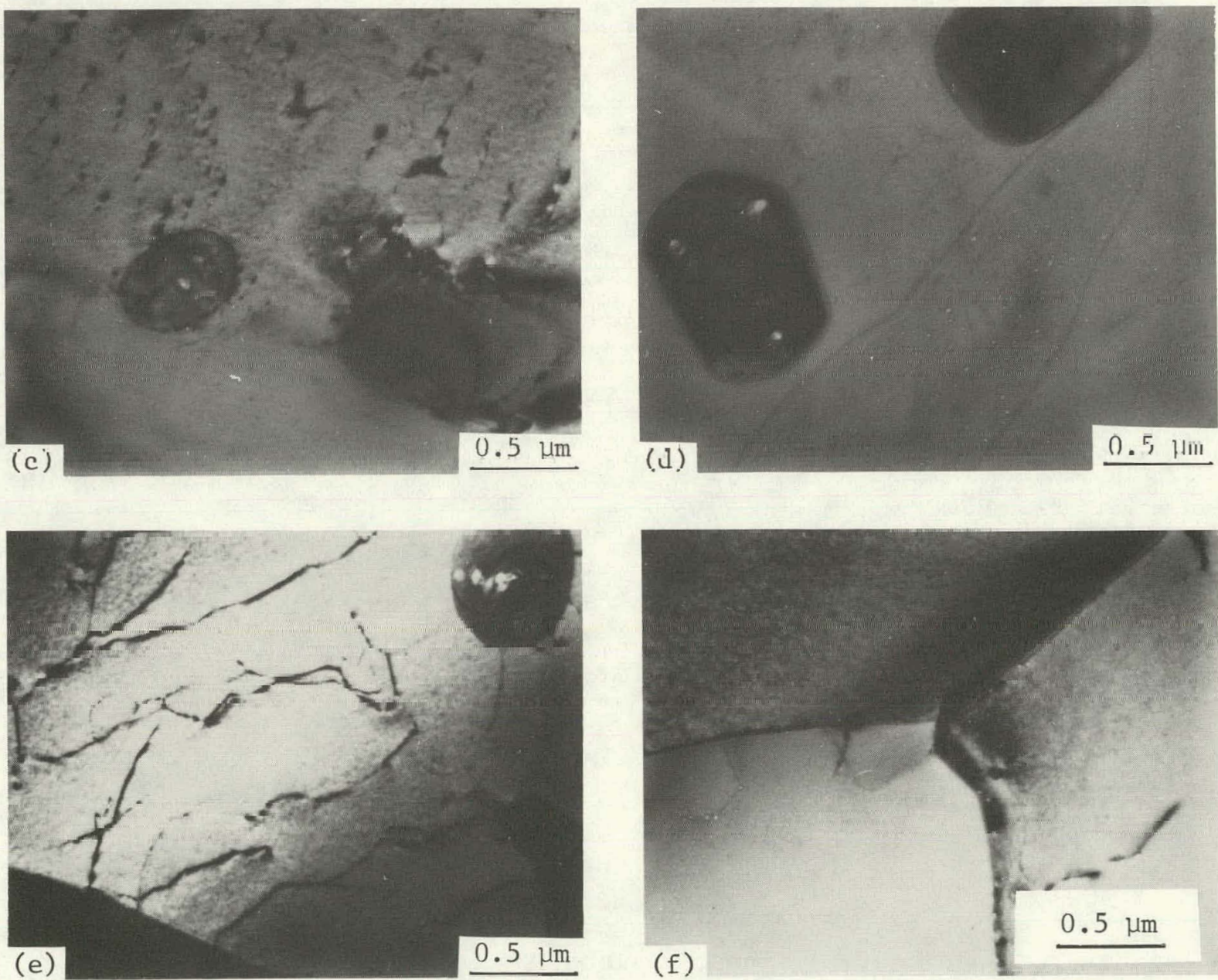

Fig. 5.1.14. Microstructure of $\mathrm{V}-20 \%$ Ti Irradiated at $575^{\circ} \mathrm{C}$ to $20 \mathrm{dpa}$. (a) and (b) No helium preinjection. (c) and (d) 90 at. ppm He. (e) and (f) 200 at. ppm He. Dislocation lines and matrix and grain boundary cavities are visible, but there are no rod-shaped precipitates. 

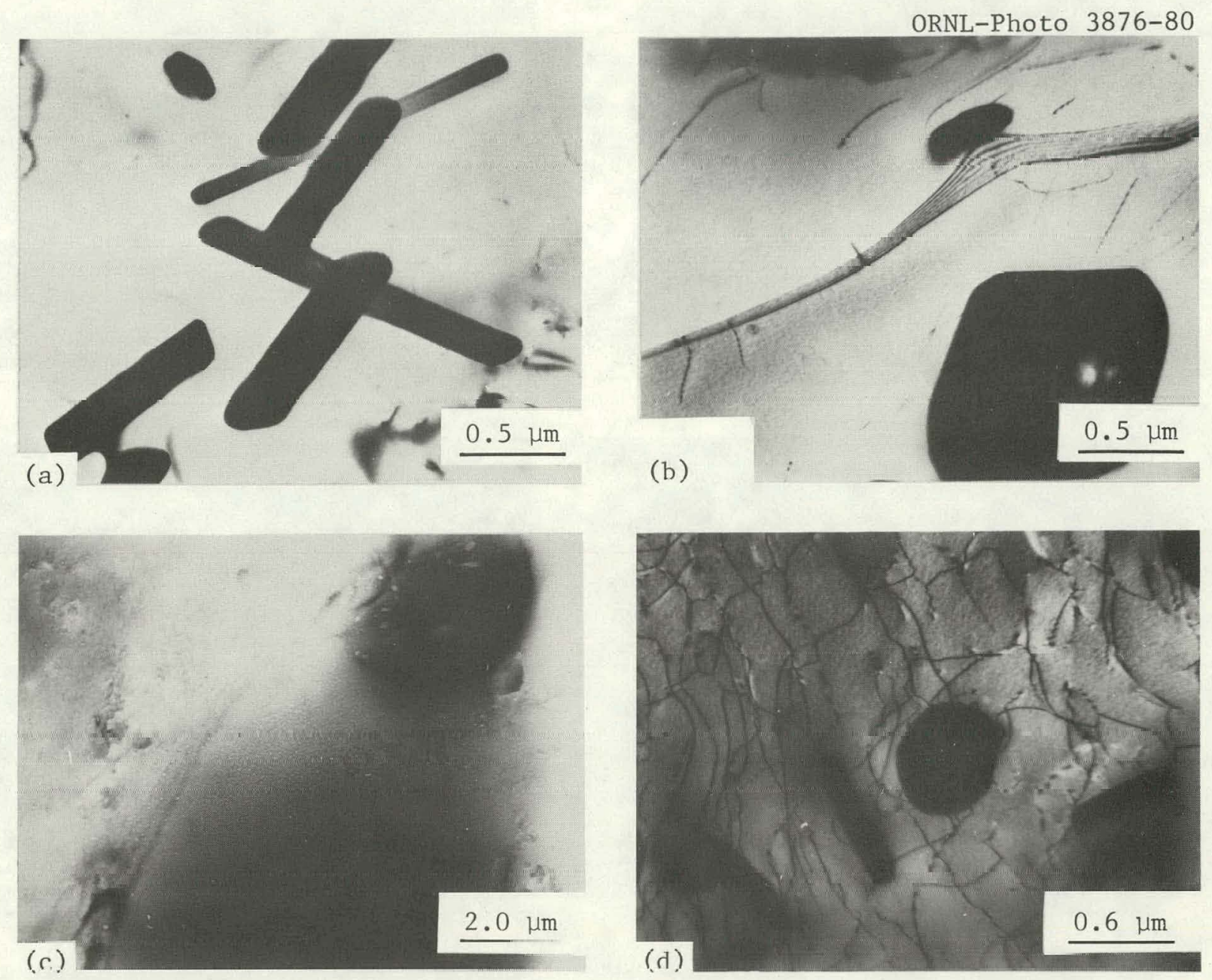

Fig. 5.1.15. The Microstructure of $\mathrm{V}-20 \%$ Ti Irradiated in EBR-II at $650^{\circ} \mathrm{C}$ to $20 \mathrm{dpa}$. (a) and (b) No helium preinjection. (c) and (d) 200 at. ppm He. Plate-shaped precipitate particles, dislocation lines and cavities on grain boundaries, and interface of precipitates are discernible. 

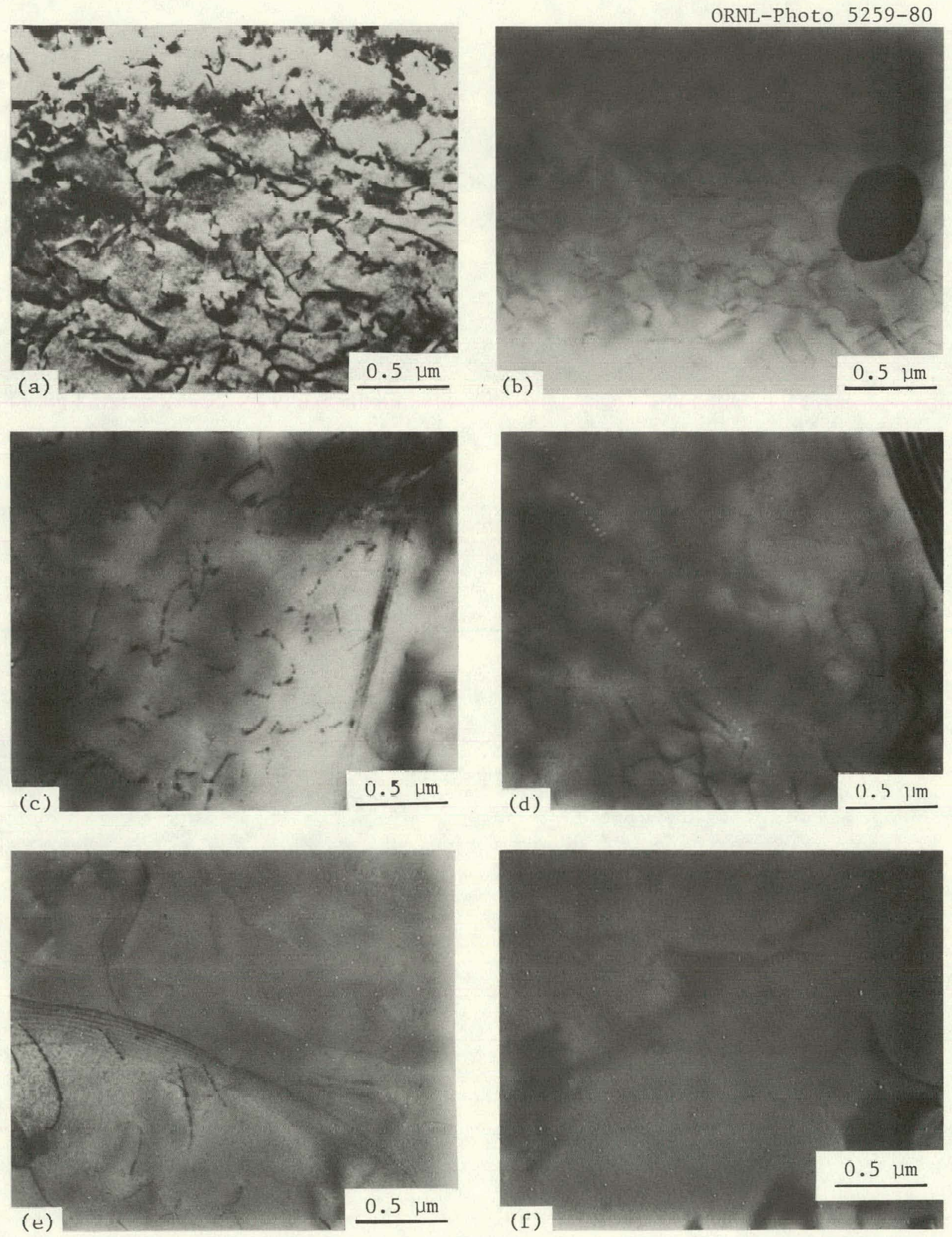

Fig. 5.1.16. Microstructure of $\mathrm{V}-20 \% \mathrm{Ti}$ Irradiated at $700^{\circ} \mathrm{C}$ to 20 dpa. (a) and (b) No helium preinjection. (c) and (d) 90 at. ppm He. (e) and (f) 200 at. ppm He. No appreciable precipitation formed during irradiation, and cavities developed only in helium injected material. 


\subsubsection{References}

1. J. A. Horak, "Helium Implantation in Potential CTR Structural Materials," Controlled Thermonuclear Material Technology Program Annu: Prog. Rep. June 30, 1975, ORNL-5082, pp. 40-42.

2. M. P. Tanaka, J. A. Horak, and E. E. Bloom, "Tensile Properties of Helium-Injected and Reactor-Irradiated V-20\% Ti," ADIP Quart. Prog. Rep. June 30, 1980, DOE/ER-0045/3, pp. 138-45. 
5.2 FATIGUE BEHAVIOR OF UNIRRADIATEd $\vee-15 \%$ Cr-5\% Ti. - K. C. Liu (ORNL)

\subsubsection{ADIP Task}

ADIP Task I.B.3, Fatigue Crack Growth in Reactive and Refractory Alloys.

\section{2 .2 Objective}

The objective of this work is to develop baseline fatigue and crack growth data for the Path $C$ refractory metal scoping alloys in the. unfradiated condition.

\section{2 .3 Summary}

Fully reversed cyclic fatigue tests conducted on $\mathrm{V}-15 \% \mathrm{Cr}-5 \% \mathrm{Ti}$ ( $\mathrm{ADIP}$ heat CAM-835 $\mathrm{B}-3$ ) in the unirradiated condition at 25, 550, and $650^{\circ} \mathrm{C}$ indicated an apparent endurance limit at total strain ranges of about 0.7 and $0.6 \%$ at 550 and $650^{\circ} \mathrm{C}$, respectively.

\subsubsection{Progress and Status}

Cyclic fatigue tests on $\mathrm{V}-15 \% \mathrm{Cr}-5 \% \mathrm{Ti}$ were continued with ten tests completed to date. A detailed description of specimens, test method, and test conditions has been presented previously. 1,2

The results of the tests are summarized in Table 5.2.1 and plotted in Fig. 5.2.1. A number of these samples failed outside the gage section. The location of these fractures are shown in Fig. 5.2.2.

By making use of the limited data available to date, we can reasonably correlate fatigue lifetime with cyclic strain range, as shown in Fig. 5.2.1. Specimens that did not fail at the minimum cross section were indicated with arrows pointing toward the right. Failures of these specimens outside the test section show that in high cycle fatigue this alloy is sensitive to variations in mean stress and/or the presence of stress raisers. Broken lines indicate approximate behavior since none of the tests below $1 \%$ strain range failed within the gage section.

In view of the indication from the trend curves shown in Fig. 5.2.2, we have revised the tentative test schedule discussed in the last report, ${ }^{2}$ as shown in Table 5.2.2. 


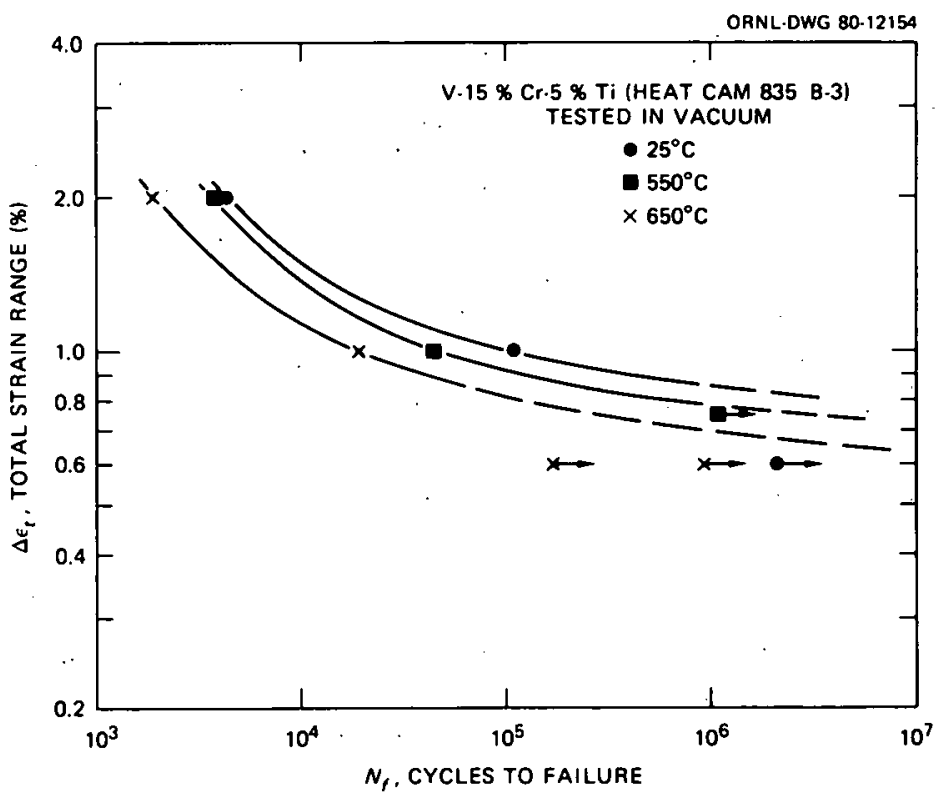

Fig. 5.2.1. Cyclic Fatigue Data for $\mathrm{V}-15 \% \mathrm{Cr}-5 \%$ Ti Tested at 25, 550 , and $650^{\circ} \mathrm{C}$ in Vacuum.

Table 5.2.1. Fatigue Lifetime Test Data for. $-15 \% \mathrm{Cr}-5 \% \mathrm{Ti} \dot{a}$.

\begin{tabular}{|c|c|c|c|c|c|c|}
\hline Specimen & $\begin{array}{c}\text { Test } \\
\text { Temperature } \\
\left({ }^{\circ} \mathrm{C}\right)\end{array}$ & $\begin{array}{l}\text { Total } \\
\text { Strain } \\
\text { Range } \\
(\%)\end{array}$ & $\begin{array}{l}\text { Maximum } \\
\text { Total } \\
\text { Stress } \\
\text { Cyclic } \\
\text { Range } \\
\text { (MPa) }\end{array}$ & $\begin{array}{l}\text { Cycles } \\
\text { to } \\
\text { Fallure }\end{array}$ & $\begin{array}{l}\text { Time to } \\
\text { Failure } \\
\text { (h) }\end{array}$ & Comments \\
\hline $\begin{array}{ll}\text { AV } & 53 \\
\text { AV } & 51 \\
\text { AV } & 52\end{array}$ & $\begin{array}{l}27 \\
27 \\
27\end{array}$ & $\begin{array}{l}2.0 \\
1.0 \\
0.6\end{array}$ & $\begin{array}{l}670 \\
600 \\
415\end{array}$ & $\begin{array}{r}4,345 \\
109,125 \\
>2,047,020\end{array}$ & $\begin{array}{l}12.1 \\
151.6 \\
816\end{array}$ & $b$ \\
\hline $\begin{array}{ll}\text { AV } & 510 \\
\text { AV } & 58 \\
\text { AV } & 511\end{array}$ & $\begin{array}{l}550 \\
550 \\
550\end{array}$ & $\begin{array}{l}2.0 \\
1.0 \\
0.75\end{array}$ & $\begin{array}{l}620 \\
540 \\
460\end{array}$ & $\begin{array}{r}3,783 \\
43,555 \\
>1,072,110\end{array}$ & $\begin{array}{l}10.5 \\
60.5 \\
573\end{array}$ & i \\
\hline $\begin{array}{ll}\text { AV } & 54 \\
\text { AV } & 56 \\
\text { AV } & 55 \\
\text { AV } & 57\end{array}$ & $\begin{array}{l}650 \\
650 \\
650 \\
650\end{array}$ & $\begin{array}{l}2.0 \\
1.0 \\
0.6 \\
0.6\end{array}$ & $\begin{array}{l}614 \\
540 \\
360 \\
360\end{array}$ & $\begin{array}{r}1,874 \\
19,452 \\
>171,539 \\
>951,302\end{array}$ & $\begin{array}{l}5.2 \\
27.1 \\
143 \\
792\end{array}$ & $\begin{array}{l}d \\
e\end{array}$ \\
\hline
\end{tabular}

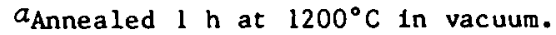

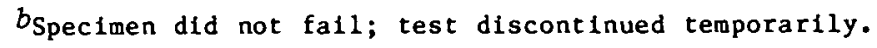

$c_{\text {Test }}$ switched from strain control to load control after 253,000 cycles; specimen did not fall in gage section but broke at the end of the shniliter, as shown in Fig. 5.2.2.

$d$ Specimen did not fall in gage section; crack initiated at the shoulder where a thermocouple was spot-welded, as indicated in F1g. 5.2.2.

$e_{\text {Test }}$ switched from strain control to load control after 500,000 cycles at high frequency. Specimen did not fall at gage section but broke at the end thread, as shown in Fig. 5.2.2. 
ORNL-DWG 80.12150

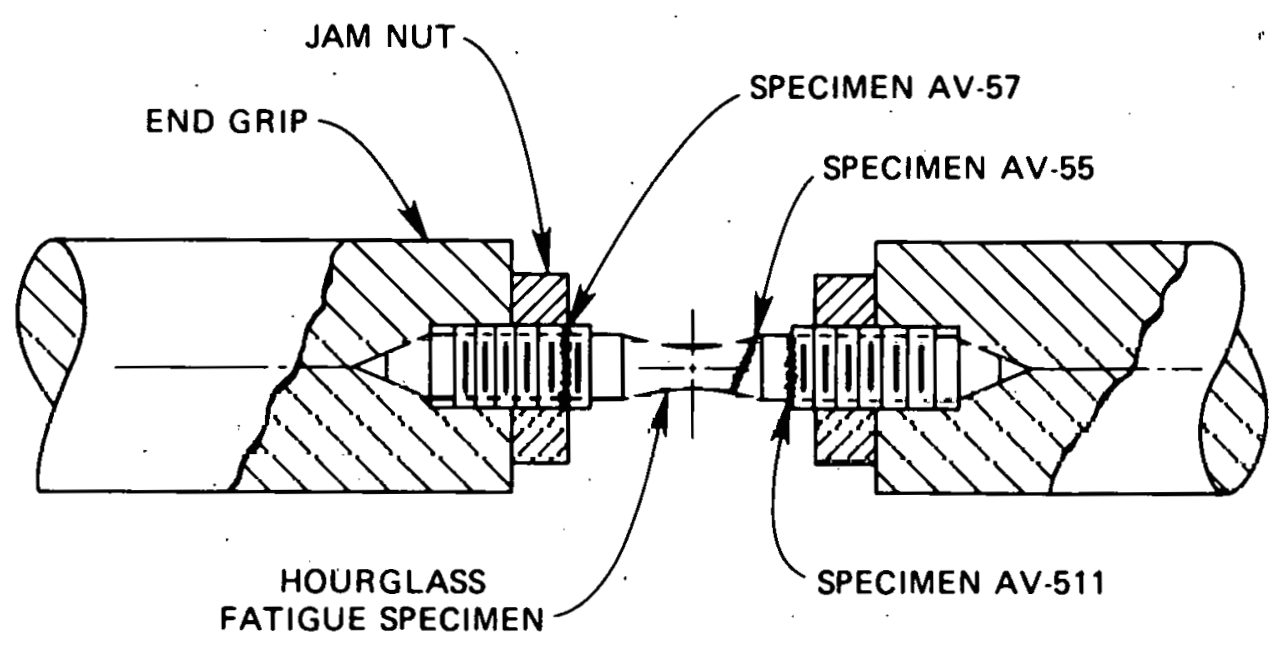

Fig. 5.2.2. Locations of Specimen Fractures Outslde Gage Section.

Table 5.2.2. Revised Test Schedule ${ }^{a}$ for $\mathrm{V}-15 \% \mathrm{Cr}-5 \% \mathrm{Ti}$

\begin{tabular}{|c|c|c|c|c|c|c|c|c|}
\hline \multirow{2}{*}{$\begin{array}{l}\text { Temperaturc } \\
\left({ }^{n} \mathrm{C}\right)\end{array}$} & \multicolumn{8}{|c|}{ Total Strain Range, $\%$} \\
\hline & 2.0 & 1.0 & 0.9 & 0.8 & 0.75 & 0.7 & 0.65 & 0.6 \\
\hline 25 & $\mathrm{C}$ & $\mathrm{C}$ & $\star$ & $*$ & & & & IC \\
\hline 550 & $\mathrm{C}$ & C & & $*$ & IC & * & & \\
\hline 650 & C & C & & * & & $*$ & * & IC \\
\hline
\end{tabular}


The revised test matrix is intended to fill in gaps between 1.0 and $0.6 \%$ strain ranges, thereby permitting more effective definition of the fatigue life behavior. To avoid failure of specimens outside the test section, procedures for specimen preparation and installation in the test rig have been reviewed. Special care will be exercised to avoid imposing excessive strain in the specinen shoulder and threads.

Figure 5.2 .1 shows that the fatigue lifetime of $\mathrm{K}-15 \% \mathrm{Cr}-5 \% \mathrm{Ti}$ decreases as temperature increases. Nevertheless, the alloy exhibits superior fatigue resistant properties at $650^{\circ} \mathrm{C}$ in comparison with several other ${ }^{3}$ inaterials, as shown in Fig. 5.2.3. (Note, however, that only the vanadium alloy tests were conducted in vacuum. Thus the alloy comparison is only qualitative.)

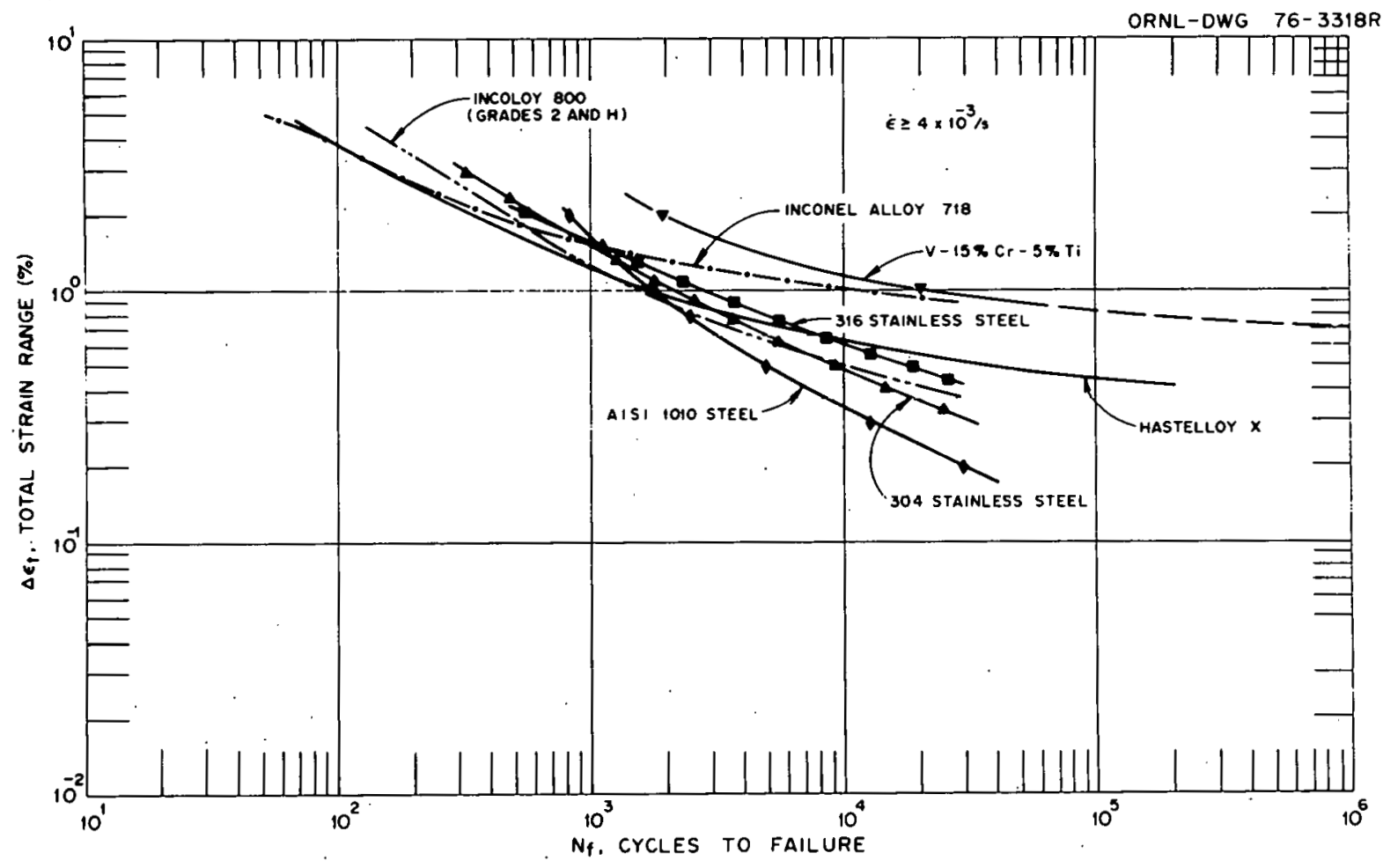

Fig. 5.2.3. Comparison of Fatigue Behavior of Several Materials and $\mathrm{V}=15 \% \mathrm{Cr}-5 \% \mathrm{Ti}$ Teeted at $650^{\circ} \mathrm{C}$. The vanadium alloy wao teoted in vacuum; all other tests were conducted in air. Source of data: C. R. Brinkman et al., Application of Hastelloy $X$ in Gas-Cooled Reactor Systems, ORNL/ TM-5405 (October 1976). 


\subsubsection{Conclusions}

Limited data obtained to date indicate that annealed $\mathrm{V}-15 \% \mathrm{Cr}-5 \% \mathrm{Ti}$ at $650^{\circ} \mathrm{C}$ has superior fatigue resistance in comparison with several other structural materials commonly used in fission reactors. The results further suggest that endurance limits may exist at strain ranges of approximately 0.7 and $0.6 \%$ at 550 and $650^{\circ} \mathrm{C}$, respectively.

\subsubsection{References}

1. K. C. Liu, "Mechanical Property Testing of Unirradiated Path C Alloy," ADIP Quart. Prog. Rep. Sept. 30, 1979, DOE/ET-0058/7, pp. 141-43.

2. K. C. L1u, "Fat1gue Behavior of Unirradiated Path C Alloys," ADIF Quxit. Frog. Rep. Junt 30, 1900, DOE/ER.0045/3, pP. 146-52.

3. C. R. Brinkman et 31., Appliaation of Hactolloy $X$ in Gae-Coolod Reactor Systems, ORNL/TM-5405 (October 1976). 
5.3 THE EFFECT OF HYDROGEN ON FLAW GROWTH OF TITANIUM ALLOY Ti-6242S G. W. Wille and P. S. Pao (McDonnell Douglas Corporation)

\subsubsection{ADIP Task}

Task 1.B.3, Fatigue Crack Growth in Reactive/Refractory Alloys (Path C).

\subsubsection{Objective}

The objective of this study is to develop quantitative data to determine the effects of both internal and external hydrogen on fatigue crack growth of Ti-6242S alloy at temperatures and hydrogen pressures of interest for fusion reactors.

\section{3 .3 Summary}

Initial fatigue crack growth rate tests have been conducted at room and elevated temperatures with environment hydrogen pressures from 0 to $100 \mathrm{~Pa}$ ( 0.75 torr) on Ti-6242S samples containing 50 and 500 wppm interna1 hydrogen. These tests indicate that at room temperature there is an increase in the crack growth rate with the 500 wppm hydrogen content; no effect of environment hydrogen pressure was noted. Tests conducted at elevated temperatures indicate a decrease in crack growth rate with higher temperatures.

\subsubsection{Progress and Status}

Twelve fatigue crack growth rate tests have been run with the parameters shown in Table 5.3.1. Figure 5.3.1 is a plot of the results of tests 1 through 6 . The first six tests indicate that at room temperature $\left(17^{\circ} \mathrm{C}\right)$ there is no significant effect on the crack growth rate due to varying the environment hydrogen pressure from zero to $100 \mathrm{~Pa}(0.75$ torr). The variations in crack growth rates due to environment hydrogen pressure fall within the bands indicated in the figure. There is an increase in crack growth rate with the 500 wppm internal hydrogen content as compared to $50 \mathrm{wppm}$ internal hydrogen content. It is interesting to note that for stress intensity factors, $\Delta K$, less than approximately $25 \mathrm{MPa}^{1 / 2}$ there is no difference in the range of crack growth 
rates for the 50 or 500 wppm internal hydrogen contents.

Table 5.3.1 Test Parameters

$\mathrm{R}=0.1$, Frequency $=5$ Hertz

\begin{tabular}{|c|c|c|c|c|c|c|c|c|c|}
\hline Test & \multicolumn{2}{|c|}{$\begin{array}{l}\text { Internal } \mathrm{H} \\
\text { Content, wppm }\end{array}$} & \multicolumn{3}{|c|}{$\begin{array}{l}\text { Environment } \mathrm{H} \\
\text { Pressure, } \mathrm{Pa}\end{array}$} & \multicolumn{4}{|c|}{$\begin{array}{c}\text { Test Temperature, } \\
{ }^{\circ} \mathrm{C}\end{array}$} \\
\hline & 50 & 500 & 0 & 13.3 & 100.0 & 17 & 80 & 150 & 200 \\
\hline 1 & $\mathrm{X}$ & & $\underline{X}$ & & & $X$ & & & \\
\hline 2 & $X$ & & & $X$ & & $\mathrm{X}$ & & & \\
\hline 3 & $\mathrm{X}$ & & & & $\mathrm{X}$ & X & & & \\
\hline 4 & & $x$ & $X$ & & & $\mathrm{X}$ & & & \\
\hline 5 & & $\mathrm{X}$ & & $X$ & : & $x$ & & & \\
\hline 6 & & $\mathrm{X}$ & & & $X$ & $x$ & & & \\
\hline 7 & $X$ & & $X$ & & & & $X$ & & \\
\hline 8 & $X$ & & $X$ & & & & & $X$ & \\
\hline 9 & $\mathrm{X}$ & & $x$ & & & & & & $X$ \\
\hline 10 & & $X$ & $X$ & & & & $X$ & & \\
\hline 11 & & $\mathrm{X}$ & $X$ & & & & & $\mathrm{X}$ & \\
\hline 12 & & $\mathrm{X}$ & $\mathrm{X}$ & & & & & & $X$ \\
\hline
\end{tabular}

Tests 7 through 12 evaluated the effects of elevated temperature on the crack growth rate. Figures 5.3 .2 and 5.3 .3 show the results of these tests. The crack growth rate with 50 wppm internal hydrogen content decreased at low stress intensities when tested at temperatures above $80^{\circ} \mathrm{C}$, however there was no effect at the high $\left(80 \mathrm{MP}-\mathrm{m}^{1 / 2}\right)$ ctrcsa intensities. 'l'ests conducted at 500 wppm internal hydrogen content indicate that the elevated temperatures lower the fatigue crack growth rate, even at the higher stress intensity factors: A diruct comparicon of tests conducted at $150^{\circ} \mathrm{C}$, Figure 5.3.4, shows only a slightly higher crack growth rate with an internal hydrogen content of 500 wppm, whereas at room temperature the rate was considerably higher for the material with 500 wppm hydrogen (see Figure 5.3.1).

At this point in time no in-depth analysis of the data has been conducted, and therefore no discussion will be presented. Analysis of the existing data and examination of fracture surfaces is planned during the next quarter. 


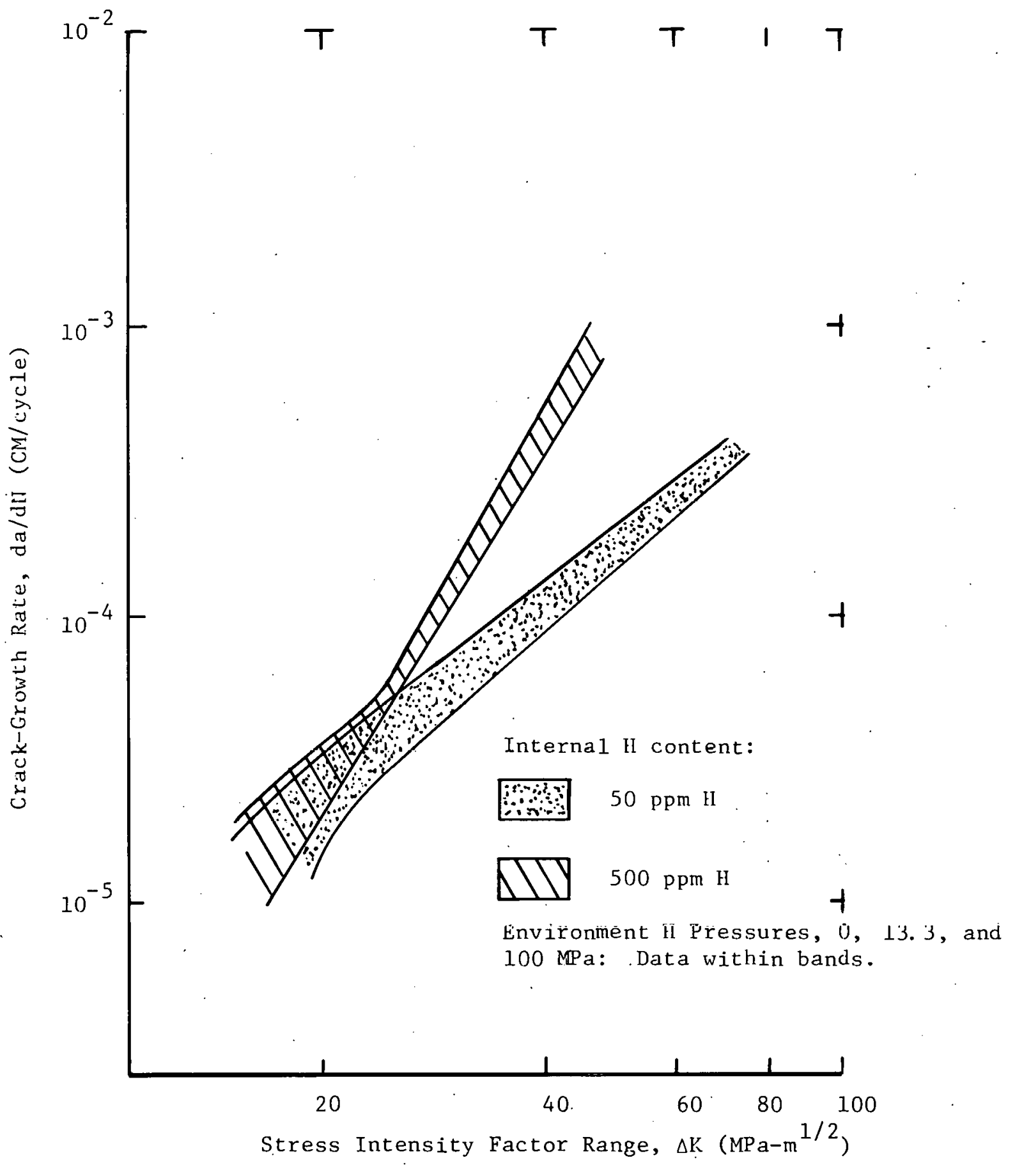

Figure 5.3.1 Effect of Internal and Environment Hydrogen on the Fatigue-Crack-Growth Rate of Ti-6Al-2Sn-4Zr-2Mo-Si at Room Temperature 


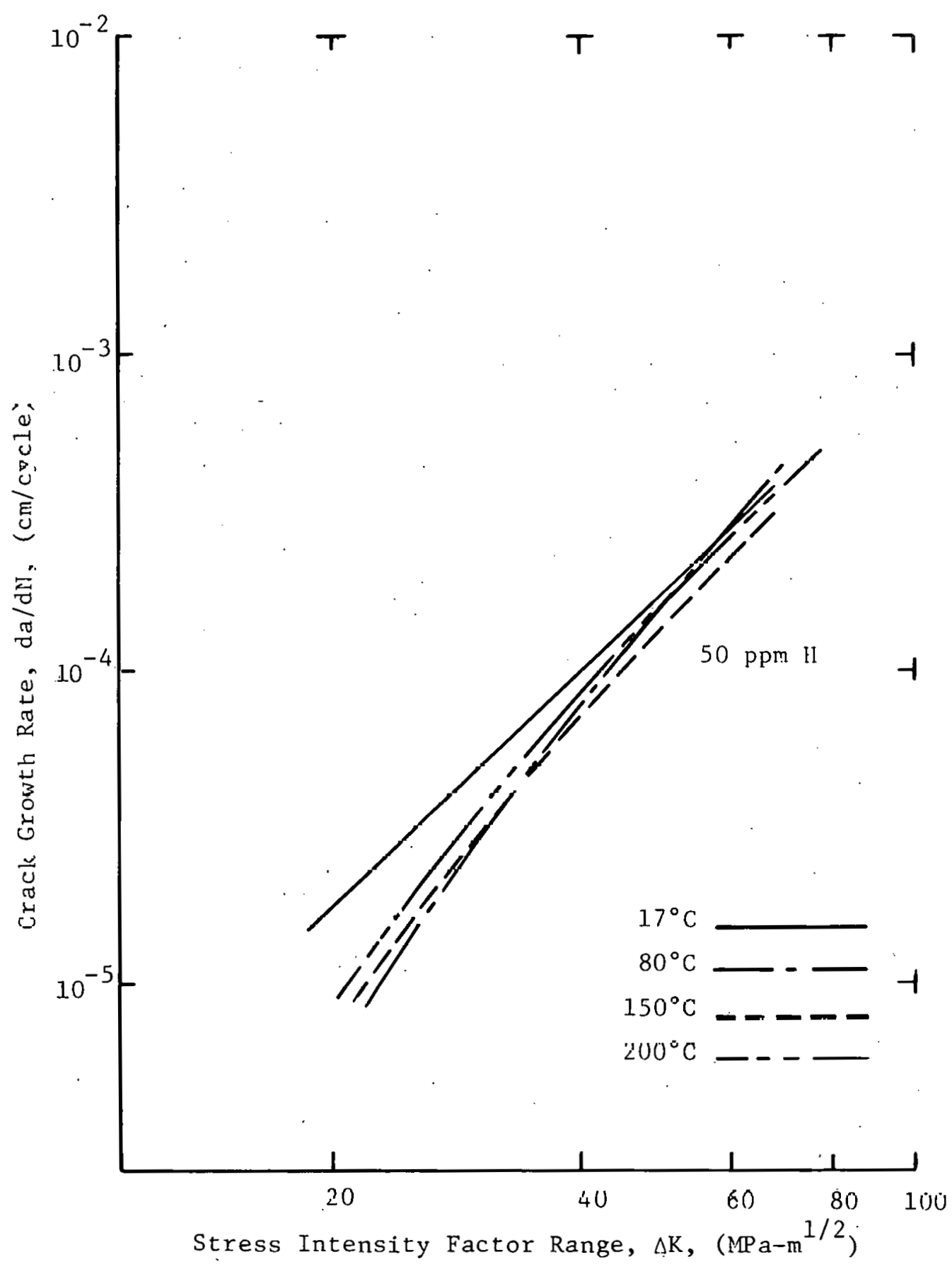

Figure 5.3.2 The Fiffert of Temperature on the Fatigue Crack Growth Rate of $\mathrm{Ti}-6242 \mathrm{~S}$ with 50 wppm Internal Hydrogen 


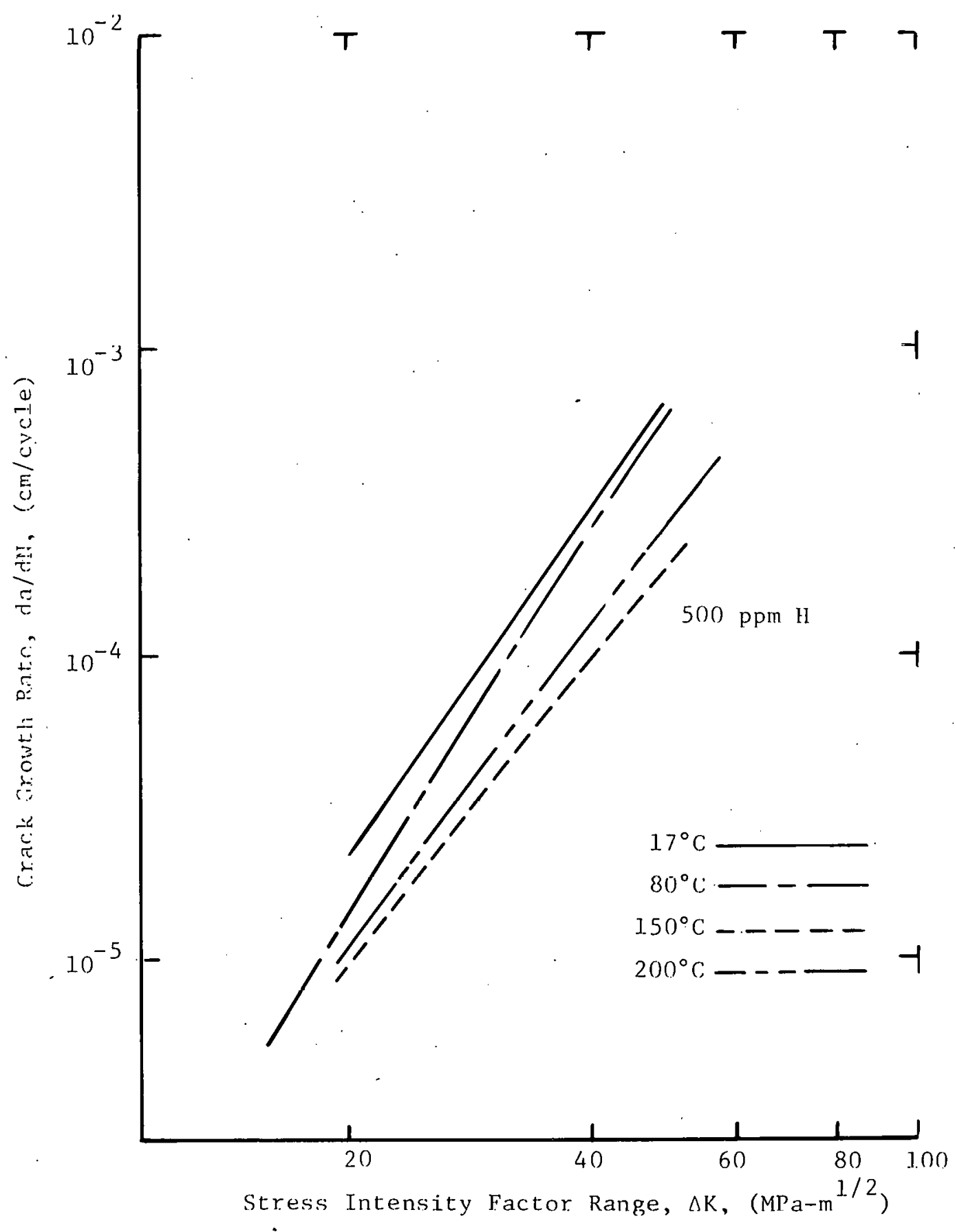

Figure 5.3.3 The Effect of Temperature on the Fatigue Crack Growth Rate of Ti-6242S with 500 wpm Internal Hydrogen 


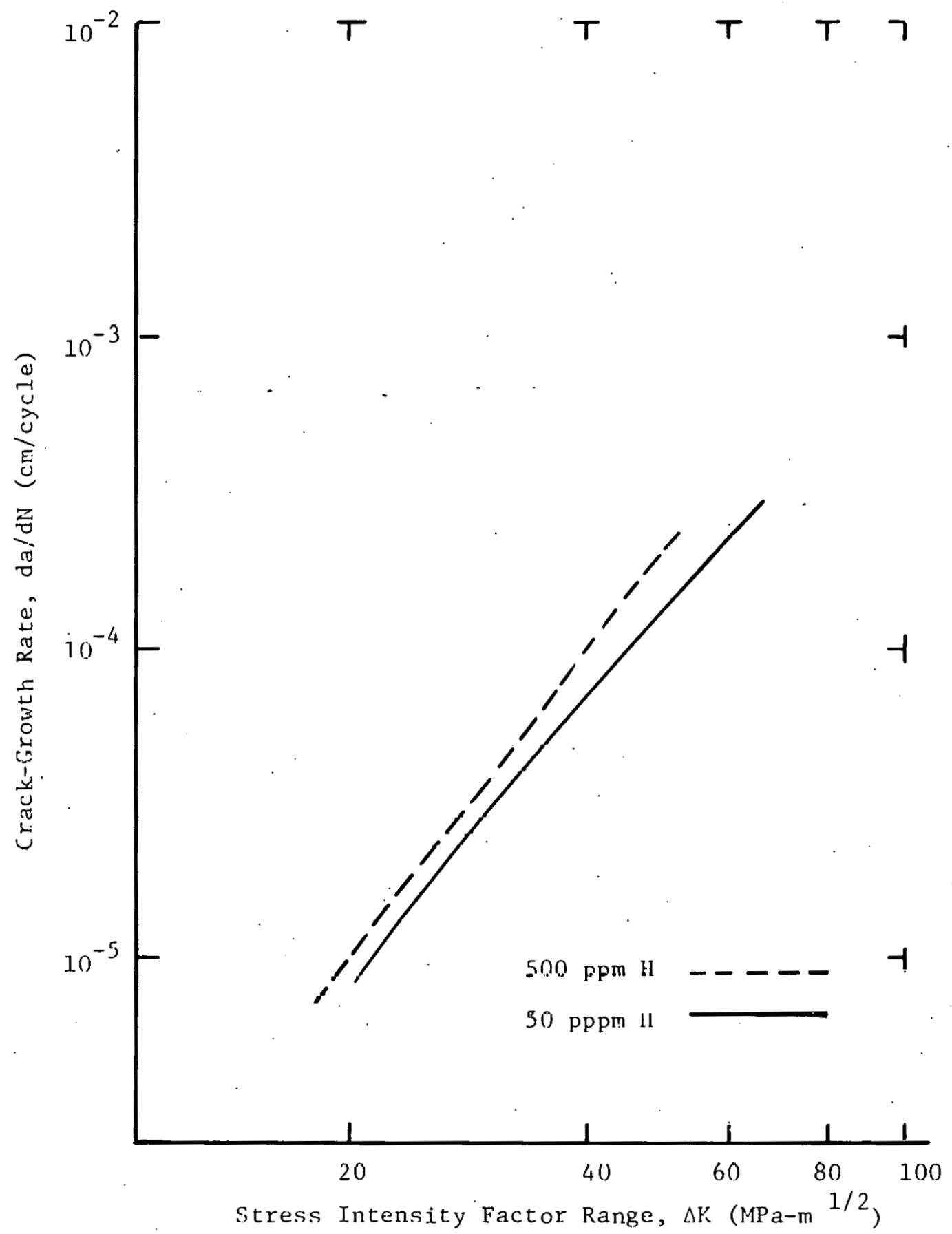

Figure 5.3.4 Effect of Internd llydrogen Concentration on the Fatigue-Crack-Crowth Rates of $\mathrm{Ti}-6242 \mathrm{~S}$ at $150^{\circ} \mathrm{C}$ 


\subsubsection{Conclusions}

Initial tests indicate the following:

1. There is no effect on fatigue crack growth rate at room temperature from environment hydrogen pressure.

2. There is an increase in crack growth rate at room temperature with internal hydrogen content of 500 wppm vs. 50 wppm.

3. At elevated test temperatures there is a decrease in crack growth rate with higher temperature. 
112

THIS PAGE

WAS INTENTIONALLY

LEFT BLANK 
113

6. PATH D ALlOY DEVELOPMENT - INNOVATIVE MATERIAL CONCEPTS 
6.1 THE EFFECT OF 4-MeV NICKEL ION IRRADIATION ON THE MICROSTRUCTURE OF $(\mathrm{Fe}, \mathrm{Ni}){ }_{3} \mathrm{~V}$ LONG-RANGE-ORDERED ALLOYS - D. N. Braski (ORNL)

\section{1 .1 ADIP Task}

ADIP Task I.C.5, Microstructure and Swelling in Special and Innovative Materials.

\section{1 .2 Objective}

The objective of this research is to define the response of a new class of $(\mathrm{Fe}, \mathrm{Ni})_{3} \mathrm{~V}$ long-range-ordered (LRO) alloys to both neutron and ion irradiation. The overall goal is to determine the potential use of this alloy class as a structural material for fusion energy systems.

\section{1 .3 Summary}

The $(\mathrm{Fe}, \mathrm{Ni})_{3} \mathrm{~V}$ LRO alloys investigated are relatively resistant to swelling when irradiated with $4-\mathrm{MeV}(0.64-\mathrm{pJ})$ nickel ions to $70 \mathrm{dpa}$ in the range 525 to $680^{\circ} \mathrm{C}$ and simultaneously injected with 8 at. ppm He and 28 at. ppm D per dpa. Small titanium additions appear to improve the resistance to swelling, but it is not certain whether this effect depends strictly on titanium or is related to the removal of sigma phase from the microstructure. All the LRO alloys retained their order for irradiation temperatures below the critical ordering temperature of about $670^{\circ} \mathrm{C}$. However, long range order in itself did not appear to be the dnminant factor determining swelling resistance.

\section{1 .4 Progress and Status}

\section{1 .4 .1 Int roduction}

A new alloy, LRo-20, that does nọt furlu sigmid phase has been fäbricated and irradiated with 4-MeV nickel ions to $70 \mathrm{dpa}$. We had hoped that preventing the formation of sigma phase (which was found in the LRO-16 material ${ }^{1}$ ) would improve the resistance of the $(\mathrm{Fe}, \mathrm{Ni})_{3} \mathrm{~V}$ alloys to radiation damage. A second new alloy, LRO-37, having the same compusition as LRO-20 but with a 0.4 wt \% Ti addition, has also been fabricated and irradiated. The purpose of testing LRO-37 was to determine if the low swelling afforded by a small titanium addition (as in ${ }^{1}$ LRO-35) could be 
repeated in a LRO alloy not containing sigma phase. The swelling behavior of both pairs of $(\mathrm{Fe}, \mathrm{Ni})_{3} \mathrm{~V}$ LRO alloys is compared with that of $20 \%-\mathrm{cold}-$ worked type 316 stainless steel, which was used as an internal standard.

\subsubsection{Experimental Procedure}

Specimens of LRO-20 and -37 were prepared the same as described in a previous report.1 The nominal compositions of these alloys, along with those for LRO-16 and -35 and the type 316 stainless steel standard, are given in Table 6.1.1. The carbon contents of most of the LRO alloys (Table 6.1.1) varied from about 100 to $200 \mathrm{wt} \mathrm{ppm}$. The specimens were irradiated and prepared for examination by transmission electron microscopy (TEM) as before. ${ }^{1}$ Cavity size distributions were determined on a Zeiss particle size analyzer, and swelling values were calculated from these distributions.

Table 6.1.1. The Long-Range-Ordered Alloy Compositions Compared with Type 316 Stainless Steel

\begin{tabular}{lcccccccc}
\hline & \multicolumn{8}{c}{ Content, wt \% } \\
\cline { 2 - 8 } & Fe & Ni & V & Ti & Cr & Mo & Mn & C \\
\hline LRO-16 & 46.1 & 31.0 & 23.0 & & & & & $a$ \\
LRO-35 & 45.3 & 31.8 & 22.6 & 0.4 & & & $a$ \\
LRO-20 & 37.6 & 39.5 & 22.9 & & & & $a$ \\
LR0-37 & 37.6 & 39.5 & 22.4 & 0.4 & & & & $a$ \\
D0316SS & Balance & 13 & & 0.005 & 18 & 2.0 & 1.9 & 0.05 \\
\hline
\end{tabular}

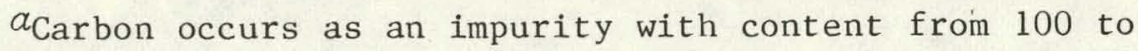
200 wt ppm.

\subsubsection{Results}

The microstructures of LRO-20 and -37 and $20 \%$-cold-worked type 316 stainless steel are compared before and after irradiation at $625^{\circ} \mathrm{C}$ in Figs. $6.1 .1,6.1 .2$, and 6.1 .3 , respectively. Before irradiation the 

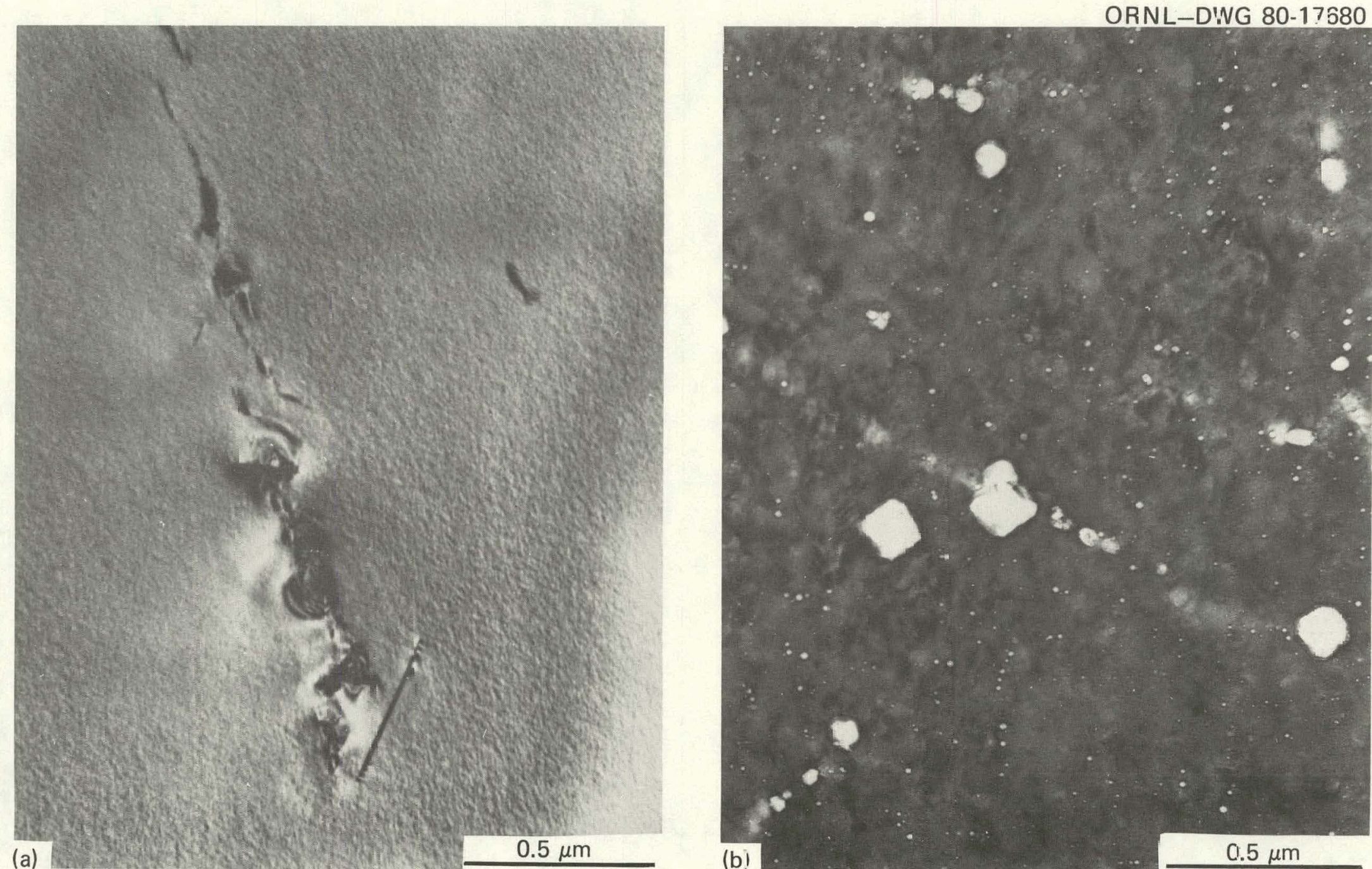

Fig. 6.1.1. Microstructure of LRO-20. (a) Before irradiation. (b) After irradiation with 4-MeV nickel ions at $625^{\circ} \mathrm{C}$ to $70 \mathrm{dpa}$, with simultaneous injection of 8 a. ppm He anc $2 \varepsilon$ at. ppm D per dpa. 

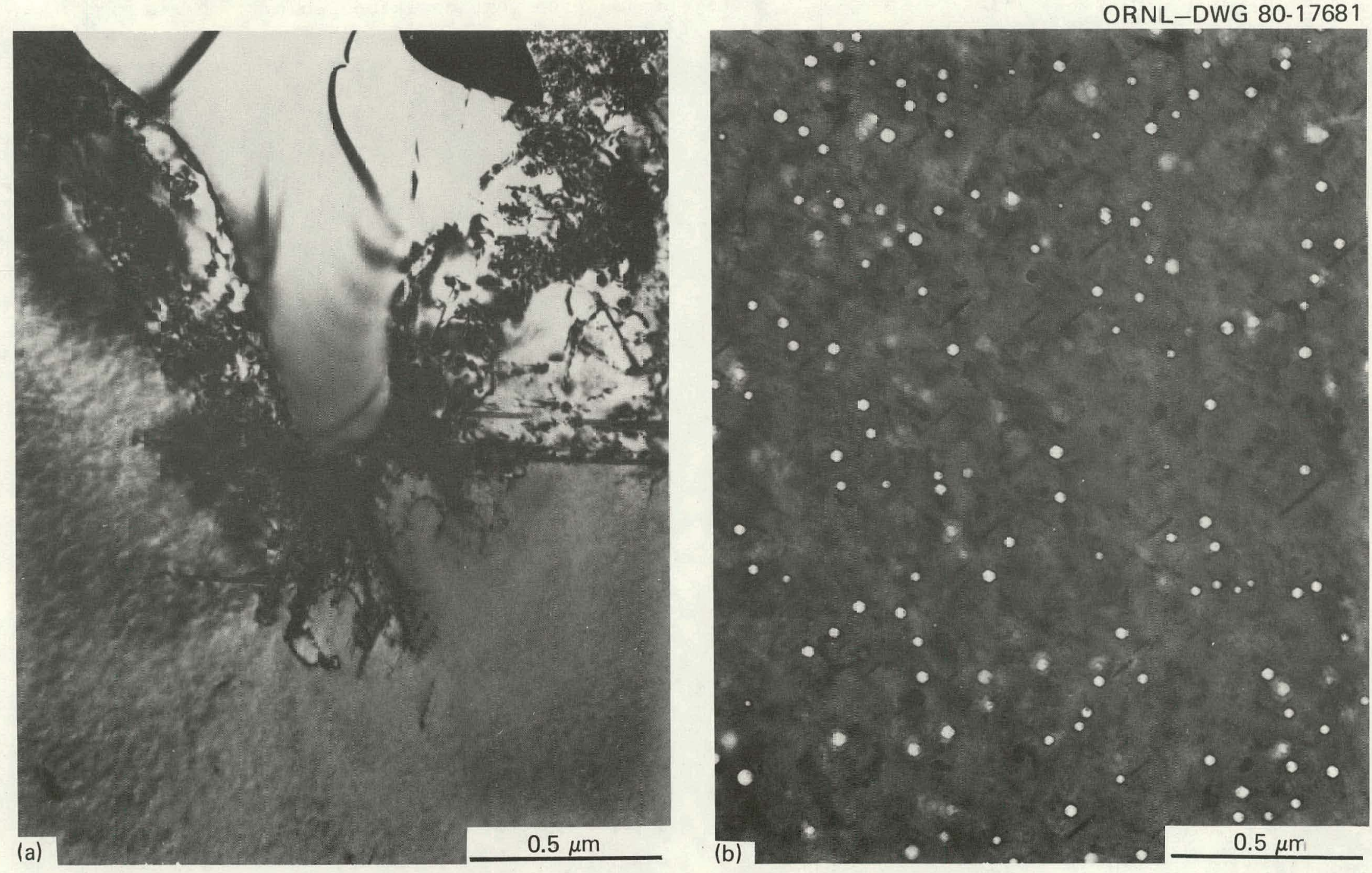

Fig. 6.1.2. Microstructure of LR0-37. (a) Before irradiat-on. (b) After irradiation with 4-MeV nickel ions at $525^{\circ} \mathrm{C}$ to $70 \mathrm{dpa}$, with simultaneous injection of 8 at. ppm He and 28 at. ppm D per dpa. 

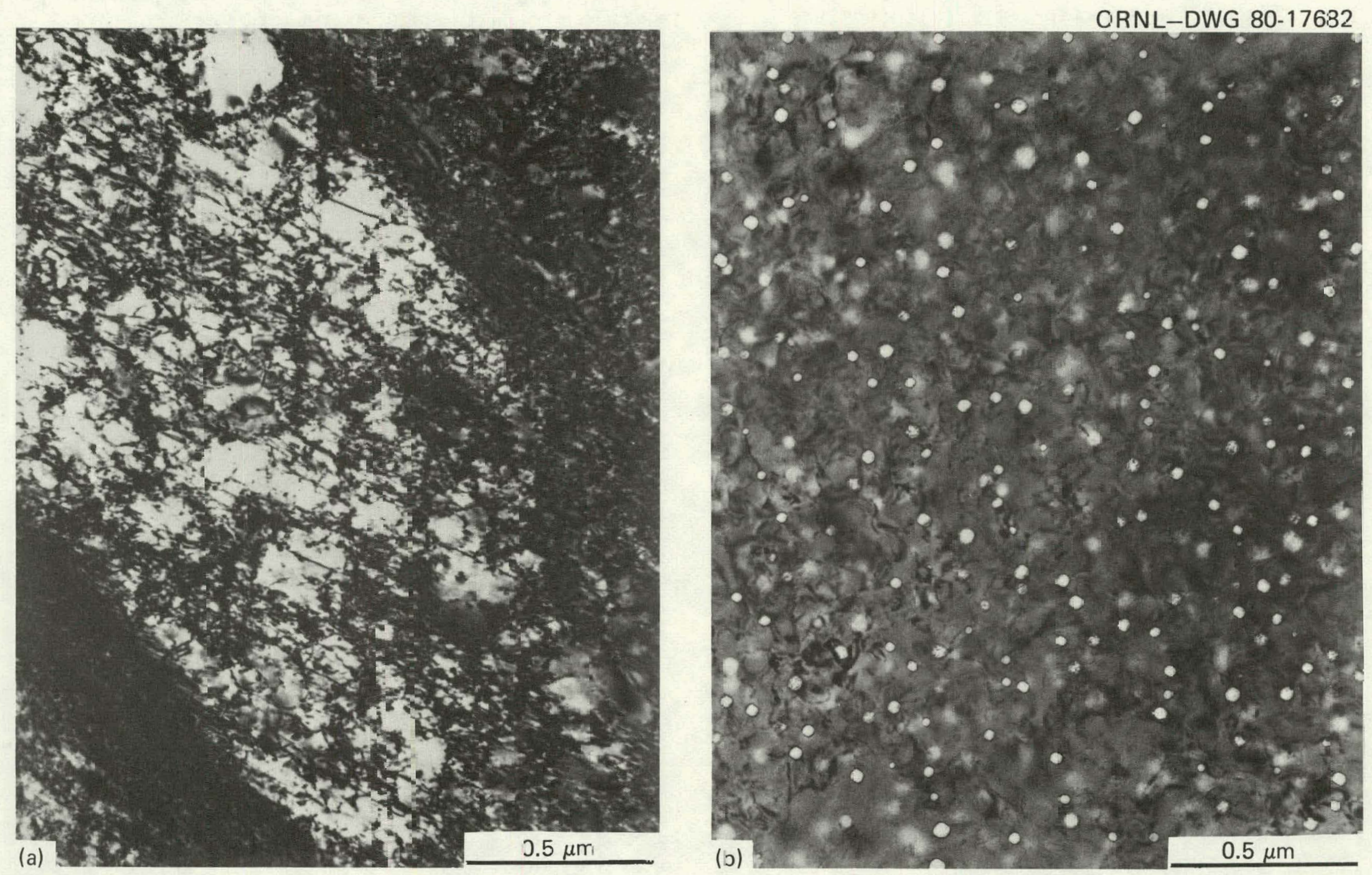

Fig. 6.1.3. Microstructure of 20\%-Cold-Worked Type 316 Stainless Steel. ( $)$ ) Before irradiation. (b) After irradiation with $L-\mathrm{MeV}$ nickel ions at $625^{\circ} \mathrm{C}$ to $70 \mathrm{dpa}$, with sinultaneous injection of 8 at. ppm He and 28 at. ppm I per dpa. 
microstructure of LRO-20 [Fig. 6.1.1(a)] contained only a few VC particles, which lie on isolated dislocation segments. The irradiation produced a bimodal cavity population and dislocation loops and segments [Fig. 6.1.1(b)]. Often the cavities were preferentially arranged in random "strings" or lines. The irradiated LRO-37 [Fig. 6.1.2(a)] contained a rather "clean" matrix with a very widely dispersed second phase that scanning transmission electron microscope (STEM) energy dispersive $x$-ray analysis showed to contain mostly $\mathrm{Ti}$ and smaller amounts of $\mathrm{V}, \mathrm{Fe}$, and $\mathrm{Ni}$. Complicated dislocation networks punched out from the second phase were decorated with small VC particles. Irradiation with 4-MeV nickel ions produced cavities [Fig. 6.1.2(b)] as well as dislocation loops and segments. The matrix remained free of any VC precipitate particles other than those surrounding the inclusions. The unirradiated $20 \%$-cold-worked type 316 stainless steel had a typical cold-worked microstructure, with dense dislocation tangles and deformation bands [Fig. 6.1.3(a)]. After irradiation at all elevated temperatures except $525^{\circ} \mathrm{C}$, the total dislocation density was lower than in the unirradiated material. At $525^{\circ} \mathrm{C}$ the dislocation density actually increased slightly. Figure 6.1.3(b) shows the type 316 stainless steel microstructure under kinematical diffraction conditions after irradiation at $625^{\circ} \mathrm{C}$. Under these conditions the cavities and only a few dislocations were imaged. The short dark lines oriented in the same direction are dislocation loops perpendicular to the plane of the specimen foil.

The swelling results for LRO-20 and -37 and those reported earlier ${ }^{1}$ for I.Rn-16 and -35 are shown in Fig. 6.1 .4 as a function of irradiation temperature. Data are also included for 20\%-cold-worked type 316 stainless steel, used as an internal standard. The type 316 scatter bars include data for that alloy from two separate irradiation runs and indicate the magnitude of scatter expected for the data on the LRO alloys. The measured swelling in all four of the LRO alloys was less than in the $20 \%$-coldworked type 31.6 stainless steel for irradiation temperatures below the critical ordering temperature, $T_{C}$, of about $670^{\circ} \mathrm{C}$. Above $T_{c}$ the LRO alloys were disordered or perhaps contained some short-range order, and all except LRO-35 swelled considerably more than the type 316. The swelling curves for these alloys (LRO-16, -20, and -37) were drawn to show a very 


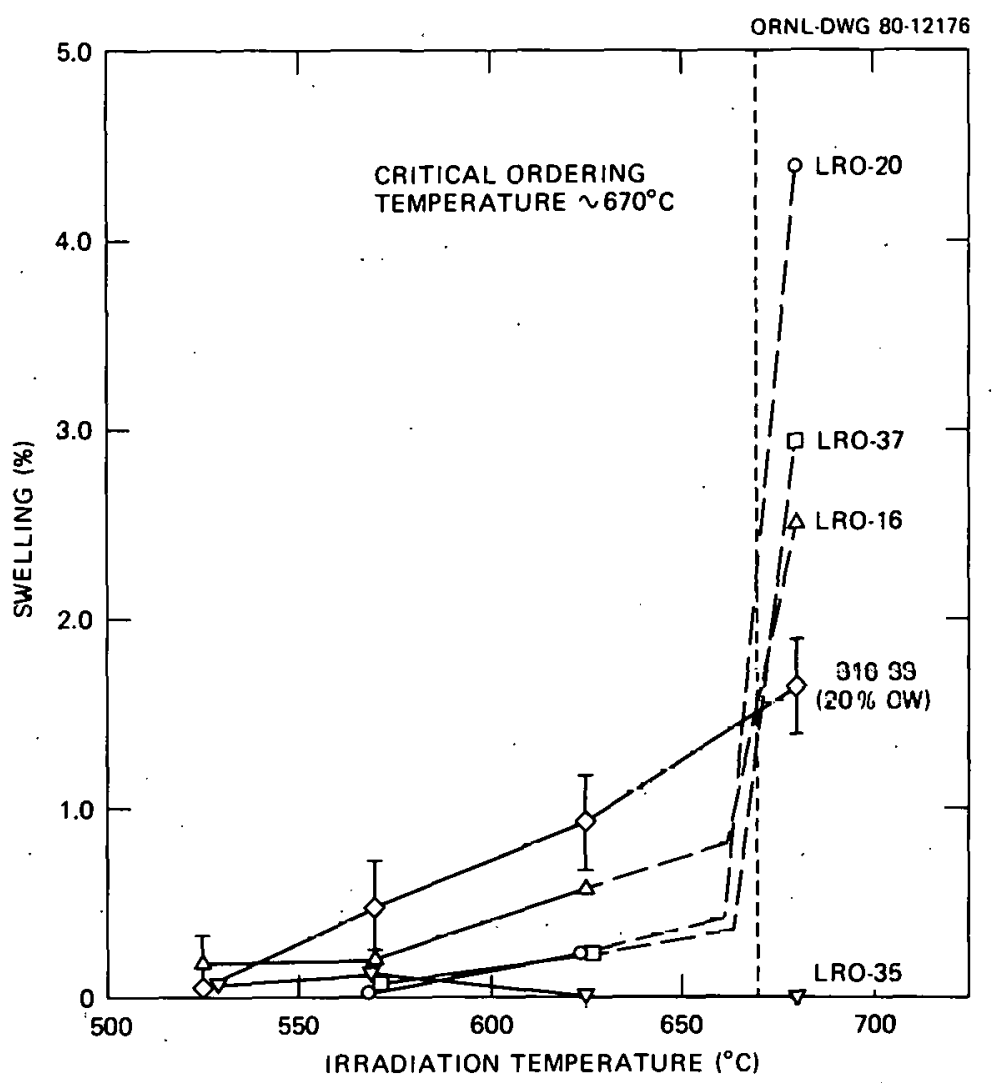

Fig. 6.1.4. Swelling of Iron-Base Long-Range-Ordered Alloys as a Function of Irradiation Temperature. Specimens were irradiated with 4-MeV nickel ions to $70 \mathrm{dpa}$, witli siluttaneuus lujecllon of 8 ar. ppim Hè and 20 at. jpm D pres dja.

rapid increase beginning just below $T_{0}$. This is a reasonable assumption; but the actual shape of the swelling curves in that temperature region has not been verified by experiment. On the basis of the swelling above $T_{C}$ observed for these three LRO alloys, the data for LRO- 35 at $680^{\circ} \mathrm{C}$ are suspect and should be reexamined. The effect of the titanium addition described previouslyl and shown in Fig. 6.1 .4 for the LRO-16 and -35 pair of alloys was not as striking for the LRO-20 and -37 pair, that is, the swelling behavior (bclow $T_{c}$ ) for Lllu-20 and -37 was nearly ideulical. Nevertheless, the effect of titanium in reducing swelling in LRO alloys deserves further investigation. The removal of sigma phase from the microstructure may have produced some resistance to swelling, as the LRO-20 alloy swelled less than LRO-16 for irradiation below $T_{c}$. However, the swelling of the two alloys was within the limits of scatter for one another. A definite conclusion concerning the effect. of sigma phase is not possible. 


\subsubsection{Conclusion and Future Work}

The iron-base LRO alloys investigated were more resistant to swelling than 20\%-cold-worked type 316 stainless steel when irradiated with 4-MeV nickel ions to $70 \mathrm{dpa}$ in the range 525 to $625^{\circ} \mathrm{C}$, with simultaneous injection of 8 at. ppm He and 28 at. ppm D per dpa. Small titanium additions appear to improve the resistance to swelling in some LRO alloys, but more work is needed to define its role in the process. The possible role of sigma phase in swelling of the LRO alloys has not been identified. A11 the LRO alloys retained their order as long as the irradiation temperature was kept below the critical ordering temperature of about $670^{\circ} \mathrm{C}$. Above $T_{C}$, the swelling in three of the four LRO alloys increased markedly to values greater than those observed for the type 316 .

Future work is aimed at determining the effect of ion irradiation as well as neutron irradiation in both the Oak Ridge Research Reactor (ORR) and lligh Flux Isotope Reactor (HFIR) on the microstructure and mechanical properties of the iron-base LRO alloys. The effects of adding different amounts of titanium to the. LRO alloys and using ferrovanadium melting stock on resistance to swelling will also be investigated. Finally, we will attempt to measure the degree of order quantitatively in the electron microscope. This technique will be used to examine any disordering that might occur because of irradiation.

\subsubsection{Reference}

1. D. N. Braski, "The Effect of 4-MeV Nickel Ion Irradiation on the Microstructure of ( $\mathrm{Fe}, \mathrm{Ni})_{3} \mathrm{~V}$ Long-Range-Ordered Alloys," ADIP Quart. Prog. Rep. June 30, 1980, DOE/ER-0045/3, pp. 162-73. 
122

Blank 
7. PATH E ALLOY DEVELOPMENT - FERRITIC STEELS 
7.1 CHARACTERIZATION OF FUSION-FERRITIC STEEL PROGRAI1 $12 \mathrm{Cr}$ HEAT AND METALLURGICAL STUDIES ON $12 \mathrm{Cr}-1$ Ho STEEL - R. D. Stevenson

(Ceneral Atomic Company)

No contribution this quarter. 
7.2 FRACTURE TOUGHNESS TESTING OF ALLOY HT-9 - J. R. Hawthorne (Naval Research Laboratory)

Lost in transit. 
7:3 ANALYSIS OF LASER WELDS IN HT9

J. C. Lippold (Sandia National Laboratories, Livermore, CA)

\subsubsection{ADIP Task}

The Department of Energy (DOE)/Office of Fusion Energy (OFE) has cited the need for these data under the ADIP Program Task, Ferritic Alloy Development (Path E).

\section{3 .2 objective}

Laser welding provides a low heat input, high energy density joining method which may be of value for welding the candidate $12 \mathrm{Cr}-1 \mathrm{Mo}$ ferritic/martensitic first wall alloy in the Experimental Test Facility (ETF). This phase of our investigation addressed the effect of weld variations on both the macroscopic weld quality and the microstructural features of HT9 laser welds. The laser welder employed is located at the Naval Research Laboratory, and was made available for this study through the courtesy of Dr. Ed Metzbower and Dr. Deug Moon.

\subsubsection{Summary}

Laser welds were made in $6.35 \mathrm{~mm}$ (0.25 in) HT9 plate using a variety of travel speed/focal length combinations at a constant laser power level of $6 \mathrm{~kW}$. Welde performed at oharp focus with weld travel speeds ranging from 1.27 to $4.23 \mathrm{~mm} / \mathrm{sec}$ exhibited scattered porosity and occasional centerline cracking. Defocusing the laser beam relative to the plate resulted in welds containing severe porosity and contcrline cracks. Microstructural and microhardness evaluation of the welds indicated that the region of highest hardness occurred in the heat-affected zone immediately adjacent to the fusion line. A mechanism for centerline cracking in this alloy has been proposed.

\subsubsection{Progress and Status}

High energy density, low heat input welding processes are often employed to join materials which are susceptible to cracking in the heataffected zone (HAZ) or which experience a degradation in mechanical 
properties as a result of the weld thermal cycle. The steep thermal gradient which is established in the HAZ of laser welds minimizes the extent of the susceptible microstructure and reduces the thermallyinduced distortion associațed with other fusion welding processes.

The formation of untempered martensite in the fusion zone and HAZ of HT9 weldments presents a serious fabrication problem which normally must be alleviated by postweld heat treatment. Laser welding of HT9 will minimize the amount of untempered martensite which forms and hopefully produce a microstructure which is more amenable to postweld heat treatment.

\subsubsection{Experimental Approach}

The HT9 base material was provided by General Atomics Company in the form of $12.7 \mathrm{~cm}$ (5 in) 0.D. pipe with a $6.4 \mathrm{~mm}(0.25 \mathrm{in})$ wall thickness. The composition of the material is listed in l'able 1 . Sections $5.08 \mathrm{~cm}$ (2 in) wide were removed from the pipe parallel to the longitudinal axis. These sections were subsequently rolled flat, austenitized for 30 minutes at $1150^{\circ} \mathrm{C}\left(2100^{\circ} \mathrm{F}\right)$, and tempered for 1 hour at $750^{\circ} \mathrm{C}\left(1380^{\circ} \mathrm{F}\right)$. The resultant microstructure consisted of a mixture of tempered martensite and carbides and exhibited a hardness of $R_{c} 22$.

Table 1

Chemical Composition (wt\%)

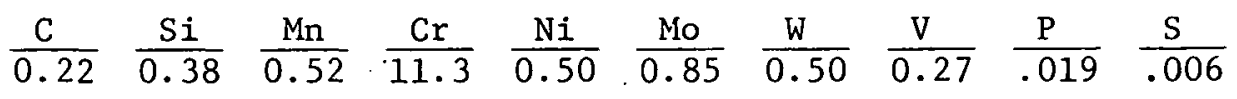

Autogenous, bead-on-plate laser welds were made at the Naval Research Laboratory using a continuous wave $\mathrm{CO}_{2}$ laser rated at $15 \mathrm{~kW}$ maximum output. The experimental program investigated the effect of travel speed and weld heat input on weld quality when the laser beam was focused on the surface of the workpiece (sharp focus). In addition, the effect of focal distance on both weld quality and weld penetration was evaluated. All welds were made without preheat and subsequent evaluation was performed on samples in the as-welded condition. The weld parameters and resultant weld appearance are outlined in Table 2. Weld defects, 
including both cracks and porosity, were located by $x$-ray radiography. Metallographic sections transverse to the welding direction were examined to determine the nature of. the weld defects and to reveal the microstructural details of the weld region.

Table 2

Laser Weld Parameters

\begin{tabular}{|c|c|c|c|c|c|c|}
\hline Weld \# & $\begin{array}{l}\text { Travel Speed } \\
\mathrm{mm} / \mathrm{sec} \text { (in/min) }\end{array}$ & $\begin{array}{l}\text { Focal Distance } \\
\mathrm{cm} \text { (in) }\end{array}$ & $\begin{array}{l}\text { Heat } \\
\mathrm{kJ} / \mathrm{mm}\end{array}$ & $\begin{array}{l}\text { [nput } \\
(\mathrm{kJ} / \mathrm{in})\end{array}$ & Defects & \\
\hline II-1 & $1.27(30)$ & & 0.47 & (12) & None & \\
\hline I. I-3 & $1.69(40)$ & & 0.35 & $(9)$ & Parosity & \\
\hline$I-2$ & $2.12(50)$ & & 0.28 & $(7.2)$ & $\begin{array}{l}\text { Porosity } \\
\text { Cracking }\end{array}$ & \\
\hline$I-3$ & $2.33(55)$ & $51.44(20.25)$ & 0.26 & $(6.55)$ & $\begin{array}{l}\text { Porosity } \\
\text { Cracking }\end{array}$ & \\
\hline$I-4$ & $2.96(70)$ & & 0.20 & $(5.14)$ & Porosity & (severe) \\
\hline$I I-5$ & $3.39(80)$ & & 0.18 & $(4.5)$ & $\begin{array}{l}\text { Cracking } \\
\text { Porosity }\end{array}$ & \\
\hline I T -6 & 3.81. (90) & & 0.16 & (4) & Porosity & \\
\hline $\mathrm{II}-7$ & $4.23(100)$ & & 0.14 & $(3.6)$ & Porosity & \\
\hline$I-9$ & & $51.69(20.35)$ & & r & $\begin{array}{l}\text { Porusity } \\
\text { Cracking }\end{array}$ & \\
\hline $\mathrm{I}-10$ & & $51.94 \quad(20.45)$ & & & Porosity & \\
\hline$I-11$ & $2.96(70)$ & $52.20(20.55)$ & 0.20 & $(5.14)$ & Porosity & \\
\hline $\mathrm{I}-12$ & & $51.18(20.15)$ & & & Porosity & (severe) \\
\hline$I \cdot 13$ & & $50.93(20.05)$ & & $\cdot$ & Porosity & \\
\hline$T-14$ & & 50.67 (29.9) & & & $\begin{array}{l}\text { Purusity } \\
\text { Cracking }\end{array}$ & (severe) \\
\hline
\end{tabular}

\subsubsection{Effect of Weld Travel Speed}

The effect of weld travel speed on the penetration characteristics and weld bead contour is illustrated by the series of macrographs in Figure 1. All the welds were made at a laser power-level of $6 \mathrm{~kW}$ and sharp focus. Since the weld heat input is inversely proportional to the travel speed, the heat input decreases as the welding speed increases, so that increased speed results in welds with progressively less pene- 


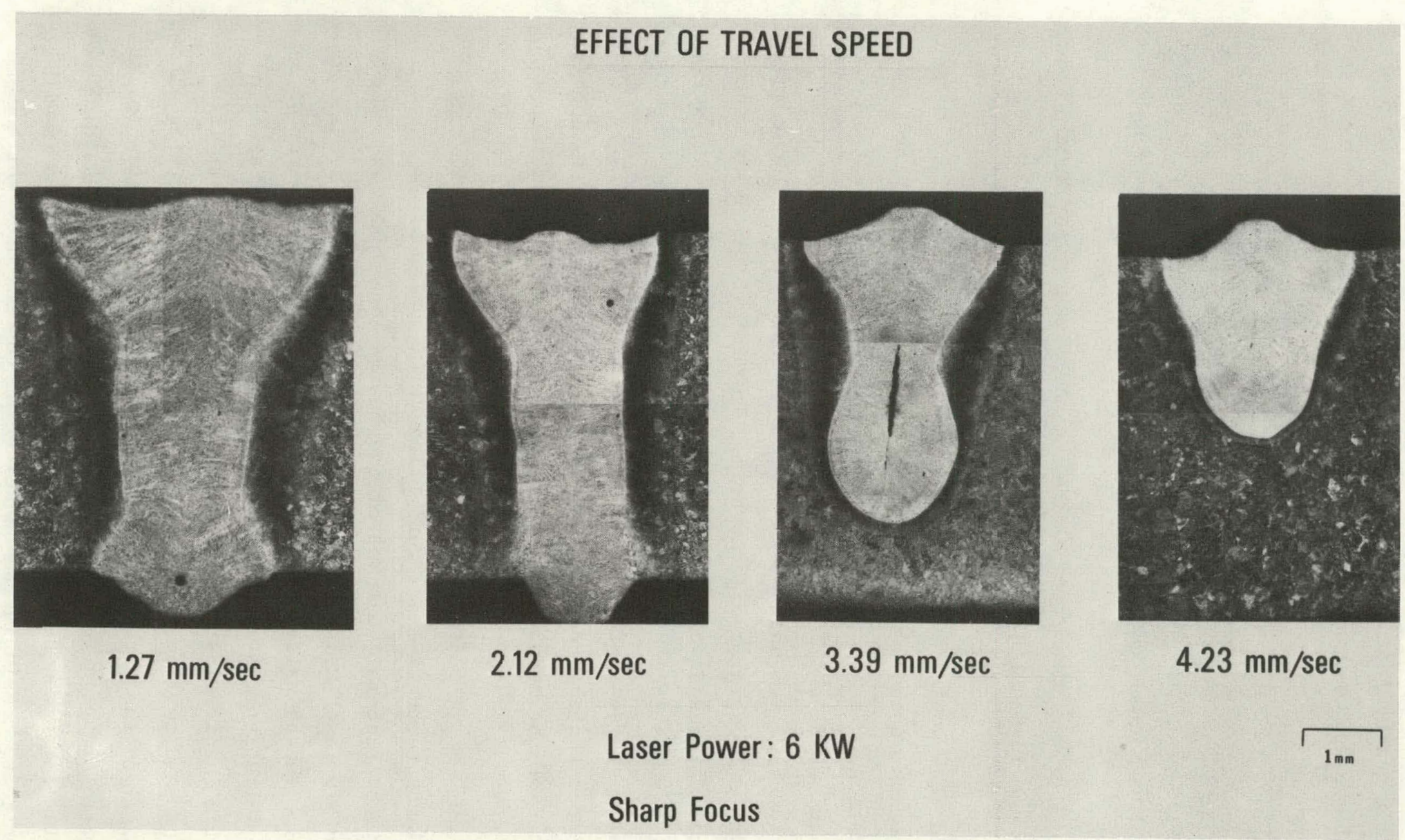

Figure 1. The Effect of Weld Travel Speed on Penetration and Weld Quality of HT9 Laser Welds. 
tration. Radiography indicated that some degree of porosity was associated with all the welds except for the highest heat input weld made at $1.27 \mathrm{~mm} / \mathrm{sec}$.

Centerline cracking was observed sporadically in a majority of the welds and was generally discontinuous along the weld length. Although no direct correlation could be found between the incidence of cracking and travel speed, welds with high aspect ratios appeared to be more susceptible.

\subsubsection{Effect of Focal Distance}

The effect of the laser focal length relative to sharp focus was investigated at a power level of $6 \mathrm{~kW}$ and a travel speed of $2.96 \mathrm{~mm} / \mathrm{sec}$. These parameters at sharp focus were the minimum required to achieve full penetration. The focal length ranged from $7.7 \mathrm{~mm}$ above the workpiece surface (overfocus) through sharp focus to $7.7 \mathrm{~mm}$ below the surface (underfocus). The series of macrographs in Figure 2 illustrates the effect of defocusing the laser beam. In genera1, porosity was observed in all defocused welds and became particularly severe in welds where the laser was focused above the plate surface. Varying the focal length relative to sharp focus also reduced the weld penetration. The infrequent occurrence of centerline cracking in these welds is probably a consequence of the reduced aspecl raliu which results from defocusing the laser beam.

\subsubsection{Microstructural Characterization}

The microstructural features of the fusion zone, HAZ, and base metal of an HT9 laser weld made at sharp focus and $2.96 \mathrm{~mm} / \mathrm{sec}$ are shown in Figure 3. The as-welded fusion zone microstructure consists of a mixture of delta ferrite and untempered martensite. The metastable ferrite which is distributed along the boundaries of the solidification substructure results from the segregation of ferrite stabilizing elements ( $\mathrm{Cr}$, Mo, W, V) to these regions during solidification. Rapid cooling from the solidification range inhibits the diffusion-controlled, solld state ferrite-to-austenite transformation and permits a large proportion of the ferrite to remain in the as-welded microstructure. Although the 


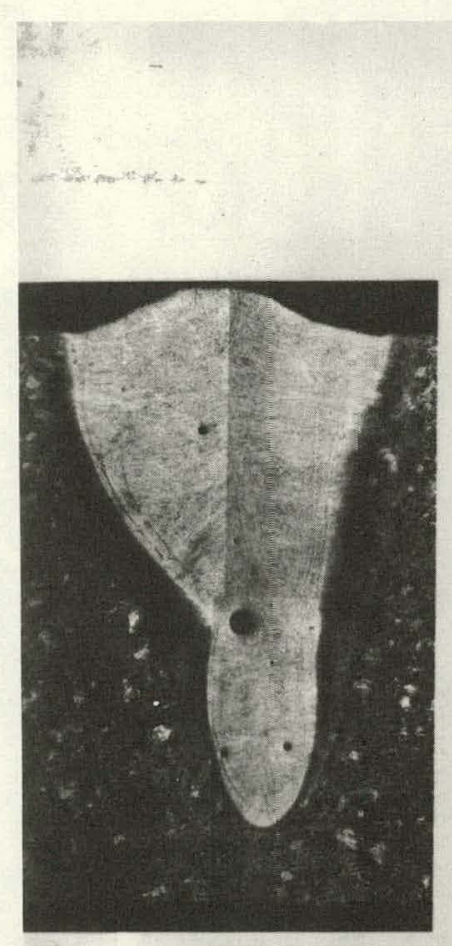

$-7.5 \mathrm{~mm}$

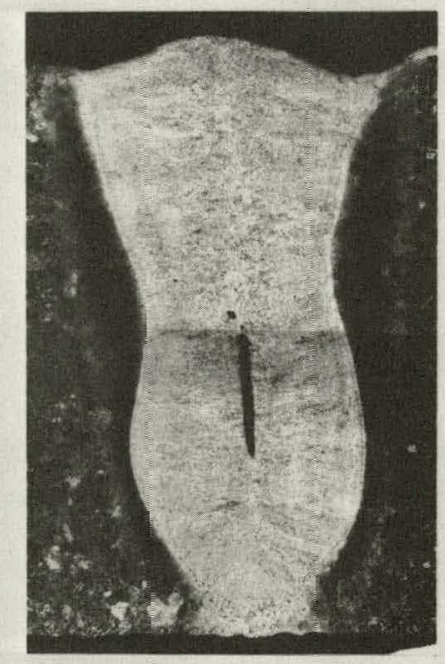

$-2.5 \mathrm{~mm}$, underfocus

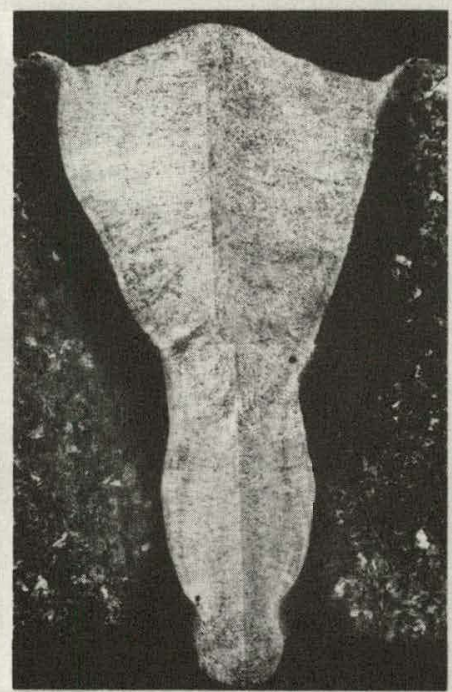

Sharp Focus

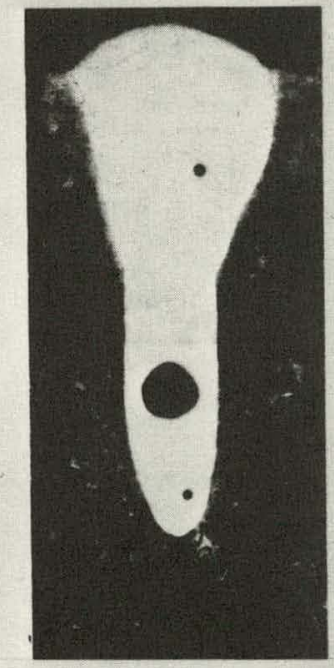

$2.5 \mathrm{~mm}$, overfocus

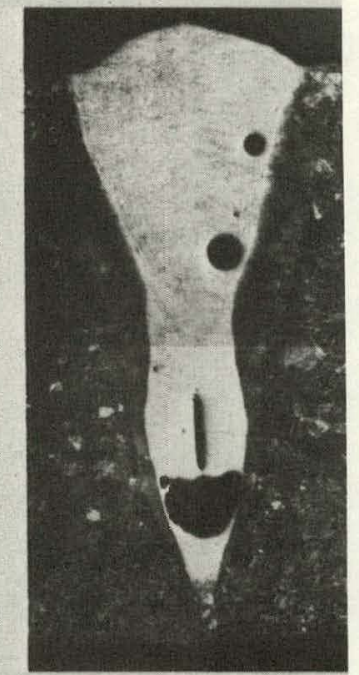

$7.5 \mathrm{~mm}$

Laser Power : $6 \mathrm{KW}$

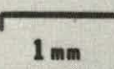

Travel Speed: $2.96 \mathrm{~mm} / \mathrm{sec}$

Figure 2. The Effect of Focal Distance on the Weld Quality of HT9 Laser Welds. 
amount of retained ferrite is a function of both the solute segregation associated with solidification and the weld cooling rate, it appears that the cooling rate is more influential in controlling the microstructure. The small proportion of residual ferrite observed in gas-tungsten arc (GTA) welds in the same material tends to support this observation. ${ }^{1}$ The microstructure along the fusion boundary in Figure 3 consists almost entirely of untempered martensite. Occasional islands of ferrite are observed along prior austenite grain boundaries; these islands result from the solid-state transformation of austenite to ferrite at temperatures slightly below the bulk solldus Lempesalure. The rapid thermal excursions associated with low heat input laser welds prevent the more extensive transformation to ferrite which was observed in the fusion boundary region of GTA welds.

The HAZ consists of two distinct microstructural regions. The first region, immediately adjacent to the fusion line consists entirely of untempered martensite and extends less than $0.25 \mathrm{~mm}$ from the fusion line. This region represents the portion of the HAZ in which the martensite has completely transformed to austenite and the alloy carbides have been resolutionized. The fine lath-like morphology of this region is shown in f'ıgure 3. Wore rellule flum the fusion linc the microstructure evolves into a mixture of untempered martensite and carbides. The lower austenization temperature experienced by this region prevents complete dissolution of the carbides and lowers the as-welded hardness relative to the fully transformed HAZ. Evidence of the alloy carbides interspersed among the martensite laths can also be seen in Figure 3.

\subsubsection{Effect of Cooling Rate on As-Welded Hardness}

Microhardness indentations were made within both the fusion zone and $\mathrm{HAZ}$ of a series of laser welds of varying heat input in order lo determine the effect of cooling rate on the as-welded hardness. 'l'he maximum hardness observed in each region is summarized in Table 3. Hardness data from a previous investigation of GTA welds are also included for comparison. 


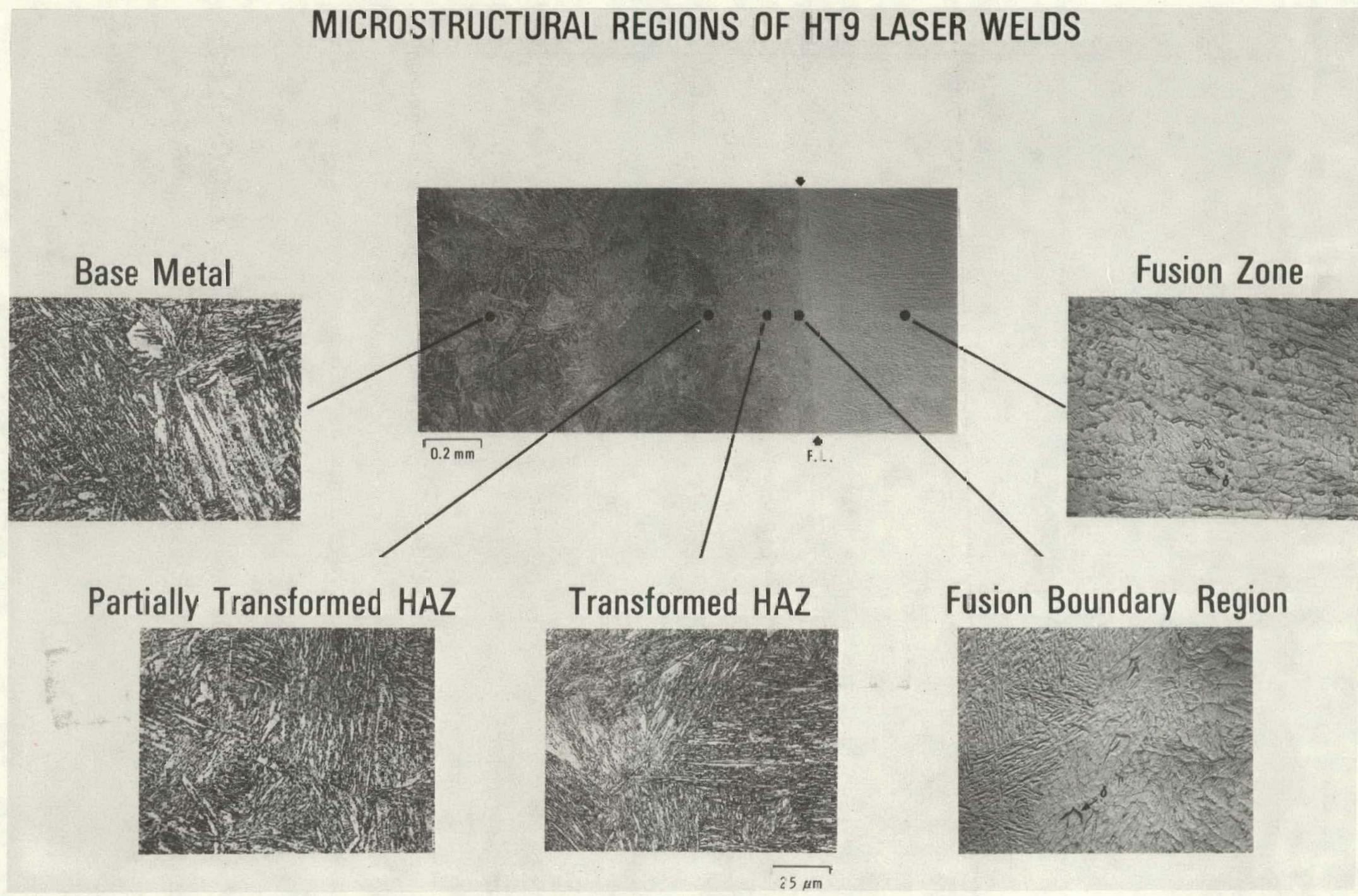

Figure 3. Representative Microstructure of the Weld Regions and Base Metal in HT9 Laser Welds. Note the Retained Ferrite (arrows) in both the Fusion Zone and Fusion Boundary Region. 
Table 3

Hardness of Weld Regions

\begin{tabular}{lccc} 
Weld 非 & $\begin{array}{c}\text { Heat Input } \\
(\mathrm{kJ} / \mathrm{mm})\end{array}$ & $\begin{array}{c}\text { Fusion Zone } \\
\left(\mathrm{R}_{\mathrm{c}}\right)\end{array}$ & $\begin{array}{c}\mathrm{HAZ} \\
\left(\mathrm{R}_{\mathrm{c}}\right)\end{array}$ \\
\hline II-1 & 0.47 & 46 & 48.5 \\
I-3 & 0.26 & 49 & 51 \\
II-7 & 0.14 & 52 & 53 \\
GTA & 0.79 & 49 & 49
\end{tabular}

The hardness of the fully transformed HAZ always slightly exceeds the hardness of the fusion zone, probably as a consequence of the twophase mixture of untempered martensite and ferrite in the fusion zone. The increase in hardness with decreasing heat input indicates that the martensite hardness is somewhat sensitive to cooling rate. This effect probably results from the formation of extremely fine martensite laths upon rapid cooling, augmented by the suppression of autotempering since the structure is effectively quenched from the austenization temperature.

\subsubsection{Temperature Gradients in the HAZ}

The results of microhardness traverses from the fusion line into the HA7 can be used to calculate the approximate temperature gradient which is established during laser welding. The hardness of the HAZ results from heating into the temperature range between the lower critical temperature $\left(A_{C_{1}}\right)$ and the solidus temperature, followed by subsequent cooling to produce untempered martenite. Departure from base melal hardness therefore indicates that the region has experienced a temperaturc above the $A_{c_{1}}$. Measurement of the extent of this region allows one lo calculate the local temperature gradient $(\mathrm{C} / \mathrm{mm})$ assuming that the solidus temperature is appluximately $1400^{\circ} \mathrm{C}$ and the $A_{C_{\perp}}$ is $850^{\circ} \mathrm{C}$. The resulting temperature gradients estimated for laser welds of varying heat inputs and also in a reference GTA weld are listed in Table 4. 
Table 4

Estimated Temperature Gradients in the HAZ

\begin{tabular}{lcc} 
Weld \# & Heat Input & Gradient $(\mathrm{C} / \mathrm{mm})$ \\
\hline II-1 & 0.47 & 430 \\
I-3 & 0.26 & 720 \\
II-7 & 0.14 & 1450 \\
GTA & 0.79 & 270
\end{tabular}

The steepness of the gradients generated during laser welding result in narrower heat-affected zones than in GTA welds which produce the same penetration. As a consequence the extent of the region adjacent to the fusion line which exhibits full martensitic hardness will be drastically reduced in low heat input laser welds. Minimization of this region may be an important factor when considering the tempering response and subsequent mechanical properties of the weld region.

\subsubsection{Centerline Cracking Mechanism}

Cracking was frequently observed along the centerline of high aspect ratio welds. The rapid travel speeds employed in laser welding produce an elongated, teardrop-shaped weld puddle which in turn leads to impingement of advancing solidification fronts along a distinct line midway between the opposing fusion lines. This impingement is accompanied by localized enrichment of the centerline region in solute elements pushed ahead of the solidification front. This localized enrichment along a plane transverse to the direction of maximum thermally-induced stress tends to lower the local solidus temperature, thereby creating a cracksusceptible microstructure.

The microstructure in the vicinity of a centerline crack is shown in Figure 4. At higher magnification it can be seen that the crack is associated with islands of ferrite (as denoted by the arrows) which run along the centerline. Again, this ferrite results from solute redistribution during solidification and its location corresponds to regions which were the last to solidify. It has been proposed ${ }^{2}$ that cracking along the centerline is not associated with the solidification process; instead, 


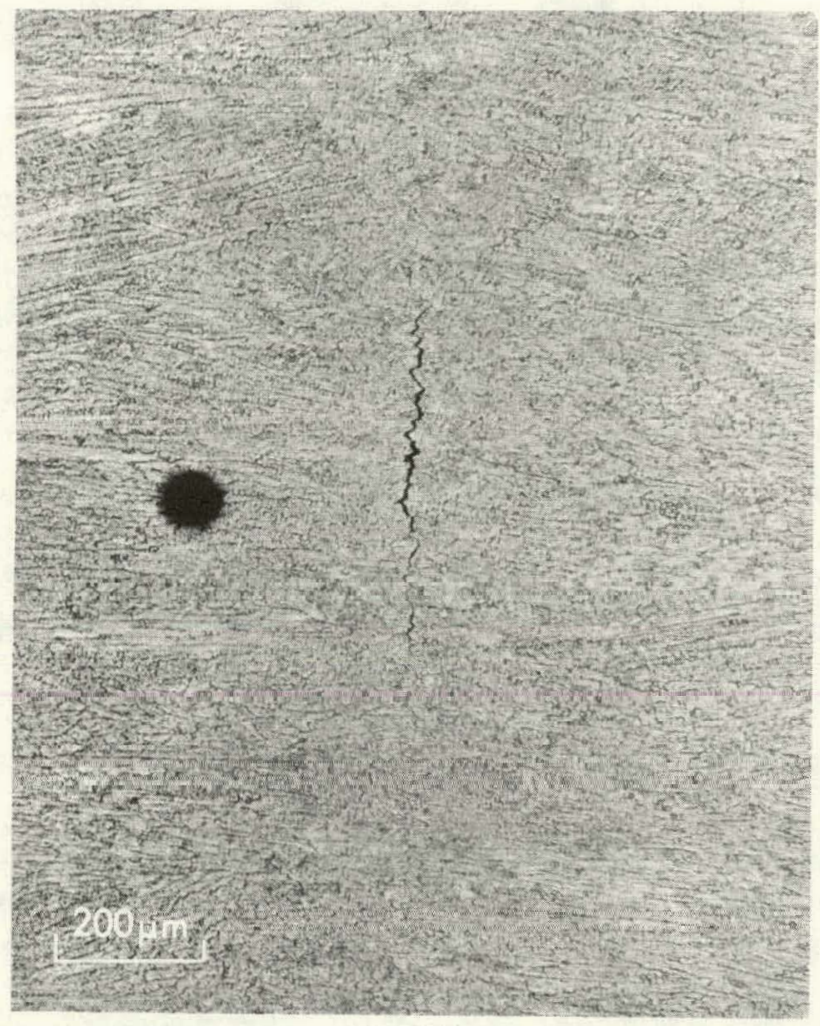

(a)

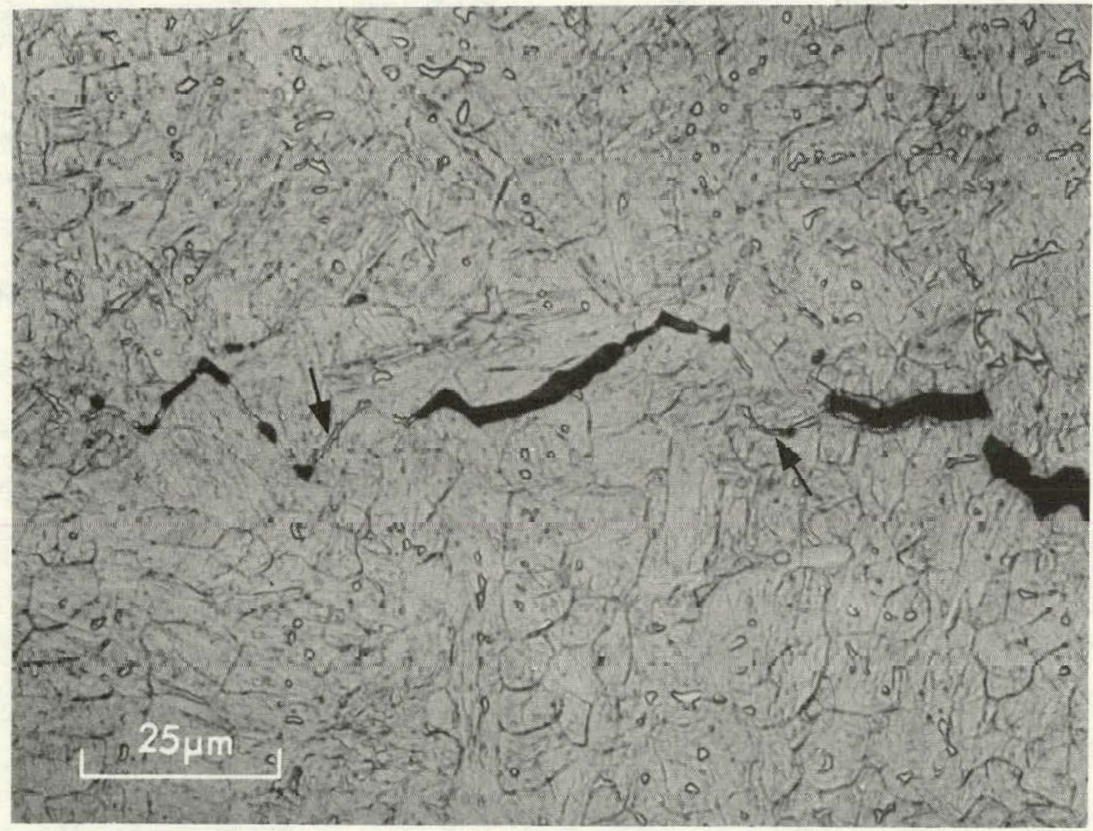

(b)

Figure 4. Cracking Along the Weld Centerline, a) $75 \mathrm{X}$; b) $800 \mathrm{x}$. Arrows denote retained ferrite associated with the fracture path. 
cracks form in the solid state due to the lower strength of the delta ferrite relative to the untempered martensite.

Sections of the weld containing the centerline crack surface were examined in the scanning electron microscope (SEM) in order to determine the failure mechanism. A fractograph of the crack surface is shown in Figure 5. The dendritic morphology of the surface reflects the solidification substructure of the fusion zone and indicates that failure occurred during the final stages of solidification. Since a solid-state fracture through the ferrite would most likely produce a ductile dimple fracture morphology, it is apparent that local depression of the solidus temperature along the weld centerline produces the crack-susceptible microstructure responsible for the centerline cracks.

\subsubsection{Conclusions}

1. Radiographic and metallographic examination of HT9 laser welds revealed the presence of both porosity and centerline hot cracks in the majority of the welds.

2. Increasing the weld travel speed at sharp focus decreased the weld penetration and resulted in little deterioration of the weld quality.

3. Defocusing the laser beam relative to the surface of the workpiece was the most deleterious variable affecting weld quality.

4. The retention of metastable delta ferrite in the weld fusion zone results from the suppression of the diffusion-controlled ferrite-toaustenite transformation upon rapid cooling from the solidification range.

5. The hardness of the fully transformed region of the heat-affected zone was found to be sensitive to the rate of cooling from the austenitizing temperature range.

6. Cracking along the weld centerline results from the localized depression of the solidus temperature concurrent with the final stages of solidification. 


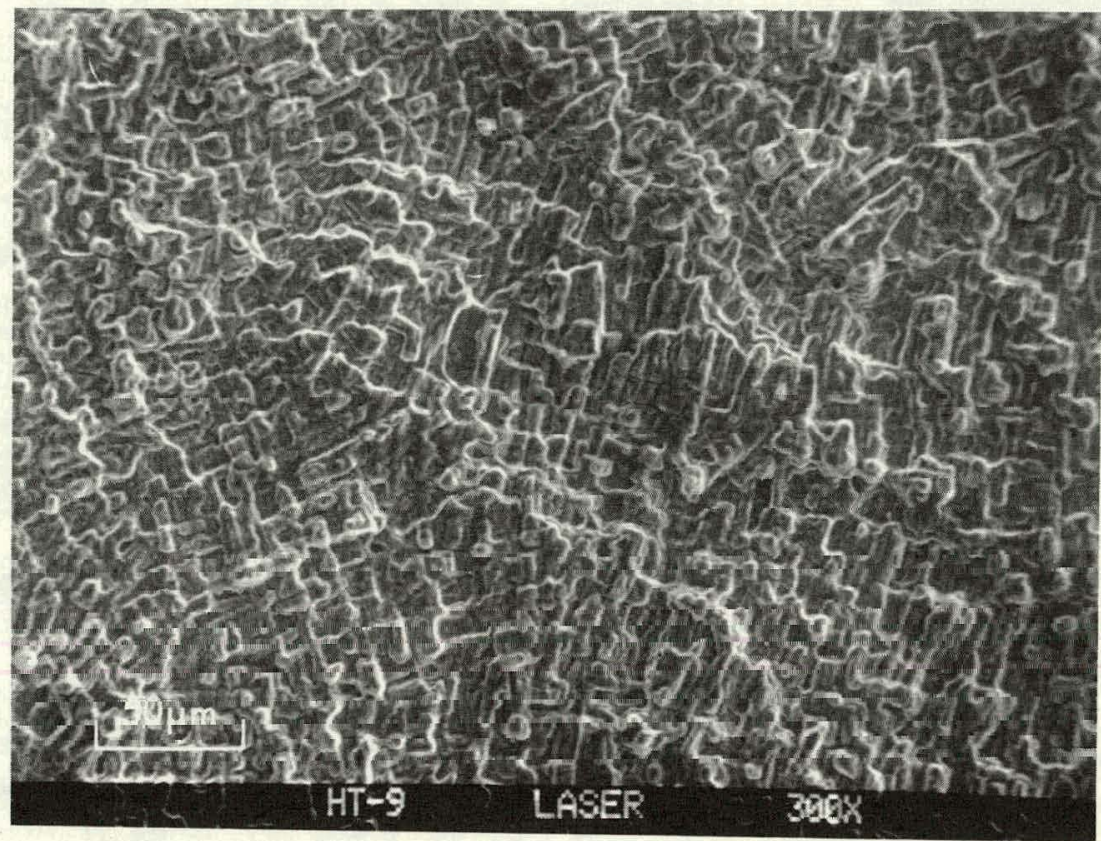

(a)

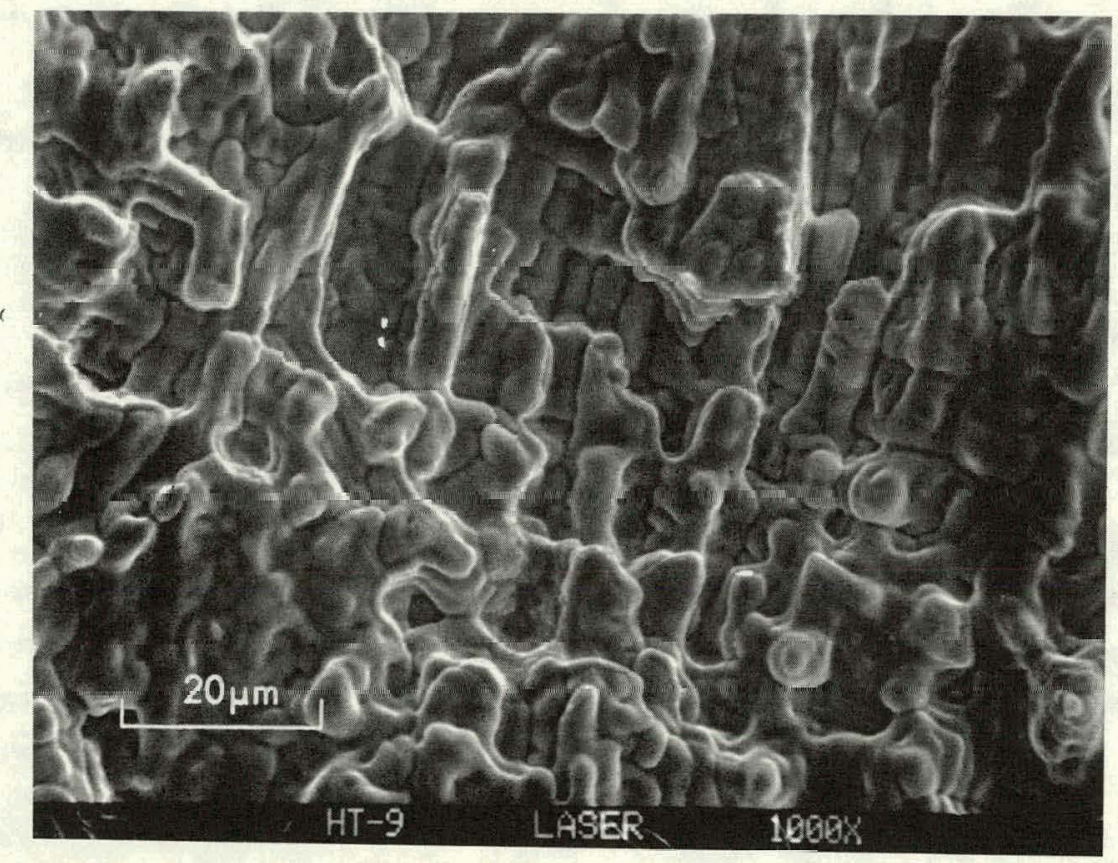

(b)

Figure 5. SFM frartngraphs of the centerline crack surface; a) 300X; b) $1000 \mathrm{X}$. 


\subsubsection{References}

1. Lippold, J. C., "Weldability of HT9: The Autogenous GTA Process", ADIP Quarterly Progress Report for period ending March 31, 1980, pp. 98-108.

2. Fidler, R. S., and Gooch, D. J., "The Hot Tensile Properties of Simulated Heat Affected Zone Structures in 9 CrMo and 12 CrMoV Steels", Ferritic Steels for Fast Reactor Steam Generators, Vol. 1, British Nuclear Energy Society (1978), p. 135. 
7.4 ENVIRONMENTAL EFFECTS ON PROPERTIES OF FERRITIC STEELS - O. K. Chopra and D. L. Smith (Argonne National Laboratory)

7.4.1 ADIP Task

ADIP tasks are not defined for ferritic steels in the 1978

program plan.

\section{4 .2 Objective}

The objective of this program is to investigate the compatibility, corrosion, and influence of chemical environment on the mechaniral properties of ferritic steels under conditions of interest in fusion reartnrs. 'l'est enviromments to be investigated include lithium, water, and helium as well as candidate solid breeding materials and neutron multipliers. Emphasis will be placed on the combined effect of stress and chemical environment on corrosion and mechanical properties of ferritic steels. Tests have been formulated to determine the (1) effect of liquid Iithium environment on fatigue and creep-fatigue properties of ferritic steels and (2) compatibility of structural materials with liquid lithium and candidate solid tritium-breeding materials. Initial tests will focus on the Sandvik Alloy HT-9 and a developmenta1 Fe-9r.r-1Mo staol.

\section{4 .3 Summary}

Several continuous-cycle fatigue tests have been conducted with 2.5-mm-diameter specimens of HT-9 alloy at $755 \mathrm{~K}$ in flowing 1ithium. The results indicate a strong effect of corrosion on the fatigue life of HT-9 alloy in a liquid lithium environment. At a total strain range of $0.5 \%$, the fatiguc life in lithium is a factur of $\sim 5$ lower than that in a liquid sodium environment. The specimens tested in lithium show intergranular cracks along the entire gauge length. Fatigue tests at different sLraln races and strain sequence are being conducted to establish the important parameters, viz., stress/strain range, frequency, lithium purity, etc. Exposure of corrosion specimens of HT-9 alloy, Type 316 stainless steel, and Inconel 625 with solid $\mathrm{Li}_{2} \mathrm{O}, \mathrm{LiAlO}_{2}$, and $\mathrm{Li}_{2} \mathrm{SiO}_{3}$ breeding materials at $873 \mathrm{~K}$ has been completed. Metallographic evaluation of the specimens is in progress. Preliminary results indicate that lithium oxide is the most reactive of the three breeding materials. 


\subsubsection{Progress and Status}

\subsubsection{Introduction}

Ferritic steels, such as Sandvik HT-9 and developmental Fe-9Cr-1Mo, have been proposed as candidate materials for the first wal1/blanket of magnetically confined fusion reactors. The primary incentive for consideration of ferritic steels is their lower void swelling behavior and higher in-reactor creep resistance than austenitic stainless steels. Also, the better physical properties provide a reduced thermal stress factor. However, relatively little information is available on the influence of the chemical environment on mechantcal properties of ferritic steels.

The first wall undergoes the most severe thermal cycling because of its exposure to the plasma. Consequently, the fatigue behavior of the material is an important consideration in the design of the first wall/blanket region. The initial phase of the present program is designed to provide data on the (1) effects of a liquid lithium environment on the fatigue properties of $\mathrm{HT}-9$ and $\mathrm{Fe}-9 \mathrm{Cr}-1 \mathrm{Mo}$ steels and (2) compatibility of candidate ferritic steels with liquid lithium and solid tritium-breeding materials.

\subsubsection{Fatigue Tests}

The facility for conducting fatigue tests in a flowing lithium environment has been described in an earlier report. ${ }^{1}$ The system consists of a servocontrolled, hydraulic-actuated MTS fatigue machine with an associated forced-flow liquid lithium 1oop. The 11thlum luop, which is constructed of stainless steel, consists of three test vessels and a cold-trap purification system. The lithium loop was operated continuously at cold-trap temperatures between 475 and $500 \mathrm{~K}$ and maximum temperatures between 620 and $760 \mathrm{~K}$. After $\sim 10.8 \mathrm{Ms}(\sim 3000 \mathrm{~h}$ ) of operation, the cold-trap purification loop showed a gradual reduction in lithium flow. Eventually, the loop was shut down after 215.1 Ms (4200 h) due to plugging of the cold-trap loop. The flowmeter and pump section of the cold-trap loop were cut out and replaced by a new pipe. The deposits in the plugged section are being examined metallographically to determine the nature and composition of the deposits. 
During operation, filtered lithium dip samples were taken after fixed time intervals for analysis of nitrogen and carbon in lithium. Specimens of zirconium, vanadium, and yttrium were exposed to lithium to determine the concentrations of oxygen and hydrogen in lithium. The concentrations of nitrogen and carbon in lithium obtained after different loop operating time are given in Table 7.4.1. The results indicate that after $210.8 \mathrm{Ms}$ of loop operation, the concentration of nitrogen in lithium was $>1000 \mathrm{ppm}$.

Several continuous-cycle fatigue tests have been conducted with 2.5-mm-diameter specimens of HT-9 alloy in flowing lithium at $755 \mathrm{~K}$. The tests were conducted in the axial stroke-control mode at a strain rate of $44 \times 10^{-3} \mathrm{~s}^{-1}$, with a fully reversed triangular waveform and zero mean strain. The dinensions of the test specimens and the procedure fui slidil control and strain measurement were described earlier.2,3 The fatigue specimens were normalized at $1323 \mathrm{~K}$ for $1.8 \mathrm{ks}$ and air cooled followed by tempering at $1053 \mathrm{~K}$ for $9.0 \mathrm{ks}$ and air cooled.

The continuous-cycle fatigue data for HT-9 alloy tested at $755 \mathrm{~K}$ in lithium and sodium environments are shown in Fig. 7.4.1. The results show that in a lithium environment, the plastic strain range and fatigue life follow a single power-law relationship up to $\sim 25,000$ cycles. Fatigue life beyond 25,000 cycles is significantly lower than that predicted by the power law. Fatigue results for the sperimens tested in a sodium environment agree well with the power-law relationship. These results indicate a strong effect of corrosion on the fatigue life of HT-9 alloy in a liquid lithium environment. For example, at a tntal strain range of $0.5 \%$, the fatigue life in lithium is a fartor of 0.5 lower thon that in a sodium environment.

Figure 7.4 .1 shows the results for two tests, i.e., at a strain rate of $4 \times 10^{\cdots 4} \mathrm{~s}^{-1}$ and with a hold period of $90 \mathrm{ks}$ at $0.3 \%$ strain In tension prior to fatigue cycling, which were conducted to determine the effect of lithium exposure time on fatigue life. The results show that preexpusure of the specimens at $0.3 \%$ tensile strain for $90 \mathrm{ks}$ (corresponds to 235,000 cycles of continuous-cycle fatigue test at total strain range of $20.5 \%$ and $4 \times 10^{-3} \mathrm{~s}^{-1}$ strain rate) has no effect on the fatigue life of HT-9 alloy in a lithium environment. 
TABLE 7.4.1. Concentrations of Nitrogen and Carbon in Lithium Obtained after Different Loop Operating Time

\begin{tabular}{cccc}
$\begin{array}{c}\text { Loop Operating } \\
\text { Time, Ms }\end{array}$ & $\begin{array}{c}\text { Maximum } \\
\text { Temperature, } \\
\mathrm{K}\end{array}$ & $\begin{array}{c}\text { Nitrogen, } \\
\text { wppm }\end{array}$ & $\begin{array}{c}\text { Carbon, } \\
\text { wppm }\end{array}$ \\
\hline 0.36 & 623 & 475 & - \\
0.54 & 623 & 417 & - \\
2.52 & 755 & 86 & - \\
2.88 & 1 & - & 9 \\
8.28 & & 130 & - \\
8.64 & & - & 11 \\
14.04 & & 1220 & - \\
\hline
\end{tabular}

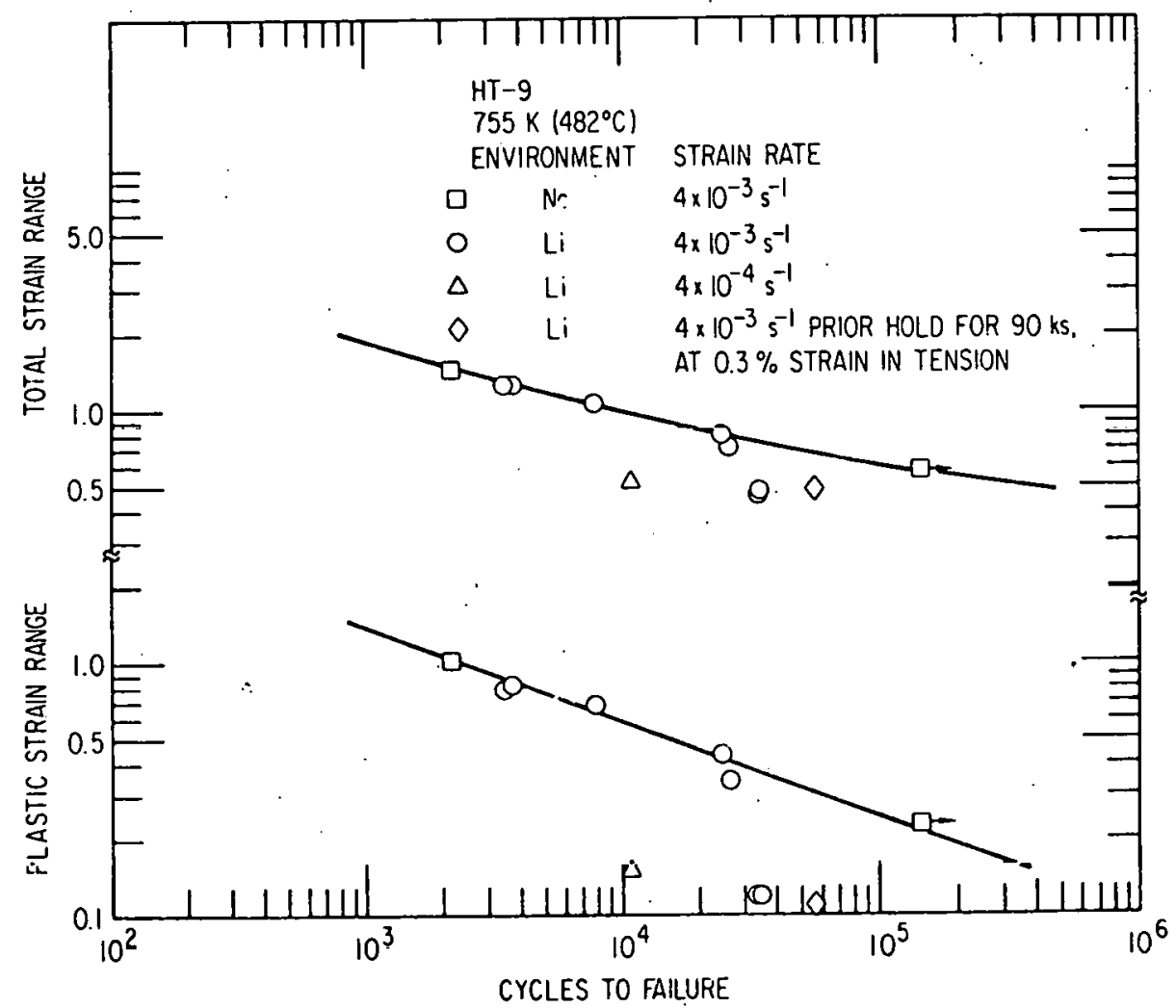

Fig. 7.4.1. Total and Plastic Strain Range vs Cycles to Failure for HT-9 Alloy Tested in Lithium at $755 \mathrm{~K}$. 
The fracture surface and the longitudinal section of the fatigue specimens were examined metallographically to evaluate the influence of test conditions on the mode of fracture and corrosion. The results show that the specimens which follow the power-law strain-life relationship have a typical fatigue fracture surface and little or no internal corrosive attack. However, the specimens with a reduced fatigue life show a partial intergranular fracture mode, i.e., intergranular fracture near the specimen gauge surface, and considerable internal corrosive penetration. Micrographs of the longitudinal section of the specimens from two tests are shown in Fig. 7.4.2. Both specimens show $75-10 \mu m$ corrosive attack along the entire gauge length and intergranular corrnainn which extends $100-300 \mu \mathrm{m}$. The specimen tested at the lower strain rate shows greacer intergranular attark herause of the longer duration of thc test.

The concentration of nitrngen in lithium during most of the fatigue tests was between 80 and $130 \mathrm{ppm}$. However, for the fatigue tests which show a reduced fatigue life, nitrogen concentration in lithium was $>1000 \mathrm{ppm}$. It is probable that the reduction in fatigue life of the HT-9 alloy is due to the greater corrosive attack caused by a high concentration of nitrogen in lithium. Fatigue tests at low strain range, i.e., $<0.7 \%$, will be repeated in lithium containing $\sim 100 \mathrm{ppm}$ nitrogen to evaluate the influence of nitrogen on the fatigue life of the HT-9 alloy in lithium.

\subsubsection{Compatibility}

The first test to study the compatibility of structural materials with candidate solid tritium-breeding materials has been completed. Flat specimens of HT-9 alloy, Type 316 stainless steel, and . Inconel 625 were exposed in contact with solid $\mathrm{Li}_{2} \mathrm{O}$, $\mathrm{LiAlO}_{2}$, and $\mathrm{Li}_{2} \mathrm{SiO}_{3}$ material in a helium environment for $\sim 6.84 \mathrm{Ms}(\sim 1900 \mathrm{~h})$ at $873 \mathrm{~K}$. Each specimen was $\sim 13 \mathrm{~mm}$ on a side with thickness between 0.8 and $1.4 \mathrm{~mm}$. The specimens were weighed and measured before and after the exposure to determine welght change or metal loss. 


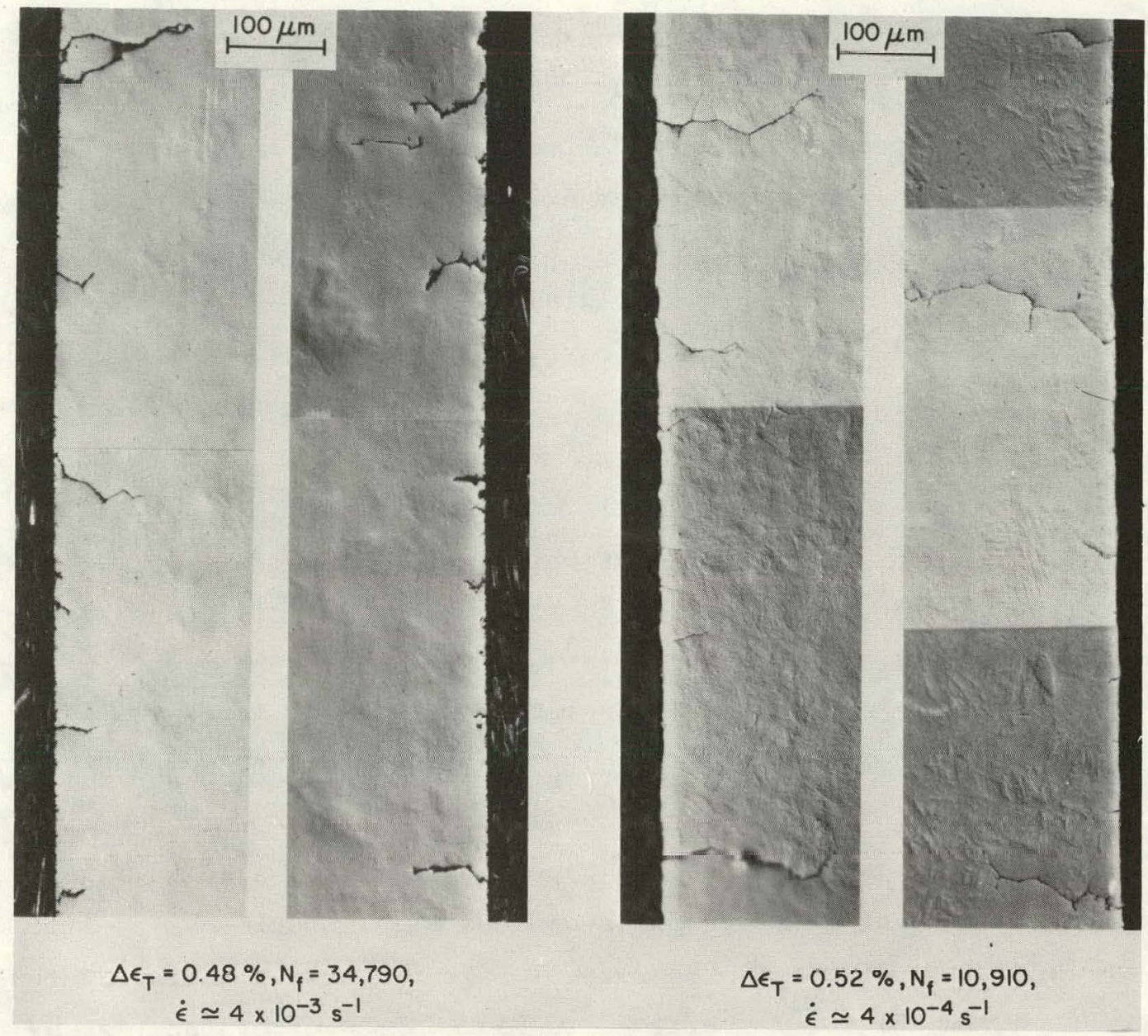

Fig. 7.4.2. Micrographs of the Longitudinal Section of HT-9 Specimens Tester in T.ithium at $755 \mathrm{~K}$. 
After exposure, all the specimens developed an adherent grayish-black surface scale, with the exception of Type 316 stainless steel specimen exposed with $\mathrm{Li}_{2} \mathrm{O}$, which had a brownish-black scale. Scanning electron micrographs of the surface of all the specimens are shown in Fig. 7.4.3. The composition of the surface scales, determined by energy dispersive $x$-ray and electron microprobe analyses, is given in Table 7.4.2. The results show that the surface scales on HT-9 and Type 316 stainless steel specimens exposed either with $\mathrm{LiAlO}_{2}$ or $\mathrm{Li}_{2} \mathrm{SiO}_{3}$ essentially consist of iron and chromium oxides, whereas the scales on Inconel 625 specimens exposed with $\mathrm{LiAlO}_{2}$ or $\mathrm{Li}_{2} \mathrm{SiO}_{3}$ contain chromium and nickel oxides. These specimens show negligible interaction between the ceramic and corrosion scale. The opaque glassy patches (Fig. 7.4.3) observed on the surtaces of these specimens are pieces of the ceramic material. Occasionally, a significant amount of carbon was detected in the opaque patches, possibly present as a carbonate.

The three specimens which were exposed with $\mathrm{Li}_{2} \mathrm{O}$ show a different behavior. These specimens show substantial interaction between the ceramic and corrosion scale. For these specimens, the concentrations of chromium, iron, and nickel in the scale is lower than that observed in the specimens exposed with $\mathrm{LiAlO}_{2}$ or $\mathrm{Li}_{2} \mathrm{SiO}_{3}$. The corrosion scale on these specimens possibly contains a significant amount of lithium, particularly the scale observed on Type 316 stainless steel. X-ray diffraction analysis of the Type 316 stainless steel specimens revealed that the surface scale primarily consists of $\mathrm{Li}_{2} \mathrm{CO}_{3}$, thereby giving it the brownish color. $\mathrm{Li}_{2} \mathrm{CO}_{3}$ is believed to have formed after the test by interaction with moisture and carbon dioxide in the air. Characterization of the other specimens is in progress to identify the corrosion products in the surface scales.

$\Lambda$ detailed cxamination of the cross scetion of the spccimens is being conducted to determine the thickness of the corrosion scale and the distribution of corrosion products in the scale. Preliminary results are given in Table 7.4.3. The HT-9 specimens exposed with $\mathrm{LiAlO}_{2}$ or $\mathrm{Li}_{2} \mathrm{SiO}_{3}$ have an $\sim 5-\mu \mathrm{m}$-thick surface scale, whereas the thickness of the corrosion scale on HT-9 and Type 316 stainless steel exposed with $\mathrm{Li}_{2} \mathrm{O}$ is 12 and $18 \mu \mathrm{m}$, respectively. Furthermore, the Type 316 stainless 


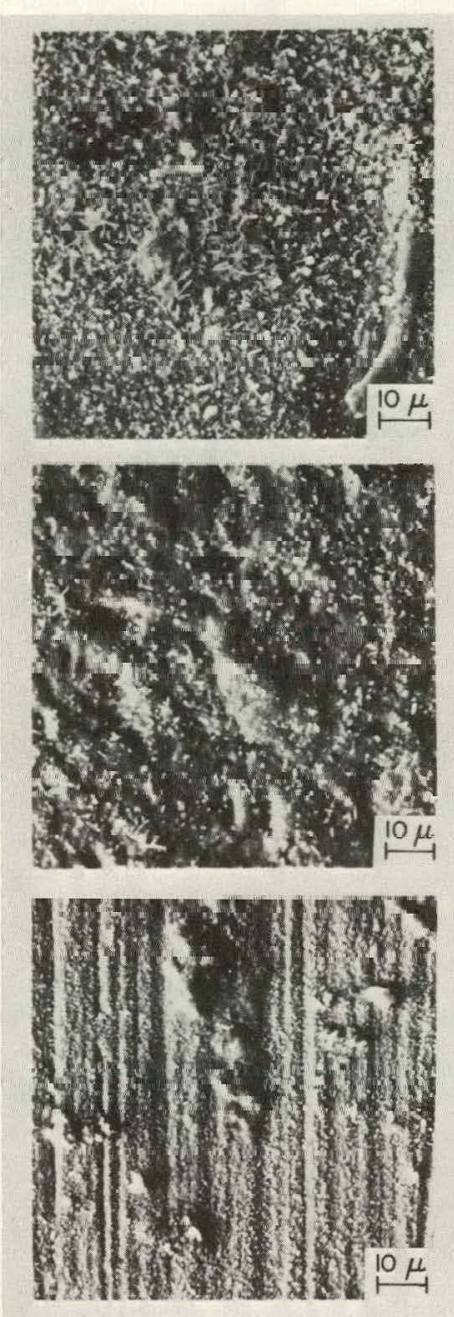

A
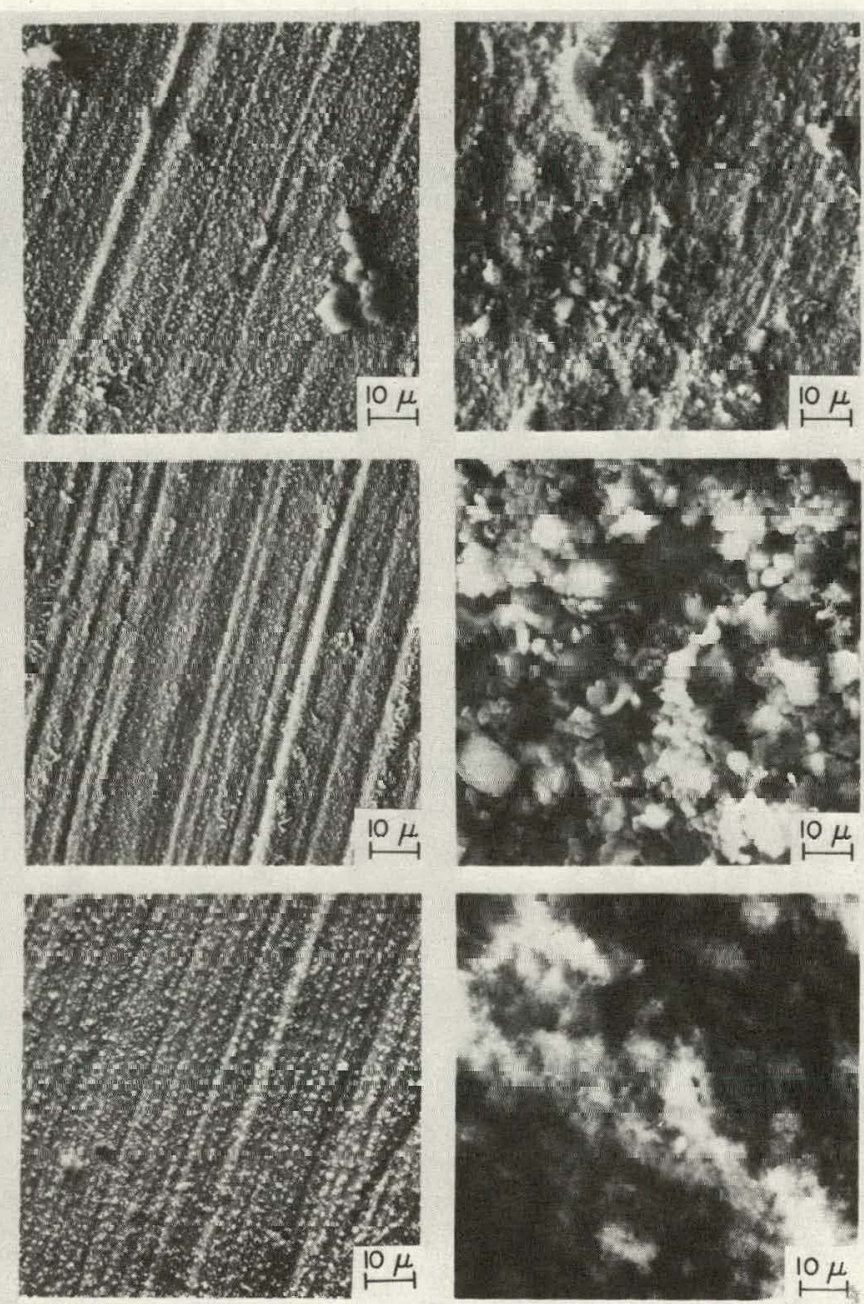

B

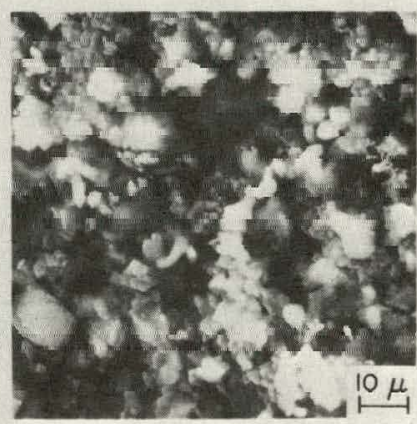

TYPE

$3165 S$

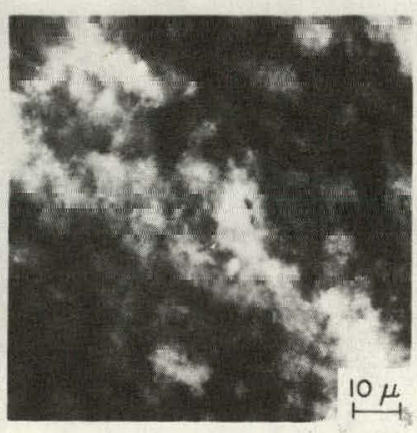

C

Fig. 7.4.3. Scanning Electron Micrographs of the Surfaces of HT-9, Type 316 Stainless Stee1, and Inconel 625 Specimens after Expusure with Solid Brccding Materials. (A) $\mathrm{LiAlO}_{2}$, (B) $\mathrm{Li}_{2} \mathrm{SiO}_{3}$, and (c) $\mathrm{Li}_{2} \mathrm{O}$. 
TABLE 7.4.2. Composition (wt \%) of Surface Scale on Corrosion Specimens

\begin{tabular}{|c|c|c|c|c|c|c|c|c|c|}
\hline Alloy & Ceramic & 0 & $\mathrm{Si}$ & S & $\mathrm{Cr}$ & Mn & $\mathrm{Fe}$ & $\mathrm{Ni}$ & Total \\
\hline \multirow[t]{3}{*}{ HT -9} & $\mathrm{LiAlO}_{2}$ & 22.5 & 0.7 & 0.1 & 27.9 & 9.6 & 35.5 & 0.2 & 96.5 \\
\hline & $\mathrm{Li}_{2} \mathrm{SiO}_{3}$ & 22.9 & 1.6 & '- & 34.0 & 1.1 & 30.0 & 0.2 & 89.8 \\
\hline & $\mathrm{Li}_{2} \mathrm{O}$ & 24.4 & 0.4 & - & 21.0 & 0.7 & 19.6 & 0.8 & 56.9 \\
\hline \multirow[t]{3}{*}{ Type 316 SS } & $\mathrm{LiAlO}_{2}$ & 26.3 & 0.2 & 0.1 & 44.2 & 2.6 & 16.3 & 2.1 & 91.8 \\
\hline & $\mathrm{Li}_{2} \mathrm{SiO}_{3}$ & 24.1 & 1.7 & - & 37.6 & 0.7 & 22.4 & 3.2 & 89.7 \\
\hline & $\mathrm{Li}_{2} \mathrm{O}$ & 26.3 & - & - & 0.3 & - & 7.6 & 0.1 & 34.3 \\
\hline \multirow[t]{3}{*}{ IN 625} & $\mathrm{LiAlO}_{2}$ & 34.6 & 0.3 & 0.1 & 42.1 & 0.3 & 0.9 & 15.4 & 93.7 \\
\hline & $\mathrm{LL}_{2} \mathrm{SIO}_{3}$ & 26.2 & 0.3 & - & 35.5 & 0.1 & 1.1 & 23.2 & 80.6 \\
\hline & $\mathrm{Li}_{2} \mathrm{O}$ & 22.8 & 0.1 & -. & 13.5 & 0.1 & 1.7 & 35.9 & 74.1 \\
\hline
\end{tabular}

TABLE 7.4.3. Summary of Corrosion Data

\begin{tabular}{|c|c|c|c|c|c|}
\hline Ceramic & Alloy & $\begin{array}{l}\text { Ceramir/A1lny } \\
\text { Interaction }\end{array}$ & $\begin{array}{c}\text { Corrosion } \\
\text { Thicknese, } \\
\mu \mathrm{m}\end{array}$ & Scale Phases $^{a}$ & Remarks \\
\hline $\mathrm{Li}_{2} \mathrm{O}$ & $\begin{array}{l}\text { HT-9 } \\
316 \text { SS } \\
\text { IN } 625\end{array}$ & Strong & $\begin{array}{r}12 \\
18 \\
\mathrm{~b}\end{array}$ & $\begin{array}{l}\overline{-} \\
\overline{-}\end{array}$ & $\sim 35 \mu$ reaction zone \\
\hline $\mathrm{LiAlO}_{?}$ & $\begin{array}{l}\text { HT-9 } \\
316 \text { SS } \\
\text { IN } 625\end{array}$ & $\left.\right|_{1} ^{\text {Weak }}$ & $\begin{array}{l}5 \\
b \\
h\end{array}$ & $\begin{array}{l}(\mathrm{Fe}, \mathrm{Cr})_{3} \mathrm{O}_{4} \\
(\mathrm{Cr}, \mathrm{Fe})_{2} \mathrm{O}_{3} \\
\mathrm{NiCr}_{2} \mathrm{O}_{4}\end{array}$ & $\begin{array}{l}\text { Scale rumtilus } 29 \% \text { Mn } \\
\text { Scale contains } 23 \% \text { Mn }\end{array}$ \\
\hline $\mathrm{Li}_{2} \mathrm{SiO}_{3}$ & $\begin{array}{l}\text { HT-9 } \\
316 \text { SS } \\
\text { TN } 625\end{array}$ & Weak & $\begin{array}{l}6 \\
b \\
b\end{array}$ & $\begin{array}{l}(\mathrm{Fe}, \mathrm{Cr}){ }_{3} \mathrm{O}_{4} \\
(\mathrm{Cr}, \mathrm{Fe})_{2} \mathrm{O}_{3} \\
\mathrm{NiCr}{ }_{2} \mathrm{O}_{4}\end{array}$ & \\
\hline
\end{tabular}

${ }^{a}$ Tentative identification based on microprobe analysis.

banalysis in progress. 
steel specimen had $235-\mu m-t h i c k$ outer layer of reaction zone which consisted of ceramic material embedded with pieces of corrosion products. It is possible that the HT-9 specimen also had a similar reaction zone which broke off when the alloy and ceramic specimens were separated. The concentration profiles for iron, chromium, and oxygen near the surface of these specimens are shown in Fig. 7.4.4. The HT-9 specimens exposed with $\mathrm{LiAlO}_{2}$ or $\mathrm{Li}_{2} \mathrm{SiO}_{3}$ show an enrichment of chromium in the scale and a depletion of chromium near the surface. The concentration of iron decreases gradually across the corrosion scale. A similar behavior is observed in the HT-9 and Type 316 stainless steel specimens exposed with $\mathrm{Li}_{2} \mathrm{O}$, except that the concentration of iron in the scale is significantly higher. The reaction zone on Type 316 stainless steel specimen contains iron and oxygen with no chromium. The corrosion products will be identified by $x$-ray diffraction analysis.

\subsubsection{Conclusions}

1. Liquid lithium environment has a strong effect on the fatigue life of HT-9 alloy. At a total strain range of $0.5 \%$, the fatigue life in lithium is a factor of $\sim 5$ lower than that in a liquid sodium environment.

2. The specimens tested in lithium at $755 \mathrm{~K}$ show considerable intergranular corrosion.

3. Compatibility tests with solid $\mathrm{Li}_{2} \mathrm{O}, \mathrm{LiAlO}_{2}$, and $\mathrm{Li}_{2} \mathrm{SiO}_{3}$ tritium-breeding materials indicate that $\mathrm{Li}_{2} \mathrm{O}$ is the most reactive of the three breeding materials. The thickness of the corrosion scale on $\mathrm{HT}-9$ specimen exposed with $\mathrm{Li}_{2} \mathrm{O}$ is 23 times greater than those observed on specimens exposed with either $\mathrm{LiAlO}_{2}$ or $\mathrm{Li}_{2} \mathrm{SiO}_{3}$.

\subsubsection{References}

1. 0. K. Chopra and D. L. Smith, "Environmental Effects on Properties of Ferritic Steels," ADIP Quarterly Progress Report, March 31, 1980, DOE/ER-0045/2, pp. 181-183.

2. D. L. Smith; O. K. Chopra, and R. R. Schlueter, "Environmental Effects on Properties of Ferritic Steels," ADIP Quarterly Progress Report, December 31, 1979, DOE/ER-0045/1, pp. 115-118.

3. O. K. Chopra and D. L. Smith, "Environmental Effects on Properties of Ferritic Steels," ADIP Progress Report, June 30, 1980. 

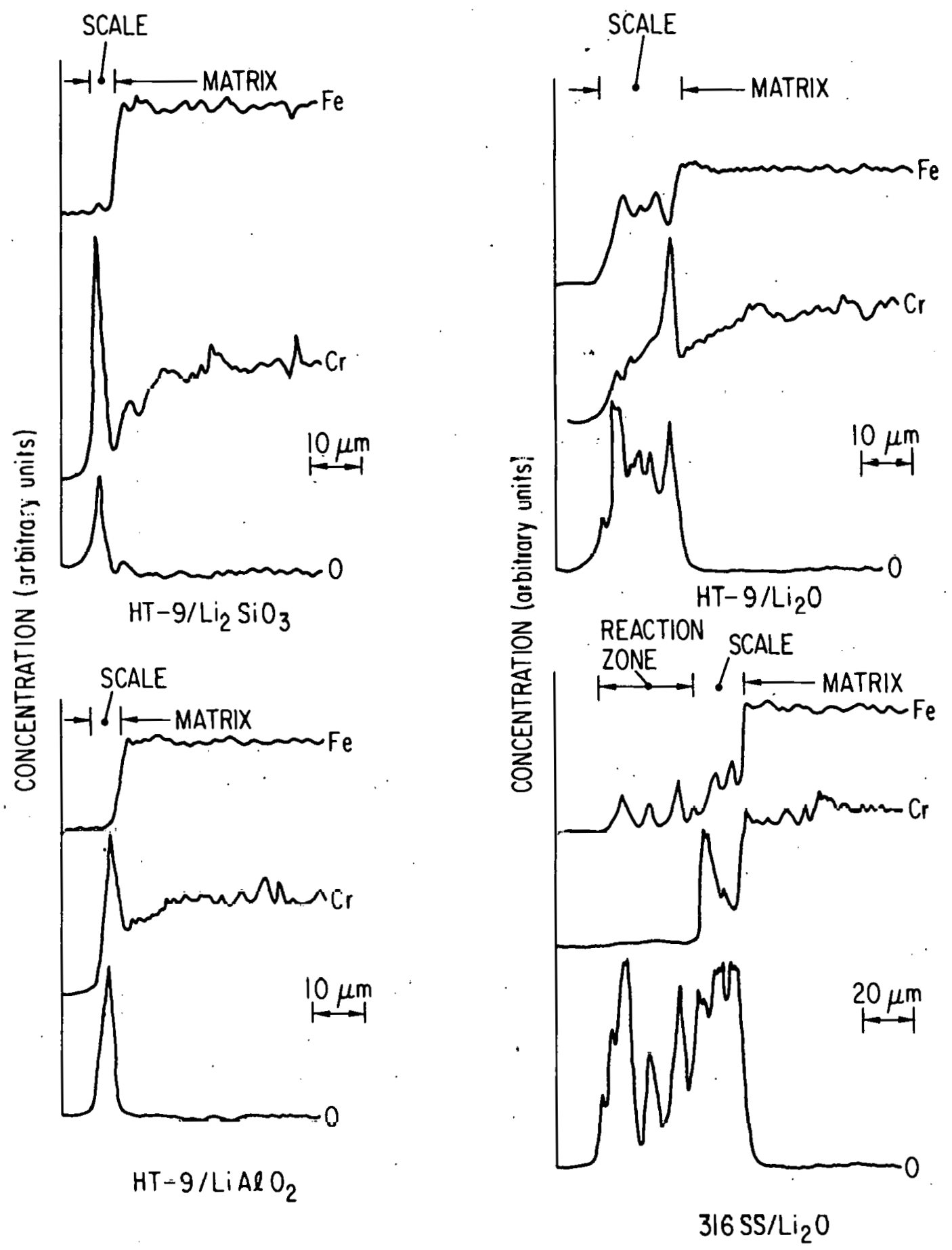

Fig. 7.4:4. Concentration Profiles for Iron, Chromium, and Oxygen Across the Cross Section of HT-9 and Type 316 Stainless Steel Specimens Exposed with Solid Breeding Materials. 
7.5 CALCULATIONS OF HYDROGEN ISOTOPE LOADING IN HT9 FIRST WALL STRUCTURES

R. E. Stoltz, M. I. Baskes and G. W. Look (Sandia National Laboratories, Livermore, CA)

\subsubsection{ADIP Task}

The Department of Energy (DOE)/Office of Fusion Energy (OFE) has cited the need for these data under the ADIP Program Task, Ferritic Alloy Development (Path E).

\subsubsection{Objective}

The goal of this study is to evaluate the hydrogen compatibility of a $12 \mathrm{Cr}$-lMo ferritic/martensitic steel for use in first wall and blanket structures. This contribution focuses on calculations of hydrogen isotope loadings in HT9 during operation of a pulsed Tokamak device.

\subsubsection{Summary}

Calculations of the hydogen level in first wall and blanket structures have been made using HT9 as the material of construction. Both directly injected deuterium and tritium profiles and hydrogen profiles from $(n, p)$ reactions have been calculated over a temperature range from 473 to $638 \mathrm{~K}$. Two boundary conditions have been assumed: zero surface concentration and a concentration set by the surface recombination reaction of hydrogen ions th form hydrogen molecules. The results indicate that under the most severe conditions, peak hydrogen levels will not exceed 0.5 appm and will likely be far lower. 


\subsubsection{Progress and Status}

\subsubsection{Details of the Calculation}

Calculations of the hydrogen. isotope loading during operation of a pulsed Tokamak reactor were performed. Profiles were determined both for deuterium and tritium directly injected from the plasma, and for hydrogen produced through $(n, p)$ reactions in an alloy with HT9 composition. As a starting point for the calculations, machine parameters given in Table $I$ were used. The parameters are a combination of conditions from the INTOR and ETF designs (1).

Table I

\section{Parameters for Hydrogen Profile Calculations}

$$
\begin{aligned}
& \text { Pulse Duration : } 100 \text { seconds on, } 35 \text { seconds off } \\
& \text { Wall Material : HT9 (composition in Table II) } \\
& \text { Wa11 Thickness : } 1.0 \mathrm{~cm} \\
& \text { Plasma Edge Temp : } k T=150 \mathrm{eV} \\
& \mathrm{D}, \mathrm{T} \text { Flux } \quad: \quad 3.2 \times 10^{16} \mathrm{particles} / \mathrm{cm}^{2}-\mathrm{sec} \\
& \text { Neutron Energy Flux: } 1.5 \text { megawats } / \mathrm{m}^{2} \\
& K \text { for Recombination } \\
& \text { Reaction : } 10^{-16} \mathrm{~cm}^{4} / \mathrm{sec} \\
& \text { Temperatures } \quad: \quad 473,573,638 \mathrm{~K}\left(200,300,365^{\circ} \mathrm{C}\right)
\end{aligned}
$$

The calculations involve solving the diffusion equation by numercial methods as outlined in (2) and are similar to those made tor austenitic steels and 'li alloys (3). The calculation is repeated for successive machine pulse cycles (a total duration of 135 seconds for this case) until a steady state profile is reached. The calculation is performed additionally at the end of the first 100 seconds, simulating a beam-on condition, and at 135 seconds, giving the beam-off profile. In the results section, steady state beam-on profiles are given as these represent worst case conditions. 
In order to calculate the profile for directly injected $D$ and $\mathrm{T}$, a Monte-Carlo program, TRIM, using $10^{5}$ particle histories was used to determine the starting concentration profiles (4). Fixed temperatures of 473,573 and $638 \mathrm{~K}$ were used along with a. diffusivity of $D=4.2 \times 10^{-4} \exp [-0.06 \mathrm{eV} / \mathrm{kT}], \mathrm{cm}^{2} / \mathrm{sec}$, to calculate the final profiles. As will be shown in the results section, the final steady state profile has a maximum near the input surface $(X=0)$, due to the shape of the initial concentration profile which has maximum at a depth of $\approx 1-2 \mathrm{~nm}$ (4).

Hydrogen profiles produced through $(n, p)$ reactions were determined using the input wall energy loading of 1.5 megawatts $/ \mathrm{m}^{2}$. An alloy of nominal HT9 concentration, as given in Table II, was used along with published neutron cross sections for the various elements. As will be shown, the final profiles are peaked near the mid-thickness of the first wall because the $(n, p)$ reactions occur uniformly throughout the material.

Table II

HT9 Composition, WT\%

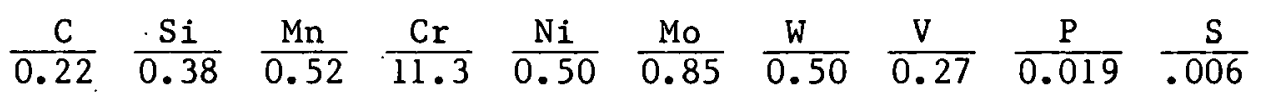

Finally, and most important in the analysis, two different surface boundary conditions were employed. The first assumes no surface barrier to hydrogen diffusion. Since the plasma side hydrogen fugacity is very low the surface concentration is set to zero. The heat transfer surface or backside concentration (at $X=1.0 \mathrm{~cm}$ ) was also set to zero. Though some hydrogen build-up may occur at the coolant side, no information as to levels is available and so a zero concentration was assumed.

A second boundary condition assumed for the calculation is that of a surface recombination limited level of hydrogen. Previous calculations of hydrogen levels suggested that total amounts way be in the $10^{-3}-10^{-1}$ appm range. At this low level, the exit 
fugacity may be determined by the availability of two hydrogen surface ions to recombine for the formation of a $\mathrm{H}_{2}$ molecule. A recent theoretical treatment has estimated the reaction rate parameters for this recombination step (5), and experimental data confirms the calculated case for b.c.c. iron (6). In the present calculations, a reaction constant $\mathrm{K}=10^{-16} \mathrm{~cm}^{4} / \mathrm{sec}$ was used.

\subsubsection{Results of the Calculation}

The results of the profile determinations are given in Figuxes 1 , 2 and 3. F1gure 1 is for the $D, T$ profiles with a zero surface concentration, at three different temperatilres. Figure 2 is a similar plot for the hydrogen produced by $(n, p)$ reactions also as a fulletion of temperature and with zero surface concentration. Figure 3 shows plots for both $D, T$ and $(n, p)$ profiles only at $638 K$, but in this case with a surface recombination limited boundary condition.

In order to compare the varinus caseo in dela1l, the maximum concentration and location of the peak for all the curves in Figures 1-3 are given in Table III. It is interesting to note that the maximum concentration under any condition is less than 1 atomic ppm.

\subsubsection{Discuss1on}

A number of points emerge from the data of Figures 1-3. First, varying the temperature of the first wall from 473 to $638 \mathrm{~K}$ $\left(200\right.$ to $365^{\circ} \mathrm{C}$ ) has little effect on the concentration levels for either the $D, T$ profiles or for $(n, p)$ produced hydrogen. The factor influencing this behavior is the activation energy for diffusion in b.c.c. iron, $-0.06 \mathrm{eV}$, which $\mathrm{is}$ low compared to that for austenticic steels at $-0.55 \mathrm{QV}$. The dictual values for the diffusivity at temperatures of 473 to $638 \mathrm{~K}$ range from $10^{-6}$ to $10^{-4} \mathrm{~cm}^{2} / \mathrm{sec}$. These values are sufficiently high that, in the cases for Figures 1 and 2 where a zero surface concentration is assumed, the overall level of hydrogen in extremely low. 


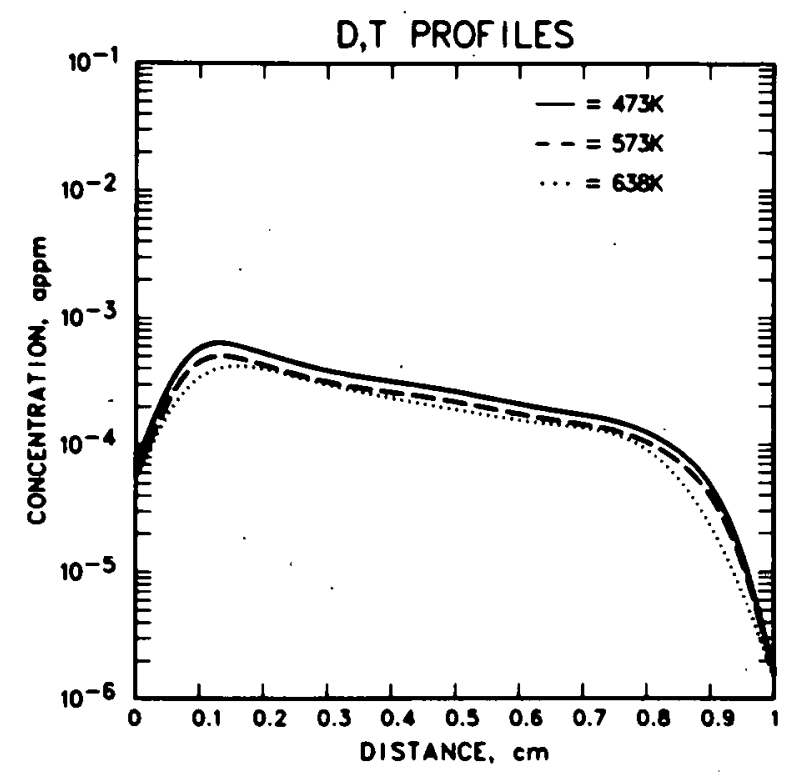

Figure 7.5.1 Hydrogen isotope (deterium and tritium) profiles from direct injection from the plasma, with a zero surface concentration boundary condition.

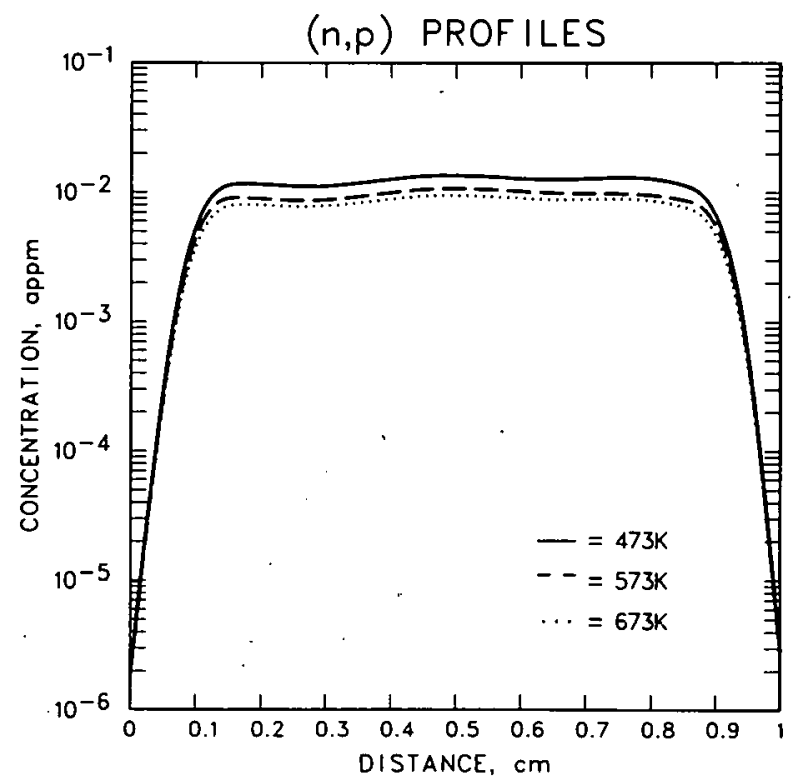

Figure 7.5.2 Hydrogen concentration from $(n, p)$ reactions with a zero surface concentration boundary condition.

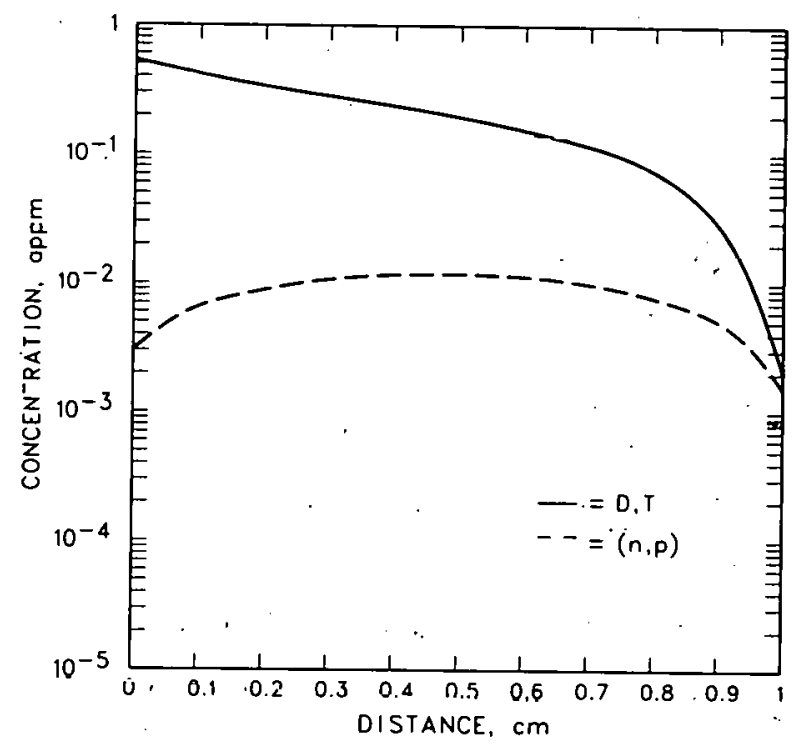

Figure 7.5.3 Hydrogen profiles from direct injection of $D, T$ and from $(n, p)$ reactions, with a surface recombination limited boundary condition at $638 \mathrm{~K}$. 
Table III

Maximum Concentrations and Peak Locations for Hydrogen

Condition

$(D, T)$, zero surface concentration:

$473 \mathrm{~K}$

$573 \mathrm{~K}$

$638 \mathrm{~K}$

$(n, \dot{p})$, zero surface coilentration:

$473 \mathrm{~K}$

$573 \mathrm{~K}$

$638 \mathrm{~K}$
Concentration, appm
Distance from Input Surface, $\mathrm{cm}$

$(D, T)$ surface recombination limiled:

$$
638 \mathrm{~K}
$$$$
0.53
$$

$0.13 \times 10^{-1}$

$0.10 \times 10^{-1}$

0.46

$$
\begin{aligned}
& 0.48 \times 10^{-4} \\
& 0.56 \times 10^{-5} \\
& 0.56 \times 10^{-5}
\end{aligned}
$$

$(n, p)$ surface recombination limited:

$$
638 \mathrm{~K}
$$

$$
0.12 \times 10^{-1}
$$

0.46

The factor of groatrat iupurcance in the calculation of hydrogen levels appears to be the assumed boundary conditions, as evidenced from a comparison of Figure 3 with the data 1 in figures 1 and 2 at $638 \mathrm{~K}$. The hold-up of hydrogen at the surface due to the recombination reaction allows the material to fill up io an essentially uniform level of hydrogen. This surface concentration is direrty related to the $K$ assumed for the reaction (5). While the choire of $K=10^{-16}$ cill 4 occ was in the mid range of the data for iron (see Ref. 5), the surface concentration varies as $K^{-1 / 2}$ so that a ten Fold decrease in $K$ would increase the concentration only by a factor of three. 
The most important result of these calculations is that hydrogen levels in ferritic steels due to both direct injection and nuclear reaction are less than 1 appm. This is in contrast to austenitic steels where, due to the million fold decrease in diffusivity, the levels can reach 10-30 appm. Once can begin to assess the effect of this hydrogen level in many ways. First the residual hydrogen levels present in most construction steels is on the order of $1-5$ appm (7). Thus the additional increase from the plasma is negligible by comparison. Second, the long-time exposure to high temperatures in service would tend to drive out any residual hydrogen, in the same way that the injected hydrogen levels are reduced by diffusion out of the sample. Finally, preliminary measurements of the ductility of HT9 in hydrogen environments (8) indicates that in 1 atm hydrogen (which would give a equilibrium concentration of $\sim 2$ appm) the ductility is only slightly reduced. Pressures upwards of $3.5 \mathrm{MPa}$ (5000 psi) corresponding to concentrations in the 20-40 appm range are necessary for severe embrittlement.

All of the above considerations are based on the behavior of unirradiated materials. As shown by Brinkman and Beeston (9), the introduction of 1-5 appm hydrogen into irradiated HY-80 pressure vessel steel can lead to severe embrittlement. This is somewhat of an overtest, however, in that extra precautions were taken to assure that the hydrogen was present during the test. In actual practice, most of the hydrogen present in the first wall and blanket structure would diffuse out. Even hydrogen trapped at irradiation-induced defects would be sensibly detrapped at temperatures of $573 \mathrm{~K}$ if one assumes a maximum binding energy to traps of $\sim 1.0 \mathrm{eV}$. Experiments are currently underway to simulate the strength increases that occur by irradiation through the use of special tempering treatments. Precharged hydrogen will be used in attempt to separate the effects of radiation hardening from defect trapping on the level of hydrogen susceptibility. 


\subsubsection{Conclusions}

1. Increasing operating temperatures from 473 to $638 \mathrm{~K}$ (200 to $365^{\circ} \mathrm{C}$ ) has little effect on the total calculated hydrogen content in first wall structures.

2. With a zero surface concentration boundary condition, hydrogen levels do not exceed $10^{-2}$ appm in HT9 type alloys. The extremely high diffusivity is responsible for this low level of hydrogen.

3. Assuming that the surface concentration is set by the hydrogen recombination reaction, the calculated levels of hydrogen do not exceed U.J appm.

\subsubsection{References}

1. Personal communication, Paul Seeger, Oak Ridge National Laboratory, October, 1980.

2. M. I. Baskes, "DIFfUSE: A Code to Calculate One Dimensional Diffusion and Trapping", SAND80-8201, Sandia National Laboratories, Livermore, CA, January 1980.

3. G. W. Look and M. I. Baskes, "Hydrogen Profiles in Tokamak Fusion Reactor First Wa1s", Nucl. Malls. 85 and 86: 99j-999 (1979).

4. J. P. Biersack and L. G. Haggmarks," A Monte-Carlo Program for the Transport of Energetic Ion in Amorphous Targets", Nucl. Instr. and Methods, 174: 257 (1980).

5. M. I. Baskes, "A Calculation of the Surface Recombination Rate Constant for Hydrogen İsotopes on Metals", SAND80-8660, Sandia National Laboratories, Livermore, CA, April 1980.

6. F. Waelbroenk, I. Ali-Kahn, K. J, Nietz, M. Profant, and.F. Waelbrueck, J. Nucl. Matlo., 85 and 86: 1151 (1979).

7. H. H. Johnson, "Hydrogen Gas Embrittlement", in Hydrogen in Metals", I. M. Bernstein and A. W. Thompson, Eds, ASM, 1974.

8. R. E. Stoltz, "Mechanical. Property Measurements of HT9 in Hydrogen: 25 to $400^{\circ} \mathrm{C}$ ", ADIP Quarterly Progress Report of Period Ending March 31, 1980, DOE/ER-0045/2 ORNL, June 1980. 
9. C. R. Brinkman and J. M. Beeston, "The Effect of Hydrogen on the Ductile Properties of Irradiated Pressure Vessel Steels," ASTM STP 484, ASTM, 1970, p. 42. 
160

BIanK 
8. STATUS OF IRRADIATION EXPERIMENTS AND MATERIALS INVENTORY 


\subsection{IRRADIATION EXPERIMENT STATUS AND SCHEDULE}

The following bar charts show the schedule for all ADIP reactor irradiation experiments. Experiments are presently under way in the Oak Ridge Research Reactor (ORR) and the High Flux Isotope Reactor (HFIR), which are mixed spectrum reactors, and in the Experimental Breeder Reactor (EBR-II), which is a fast reactor.

During the reporting period irradiation was begun for two experiments: HFIR-CTR-30 and -32, both in the HFIR. These experiments were designed to evaluate the effects of irradiation on microstructure and ductility. Specimens trom alloys in all five ADIP alloy paths are included in these experiments: A similar third capsule, HFIR-CTR-31, is scheduled for insertion on October $1,1980$. 


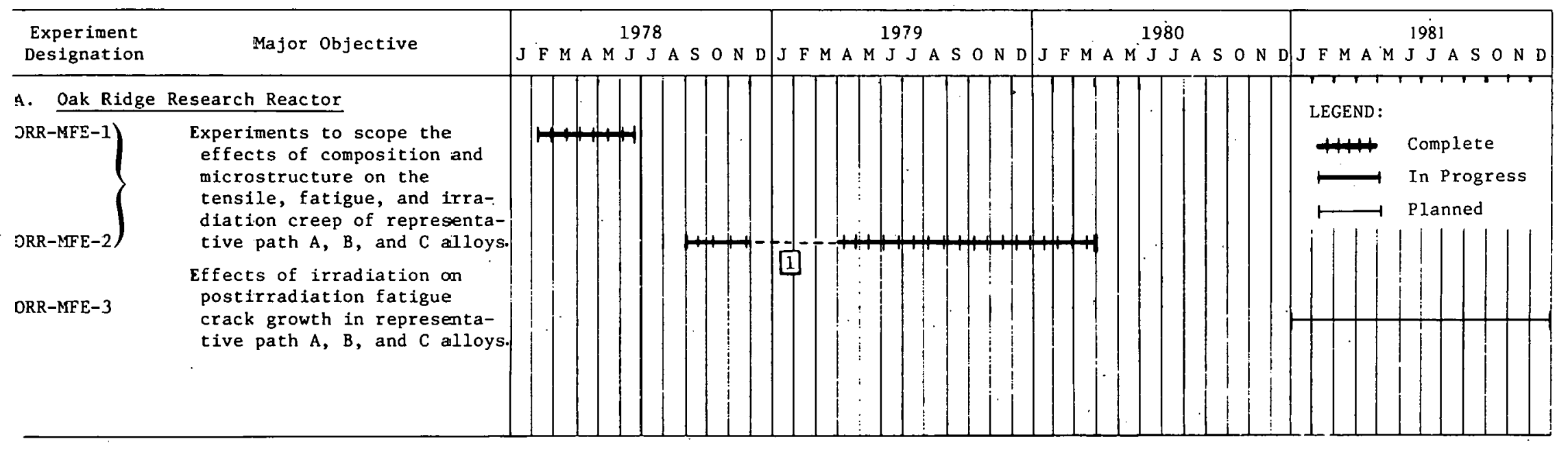

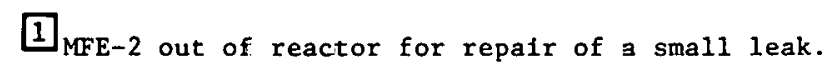




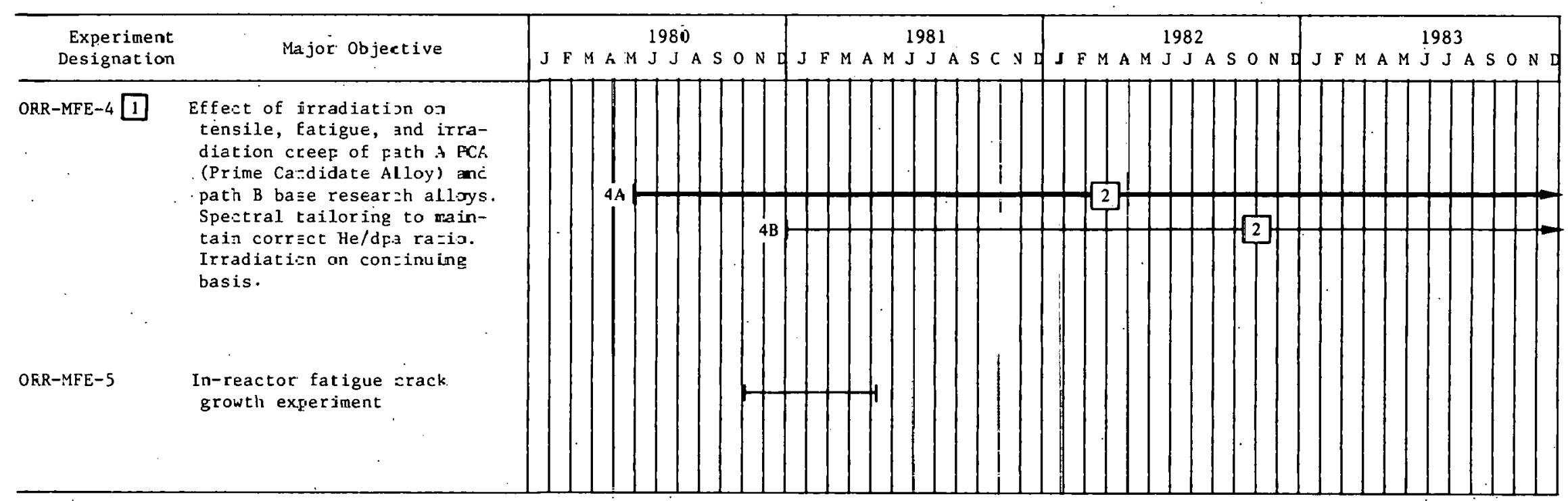

11 MFE-4A will operate at $\$ 00$ and $400^{\circ} \mathrm{C}$. MFE-4B will operate at 500 and $600^{\circ} \mathrm{C}$.

2 Approximate scheciule for specimen charge out. 


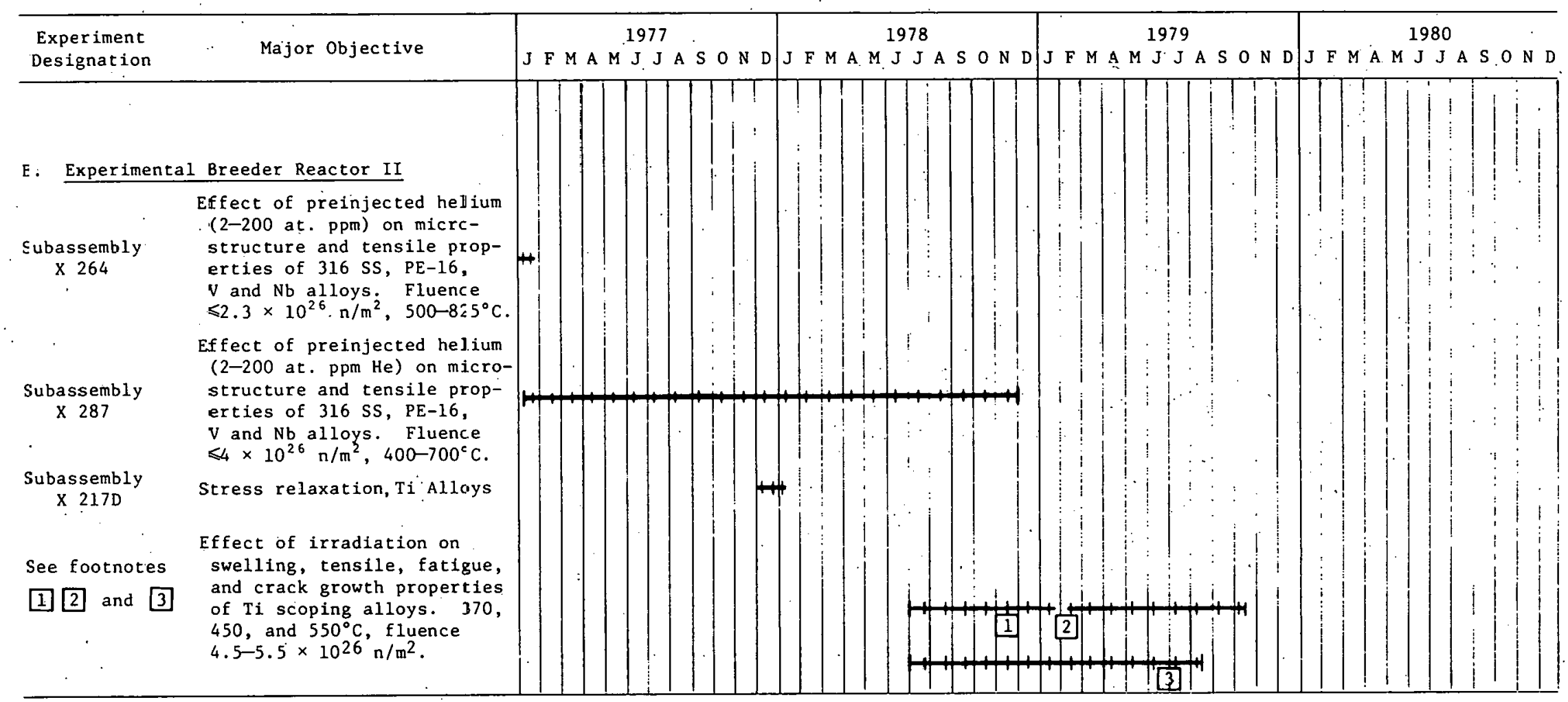

$1]_{E B R-I I}$, row 2, pins $B 285$ and $B 286$.

2 Subassembly removed for EBR-II run 99.

3 Pin B284, row 2 for runs $96-98$; row 4 for runs $100-102$. 


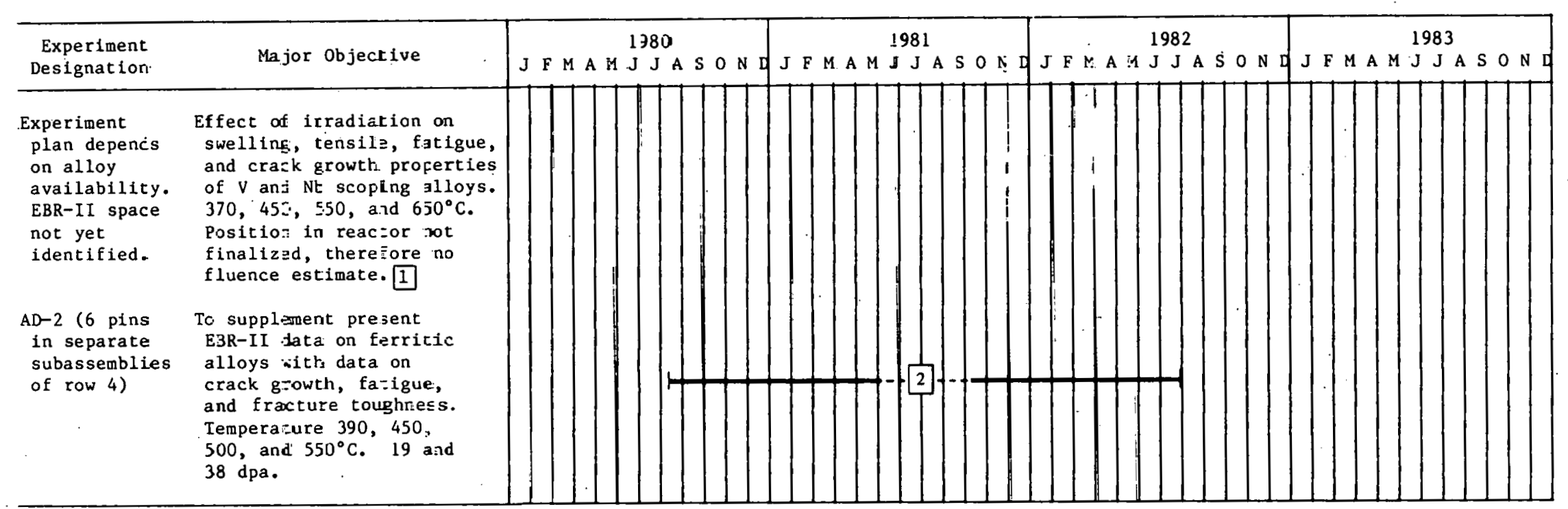

1 Delayed for undeternined period.

2 .

Interim examination. Experiment out of reactor. 


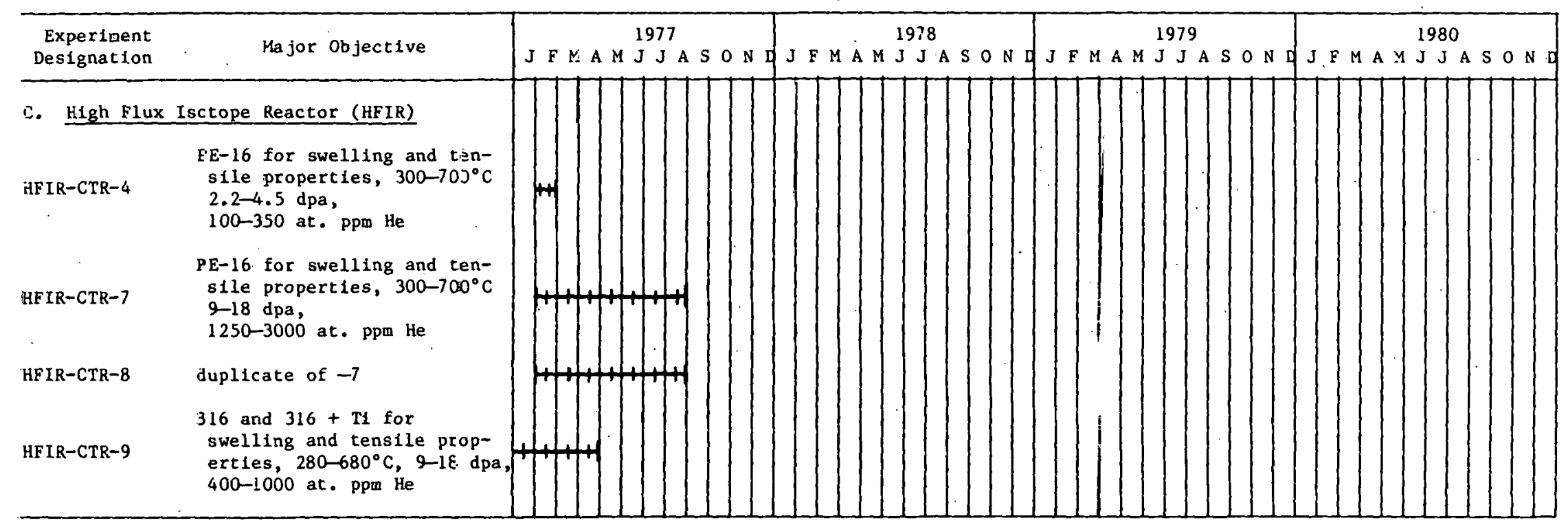




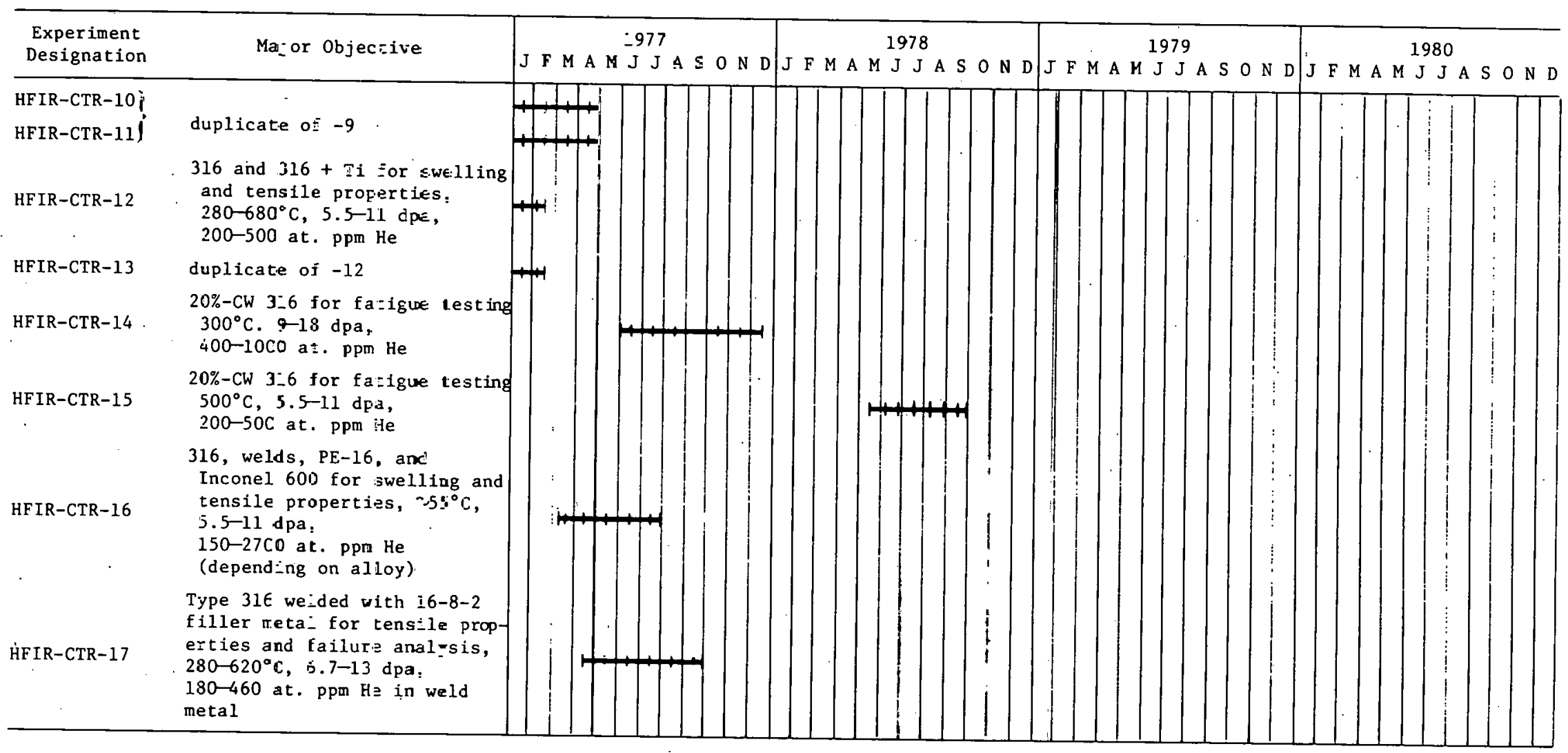




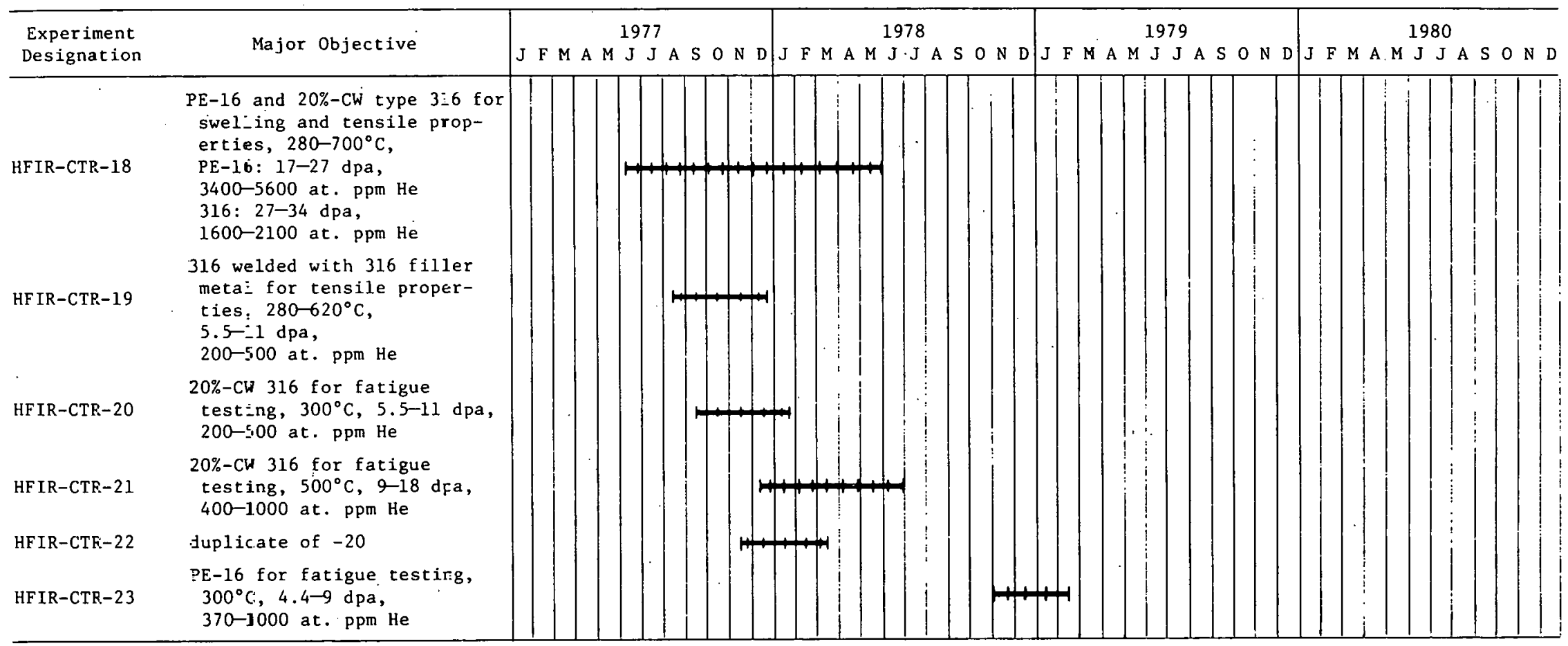




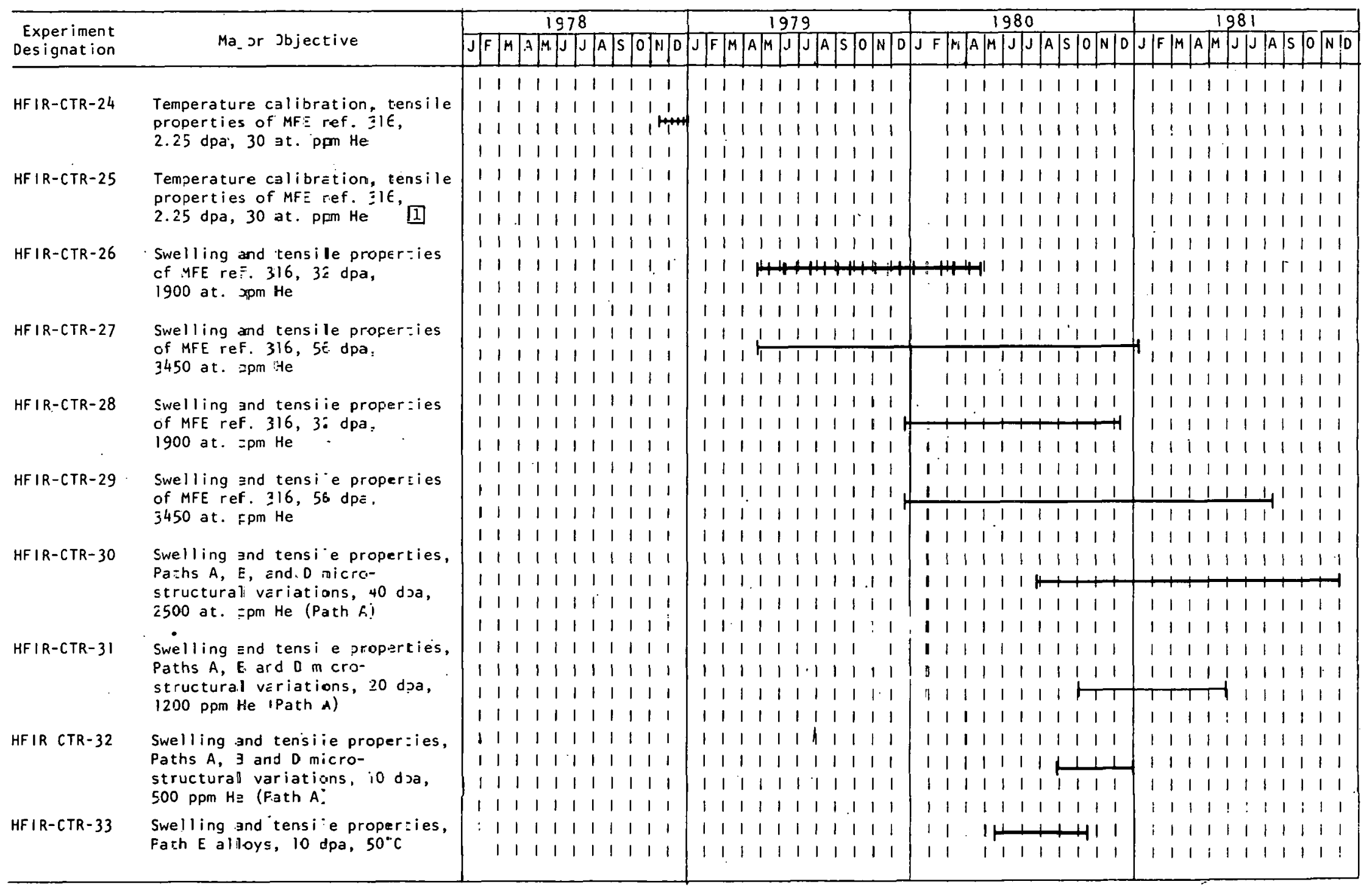

1 Delayed for undetemined period. 
8.2 ETM RESEARCH MATERIALS INVENTORY - F. W. Wiffen, T. K. Roche (ORNL) and J. W. Davis (McDonnell Douglas)

\subsubsection{ADIP Task}

ADIP Task I.D.1, Materials Stockpile for MFE Programs.

\subsubsection{Objective}

The Office of Fusion Energy has assigned program responsibility to ORNL for the establishment and operation of a central inventory of research materials to be used in the Fusion Reactor Materials research and development prograns. The objective is to provide a common supply of material for the Fusion Reactor Materials Program. This will minimize unintended materials variables and provide for economy in procurement and for centralized recordkeeping. Initially this inventory will focus on materials related to first-wall and structural applications and related research, but various special purpose materials may be added in the future.

The use of materials from this inventory for research that is coordinated with or otherwise related technically to the Fusion Reactor Materials Program of DOE, but which is not an integral or directly funded part of it, is encouraged.

\subsubsection{Materials Requests and Release}

Materials requests shall be directed to ETM Research Materials Inventory at ORNL (Attention: F. W. Wiffen). Materials will be released directly if:

(a) The material is to be. used for prugrams funded by the office of Fusion Energy, with goals consistent with the approved Materials Program Plans of the Materials and Radiation Effects Branch.

(b) The requested amount of material is available, without compromising other intended uses.

Materials requests that do not satisfy both (a) and (b) will be discussed with the staff of the Materfals and Radiation Effects Branch, Office of Fusion Energy, for agreement on action. 


\subsubsection{Records}

Composition and materials preparation records are maintained for all inventory material. All materials supplied to program users will be accompanied by summary characterization information.

\subsubsection{Summary of Current Inventory and Material Movement in Period July 1 to Sept. 30,1980}

A condensed, qualitative description of the content of materials in the ETM Research Materials Inventory is given in Table 8.2.1. This table. indicates the nominal diameter of rod or thickness of sheet for product forms of each alloy and also indicates by weight the amount of each alloy in larger sizes available for fabrication to produce other product forms as needer hy the program. Table 8.2.2 updates the inventory of available titanium alloys in more detail. There was no significant movement of materials in this reporting period.

Alloy compositions and more detail on the alloys and their procurement and/or fabrication are given in earlier ADIP quarterly progress reports. 
Table 8.2.1 Summary Status of Material Availability in the ETM Research Materials Inventory

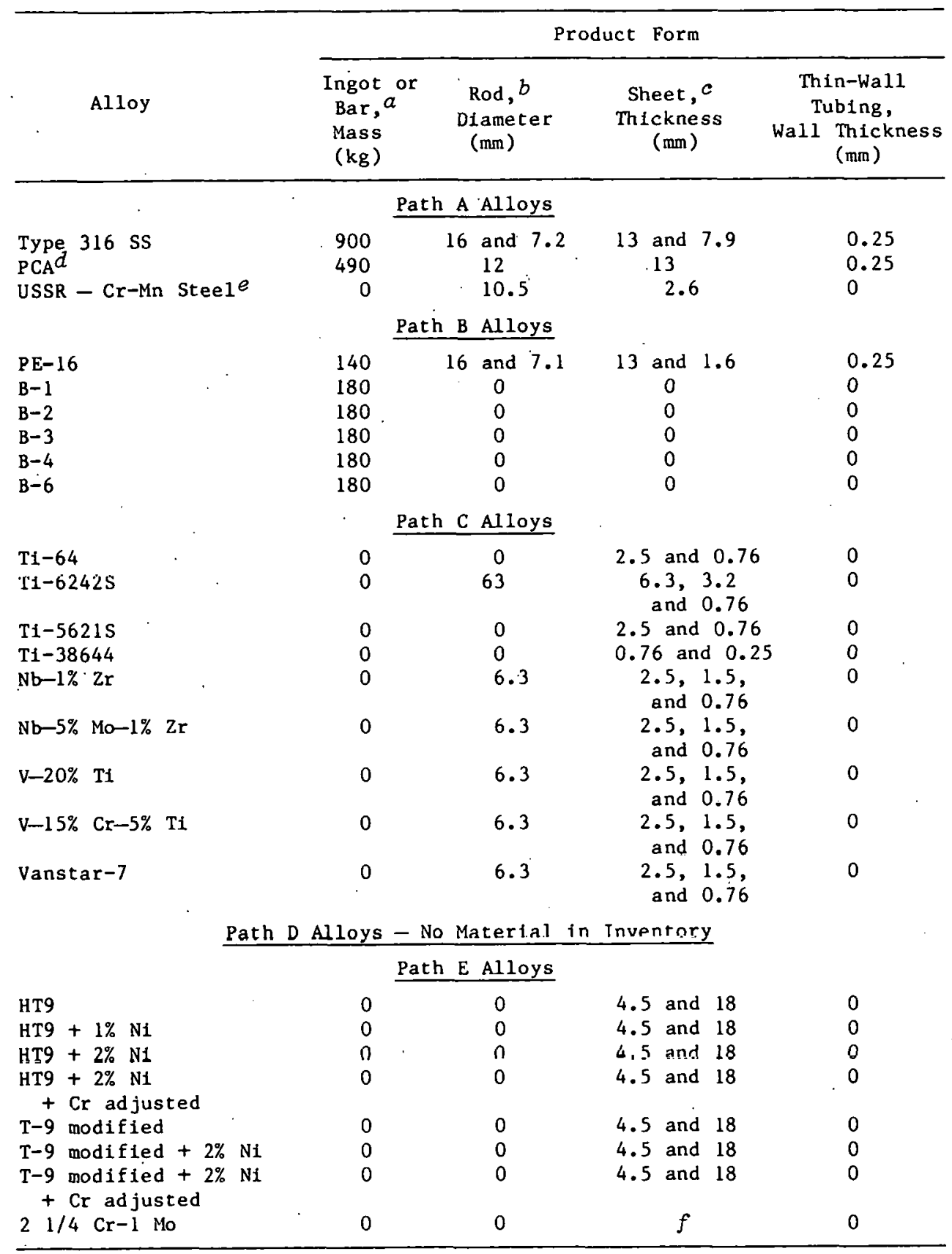

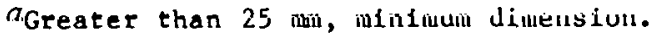

$b_{\text {Less than }} 25 \mathrm{~mm}$ in diameter. Some Path $\mathrm{A}$ and Path B alloys are avallable in two different diametero.

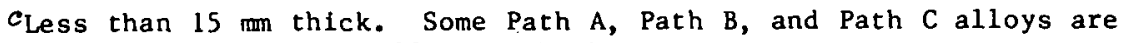
available in two or three different thicknesses.

dPrime Candidate Alloy.

$e_{\text {Rod }}$ and sheet of a USSR stainless steel supplied under the U.S.-USSR Fusion Reactor Materials Exchange Program.

Platerial is thlek-wall plpe, ierulled as tlecessary to produce sheet or rod. 
Tatle 3.2.2. Titazium Alloys Held at NcDonnell Douglas for the ETM Researsh Materials Inventory

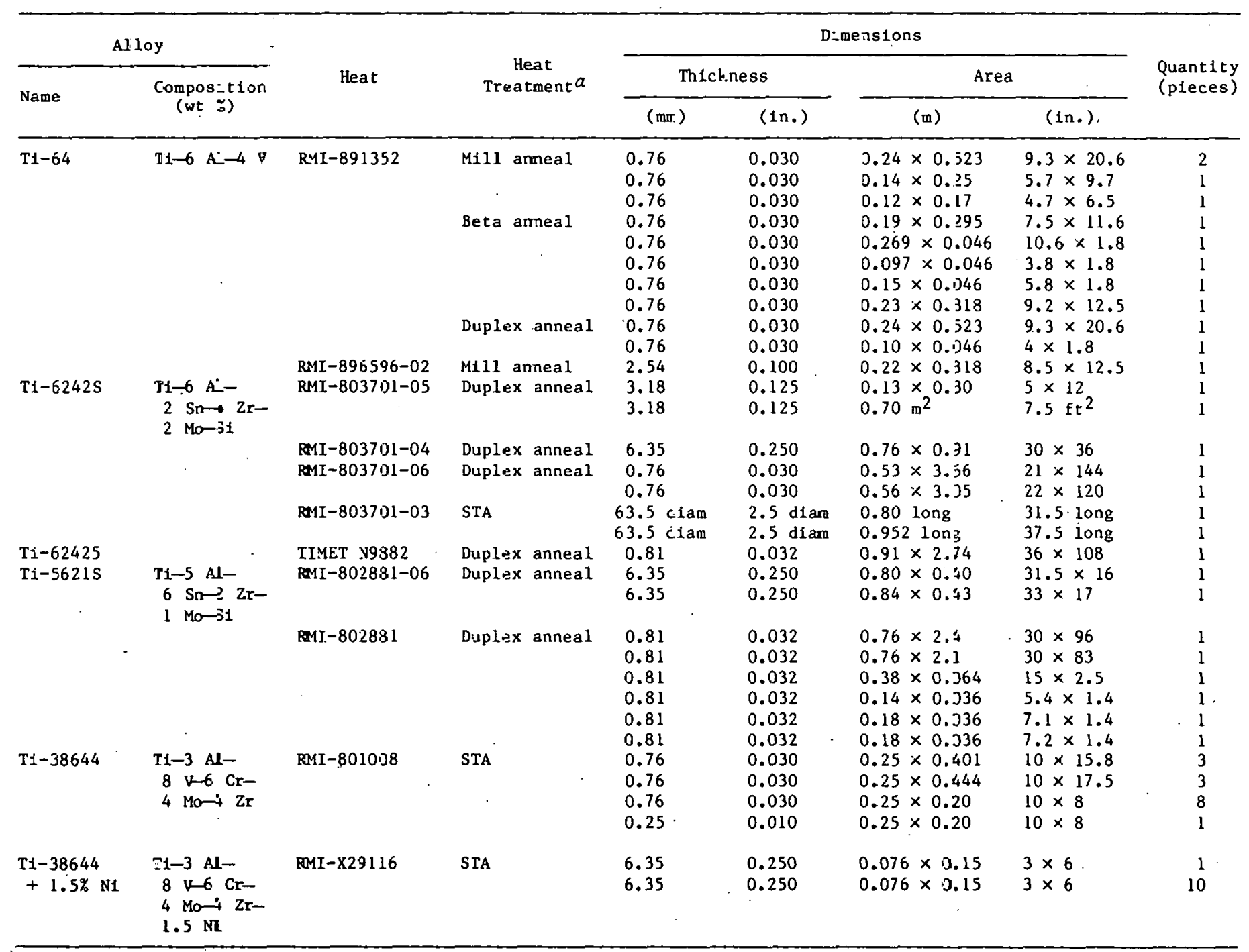

$a_{\text {STA }}=$ solution treated and aged.

$b_{A Z 1}$ are sheet except for heat RMI-303701-J3 of alloy T1-62425, which is rod. 
9. MATERIALS COMPATIBILITY AND HYDROGEN PERMEATION STUDIES 
9.1 HYDROGEN DISSOLUTION AND PERMEATION STUDIES OF ADIP PROGRAM ALLOYS.

-E. H. Van Deventer and V. A. Maroni (Argonne National Laboratory)

\subsubsection{ADIP Task}

I.A.4 Hydrogen Dissolution and Permeation Effects. The results presented in this section contribute to Subtask 1.A.4., Milestones I.A.a through I.A.d.

\subsubsection{Objectives}

The objcctive of the work reported in this section is to provite base-1ine hydrogen dissolution and permeation data for alloys currently under study in the ADIP Program. Information on hydrogen dissolution, outgassing and permeation characteristics of these materials is vital to an understanding of their performance as first-wall and blanket structural materials for fusion devices. A further objective of this work is to examine methods for overcoming any serious hydrogen isotope uptake and migration problems associated with the rather strong hydride-forming nature of some classes of alloys.

\subsubsection{Summary}

Studies of the hydrogen permeation characteristics of iron base (Path E) alloys have continued. An investigation of a $\mathrm{Cr}$ 14-A1 0.2 steel (405-SS) was completed and the measurements were compared to previous data for three other $\mathrm{Fe}-\mathrm{Cr}$ alloys having 0,2 , and 5 wt.\% $\mathrm{Al}$, respectively. The combined results indicate that the optimum aluminum content leading to minimum hydrogen permeability in a reducing environment is around $2 \mathrm{wt} . \%$. However, the chromium content of alloys studied to date has only spanned the range from 14 to $18 \mathrm{wt} . \%$, and the location of an optimum at $2 \mathrm{wt} . \%$ aluminum may not necessarily apply to other types of. Path E alloys.

\subsubsection{Progress and Status}

This section contains a report of work done during the third and fourth quarters of FY 1980 on the hydrogen dissolution and permeation 
characteristics of ADIP Program alloys. Also, in the same period some of the effort normally applied to this task was diverted to a newly initiated study of the corrosivity of solid ceramic breeder materials towards ADIP-specific alloys. The results of work on this new initiative are reported in section 9.5.

\subsubsection{Path A Alloys}

No report for this period.

\subsubsection{Path B Alloys}

No report for this period.

\subsubsection{Path C Alloys \\ No report for this period.}

9.1.4.4 Path D. Alloys

No report for this period.

\subsubsection{Path E Alloys}

(Work reported in this subsection was initiated during the first quarter of FY 1980, in conjunction with the start of the ADIP Program activity to evaluate ferritic materials for use as fusion reactor construction materials. The impetus for the study of fcrritic alloys as fusion reactor structural materials was discussed in a previous progress report.1)

Gulded by information derived from a survey ${ }^{2}$ of the reported hydrogen permeation characteristics of iron-base alloys, efforts on this task have continued to elucidate the effects of aluminum and chromium on the permeation resistance of selected $\mathrm{Fe}-\mathrm{Cr}-\mathrm{Al}$ alloys in a reducing (i.e., very low oxygen potential) environment. Since (1) only the aluminumcontaining iron alloys have shown any pronounced tendancy towards reduced permeability (i.e., a $>10^{2}$ reduction in permeability relative to pure iron) in reducing environments ${ }^{2}$ and (2) the magnitude of the reduction does not necessarily increase with increasing aluminum content 
of the alloy ${ }^{3}$, studies are being conducted to determine the optimum aluminum content (for maximum permeation resistance) and its relationship (if any) to the chromium content of the alloy. Previous work ${ }^{3}$ showed that a Cr 15-Al 5 alloy had a higher permeability than a $\operatorname{Cr} 18-\mathrm{Al} 2$ alloy. Pursuant to that work, an investigation has been made of the permeation characteristics of a $\mathrm{Cr} 14-\mathrm{Al} 0.2$ alloy (405-SS) to further refine the range of optimum aluminum content.

The hydrogen permeability of the 405-SS was measured between 180 and $700^{\circ} \mathrm{C}$ using $\mathrm{H}_{2}$ driving pressures in the range trom 103 to $15 \mathrm{kPd}$. This material exhibited the same type of data scatter observed previously for Fecralloy ${ }^{3}$ and Armco $18-\mathrm{SR}^{4}$. The range of permeation values recorded for the 405-SS is shown in Fig. Y.1.1 together with the prevluusly measured ranges for Fecralloy ( $\mathrm{Cr} 16-\mathrm{Al} 5$ ), Armcu 18-SR ( $\mathrm{Cr} 18-\mathrm{Al} 2$ ), and 430-SS ( $\mathrm{Cr}$ 16-Al 0). The permeation curve for "pure" iron is also included for comparison purposes. Armco 18-SR ( $\mathrm{Cr} 18-\mathrm{Al} 2$ ) shows the greatest reduction relative to "pure" iron, indicating that the optimum aluminum content may lie close to $2 \mathrm{wt} . \%$ for the higher chromium ferritic steels; however, studies of some 1 and 3 wt.\% Al alloys should be conducted to provide a further verification of this finding.

In other work related to Path E alloys, an HT-9 hydrogen permeation assembly was prepared using the gasket-sealing technique developed during earlier studies ${ }^{5}$ of titanium-base alloys. Attempts at using electron-beam welding methods to seal the HT-9 to stainless steel assembly couplings were unsuccessful, in that extremely brittle welds were formed which cracked during heat-up of the permeation assembly. The gasket-sealed HT- 9 assembly will be instailed and operated In the permeation apparatus during the first quarter of FY-1981.

\subsubsection{Refractories and Ceramics}

Several attempts have been made to develop a sultable methud for measuring the hydrogen permeability of ceramic and other brittle refractory materials (e.g, sapphire and tungsten). A technique based on deposition of gold bonding layers to Lhe edges of thin circular plates of the refractory/ceramic material is presently being explored. An 


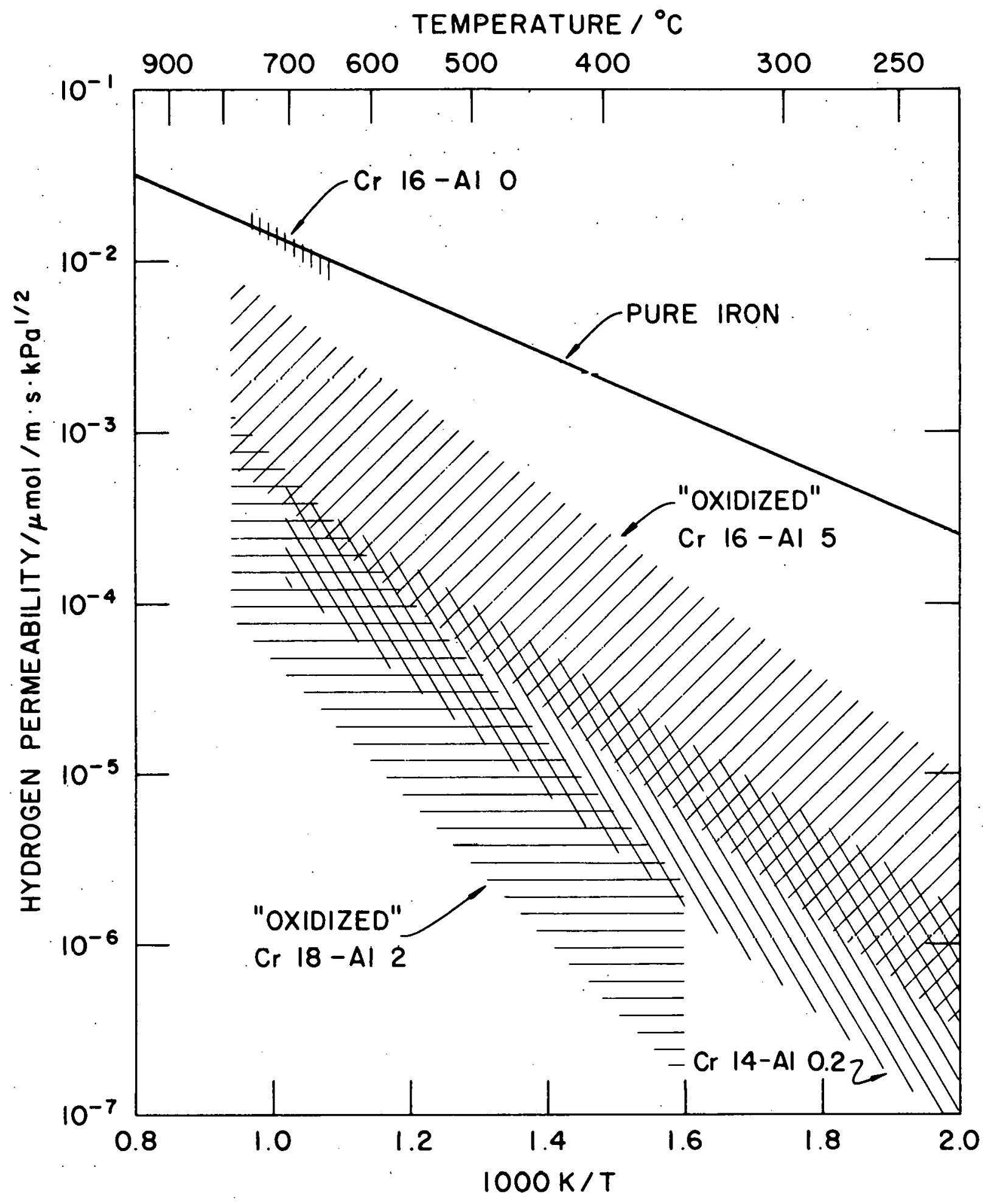

Fig. 9.1.1 Hydrogen Permeabilities of Selected Fe-Cr-Al Alloys in Comparison with Pure Iron. 
attempted application of the gasket-seal method ${ }^{5}$ to sapphire was unsuccessful. This study is being pursued to resolve discrepancies in (1) the pressure dependance of hydrogen permeation through ceramics and (2) the reported value of the hydrogen permeability of pure tungsten.

\subsubsection{Conclusions}

The optimum aluminum content of $\mathrm{Fe}-\mathrm{Cr}-\mathrm{Al}$ alloys from the standpoint of minimum hydrogen permeability in a reducing environment appears to be around 2 wt.\%.

\section{1 .6 References}

1. For a review, refer to Chapter 7 of Alloy Development for Irradiation Porformanco Ouarterly Hrogress Report for the Period Ending December 31, 17979, U.S. Department of Energy Report DOE/ET-0045/1, pp. 81-118 (1980).

2. E. H. Van Deventer, A. G. Rogers, and V. A. Maroni, "Hydrogen Dissolution and Permeation Studies of ADIP Program Alloys," ALloy Development for Irradiation Performance Quarteriy Progress Report for the Period Ending December 31, 1979, U.S. Department of Enèrgy Report DOE/ET-0045/1, pp. 140-147 (1980).

3. E. H. Van Deventer and V. A. Maroni, "Hydrogen Dissolution and Permeation Studies of ADIP Program Alloys," Alloy Developmert fur" Irradiation Performance Quarterly Progress Report for the Period. Ending March 31, 1980, U.S. Department of Energy Report DOE/ET 0045/2, pp. 200-205 (1980).

4. E. H. Van Deventer, V. A. Maclarell, and V. A. Maconi, "Hydrogen Permeation Characteristics of Aluminum-Coated and AluminumModified Steels," J. Nucl. Mater. 88: 168-173 (1980).

5. E. H. Van Deventer and V. A. Maroni, "Hydrogen Permeation Characteristics of Path A, Fath B, and Path C Alloys, Alloy Development for Irradiation Performarce quarterly Progress Report for the Period Ending Jurle 30, 1978, U.S. Department of Energy Report DOE/ET-00J8/2, pP. 169-174 (1979). 
9.2 VANADIUM ALLOY/LITHIUM PUMPED-LOOP STÚDIES-D. L. Smith, R. H. Lee, and R. M. Yonco (Argonne. National Laboratory)

\subsubsection{ADIP Task}

I.A.3. Chemical and Metallurgical Compatibility Analysis. The results presented in this section contribute to Subtask I.A.3.4, Milestones I.A.3.C and I.A.3.d.

\subsubsection{Objective}

The objective of this work is to develop preliminary data on the compatibility of candidate Path $\mathrm{C}$ alloys exposed to a flowing lithium environment. The major effort involves investigations of nonmetallic element interactions in reactive/refractory metal-lithium systems and the effects of lithium exposure on the mechanical properties of refractory metal alloys. Information relating to atmospheric contamination of reactive/refractory metal alloys will also be generated. Specific near-term experiments include measurements of the distribution of nonmetallic elements between selected refractory metals and lithium. The results of this work will contribute to the data base that relates compatibility and corrosion phenomena to other alloy development activities and will provide a basis for selecting candidate. Path $\mathrm{C}$ alloys for further development.

\section{2 .3 Summary}

The stainless-steel-clad/V-15 Cr lithium loop has now operated for over $12,000 \mathrm{~h}$ and exposures of selected refractory alloys have continued. The DOE/Office of Fusion Energy guidance on this project for FY-1981 has been to defer effort to solid breeder material development artivities. The work presently in progress is being completed and a final reporting of results will be made in a subsequent ADIP progress report. 
9.3 COAPATibility OF STATIC Lithium With Fe-Ni-V AND Fe-Cr-Mo ALLOYS P. F. Tortorelli, J. H. DeVan, and C. T. Liu (ORNL)

9.3 .1 ADIP Task

ADIP Task I.A.3, Perform Chemical and Metallurgical Compatibility Analyses.

\subsubsection{Objective}

The purpose of this program is to determine the chemical compatibility of fusion reactor candidate materials with metallic lithium. Specimens are exposed to static lithium containing selected solute additions to identify the kinetics and mechanisms that govern corrosion by lithium. Specific program objectives are: (1) to determine the effects of $\mathrm{N}, \mathrm{C}, \mathrm{H}$, and $\mathrm{O}$ on apparent solubilities of metals in lithium; (2) to determine the carbon and nitrogen partitioning coefficients between alloys and lithium; (3) to determine the effects of soluble ( $\mathrm{Ca}, \mathrm{Al}$ ) and solid ( $\mathrm{Y}, \mathrm{Zr}$, Ti) active metal additions on corrosion by lithium; and (4) to determine the tendencies for mass transfer between dissimilar metals in lithium.

\subsubsection{Summary}

Specimens of $21 / 4 \mathrm{Cr}-1 \mathrm{Mo}$ steel, HT9, and the long-range-ordered (LRO) alloy $\mathrm{Fe}-31.8 \mathrm{Ni}-22.5 \mathrm{~V}-0.4 \mathrm{Ti}$. (wt \%) were tested in static lithium, Carbon analysis of the lithium after 3000-h tests of $21 / 4 \mathrm{Cr}-1$ Mo steel showed significant decarburization of the steel at 500 and $600^{\circ} \mathrm{C}$. The decarburization lowered the room temperature tensile strength of the alloy: Specimens of $21 / 4 \mathrm{Cr}-1$ loo steel exposed to $\mathrm{Li}-5$ wt $\%$ Al showed significant weight gains with an accompanying decrease in ductility. Also, the gage section of fractured tensile specimens contained a olgniflcane volume of cracks. Short-term (500-h) exposures of HT9 to static $500^{\circ} \mathrm{C}$ lithium resulted in negligible weight changes and no change in its tensile properties relative to specimens exposed to argon under otherwise similar conditions. Surface deposits on the corrosion-resistant LRO alloy after exposure to lithium at 650 and $710^{\circ} \mathrm{C}$ for $2000 \mathrm{~h}$ were pure vanadium or possibly a vanadium carbonitride. 


\subsubsection{Progress and Status}

In the preceding quarterly report, 1 we presented data showing significant decreases in the yield and ultimate tensile strengths of $21 / 4 \mathrm{Cr}-1$ Mo steel exposed for $3000 \mathrm{~h}$ to lithium at 500 and $600^{\circ} \mathrm{C}$. Since then, carbon analyses of the post-test lithium have confirmed that the steels decarburized during exposures to it. Table 9.3.1 lists the relative changes in strength and elongation of the $21 / 4 \mathrm{Cr}-1$ ito steel and the corresponding concentrations of carbon in the post-test lithium. The data in this table reveal a direct correlation between the anount of decarburization (that is, carbon lost to the lithium) and the magnitude of the relative change in tensile test paraneters. The carbon analyses also indicate that, as reported earlier for the $500-$ and 1000 -h tests, 1

Table 9.3.1. Relative Changes $a$ in Yield Strength, Ultimate Tensile Strength, and Elongation of $2 \cdot 1 / 4 \mathrm{Cr}-1$ i.to Exposed to

Static Lithium for $3000 \mathrm{~h}$ and Corresponding Carbon Concentrations in Post-Test Lithium

\begin{tabular}{cccccc}
\hline $\begin{array}{c}\text { Temperature } \\
\left({ }^{\circ} \mathrm{C}\right)\end{array}$ & $\begin{array}{c}\text { Heat } \\
\text { Treatment }\end{array}$ & $\begin{array}{c}\text { Relative Change, } \% \\
\text { Yield } \\
\text { Strength }\end{array}$ & $\begin{array}{c}\text { Ultimate } \\
\text { Tensile } \\
\text { Strength }\end{array}$ & Elongation & $\begin{array}{c}\text { Carbon } \\
\text { Concentration } \\
\text { in Lithium } \\
\text { (wt ppm) }\end{array}$ \\
\hline \multirow{2}{*}{400} & HT1 & -8 & +3 & +15 & 76 \\
& HT2 & +2 & 0 & -17 & 86 \\
500 & HT1 & -17 & -8 & -8 & 427 \\
& HT2 & 0 & 0 & 0 & 273 \\
600 & HT1 & -24 & -21 & +21 & 980 \\
& H'l2 & -53 & -32 & +27 & 1410 \\
\hline
\end{tabular}
conditions.

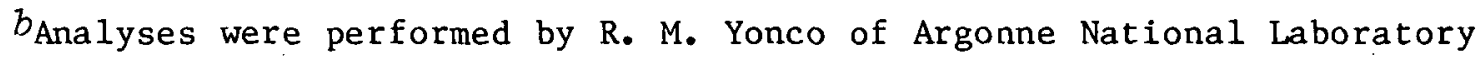
using the acetylene-evolution method, which measures the amount of carbon present as $\mathrm{Li}_{2} \mathrm{C}_{2}$ in the solid lithium. This method is described in E. M. Hobart and R. G. Bjork, "Validity of Determining Carbon in Lithium by Measurement of Aretylene Evolved on Hydrolysis," Anul. Chem. 39: 202 (1967). A control lithium sample was found to have a concentration of 3 wt $\mathrm{ppm}$.

$c_{\mathrm{HT} 1}=$ annealed; $\mathrm{HT} 2=$ normalized and tempered. $d_{\text {Filtered }}$ lithium samples were taken at respective test temperatures. 
the normalized and tempered steel lost less carbon at $500^{\circ} \mathrm{C}$ to the lithium than the $21 / 4 \mathrm{Cr}-1 \mathrm{Mo}$ steel that was simply annealed. However, it is also apparent from the present data that the situation is reversed at $600^{\circ} \mathrm{C}$ after $3000 \mathrm{~h}$ (which was the only exposure time used at this temperature), that is, at this temperature the normalized and tempered specimens were decarburized to a greater extent than the annealed ones. This change in the relative rates of decarburization between 500 and $600^{\circ} \mathrm{C}$ indicates differences in carbide chemistry and morphology between both the two heat, treatments and the two exposure temperatures.

We reported earlier 2,3 that the addition of aluminum to lithium resulted in the formation of a corrosion-resistant surface layer on type 316 stainless steel. As a first step in determining whether we could induce a similar corrosion ettect in lithium-ferrictc steel systems, 5 wt \% Al was added to lithium in $21 / 4 \mathrm{Cr}-1$ Mo steel capsules containing tensile specimens of the same composition and heat treatment as the capsule. Static tests at 500 and $600^{\circ} \mathrm{C}$ for 1000 and $3000 \mathrm{~h}$ have now been completed. The resulting weight changes are given in Table 9.3.2. For comparison, the table also includes data for $21 / 4 \mathrm{Cr}-1$ Mo steel in pure lithium and type 316 stainless steel in Li-5 wt \% Al. So far we have completed only a preliminary metallographic examination of the $21 / 4 \mathrm{Cr}-$ 1 lio steel specimens exposed to $\mathrm{Li}-5 \% \mathrm{Al}$. However, we have ind1rect evidence for an extended reaction between the aluminum and the steel from the data in Table 9.3.2. These show that the $21 / 4 \mathrm{Cr}-1$ lo specimens exposed to $\mathrm{Li}-5 \%$ Al gained a significant amount of weight relative to those specimens exposed to pure lithium. 'It is also interesting to note from Table 9.3.2 that the rate of weight gain of the $21 / 4 \mathrm{Cr}-1$ Mo steel in $\mathrm{Li}-5 \% \mathrm{Al}$ was greater than that of type 316 stainless steel exposed under similar conditions.

The introduction of aluminum into the near-surface regions of the $21 / 4 \mathrm{Cr}-1$ lo steel may adversely affect the material's mechanical properties. The data in Table 9.3 .3 show that $21 / 4 \mathrm{Cr}-1$ ho steel exposed to $\mathrm{Li}-5 \%$ Al significantly decreased in ductility (and, at $600^{\circ} \mathrm{C}$, in strength also) relative to tests conducted similarly in static argun and lithium. Figure 9.3.1 shows that the $21 / 4 \mathrm{Cr}-1$ Mo steel exposed 
Table 9.3.2. Weight Changes of $21 / 4 \mathrm{Cr}-1$ Mo Steel Exposed to Lithium and Type 316 Stainless Steel and $21 / 4 \mathrm{Cr}-1$ lo Steel Exposed to $\mathrm{Li}-5$ wt $\%$ Al

\begin{tabular}{|c|c|c|c|c|}
\hline Material & Environment $a$ & $\begin{array}{c}\text { Test } \\
\text { Temperature } \\
\left({ }^{\circ} \mathrm{C}\right)\end{array}$ & $\begin{array}{l}\text { Time } \\
\text { (h) }\end{array}$ & $\begin{array}{c}\text { Weight Change } b \\
\left(\mathrm{~g} / \mathrm{m}^{2}\right)\end{array}$ \\
\hline $21 / 4 \mathrm{Cr}-1$ ilo & $\mathrm{Li}$ & 500 & 1000 & $-0.9,-0.7$ \\
\hline $21 / 4 \mathrm{Cr}-1$ Mo & $\mathrm{Li}$ & 500 & 3000 & $-1.4,-1.4$ \\
\hline $21 / 4 \mathrm{Cr}-1 \mathrm{Mo}$ & $\mathrm{L} i-5 \quad \mathrm{Al}$ & 500 & 1000 & $+4.6,+5.1$ \\
\hline $21 / 4 \mathrm{Cr}-1$ Mo & $\mathrm{Li}-5 \mathrm{Al}$ & 500 & 3000 & $+6.8,+7.4$ \\
\hline Type 316 & $\mathrm{Li}-5 \mathrm{Al}$ & 500 & 2000 & +1.1 \\
\hline $21 / 4 \mathrm{Cr}-1 \mathrm{Mo}$ & $\mathrm{Li}$ & 600 & 3000 & $-2 \cdot 3,-2 \cdot 7$ \\
\hline $21 / 4 \mathrm{Cr}-1$ Mo & $\mathrm{Li}-5 \mathrm{~A} 1$ & 600 & 1000 & $+17.8,+21.5$ \\
\hline $21 / 4 \mathrm{Cr}-1 \mathrm{Mo}$ & $\mathrm{Li}-5 \quad \mathrm{Al}$ & 600 & 3000 & $+26.3,+32.0$ \\
\hline Type 316 & $\mathrm{Li}-5 \mathrm{Al}$ & 600 & 2000 & +6.5 \\
\hline
\end{tabular}

$a_{\text {Compositions are weight percent. }}$

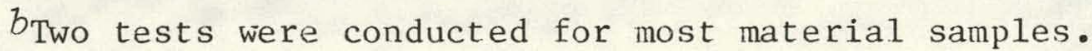

Table 9.3.3. Room Temperature Tensile Properties of $21 / 4 \mathrm{Cr}-1$ Mo Steel Exposed to Argon, Lithium, and Li-5 wt \% Al.

\begin{tabular}{|c|c|c|c|c|c|}
\hline Environment $a$ & $\begin{array}{l}\text { Test } \\
\text { Temperature } \\
\left({ }^{\circ} \mathrm{C}\right)\end{array}$ & $\begin{array}{l}\text { Time } \\
\text { (h) }\end{array}$ & $\begin{array}{l}\text { Yield } \\
\text { Strength } \\
\text { (MPa) }\end{array}$ & $\begin{array}{l}\text { Ultimate } \\
\text { Tensile } \\
\text { Strength } \\
\text { (MPa) }\end{array}$ & $\underset{(\%)}{\text { Elongation }}$ \\
\hline Ar & 500 & 1000 & 264.8 & 524.0 & 16.5 \\
\hline $\mathrm{Li}$ & 500 & 1000 & 237.2 & 493.7 & 15.3 \\
\hline $\mathrm{Li}$ & 500 & 1000 & 234.4 & 501.9 & 16.1 \\
\hline $\mathrm{Li}-5 \mathrm{Al}$ & 500 & 1000 & 295.1 & 449.5 & 11.3 \\
\hline Ar & 500 & 3000 & 264.8 & 521.2 & 16.4 \\
\hline $\mathrm{Li}$ & 500 & 3000 & 226.1 & 493.7 & 15.0 \\
\hline $\mathrm{Li}$ & 500 & 3000 & 212.4 & 463.3 & 15.2 \\
\hline $\mathrm{Li}-5 \mathrm{Al}$ & 500 & 3000 & 198.6 & 397.1 & 8.7 \\
\hline Ar & 600 & 3000 & 212.4 & 452.3 & 19.2 \\
\hline $\mathrm{Li}$ & 600 & 3000 & 157.2 & 350.3 & 23.0 \\
\hline $\mathrm{Li}$ & 600 & 3000 & 165.5 & 361.3 & 23.4 \\
\hline $\mathrm{Li}-5 \mathrm{Al}$ & 600 & 3000 & 129.6 & 311.6 & 8.5 \\
\hline
\end{tabular}

$a_{\text {Compositions are weight percent. }}$ 

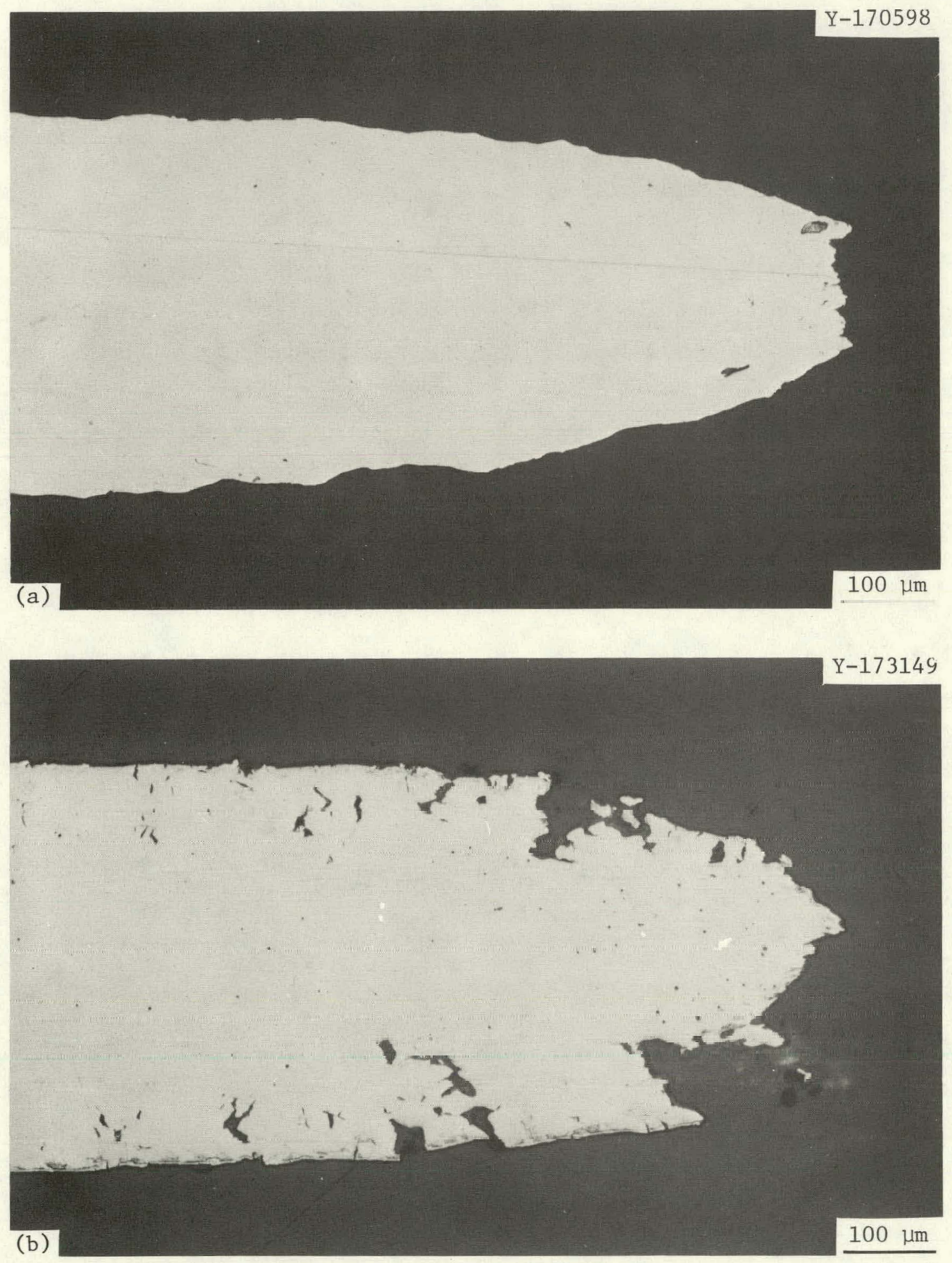

Fig. 9.3.1. Samples of $21 / 4 \mathrm{Cr}-1$ Mo Stee 1 Tensile Tested in Air at Room Temperature Following Exposure at $500^{\circ} \mathrm{C}$ for $1000 \mathrm{~h}$ in (a) Pure Lithium and (b) Li-5 wt \% Al. 
to $\mathrm{Li}-5 \% \mathrm{Al}$ for $1000 \mathrm{~h}$ cracked throughout the gage section during subsequent room temperature tensile testing, while the steel exposed to pure lithium for $1000 \mathrm{~h}$ showed only the primary gage section fracture. Additionally, examination of the tensile specimens exposed to argon revealed no significant cracking.

It is not clear whether aluminum diffusion into the $21 / 4 \mathrm{Cr}-1$ Mo steel or reaction of lithium with carbides in the steel reduces ductility after exposure to $\mathrm{Li}-5 \% \mathrm{Al}$. If the effect results from the aluminum layer restricting decarburization and thereby promoting attack of carbides by lithium, exposing already decarburized specimens under such conditions may avoid the cracking. Further experinents are planned to investigate this behavior in detail.

Another ferritic steel, HT9, containing 11.5 wt \% $\mathrm{Cr}$ and. 1 wt \% llo, was tested in static lithium. Our procedures for the HT9 capsule experiments are similar to those previously described ${ }^{4}$ for the $21 / 4 \mathrm{Cr}-1 \mathrm{Mo}$ tests: multiple tensile specimens of HT9 and either lithium or argon were sealed in capsules of similar composition and heat treatments for 500,1000 , and $3000 \mathrm{~h}$. A single exposure temperature of $500^{\circ} \mathrm{C}$ was used. The 500-h tests have now been completed and, as expected, specimen weights changed very little. The weight changes of normalized and tempered HT9 (three tests) and, for comparison, data reported earlier ${ }^{4}$ for $21 / 4 \mathrm{Cr}-$ 1 Mo steel (two tests) exposed to lithium for $500 \mathrm{~h}$ at $500^{\circ} \mathrm{C}$ are shown below:

$\begin{array}{ll}\text { Alloy } & \begin{array}{c}\text { Weight Changes } \\ \left(\mathrm{g} / \mathrm{m}^{2}\right)\end{array} \\ 21 / 4 \mathrm{Cr}-1 \text { Mo } & -0.2,-0.5\end{array}$

The weight changes are relatively small for both alloys, although the $21 / 4 \mathrm{Cr}-1$ Mo steel consistently lost weight, while the HT9 specimens gained in most cases. From this we assume that HT9; unlike $21 / 4 \mathrm{Cr}-1$ Mo ctcel, 1 was not decarburized by lithium, but we have not yet completed the carbon analysis of the post-test lithium. The tensile properties of the - HT9 samples exposed to lithium at $500^{\circ} \mathrm{C}$ for $500 \mathrm{~h}$ were not significantly different from those of the control HTg specimens held in argon at $500^{\circ} \mathrm{C}$ for the same time. 
It was shown earlier ${ }^{1,5}$ that an LRO alloy composed of $\mathrm{Fe}-31.8 \mathrm{Ni}-$ $22.5 \mathrm{~V}-0.4 \mathrm{Ti}$ (wt \%) was compatible with static lithium up to $30^{\circ} \mathrm{C}$ above its ordering temperature: after $2000 \mathrm{~h}$ exposure at 500,600,650, and $710^{\circ} \mathrm{C}$, weight changes were negligible. This contrasts with other higher nickel alloys, which were attacked significantly in static lithium. 5,6,7 We have recently completed an electron microprobe analysis of the LRO alloy specimens exposed to static lithium at 650 and $710^{\circ} \mathrm{C}$ [Figs. 9.3.2(a) and (b)]. The near-surface region was not depleted of any element, but small deposits on both surfaces were determined to be either pure vanadium or, since we could not detect light elements, a vanadium carbonitride. The radically different microstructure of the specinen exposed at $710^{\circ} \mathrm{C}$ results from signa phase formed by thermal aging during the cumpatibility test. We have no good explanation for these deposits at present. Such deposits normally result from precipitation from the lithium during cooling from the test temperature or from corrosionresistant nodules on the surface that are left behind as the surrounding areas are dissolved. However, the former pussibility is doubtful since a significant amount of vanadium should not dissolve in the lithiun; if, it had and then precipitated onto the surface, a vanadium concentration gradient in the near-surface region should be observed. Since no significant weight loss occurred, the latter factor is lul pussible cithcr. These surfaces will be charactertzed Curllel to possibly clarify the nature of the interaction.

\subsubsection{Conclusions}

1. Specimens of $21 / 4 \mathrm{Cr}-1$ Mo steel in lithium were significantly decarburized at 500 and $600^{\circ} \mathrm{C}$.

2. Specimens of $21 / 4 \mathrm{Cr}-1$ Mo steel reacted readily with Li-5\% Al at 500 and $600^{\circ} \mathrm{C}$, as evidenced by signifirant weight gains, but also exhibited decreased ductility. Cracking occurtad it the gags section of these specimens.

3. Short-term $(500-h)$ exposures of HT9 to static $500^{\circ} \mathrm{C}$ lithium resulted in negligible weight changes and no change in its room temperature tensile properties relative to specimens exposed to argon under otherwise similar conditions. 

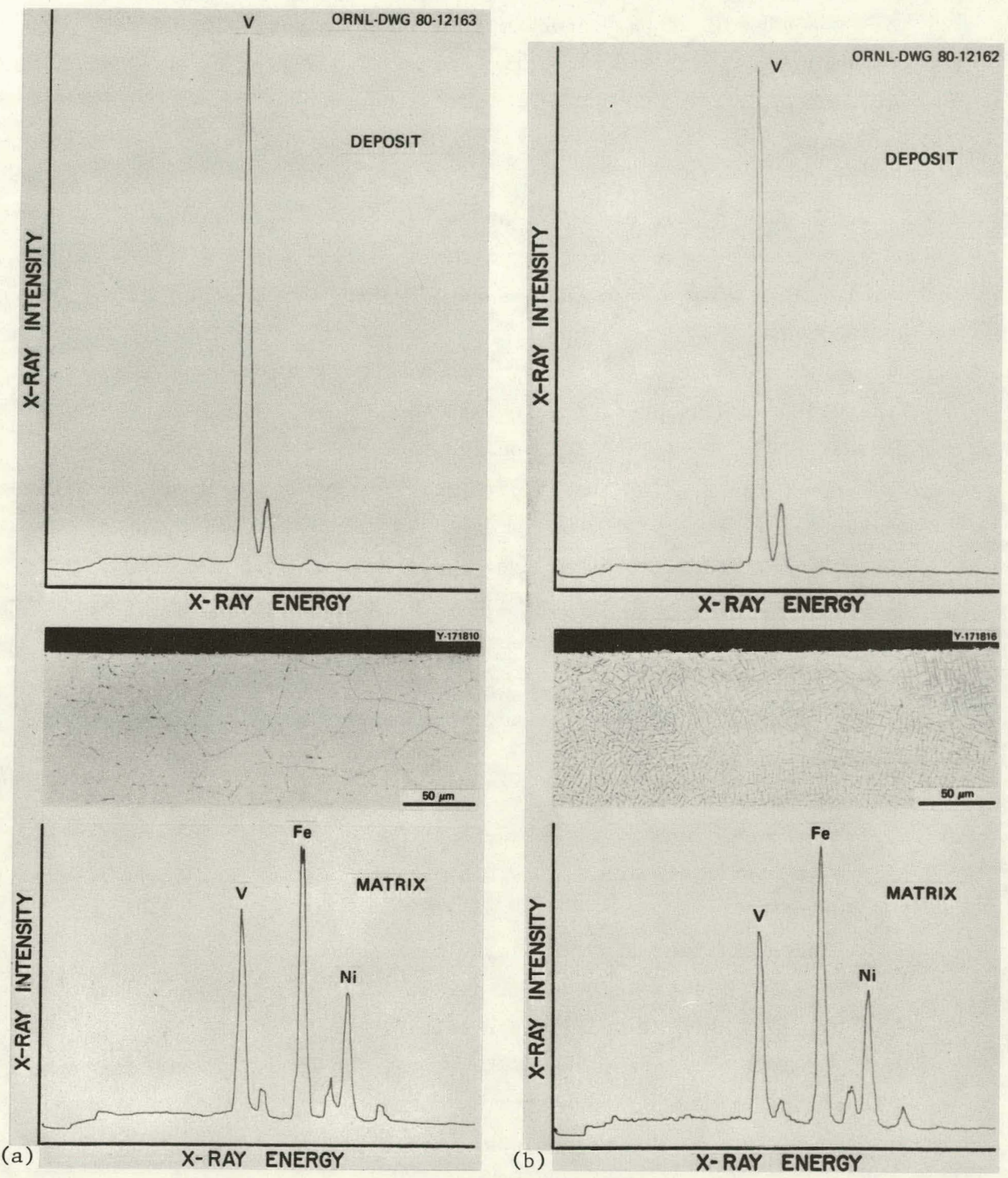

Fig. 9.3.2. The Long-Range-Ordered Alloy $\mathrm{Fe}-31.8 \mathrm{Ni}-0.4 \mathrm{Ti}$ (wt \%) Exposed to Static Lithium for $2000 \mathrm{~h}$ at (a) $650^{\circ} \mathrm{C}$ and (b) $710^{\circ} \mathrm{C}$. Results of the microprobe analysis of the deposit (above) and matrix (below) are also shown. 
4. Deposits of either vanadium or a vanadium carbonitride formed on the corrosion-resistant LRO alloy $\mathrm{Fe}-31.8 \mathrm{Ni}-22.5 \mathrm{~V}-0.4 \mathrm{Ti}$ (wt \%) at 650 and $710^{\circ} \mathrm{C}$ after $2000 \mathrm{~h}$ exposure to static lithium.

\subsubsection{References}

1. P. F. Tortorelli, J. H. DeVan, and C. T. Liu, "Compatibility of Static Lithium with a Long-Range-Ordered Fe-Ni-V Alloy and $21 / 4 \mathrm{Cr}-1 \mathrm{Mo}$ Stee1," ADIP Quart. Prog. Rep. June 30, 1980, DOE/ER-0045/3, pp. 328-36.

2. J. H. DeVau aud J. R. DiStefano, "Therma1-Convertinn tonop Tests of Type 316 Stainless Steel in Lithium," ADIP Quart. Prog. Rep. Mar. 31, 1978, DOE/E'I-UUb8/1, pp. 200-208.

3. P. F. Tertorelli, J. H. DeVan, J. E. Selle, and H. D. Upton, "Corrosion Inhibition in Systems of Lithium with Nicke1-Bearing Alloys," pp. 1610-13, Proc. 8th Symp. Eng. Prob. Fusion Res., IEEE Pubz. 79CH1441-5 NPS, C. K. McGregor and T. H. Batzer, eds., vo1. III, Institute of Electrical and Electronics Engineers, Inc., New York, 1979.

4. P. F. Tortore11i and J. H. DeVan, "Compatibility of $21 / 4 \mathrm{Cr}-1$ Mo Steel will Static Lithium," ADIP Quart. Prog. Rep. Mar. 31, 1980. DOE/ER-0045/2, pp. 213-18.

5. P. F. Tortorelli and J. H. DeVan, "Corrosion of Fe-Ni-Cr and Fe-Ni-V Alloys in Static Lithium," ADIP Quart. Prog. Rep. Dec. 31, 1979, DOE/ER-0045/1, pp. 152-57.

6. P. F. Tortorelli and J. H. DeVan, "The Corrosion of $\mathrm{Ni}-\mathrm{Fe}-\mathrm{Cr}$ and Cn-V-Fe (LRO) Alloys in Static Lithium," ADIP Quart. Proy. Rep. Mar. 31, 1979, DOE/ET-0058/5, pp. 141-47.

7. G. R. Edwards, D. Bates, and D. L. Olson, "An Evaluation of Engineering Alloys for High Temperature Lithium Containmetıl," paper 118 presented at NACE Corrosion/79, Atlanta, Ga., March 12-16, 1979. 
9.4 MASS. TRANSFER OF TYPE 316 STAINLESS STEEL IN LITHIUM. THERMALCONVECTION LOOPS - P. F. Tortorelli and J. H. DeVan (ORNL)

9.4.1 ADIP Task

ADIP Task I.A.3; Perform Chemical and Metallurgical Compatibility Analyses.

\subsubsection{Objective}

The purpose of this task is to evaluate the corrosion resistance of candidate first-wall materials to flowing lithium in the presence of a temperature gradient. Corrosion rates (in both dissolution and deposition) are measured as functions of time, temperature, additions to the lithium, and flow conditions. These measurements are combined with chemical and metallographic examinations of specimen surfaces to establish the mechanisms and rate-controlling processes for dissolution and deposition reactions.

\subsubsection{Summary}

The time dependence of metal dissolution in five type 316 stainless steel loop experiments in lithium is discussed. In general, the five sets of measurements were satisfactorily reproducible. The predicted dissolution rate of type 316 stainless steel at $600^{\circ} \mathrm{C}$ in lithium under conditions typical of semistagnant tritium-breeding blankets is less than $12 \mu \mathrm{m} /$ year (0.5 mil/year).

\subsubsection{Progress and Status}

We have continued our study of the mass transfer of type 316 stainless steel in flowing lithium using previously described thermalconvection loops (TCLs) with accessible specimens. These loops are designed so that lithium samples can be taken and corrosion coupons can be withdrawn and inserted wilhout altering the loop operating conditions. Three loops have operated under nearly identical temperature conditions to develop data on dissolution and deposition processes as a function of time.2,3 Plugging from mass transfer deposits necessitated replacement of 
the cold legs in all three loops after 5000 to $10,000 \mathrm{~h}$. Two of these loops have now completed more than $5000 \mathrm{~h}$ additional operation since new cold legs were installed. Fresh coupons were inserted into the refurbished loops and their weight changes have been monitored as a function of time. These data are included with those from the original three loops in Fig. 9.4.1. The data represent the maximun weight losses measured at any given time and were obtained from the coupon located at the maximum temperature position $\left(600^{\circ} \mathrm{C}\right)$ in each loop. Four of the data sets are plotted as the solid circles and fall within a small scatter band along the curve represented by the dashed line. Weight losses from one loop experiment, however, have been consistently less than those frum the otliex tests. These are shown as the open circles.

The lower weight losses in the latcer loop experimeil wert olitained after, replacement of a cold-leg section in a loop that had previously operated for $5000 \mathrm{~h}$. (Data for the previous period fell along the upper curve.) This pattern was not repeated in the second of the loops in which

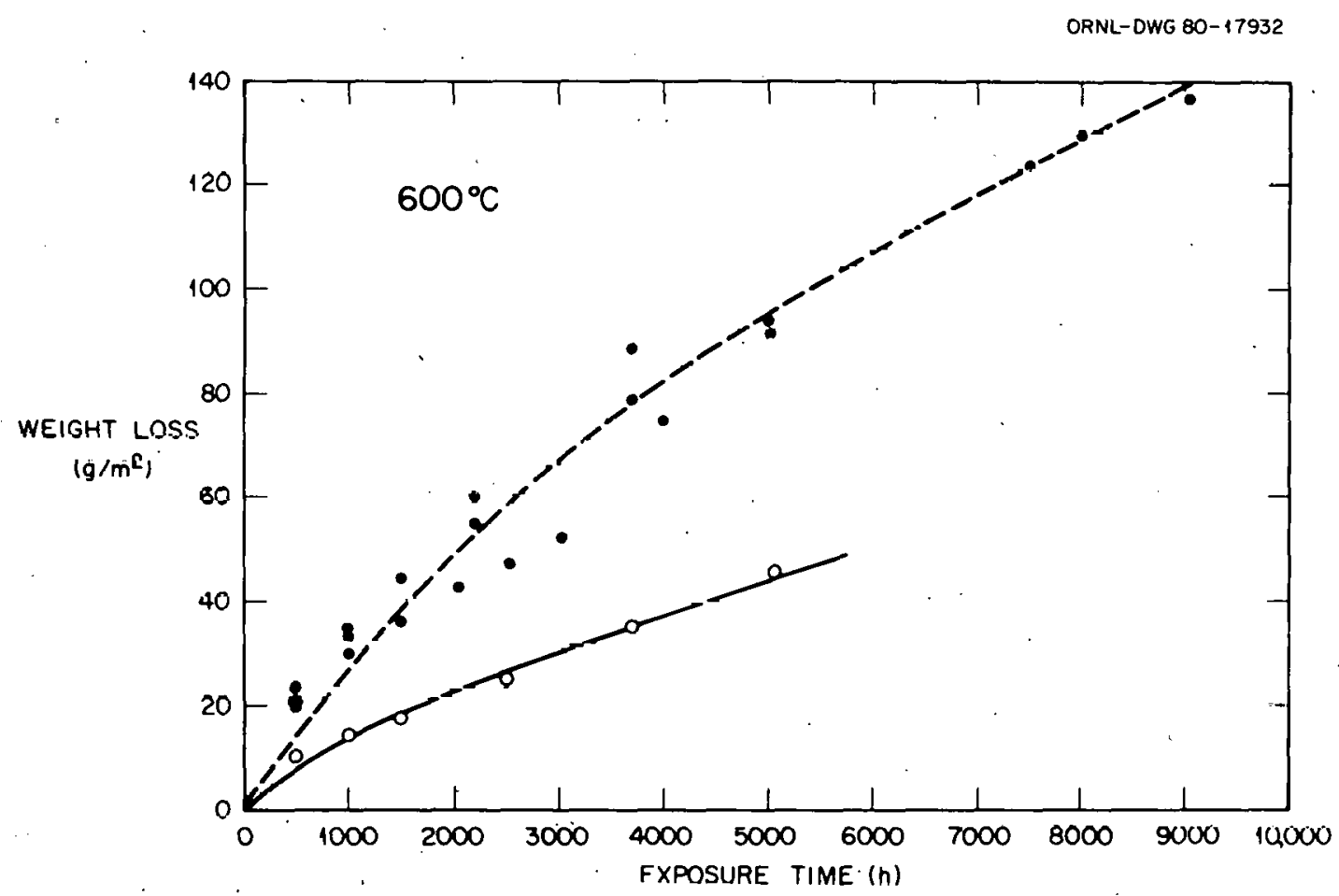

Fig. 9.4.1. Compilation of Weight Loss Data from Five LithiumType 316 Stainless Steel Thermal-Convection Loop Experiments. Solid circles = data from four of the experiments; open circles = data from fifth experiment. 
the cold-leg section was replaced. The weight losses versus time in this loop were about the same before and after replacement. Thus, the reason. for the lower weight loss data is unclear. We do not believe it is related to initial impurities in the lithium since analysis of the lithium in this loop during the first $1000 \mathrm{~h}$ of the experiment yielded oxygen and nitrogen concentrations that were about the same or just slightly greater than those measured for the lithium in the other loops. We will conduct a more extensive comparative analysis when the loop coupons have been exposed approximately $7500 \mathrm{~h}$. This will include metallographic examination of the loop specimens as well as chemical analyses of the lithium. However, it should also be noted that the discrepancy between the loop data represented by the solid circles in Fig. 9.4.1 and those of the fifth loop (open circles) is not as great as. it may seem from the figure. This is because the major values of interest, the dissolution rates. (which are derived from the slopes of the weight loss versus time curves), differ by a factor of less than 2; the longer term dissolution rate for the four loops represented by the dashed line is $10.5 \mathrm{mg} /\left(\mathrm{m}^{2} \cdot \mathrm{h}\right)$, while that for the Fifth loop experinent (solid line) is $6.3 \mathrm{mg} /\left(\mathrm{m}^{2} \cdot \mathrm{h}\right)$.

While the lithium velocity in our TCLs is low (approxinately $30 \mathrm{~mm} / \mathrm{s}$ ), it is about that of a semistagnant fusion reactor lithium blanket used for breeding tritium. We can therefore predict from the above data the expected corrosion rate in such a lithium system. At $600^{\circ} \mathrm{C}$, for pure lithium (oxygen and nitrogen concentrations less than 135 wt ppm, respectively), the dissolution rate should be less than $12 \mu \mathrm{m} /$ year ( $0.5 \mathrm{mil} /$ year). However, the conversion of the above mass corrosion rate (milligrams per meter squared per hour) to units of surface recession (micrometers per year) requires at least one caveat. As seen in Fig. 9.4.2, the near-surface layer of type 316 stainless steel at $600^{\circ} \mathrm{C}$ tends to be very porous after exposure to circulating lithium. Therefore, the surface recession rate (as calculated from specimen weight loss) does not reflect the total extent of surface attack. This surface layer, which has been preferentially depleted of nickel and chromium, appears to reach a limiting thickness and remain constant after approximately $3000 \mathrm{~h} .4$ Thus, the recession rate (as calculated from the specimen weight loss as a function of time), when added to the depth of the near-surface layer, provides a reasonable estimate of the extent of degradation in the loadbearing cross section of the steel. 


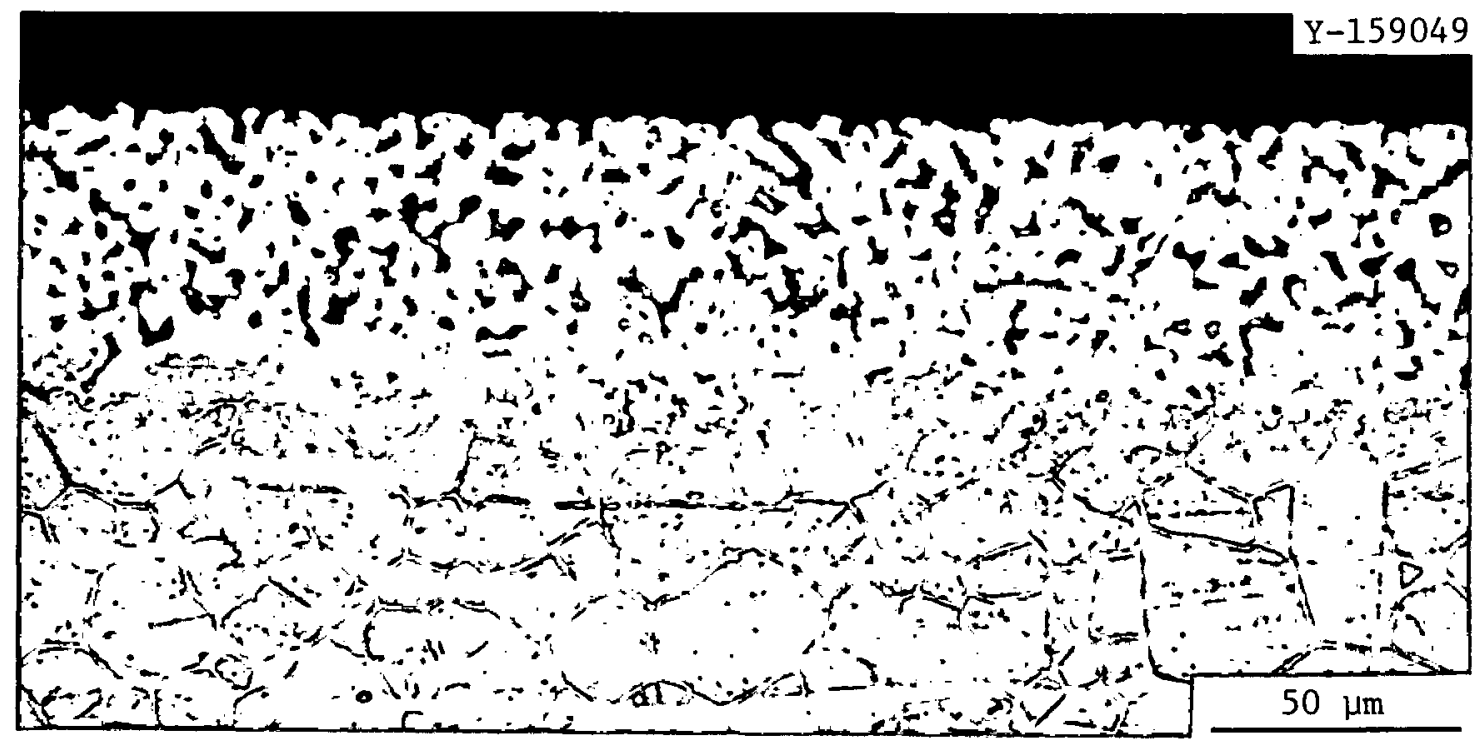

Fig. 9.4.2. Type 316 Stainless Steel Exposed to Lith1um In a Therma1-Convection Loop for $9000 \mathrm{~h}$ at $600^{\circ} \mathrm{C}$.

\subsubsection{Conclusion}

Weight loss data from five type 316 stainless steel TCL experiments indicate a low dissolution rate of this steel in slowly flowing lithium characteristic of semistagnant tritium-breeding blankets.

\subsubsection{References}

1. J. H. DeVan and I. K, Distefano, "Therma1-Convection Loop Tests of Type 316 Stainless Steel in Lithium," ADIP Quart. Prog. Rep. Mar. 31, 1978, DOE/ET-0058/1, pP. 200-08.

2. P. F. Tortorelli and .J. H. DeVan, "Thermal-Gradient Mass Transfer in I,ithium-Stainlese Steel Systems," et. Nuct. Mater. 85 \& bb(11, A): 289-93 (1979).

3. P. F. Tortorelli and J. H. DeVan, "Mass Transfer Deposits in LithiumType 316 Stainless Steel Thermal-Convection Loops," paper presented at Second International Conference on Liquid Meta1 Technology in Energy Production, Richland, Wash., April 21-24, 1980.

4. P. F. Tortorelli, J. H. DeVan, and J. E. Selle, "Corrosion in LithiumStainless Steel Thermal-Convection Systems," paper presenled at Second International Conference on Liquid Metal Technology in Energy Production, Richland, Wash., April 21-24, 1980. 
9.5 COMPATIBILITY OF SOLID CERAMIC BREEDER MATERIALS WITH ADIP PROGRAM

ALLOYS-S. R. Breon and P. A. Finn* (Argonne National Laboratory)

\subsubsection{ADIP Task}

I.A.3 Chemical and Metallurgical Compatibility Analysis. The results presented in this section contribute to Subtasks I.A.3.3 and I.A.3.4 and associated milestones. They also contribute to milestones relevant to Path E alloy development.

\subsubsection{Objectives}

The objective of the work reported in this section is to provide baseline data on the compatibility of candidate ceramic tritium breeder materials with ADIP Program alloys. Limitations associated with operating temperature, chemical impurities, alloy composition, and the formation of vapor phase species are investigated. The mechanisms of corrosive attack are identified and characterized and the results are used to develop a basis for the selection of optimum construction materials for solid breeder blankets.

\subsubsection{Summary}

An initial scoping experiment was carried out to investigate the interfacial compatibility of selected solid ceramic tritium breeder materials with typical ADIP Program alloys. Each of the solid breeder materials $\mathrm{Li}_{2} \mathrm{O}, \mathrm{LiAlO}_{2}$, and $\mathrm{Li}_{2} \mathrm{SiO}_{3}$ was exposed to 316-SS, HT-9, Inconel 625 , and $T i 6242$ at $873 \mathrm{~K}$ for $21900 \mathrm{~h}$ in a high purity helium environment using a reaction couple method. Examination of the alloy/ ceramic interfaces by SEM, Auger, and X-ray diffraction analysis revealed that reaction scales comprised of elements from both the alloy and ceramic had formed in all cases. These scales were thickest for the $\mathrm{Li}_{2} \mathrm{O} / \mathrm{alloy}$ reaction couples. Ternary phases of Lhe type $\mathrm{Li}_{x} \mathrm{M}_{\mathrm{y}} \mathrm{O}_{z}$ have been identified at most of the interfaces for which analyses have been completed. Analytical procedures and improved strategies for future ceramic breeder corrosion tests have been developed.

*Student aide from Pennsyivania State University. 


\subsubsection{Progress and Status}

This section describes work done to date to evaluate the corrosivity of solid ceramic breeder materials towards ADIP-specific alloys using the reaction couple method. Based on the data acquired in the first experiment, the reactions between the various ceramics and alloys are being examined qualitatively to determine the most promising materials combinations and technical approaches for subsequent corrosion tests.

\subsubsection{Experimental Procedure}

The solid breeder corrosion tests were conducted in a helium environment at $873 \mathrm{~K}$ for $21900 \mathrm{~h}$ with the samples ret.ained in a stainless steel tèst apparatus contigured as shown in Fig. 9.5.1. (An Inconel $X-750$ spring provided the compressive force that held the samples in place.) The test samples were characterized after exposure by means of photographic and visual examination, $X$-ray analysis, scanning electron microscopy, and Auger analysis.

The ceramics studied in this experiment were lithium oxide $\left(\mathrm{Li}_{2} \mathrm{O}\right)$, lithium silicate $\left(\mathrm{Li}_{2} \mathrm{SiO}_{3}\right)$, and gamma lithium aluminate $\left(\gamma-\mathrm{LiAlO}_{2}\right) \cdot \mathrm{Li}_{2} \mathrm{O}$ powder was purchased from Research Organic/Inorganic Chemical Co. Chemical analysis showed it to be $93.3 \%$ pure. The powder was pressed at $1.2 \mathrm{~T} / \mathrm{cm}^{2}$ and sintered at $1073 \mathrm{~K}$, then cut into square pellets about $15 \mathrm{~mm}$ on a side with thickness between 4.5 and $5.5 \mathrm{~mm}$. The pellets were $79 \%$ of theoretical density.

Glassy $\mathrm{Li}_{2} \mathrm{SiO}_{3}$ samples were obtained from McDonnell Douglas Astronautics Co. (MDAC, J. W. Davis). The samples were approximately $13 \mathrm{~mm}$ on a side, $3 \mathrm{~mm}$ thick, and $88 \%$ of theoretical density. $\mathrm{LiAlO}_{2}$ samples were prepared by R. M. Arons of the Materials Science Division of ANL. They were heat treated at $1383 \mathrm{~K}$ to form the gamma phase. The samples were appruxilld lely $12 \mathrm{~mm}$ on a side with a thrckness of $1.5 \mathrm{~mm}$ and the reported density was $59.1 \%$ of the theoretical density.

Specimen tabs of the four alloys tested in the first experiment-316 SS, Inconel 625, HT-9, and Ti6242--were prepared by A. G. Hins et al. of the ANL Materials Science Division (MSD). The composition of each alloy is given in Table 9.5.1. The alloys were marked with coded notches 


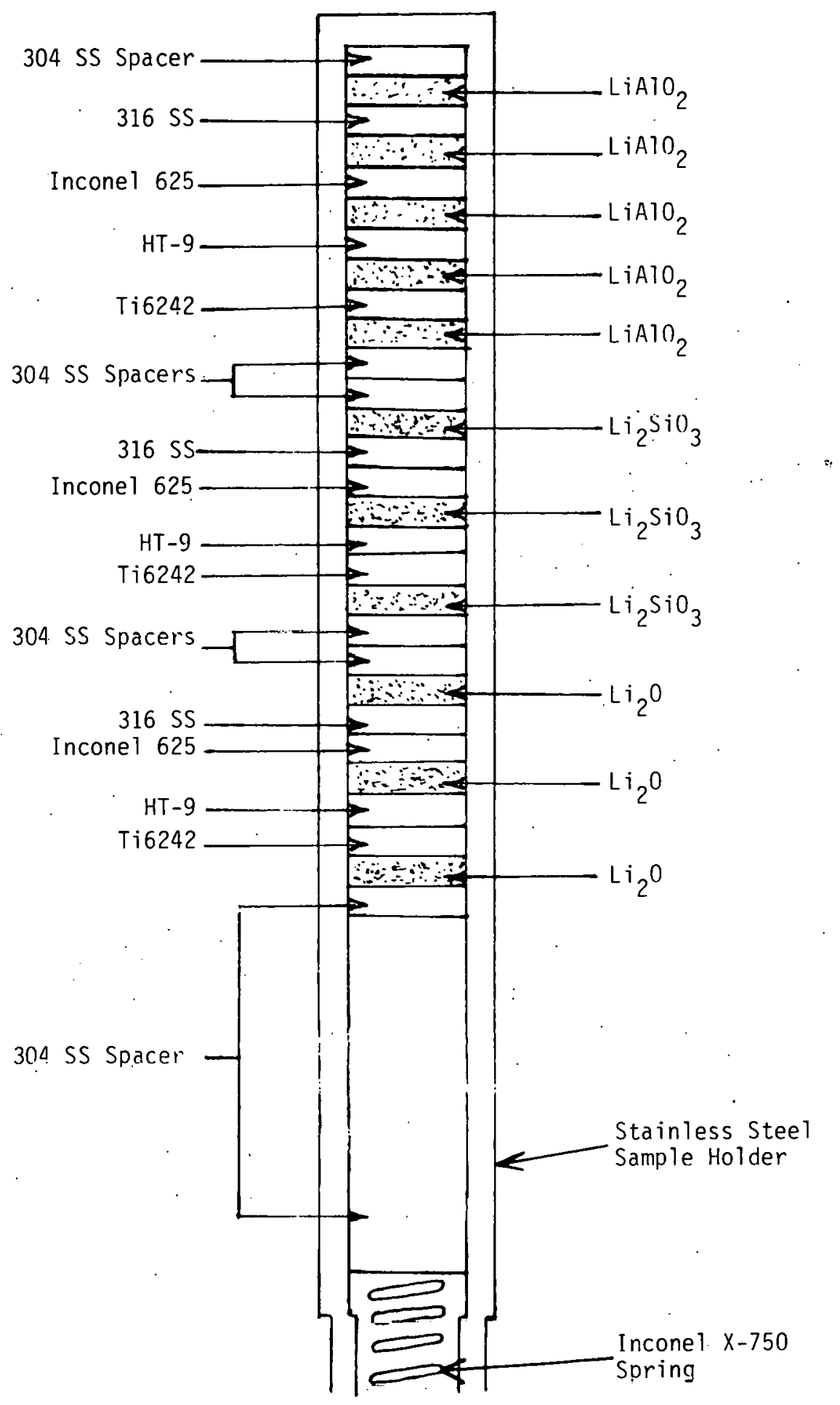

Fig. 9.5.1. Experimental Configuration Showing the Sample Stacking Order. 
Table 9.5.1. Alloy Compositions (Nominal), w/o

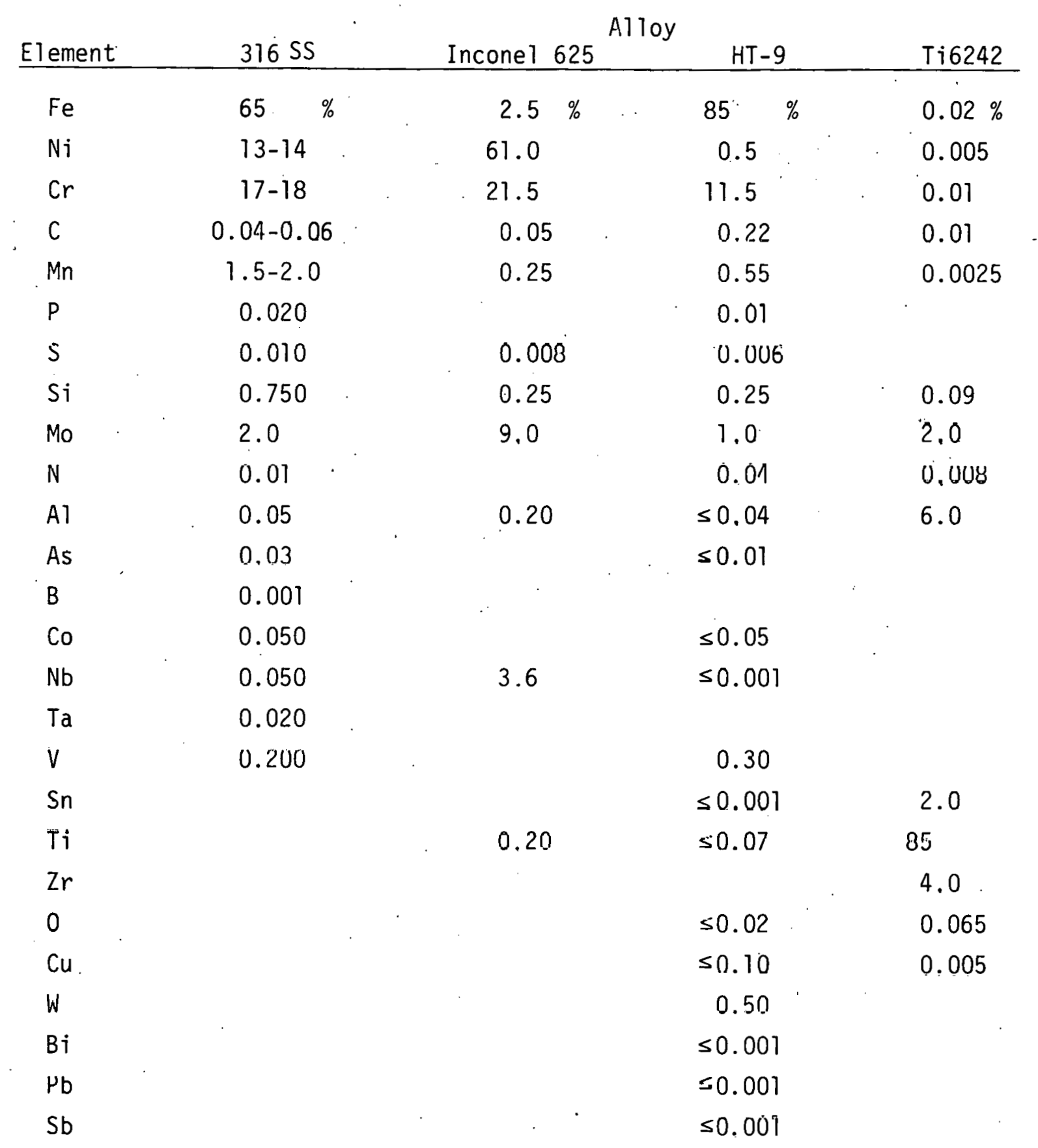


and holes for identification as to type and orientation. Each sample was $273 \mathrm{~mm}$ on a side with thickness between 0.8 and $1.4 \mathrm{~mm}$.

Photographs were taken of the apparatus before dismantling (e.g., see Fig. 9.5.2). Dismantling was done in an argon glovebox with care taken to preserve information on the orientation of each sample. Each sample was given a careful visual examination with particular interest paid to changes in color and surface texture; development of cracks, fractures, and fine scratches; and any other transformations which may have occurred. These results will be discussed in the next section. A complete photographic record was kept of all alloy samples. The ceramic samples were weighed and measured to determine changes in density--no significant changes were found.

In some cases, visual and photographic examination was augmented by use of X-ray analysis, scanning electron microscopy, and Auger analysis. From the data, a qualitative description of the compatibility of ceramic/alloy pairs was developed. This is summarized in Table 9.5.2.

\subsubsection{Results and Discussion}

The lithium aluminates were the least changed in appearance of any of the ceramics. The edges turned dark gray and black speckles appeared on the surfaces. The $\mathrm{LiAlO}_{2}$ sample in contact with the HT-9 sample adhered to the alloy and had to be gently pried loose with a spatula. A11 alloys except Ti6242 had gray images over the area in contact with the $\mathrm{LiAlO}_{2}$; the image on the $\mathrm{Ti} 6242$ was reddish-gray.

Significant changes were observed in the $\mathrm{Li}_{2} \mathrm{SiO}_{3}$ samples. Originally the samples were unannealed transparent glasses containing a few small cracks. After the test, all three samples became opaque and milky-white in color. In addition, yellow regions could be seen on the top and bottom faces indicating the possible formation of color centers due to interdiffusion of metallic elements from the adjacent alloys. The cracks increased in number and size, and the samples readily fractured into smaller pieces along these cracks. A 11 alloys but Ti6242 had gray surface images of the $\mathrm{Li}_{2} \mathrm{SiO}_{3}$ pellet. The entire $\mathrm{Ti} 6242$ sample took on a reddish tinge. 


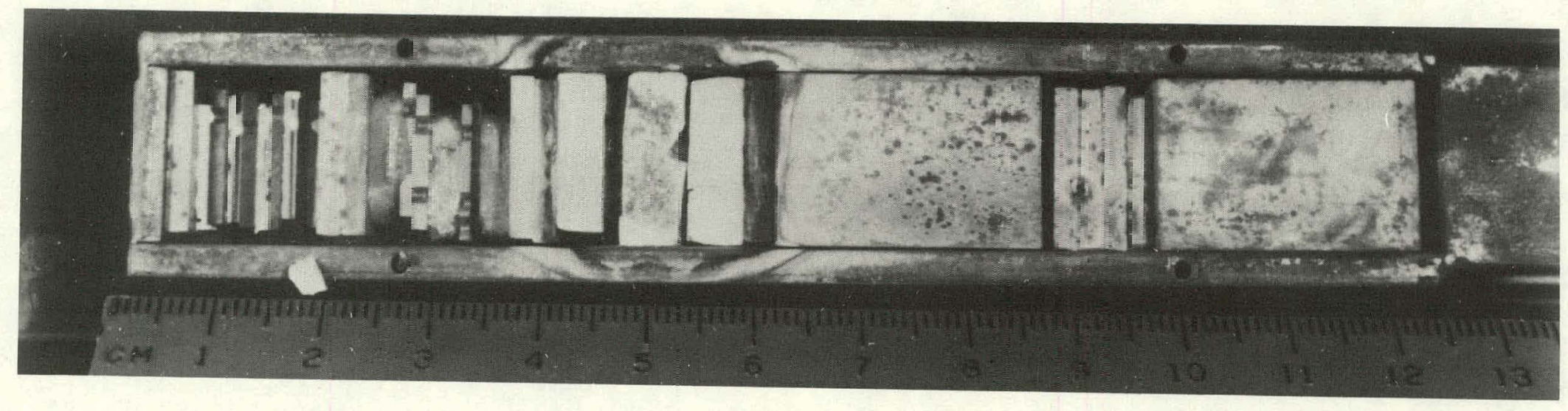

Fig. 9.5.2. Fhotograph of Corrosion Test Apfaratus After 1900 h at $873 \mathrm{~K}$. 
Table 9.5.2. Summary of Corrosion Data

\begin{tabular}{|c|c|c|c|c|c|c|}
\hline Ceramic & Alloy & $\begin{array}{c}\text { Visua } i \\
\text { Examinationa,b }\end{array}$ & $\overline{\text { Depth }}$ & $\frac{\mathrm{M}^{\mathrm{a}}}{\text { Elements }} \mathrm{g}-$ & $\begin{array}{c}\text { X-ray } \\
\text { Analysis }\end{array}$ & $\begin{array}{l}\text { Auger } \\
\text { Analysis }\end{array}$ \\
\hline \multirow{4}{*}{$\mathrm{Li}_{2} \mathrm{O}$} & $316 \mathrm{SS}$ & heavy ${ }^{c}$ & $\sim 4 \mu$ & $\mathrm{Fe}, \mathrm{Cr}, \mathrm{Ni}$ & $\mathrm{Li}_{5} \mathrm{FeO}_{4}$ & $\begin{array}{l}\mathrm{Li}, 0, \mathrm{Mo} \\
\mathrm{Fe}, \mathrm{Cr}(?)\end{array}$ \\
\hline & Inconel 625 & heavy & $\sim 4 \mu$ & $\mathrm{Ni}, \mathrm{Cr}, \mathrm{Fe}$ & $\mathrm{Li}_{2}^{\mathrm{Ni}}{ }_{8}^{\mathrm{Ni}}{ }_{10}$ & $\ldots f$ \\
\hline & HT-9 & heavy & $\sim 7 \mu$ & $\mathrm{Fe}, \mathrm{Cr}, \mathrm{Ni}$ & $\mathrm{Li}_{5} \mathrm{FeO}_{4}$ & $\ldots f$ \\
\hline & Ti6242 & moderate ${ }^{d}$ & $\sim 4 \mu$ & $\mathrm{Ti}, \mathrm{Fe}, \mathrm{Cr}, \mathrm{Ni}$ & $\ldots f$ & $\ldots f$ \\
\hline \multirow{4}{*}{$\mathrm{LiAlO}_{2}$} & $316 \mathrm{SS}$ & lighte. & $<2 \mu$ & $\mathrm{Fe}, \mathrm{Cr}, \mathrm{Ni}$ & & $\ldots f$ \\
\hline & Inconel 625 & light & $<2 \mu$ & $\mathrm{Fe}, \mathrm{Cr}, \mathrm{Ni}$ & & -- \\
\hline & HT -9 & moderate & $<2 \mu$ & $\mathrm{Fe}, \mathrm{Cr}, \mathrm{Ni}$ & $--_{f}^{f}$ & $--\frac{f}{f}$ \\
\hline & Ti6242 & moderate & $<2 \mu$ & $\mathrm{Fe}, \mathrm{Cr}, \mathrm{Ni}$ & $\ldots-^{\dagger}$ & $--^{\dagger}$ \\
\hline \multirow{4}{*}{${ }_{2} \mathrm{SiO}_{3}$} & 316 SS & light & $\ldots f$ & $\ldots f$ & & $\ldots f$ \\
\hline & Inconel 625 & moderate & $<2 \mu$ & $\ldots-^{f}$ & $---f$ & $---f$ \\
\hline & $H T-9$ & moderate & $<2 \mu$ & $\mathrm{Fe}, \mathrm{Cr}$ & $---f$ & $\ldots f$ \\
\hline & Ti6242 & moderate & $<\dot{\alpha} \mu$ & $--^{f}$ & $--^{f}$ & $\ldots{ }^{f}$ \\
\hline
\end{tabular}

(a) Results of analysis of the ceramic surface.

(b) Results of analysis of the alloy surface.

(c) Heavy: presence of thick scale on both surfaces (alloy and ceramic). (d) Mccicrate: some change in color; appearance of a scale.

(e) Light: little or no change; no apparent scale..

(f) Analysis in progress.

(a) Elements listed in order of approximate relative abundance. 
In two cases--HT-9 and Inconel 625--the $\mathrm{Li}_{2} \mathrm{O}$ samples had a black or dark brown coating on the surfaces in contact with the alloys. In the other two-cases--316 SS and Ti6242--the surfaces of the $\mathrm{Li}_{2} \mathrm{O}$ in contact. with the alloy turned off-white and were pitted to some extent. SEM photographs and $X$-ray spectra of the $\mathrm{Li}_{2} \mathrm{O}$ surfaces in contact with all four alloys indicated the presence of iron, nickel, and chromium (e.g., Fig. 9.5.3). This was a surprising result for the $\mathrm{Li}_{2} \mathrm{O} / \mathrm{Ti} 6242$ interface, which showed those three elements distributed evenly amongst clumps of titanium in the surface coating (Fig. 9.5.4), since all three elements are present at $<0.02 \mathrm{w} / 0$ in Ti6242. Other studies $^{1-4}$ of the compatibility of $\mathrm{Fe}-\mathrm{Ni}-\mathrm{Cr}$ alloys and $\mathrm{Li}_{2} \mathrm{O}$ at temperatures above $1073 \mathrm{~K}$ have reported the formation of volatile $\mathrm{Li}_{5} \mathrm{FeO}_{4}$ and $\mathrm{LiCrO}_{2}$. Formation of these or other vol,atile compounds may account for the presence of iron and chrome on the Ti6242 surface. (It should be noted, however, that nickel was not reported to have formed any reaction products in these earlier studies, which is contrary to some of the results in Table 9.3.2).

Each $\mathrm{Li}_{2} \mathrm{O}$ pellet tended to extrude into the circular holes and notches of the alloy samples in contact with it. Also, a scaly layer was formed at the metal/ceramic interface. Auger analysis of the 316 SS showed a thick $(>2 \mu \mathrm{m})$ uniform coating which contained mostly lithium and oxygen. The Inconel surfaces at the Incunel 625/316 s3 interfaces al 30 had a scale that contalned lithium and uxygen, which supports the speculation that some volatile reaction products were formed. The IIT-9 surface of the HT-9/Ti6242 interface was examined using the SEM. Titanium was found to be uniformly distributed over the entire surface. The mechanism of transport is most probably interfacial diffusion.

\subsubsection{Future Work}

The Ti6242 samples and pieces of the $\mathrm{Li}_{2} \mathrm{SiO}_{3}$ samples have been sent. to J. W. Davis of MDAC. All other alloys have been turned over to the ANL/MSD for detailed metallurgical analysis. Pending work on the ceramics includes SEM analysis on the remaining lithium silicate and lithium aluminate samples, as well as Auger analysis of all ceramics. Also, X-ray diffraction analysis will be performed on the surface 

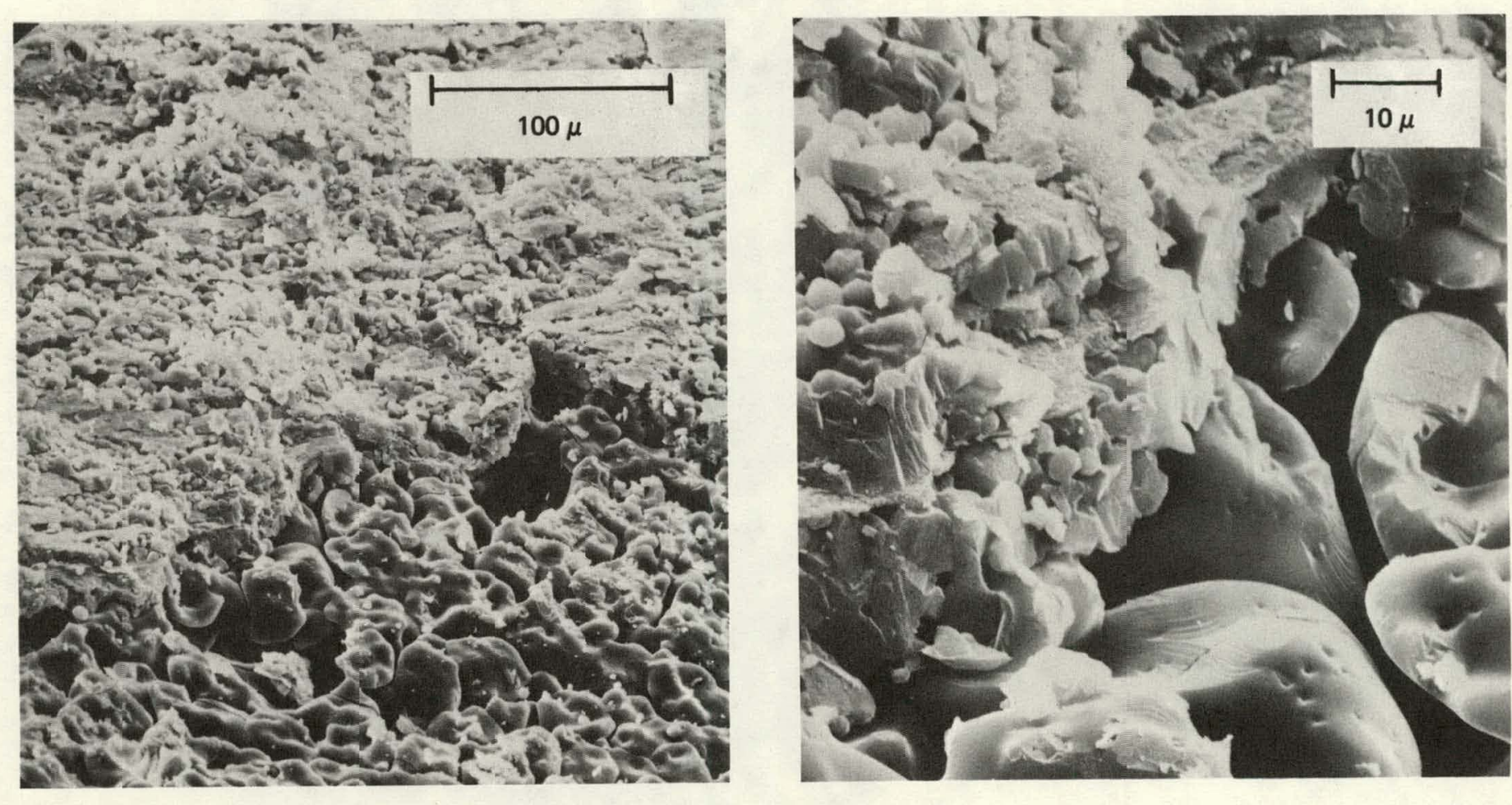

Fig. 9.5.3. Scanning Electron Micrographs of $\mathrm{Li}_{2} \mathrm{O}$ Surface Which Had Been in Contact with HT-9 for $21900 \mathrm{~h}$ at $873 \mathrm{~K}$.

(a) 300x Magnification.

(b) 1500x Magnification. 


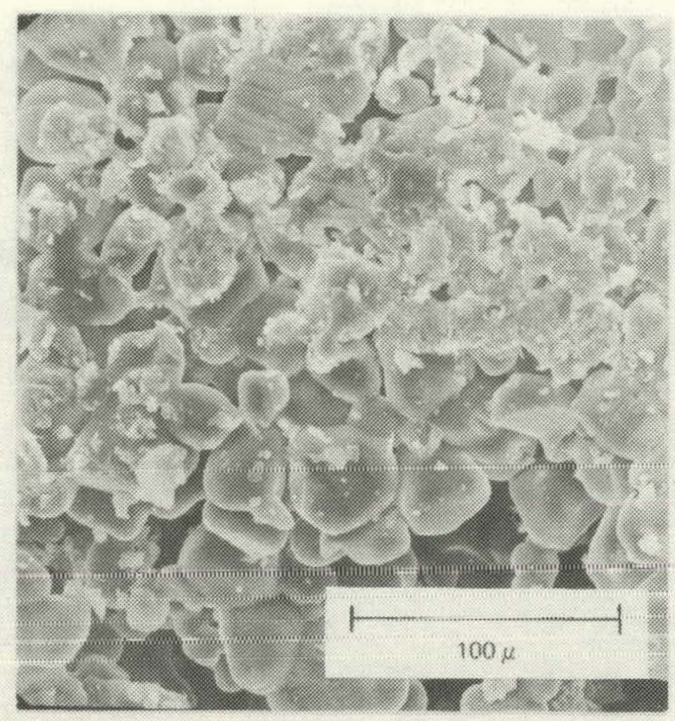

(a)

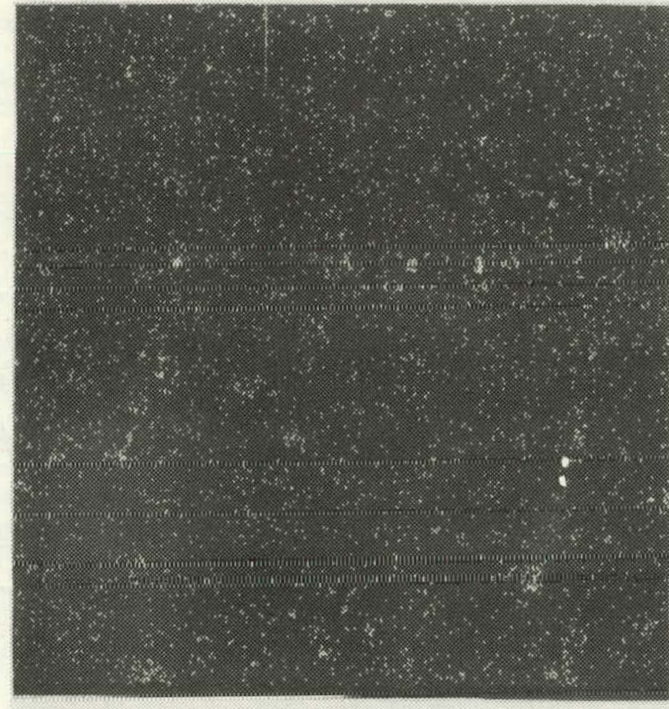

(6)

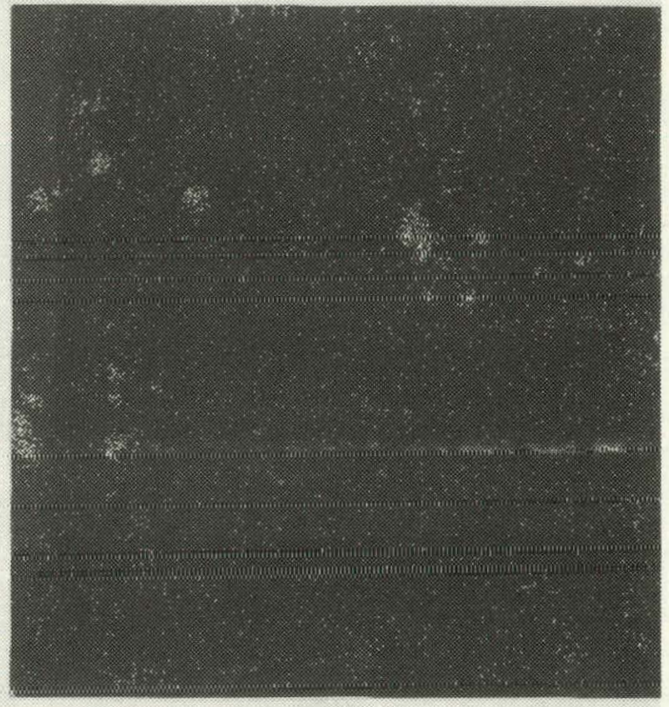

(c)

Fig. 9.5.4. (a) Scanning Electron Micrograph of $\mathrm{Li}_{2} \mathrm{O}$ Surface Which Had Been in Contact with Ti6242 for $27900 \mathrm{~h}$ at $873 \mathrm{~K}$.

(b) Iron X-Ray Scan of $\mathrm{Li}_{2} \mathrm{O}$ Surface.

(c) Titanium X-Ray Scan of $\mathrm{Li}_{2} \mathrm{O}$ Surface. 
coatings of the ceramics.

\subsubsection{Conclusions}

of the three ceramics, it appears that $\mathrm{Li}_{2} \mathrm{O}$ is the most reactive. The aluminates and silicates showed only moderate corrosivity but more work with these ceramics is warranted. Future tests should be done using methods that isolate reaction couples from one another to eliminate concerns about cross contamination. Also, reaction couples should be analyzed in cross-section without separating the metal from the ceramic, i.e., without disturbing the metal/ceramic interface.

\subsubsection{References}

1. T. Kurasawa, et al., "Reaction of Several Iron-and Nickel-Based Alloys with Sintered Li ${ }_{2} 0$ Pellets", J. Nucl. Mater. 80:48-56 (197.9).

2. H. Takeshita, et al., "Mass Spectrometric Study of the Evaporation of $\mathrm{Li}_{5} \mathrm{FeO}_{4}$ as a Corrosion Product in the Compatibility Experiment. of $\mathrm{Li}_{2} \mathrm{O}$ pellets with $\mathrm{Fe}-\mathrm{Ni}-\mathrm{Cr}$ Alloys," J. Nucl. Mater. 78:281288 (1978).

3. T. Ohmicki, et a1., "Mass Spectrometric Study of the Evaporation of $\mathrm{LiCrO}_{2}$ as a Corrosion Product in the Compatibility Experiment of $\mathrm{Li}_{2} \mathrm{O}$ Pellets with Fe-Ni-Cr Alloys", J. Nucl. Mater. 82:214-219 (1979).

4. T. Kurasawa, et al., "Compatibility between Several Heat Resistant Alloys and Sintered Li20 in Static Helium Gas Environment," J. Nucl. Mater. $91: 689-694$. 
THIS PAGE

\section{WAS INTENTIONALLY \\ LEFT BLANK}


DOE/ER-0045/4

Distribution

Category

UC-20, 20c

\section{DISTRIBUTION}

1-4. Argonne National Laboratory, 9700 South Cass Avenue, Argonne, IL . 60439
L. Greenwood
V. Maroni
D. L. Smith
H. Wiedersich

5-6. Battelle-Pacific Northwest Laboratory, P.0. Box 999, Richland, WA 99352

J. L. Brimhall

D. Dingee

7. Brookhaven National Laboratory, Upton, NY 11973

C. L. Snead, .Jr.

8. Carnegie-Mellon University, Schenley Park, Pittsburgh, PA 15213

J. C. Williams

9-204. Department of Energy, Technical Information Center, Office of Information Services, F.0. Box 62, Oak Ridge, IN 37830

For distribution as shown in TID-4500 Distribution

Category, UC-20 (Magnetic Fusion Energy), and UC-20c

(Reactor Materials)

205-210. Department of Energy, Office of Fusion Energy, Washington, DC 20545

M. M. Cohen

T. C. Reuther, Jr. (5 copies)

211. Department of Energy, Oak Ridge Operations Office, P.0. Box E, Oak Ridge, TN 37830

Office of. Assistant Manager for Energy Research and Development

212. General Atomic Company, P.0. Box 81608, San Diego, CA 92138

5. N. Roseliwassér 
213-221. Hanford Engineering Development Laboratory, P.0. Box 1970, Richland, WA 99352
H. R. Brager
D. G. Doran
F. A. Garner
D. S. Gelles
J. J. Holmes
R. E. Nygren
E. C. Opperman
R. W. Powel1
J. L. Straalsund

222-224. Lawrence Livermore Tahnratory, P.0. Box 808, T.ivetmore, in 94550
E.M.C. Dalder
M. Guinan
C. M. l.ngan

225-228. Massachusetts Institute of Technology, Cambridge, MA 02139

$$
\begin{aligned}
& \text { O. K. Harling } \\
& \text { N. J. Grant } \\
& \text { D. J. Rose } \\
& \text { V. B. Vander Sande }
\end{aligned}
$$

229-230. McDonne11 Douglas Astronautics Company, East, P.0. Box 516, St. Louis, MO 631 Kh
J. W. Davis
D. L. Kuminer

231-233. Naval Késearch Laboratory, Washington, DC . 20375

Superintendent, Materials Science and Technology Division J. A. Sprague.

H. Watgon

234-266. Oak Ridge National Laboratory, P.O. Box X, Oak Ridge, TN 37830

Central Research Library (2 copies)

Document Reference Section

Laboratury Records Department ( 2 copies)

Laboratory Records Department, RC

ORNL Patent Section

B. C. Ashdown

E. E. Bloom (10 copies)

D. N. Braski

J. H. DeVan

T. A. Gabriel 


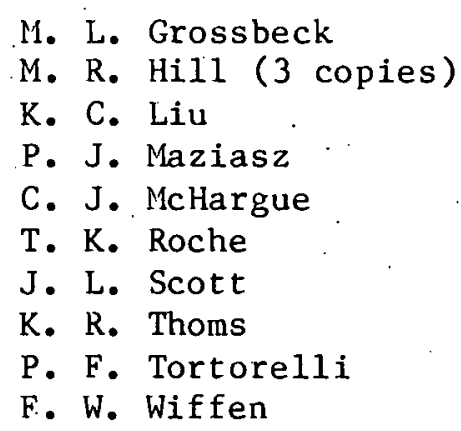

267-268. Sandia National Laboratories, Livermore Division 8316, Livermore, CA 94550

J. Swearengen

W. B̈aller

269. University of California, Department of Chemical, Nuclear, and Thermal Engineering, Los Angeles, CA 90024

R. W. Conn

270. University of California, Santa Barbara, CA 93106

G. R. Odette

271. University of Missouri, Department of Mechanical and Aerospace Engineering, Columbia, 11065211

M. Jo1les

272. University of Virginia, Department of Materials Science, Charlottesville, VA 22901

W. A. Jesser

273. University of Wisconsin, 1500 Johnson Drive, Madison, WI 53706

W. G. Wolfer

274. Westinghouse Electric Company, Fusion Power Systems Department, P.0. Box 10864, Pittsburgh, PA 15236

R. E. Guld 